UNIVERSIDADE DE SÃO PAULO - USP

FACULDADE DE ARQUITETURA E URBANISMO

MESTRADO EM PLANEJAMENTO URBANO E REGIONAL

THE MASTER PLANS AND PLANNING URBAN ON

AGGLOMERATE CUIABÁ/VÁRZEA GRANDE-MT

SILVIA MARIA NICOLETTI PILLON GARCIA

Orientadora: Dra. Marly Namur

SÃO PAULO, MARÇO DE 2010.

UNIVERSIDADE DE SÃO PAULO - USP 
FACULDADE DE ARQUITETURA E URBANISMO

MESTRADO EM PLANEJAMENTO URBANO E REGIONAL

\title{
OS PLANOS DIRETORES E O PLANEJAMENTO URBANO NO AGLOMERADO CUIABÁ / VÁRZEA GRANDE - MT
}

\author{
SILVIA MARIA NICOLETTI PILLON GARCIA
}

Dissertação apresentada ao Programa de PósGraduação da Faculdade de Arquitetura e Urbanismo (FAU) da Universidade de São Paulo (USP), como parte dos requisitos para a obtenção do Título de Mestre em Arquitetura e Urbanismo, na área de concentração Planejamento Urbano e Regional.

Orientadora: Dra . Marly Namur

SÃO PAULO, MARÇO DE 2010. 
DEDICATÓRIA

Dedico este trabalho aos meus pais, Silvia e João Ângelo, ao meu marido Luiz Fernando e a minha filha Gabriela. 


\section{AGRADECIMENTOS}

Agradeço a Deus, sem o qual nada seria possível.

Aos meus pais, Sílvia e João Ângelo pelo apoio e incentivo.

Ao meu marido Luiz Fernando pela atenção e estímulo constante.

A minha filha Gabriela pela compreensão e carinho.

A minha irmã Silvana e ao meu cunhado Cláudio, pelo suporte e atenção em São Paulo.

Aos meus sobrinhos Beatriz e André, pelo carinho e atenção.

A minha orientadora Marly Namur pelas orientações sempre firmes.

A amiga Rita de Cássia Chiletto, pelo incentivo e ajuda.

A amiga Dorcas Araújo, pelo estímulo e companheirismo.

Aos meus professores pelos preciosos ensinamentos.

Aos colegas de trabalho da Prefeitura de Várzea Grande pela colaboração e apoio.

Aos amigos e colegas que apoiaram e torceram por mim. 


\section{ÍNDICE}

Lista de Siglas viii

Lista de Ilustrações $\quad \mathrm{X}$

Lista de Quadros $\quad$ xxii

Lista de Tabelas $\quad$ xiii

Resumo xiv

Abstract $\quad \mathrm{xV}$

$\begin{array}{ll}\text { Introdução } & 016\end{array}$

$\begin{array}{ll}\text { Problemática } & 021\end{array}$

$\begin{array}{ll}\text { Justificativa } & 023\end{array}$

Objetivos 025

$\begin{array}{ll}\text { Metodologia } & 026\end{array}$

$\begin{array}{ll}\text { Capítulo } 01 \text { - Revisão bibliográfica } & 030\end{array}$

1.1- Os planos e o Planejamento Urbano no Brasil 030

1.2- O Estatuto da Cidade e a Política Urbana 039

1.2.1 - A Luta Pela Reforma Urbana 040

1.2.2- Os Princípios e Diretrizes Para o Planejamento Urbano 044

1.2.3 - Instrumentos para a Transformação Urbana 046

1.3- As Dificuldades do Planejamento Urbano no Brasil 049

Capítulo 02 - As Cidades de Cuiabá e Várzea Grande 060

2.1- Breve História de Cuiabá e Várzea Grande 060

2.2- Características dos Municípios 068

2.3- Planejamento Urbano em Cuiabá e Várzea grande 075

Capítulo 03- O Aglomerado Urbano Cuiabá - Várzea Grande 081

3.1- Criação e Estruturação 081

3.2- As Câmaras Setoriais 087

3.3- $\quad$ A Região Metropolitana do Vale do Rio Cuiabá 090 
Capítulo 04- Os Planos Diretores de Cuiabá e Várzea Grande 092

4.1- $\quad$ Os Planos Diretores após a Constituição de 1988092

4.2- O Processo de elaboração dos atuais Planos Diretores 093

4.2.1- Construção do Plano Diretor de Várzea Grande 093

4.2.2- Construção do Plano Diretor de Cuiabá 102

4.3- Características Gerais, Diretrizes e Objetivos 103

4.4- Função Social da Propriedade e da Cidade 108

4.4.1- Função Social da Propriedade e da Cidade de V. Grande 108

4.4.2- Função Social da Propriedade e da Cidade de Cuiabá $\quad 109$

Capítulo 05- Controle do Uso e Ocupação do Solo 111

5.1- Controle do Uso e Ocupação do Solo de V. Grande 111

5.2- Ações para Uso e Ocupação de Solo em V. Grande 127

5.3- Controle do Uso e Ocupação do Solo de Cuiabá 129

5.4- $\quad$ Ações Referentes ao Uso e a Ocupação do Solo em Cuiabá 137

Capítulo 06- Habitação, acesso à Terra Urbanizada e Regularização Fundiária 140

6.1- Habitação, acesso à Terra Urbanizada e Regularização Fundiária em Várzea Grande 141

6.2 Ações para Habitação, acesso à Terra Urbanizada e Regularização Fundiária em Várzea Grande $\quad 150$

6,2- Habitação, acesso à Terra Urbanizada e Regularização Fundiária em Cuiabá 151

6.4- Ações para Habitação, acesso à Terra Urbanizada e Regularização Fundiária em Cuiabá

Capítulo 07- Mobilidade Urbana 159

7.1- Mobilidade Urbana em Várzea Grande 162

7.2- Ações para a Mobilidade Urbana em Várzea Grande 166

7.2- $\quad$ Mobilidade Urbana em Cuiabá 167

7.4- $\quad$ Ações para a Mobilidade Urbana em Cuiabá 170

Capítulo 08- Saneamento Ambiental e Meio Ambiente 205

8.1- Saneamento Ambiental em Várzea Grande 205 
8.2- Ações para o Saneamento Ambiental em Várzea Grande 208

8.3- Saneamento Ambiental em Cuiabá 209

8.4- Ações para o Saneamento Ambiental em Cuiabá 212

8.5- Meio Ambiente em Várzea Grande 213

8.6- Ações para o Meio Ambiente em Várzea Grande 219

8.7- $\quad$ Meio Ambiente em Cuiabá 220

8.8- Ações para o Meio Ambiente em Cuiabá 222

Capítulo 09- Estrutura Administrativa e Controle Social 225

9.1- Estrutura Administrativa e Controle Social de Várzea Grande 226

9.2- Estrutura Administrativa e Controle Social de Cuiabá 233

9.4- Diretrizes para o Aglomerado Urbano e Região 242

Capítulo 10- Conclusão do Trabalho 244

10.1- Conclusão 244

10.2- Bibliografia 256 


\section{LISTA DE SIGLAS}

IBGE - Instituto Brasileiro de Geografia e Estatística

IPDU - Instituto de Pesquisa e Desenvolvimento Urbano

SERFAU - Serviço Federal de Habitação e Urbanismo

PLI - Planos de Desenvolvimento Locais Integrados

BNH - Banco Nacional de Habitação

FIPLAN - Fundo de Financiamento para o Planejamento Local

PAC - Programa de Ação Concentrada

PND - Plano Nacional de Desenvolvimento

ONU - Organização das Nações Unidas

BID - Banco Internacional de Desenvolvimento

FMI - Fundo Monetário Internacional

EIV - Estudo de Impacto de Vizinhança

IPTU - Imposto Predial e Territorial Urbano

COHAB - Companhia de Habitação Popular do Estado de Mato Grosso

PDLI - Plano de Desenvolvimento Local Integrado

AGLURB - Aglomerado Urbano (Cuiabá/Várzea grande)

IAB - Instituto Brasileiro de Arquitetos

SINDUSCOM - Sindicato dos Trabalhadores da Construção Civil

CREA/MT - Conselho Regional de Arquitetura, Engenharia e Agronomia

CMDU - Conselho Municipal de Desenvolvimento Urbano

SMDU - Sistema Municipal de Desenvolvimento Urbano

OGU - Orçamento Geral da União

SEPLAN - Secretaria de Planejamento

PPA - Plano Plurianual

LDO - Lei de Diretrizes Orçamentária

LOA - Lei de Orçamento anual

SEJUSP - Secretaria de Justiça e Proteção à Pessoa

CIOSP - Centro Integrado de Ocorrências de Segurança Pública

UFMT - Universidade Federal de Mato Grosso

HBB - Habitar Brasil BID

UNIVAB - União Várzeagrandense de Associações de Moradores de Bairro PDM - Plano Diretor Municipal 
FMDU - Fundo Municipal de Desenvolvimento Urbano

ZEIS - Zonas Especiais de Interesse social

PDDE - Plano Diretor de Desenvolvimento Estratégico

PDP - Plano Diretor Participativo

INCRA - Instituto Nacional de Desenvolvimento Rural e Agrário

EIA - Estudo de Impacto ambiental

CURA - Comunidade Urbana para Recuperação Acelerada

SMTU - Superintendência Municipal de Transporte e Transito

CPA - Centro Político Administrativo

DETRAN - Departamento de Transito

DNIT - Departamento Nacional Transporte

INPE - Instituto Nacional de Pesquisa

SMTU - Secretaria Municipal de Transportes Urbanos

EMEB - Escola Municipal de Ensino Básico

PAC - Programa de Aceleração do Crescimento

EMPAER - Empresa Matogrossense de Pesquisa, Assistência e Extensão Rural

APP - Áreas de Preservação Permanente

DNPM - Departamento Nacional de Produção Mineral

JUVAM - Juizado Volante de Apoio ao Meio Ambiente

SEMA - Secretaria de Meio Ambiente do Estado de Mato Grosso

COMDEMA - Conselho Municipal de Defesa do Meio Ambiente

CONCIDADE - VG - Conselho da Cidade de Várzea Grande

SMDU - Sistema Municipal de Desenvolvimento Urbano

CMDE - Conselho Municipal de Desenvolvimento E

FETAB - Fundo Estadual de Transporte e Habitação 


\section{LISTA DE ILUSTRAÇÕES}

Figura 01 - Localização de Cuiabá em relação ao Brasil 060

Figura 02 - Desenho ilustrativo de Cuiabá por volta de 1730.

Figura 03 - Cuiabá na época da guerra do Paraguai (em torno de 1864). 063

Figura 04 - Esboço de Cuiabá na década de 1970066

$\begin{array}{ll}\text { Figura } 05 \text { - Evolução Urbana de Cuiabá } & 069\end{array}$

$\begin{array}{ll}\text { Figura } 06 \text { - Evolução Urbana de Várzea Grande } & 070\end{array}$

$\begin{array}{ll}\text { Figura } 07 \text { - Classe de Renda em Cuiabá } & 072\end{array}$

Figura 08 - Densidade Demográfica de Várzea Grande 073

$\begin{array}{ll}\text { Figura } 09 \text { - Densidade Demográfica de Cuiabá } & 074\end{array}$

Figura 10 - AGLURB (Aglomerado Urbano Cuiabá Várzea Grande) 085

Figura 11 - Contexto Regional 086

Figura 12 - Condicionantes para Definição das Áreas de Aplicação

$\begin{array}{ll}\text { dos Índices Urbanísticos } & 118\end{array}$

Figura 13 - Áreas Passíveis de Aplicação dos Instrumentos do

$\begin{array}{ll}\text { Estatuto da Cidade } & 119\end{array}$

Figura 14 - Zoneamento de Várzea Grande $\quad 120$

Figura 15 - Índices Urbanísticos de V. Grande 121

Figura 16 - Áreas Prioritárias para Aplicação de ZEIS em Várzea Grande 122

Figura 17 - Uso e Ocupação do solo de Cuiabá 132

$\begin{array}{ll}\text { Figura } 18 \text { - Hierarquia Viária de Cuiabá } & 160\end{array}$

Figura 19 - Hierarquia Viária de Várzea Grande 161

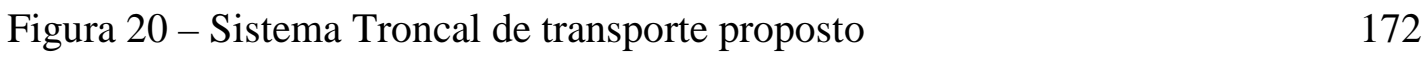

$\begin{array}{ll}\text { Figura } 21 \text { - Localização dos terminais } & 173\end{array}$

$\begin{array}{ll}\text { Figura } 22 \text { - Alimentadoras do terminal Coxipó } & 174\end{array}$

$\begin{array}{ll}\text { Figura } 23 \text { - Alimentadoras do terminal Carumbé } & 176\end{array}$

$\begin{array}{ll}\text { Figura } 24 \text { - Alimentadoras do terminal CPA } & 177\end{array}$

$\begin{array}{ll}\text { Figura } 25 \text { - Alimentadoras do terminal Monte Líbano } & 178\end{array}$

$\begin{array}{ll}\text { Figura 26- Alimentadoras do terminal do Porto } & 179\end{array}$

$\begin{array}{ll}\text { Figura } 27 \text { - Modelo dos terminais que serão construídos } & 180\end{array}$

Figura 28 - Adequação viária avenidas República do Líbano 183

Figura 29 - Construção de viaduto no trevo do Bairro Santa Rosa 184

Figura 30 - Construção de viaduto no trevo da ponte do rio Coxipó 185 
Figura 31 - Construção da $3^{\mathrm{a}}$ pista da Av. Fernando Correa 185

Figura 32 - Duplicação Av Archimedes P. Lima 186

$\begin{array}{ll}\text { Figura } 33 \text { - Av. Parque Gumitá } & 186\end{array}$

Figura 34 - Ligação entre a MT 010 ao Ribeirão do Lipa 187

Figura 35 - Ligação Fundos do Pantanal Shopping e a Av. Dante de Oliveira 187

Figura 36- Construção de trincheiras no complexo da Av. Miguel Sutil 187

$\begin{array}{ll}\text { Figura } 37 \text { - Conclusão da estrada do Coxipó } & 188\end{array}$

Figura 38 - Binário das Avenidas Trabalhadores e Gonçalo Antunes 188

Figura 39 - Construção da Av. Beira Rio Norte 189

$\begin{array}{ll}\text { Figura } 40 \text { - Binário do B. Tijucal } & 190\end{array}$

$\begin{array}{ll}\text { Figura } 41 \text { - Pavimentação B. Pedra } 90 & 190\end{array}$

Figura 42 - Av. Beira Rio até a Av. Palmiro Paes de Barros 191

Figura 43 - Construção de Ponte sobre o rio Coxipó 192

Figura 44 - Rotatória do Cruzamento da Av. Miguel Sutil com Av. C. Campos 192

Figura 45 - Rotatória e Prolongamento da R. Ramiro de Noronha até a R. Seror 193

Figura 46 - Av. Parque Gumitá 193

Figura 47 - Viaduto sobre a Av. Fernando Corrêa (Shopping 3 Américas) 194

Figura 48 - Duplicação Av. Dante de Oliveira 194

Figura 49 - Ligação da Av. Fernando Corrêa da Costa até Av. Archimedes Lima 195

Figura 50 - Ligação entre os bairros Despraiado e Jd. Ubirajara 196

Figura 51 - Binário na Ligação da Av. R. de Mendonça a Rod. 251

Figura 52 - Duplicação da Av. Antártica até o Rodoanel 197

Figura 53 - Prolongamento da Avenida Brasil até bairro $1^{\circ}$ de Março 198

$\begin{array}{ll}\text { Figura } 54 \text { - Conclusão da Rua Itaparica } & 198\end{array}$

Figura 55 - Av. Miguel Sutil com R. Afonso Pena (construção de viaduto) 199

Figura 56 - Pavimentação das ruas Armando Candia, e Tereza Lobo 200

Figura 57 - Ligação entre os bairros Alto da Boa Vista e Senhor dos Passos 200

Figura 58 - Pavimentação da estrada do Ribeirão Ligando a Av. Afonso Pena 201

Figura 59 - Complementação da Avenida Mário Palma 202

Figura 60 - Ligação da Avenida Rubens de Mendonça a Avenida Brasil 222

Figura 61 - Organograma da Prefeitura de Várzea Grande (2008) 227

Figura 62- Organograma da prefeitura de Cuiabá (2008) 234 


\section{LISTA DE QUADROS}

Quadro 01 - Porcentagem de população urbana no Brasil 017

Quadro 02 - Evolução da população em Cuiabá e Várzea Grande. 023

Quadro 03 - Rendimento em Cuiabá e Várzea Grande 071

$\begin{array}{ll}\text { Quadro } 04 \text { - Parâmetros de uso e ocupação do solo. } & 115\end{array}$

$\begin{array}{ll}\text { Quadro } 05 \text { - Ocupação do solo urbano } & 130\end{array}$

$\begin{array}{ll}\text { Quadro } 06 \text { - Programas habitacionais de Várzea Grande } & 143\end{array}$

$\begin{array}{ll}\text { Quadro } 07 \text { - Programas Habitacionais de Cuiabá } & 151\end{array}$

$\begin{array}{ll}\text { Quadro } 08 \text { - Frota de Veículos de Cuiabá } & 171\end{array}$

Quadro 09 - Alimentadoras e intervenções do terminal Coxipó 173

Quadro 10 - Alimentadoras e intervenções do terminal Carumbé 175

Quadro 11 - Alimentadoras e intervenções do terminal CPA 176

$\begin{array}{ll}\text { Quadro } 12 \text { - Alimentadoras e intervenções do terminal CPA } & 177\end{array}$

Quadro 13 - Alimentadoras e intervenções do terminal do Porto 178

Quadro 14 - Localidades Projeto Bairro Cidadão 208

Quadro 15 - Extração Mineral em V. Grande 215 


\section{LISTA DE TABELAS}

Tabela 1 - Evolução da população. Fonte IBGE 2000 e 2007068

Tabela 2 - Zoneamento de Várzea Grande Fonte: Plano Diretor de $2007 \quad 118$

Tabela 03 - Classificação dos usos de Várzea Grande 117

Tabela 04 - Parâmetros de uso e ocupação do solo de Várzea Grande I 146

Tabela 05 - Parâmetros de uso e ocupação do solo de Várzea Grande 147

Tabela 06 - Classificação hierárquica e dimensionamento das vias $\quad 164$

Tabela 07 - Dimensão do sistema viário para loteamentos populares de Cuiabá 170 


\section{RESUMO}

Os Planos Diretores têm recebido muitas críticas devido a sua ineficácia como instrumento de planejamento urbano no Brasil e por certo período ficaram em segundo plano. Com a promulgação da Lei 10.257 de 2001, chamado Estatuto da Cidade, os municípios foram obrigados a rever seus Planos Diretores para adaptá-los aos novos princípios e objetivos dessa Lei.

Neste trabalho foram avaliados os Planos Diretores das cidades do Aglomerado Urbano Cuiabá e Várzea Grande - Mato Grosso/Brasil. Os estudos foram a partir da realidade das cidades, das suas estruturas administrativas e do fato delas formarem um Aglomerado Urbano (atualmente Região Metropolitana do Vale do Rio Cuiabá) exigindo que muitos assuntos fossem tratados em harmonia.

Foi abordado o planejamento urbano no Brasil; a história e as características de Cuiabá e Várzea Grande; a formação do Aglomerado Urbano Cuiabá Várzea Grande; a elaboração dos atuais Planos Diretores; a utilização dos instrumentos disponíveis no Estatuto da Cidade; as diretrizes para as políticas de acesso a terra urbanizada; a regularização fundiária; o saneamento ambiental; o meio ambiente e a mobilidade urbana; e as principais ações que estão sendo realizadas segundo os Planos Diretores.

Palavras-chave: Planejamento Urbano; Plano Diretor; Aglomerado Urbano 


\begin{abstract}
The master plans have received much criticism due to their effectiveness as urban planning instrument in Brazil and by certain period were in the background. With the enactment of law 10.257/2002, called City Status, the municipalities were forced to revise their plans directors to adapt them to new principles and objectives of the law.

This work have been assessed the master plans of cities and urban Cuiabá Várzea Grande - Mato Grosso - Brazil, from the study of cities, the administrative structure and form an urban cluster (currently metropolitan region Cuiabá River Valley) and many matters to be dealt with in harmony.

Was approached the urban planning and examined the history and characteristics of Cuiabá and Várzea Grande; the urban cluster of Cuiabá - Várzea Grande shavings urban, the current master plans; the use of instruments available in the city's status; guidelines for land access policies; land regularization urbanized; environmental sanitation; the environment and urban mobility; the administrative structure of cities and the main actions that are being carried out in accordance with the master plans.
\end{abstract}

Keywords: Urban Planning, Plan Director, Urban Agglomerated 


\section{INTRODUÇÃO}

Esta dissertação objetiva analisar os Planos Diretores de Cuiabá e Várzea Grande elaborados após a promulgação da Lei 10.257/2001, denominada Estatuto da Cidade, observando a utilização dos instrumentos que possibilitam o desenvolvimento e o controle urbanístico, o acesso à habitação e à terra urbanizada, assim como as principais ações desenvolvidas para a implementação dos Planos Diretores. Será considerado o fato de Cuiabá e Várzea Grande serem cidades conurbadas que faziam parte até 2009 de um aglomerado urbano, transformado atualmente na Região Metropolitana do Vale do Rio Cuiabá.

Até o início do século XX a rede urbana era pouco significativa no Brasil, a não ser pela importância que adquiria em seu relacionamento com o comércio exterior, o que refletia nitidamente o caráter explorador colonial-econômico. Segundo LODDER (1978; pág. 5) sua finalidade era: “(...) ocupar, dominar e extrair o máximo da região em que estava."

O Brasil passou por intensa transformação no cenário urbano ao longo do século $\mathrm{XX}$, e a população que no início do século era predominantemente rural, passou a ser predominantemente urbana como demonstra o quadro 01

Quadro 01 - Porcentagem da população urbana no Brasil

\begin{tabular}{|l|l|}
\hline ANO & \% POPULAÇÃO URBANA \\
\hline 1900 & 9,40 \\
\hline 1920 & 10,70 \\
\hline 1940 & 31,24 \\
\hline 1950 & 36,16 \\
\hline 1960 & 44,93 \\
\hline 1970 & 55,92 \\
\hline 1980 & 67,59 \\
\hline 1990 & 75,59 \\
\hline 2000 & 81,23 \\
\hline
\end{tabular}

Fonte IBGE - Organizado por Oliveira (2001)

.O crescimento urbano foi marcado por características concentradoras, tendo em vista que as Regiões Sudeste e - ainda que de forma menos intensa - a Região Sul, concentraram o maior contingente populacional de forma mais vigorosa em suas 
capitais recebendo a maior parte de recursos governamentais para provê-las de infraestrutura. A industrialização e as condições tecnológicas da produção concentraram os instrumentos, a energia e a mão de obra nestes centros (principalmente São Paulo e Rio de Janeiro), e atraíram grandes correntes migratórias provenientes de regiões, onde havia escassez de infra-estrutura para a produção e, consequentemente, de empregos (um exemplo são as correntes migratórias que vinham do nordeste com destino a São Paulo e Rio de Janeiro). LODDER (1978).

Na virada do milênio o Brasil se apresentava com $81,2 \%$ da população vivendo nas cidades - segundo o IBGE (2000) - sem, contudo, ter ampliado a oferta de infraestrutura para acomodar a numerosa população carente, que ao longo do tempo buscou oportunidades melhores junto aos grandes centros urbanos. A ineficácia ou até a falta de políticas públicas para proporcionar condições melhores para esta população fez surgir as periferias carentes. As periferias das cidades grandes e médias se tornaram locais desprovidos de serviços básicos e condições dignas de moradias: favelas, invasões, violência, degradação ambiental, falta de oportunidades, falta de água, luz, esgoto e acessibilidade têm sido o diagnóstico destes lugares. Nas cidades brasileiras pode-se perceber claramente a segregação dos mais humildes, para quem o poder público sempre reservou as piores localizações na cidade.

O poder público optou por investir em infra-estrutura para a produção industrial de massa e no setor terciário. Suas políticas e sua legislação sempre foram voltadas à cidade legal $^{1}$, feita para as classes mais favorecidas, e por outro lado, constatou-se o desprezo pela parte chamada de cidade real $^{2}$, que trata da realidade de milhares de pessoas que se encontram à margem das ações do Estado. As práticas arcaicas de gestão urbana resultaram em baixa oferta de serviços públicos com a qualidade esperada. Degradação ambiental, sérios problemas de transporte e circulação viária, além dos inúmeros problemas fundiários e a falta de moradia adequada, tudo isso contribui para o

\footnotetext{
${ }^{1}$ Cidade legal é um termo utilizado por Raquel Rolnik para se referir à parte da cidade onde existe infraestrutura adequada, onde as leis urbanísticas são cobradas pela prefeitura e respeitadas pelos moradores e as residências possuem escritura pública, registrada em cartório como manda o Código Civil.

${ }^{2}$ Cidade real é uma expressão utilizada por Raquel Rolnik para se referir às desigualdades presentes nas cidades brasileiras, onde se pode observar que em parte da cidade existe urbanização adequada, serviços e benfeitorias, as leis urbanísticas são aplicadas e fiscalizadas e as camadas sociais que a habitam podem pagar o preço de um edifício - comercial ou residencial - devidamente regularizado perante a lei, por outro lado, a outra parte - geralmente a periferia - convive com a falta de serviços públicos, de infraestrutura urbana, de locais para lazer e problemas ambientais. Nesta parcela da cidade, as autoridades municipais raramente cobram dos habitantes o rigor da legislação urbanística, e, é comum a existência de terrenos "grilados" em situação de posse, sem escritura e com diversas outras irregularidades que trazem insegurança para a população. Este contraste muitas vezes ignorado pelo Poder Municipal, é o que vem sendo chamado de cidade real.
} 
mais grave: a degradação social, trazendo em seu bojo altos índices de violência urbana a falta de oportunidade para os mais carentes e a péssima qualidade de vida de um grande contingente de pessoas.

Outra preocupação do Estado nos anos 1950 e 1960, no âmbito do planejamento regional do país, foram as desigualdades regionais. Nesta época a estagnação no processo de absorção da mão de obra nos centros já bastante industrializados do sudeste, e por outro lado, a transferência da capital do país para Brasília na década de 1950 fez com que o Governo Federal promovesse, através de obras de infra-estrutura e uma série de incentivos, a intensificação do povoamento do interior.

No caso de Mato Grosso, observa-se que desde 1930, existiam esforços do Governo Federal para sua colonização. O programa "Marcha para o Oeste" trouxe as primeiras transformações urbanísticas para a capital, Cuiabá, e consolidou o interesse por transformá-la em pólo regional. O processo de integração nacional, no entanto, só decolou verdadeiramente e começaram a aparecer resultados significativos a partir de 1960, momento que além da extração de ouro pedras preciosas, madeira e da agropecuária nos moldes extensivos que dominavam até então sua economia, recebeu investimentos maciços por parte do Estado para que, a partir das novas tecnologias levadas à produção agrícola, atingisse um aumento extraordinário na produtividade das terras do cerrado (considerada até então muito baixa). (IPDU CUIABÁ)

Esta nova realidade e a vontade do Governo Federal de abrir novas fronteiras de desenvolvimento no país provocaram a abertura e melhoria de estradas, em conformidade com o lema do governo militar vigente na época, "integrar para não entregar". Houve a promoção e incentivos para inúmeros assentamentos rurais, investimentos no setor energético, oferta de crédito para a agricultura e a pecuária, e ainda a implantação do distrito industrial de Cuiabá (na época o governo incentivou a implantação de vários distritos industriais em cidades de porte médio estrategicamente localizadas no Brasil), preparando-a para os novos tempos de prosperidade. Mato Grosso durante a década de 1970 se transformou em um imenso canteiro de obras atraindo pessoas de todas as partes do Brasil em busca de oportunidades. (IPDU CUIABÁ)

Em 1977, o Estado de Mato Grosso foi dividido, dando origem ao Estado de Mato Grosso do Sul (cuja capital é Campo Grande). Ao contrário do que se previa, Mato Grosso teve seu desenvolvimento acelerado, especialmente na porção norte e 
central, com o surgimento e crescimento de cidades como Alta Floresta, Sinop, Sorriso, Tangará da Serra e tantas outras.

O Estado atualmente não conta com o mesmo crescimento assustador das décadas de 1960 até 1980, porém seu crescimento e desenvolvimento estão acima da média nacional, e sua vocação agro-pecuária se consolidou ao lado do crescimento de seu parque industrial, fazendo do agro-negócio seu ponto forte.

Cuiabá, como capital do Estado de Mato Grosso, não estava estruturada para receber tamanho contingente, e os problemas urbanos sofridos pelas grandes cidades surgiram, e se agravaram de forma rápida. Durante a década de 1970, era difícil encontrar habitação disponível, tanto na capital, como na vizinha, Várzea Grande. Faltava tudo, desde infra-estrutura (água, luz, pavimentação...), equipamentos públicos e serviços (escolas, hospitais, creches). As pessoas, especialmente as mais humildes, se instalaram em loteamentos clandestinos, em áreas "griladas", em áreas de preservação permanente e em terras públicas.

Cuiabá e Várzea Grande são cidades conurbadas separadas apenas pelo Rio Cuiabá. Tendo em vista que apresentam os mesmos problemas dos aglomerados urbanos e regiões metropolitanas das demais centralidades do Brasil, ou seja: a heterogeneidade, fragmentação, e hierarquização dos espaços no tecido urbano, as periferias concentrando a pobreza e a falta de serviços e infraestrutura, a concentração de serviços mais qualificados na cidade pólo e a dificuldade de planejamento em comum. Desta forma há a necessidade de planejar alguns setores conjuntamente.

No aglomerado urbano de Cuiabá e Várzea Grande, observa-se que os problemas urbanos não foram solucionados ainda, especialmente as questões fundiárias (habitações produzidas fora do mercado formal e em condições precárias, sem documentação e condições dignas de abrigar uma família), a violência, a falta de esgoto, água potável e pavimentação, ao lado das questões de saúde, emprego e renda, transporte e infra-estrutura viária são desafios a serem superados.

Com a promulgação do Estatuto das Cidades, novos canais de discussão com a sociedade, e novas formas da condução dos assuntos relacionados ao contexto urbano (e também rural) deverão ser adotados pelas cidades. Seus princípios e objetivos representam esperanças de mudanças no panorama dos municípios. Porém ainda se espera por uma política mais consistente para as aglomerações urbanas e regiões metropolitanas. 
O Estatuto da Cidade obrigou muitos municípios à revisão de seus Planos Diretores para incorporar seus princípios e objetivos, de forma que Cuiabá e Várzea Grande também o fizeram. Com a exigência da participação popular no processo de planejamento urbano, novos horizontes se abrem para a gestão urbana e possibilidades para a conquista da sonhada cidade com urbanização e qualidade de vida para todos.

No final deste trabalho algumas questões deverão ser respondidas:

- Os Planos Diretores elaborados pelos Municípios adotaram os princípios e os instrumentos do Estatuto da Cidade de forma harmônica, levando em conta que são municípios conurbados?

- Os Planos Diretores foram elaborados levando em conta a realidade das cidades?

- Os Planos estão sendo implementados (as ações desenvolvidas fazem parte dos Planos)?

- Tem existido diálogo, planejamento e ações em nível metropolitano?

Para responder os questionamentos acima formulados, este trabalho se dividirá em dez capítulos.

O capítulo 1 destinou-se à revisão bibliográfica, onde serão estudados os planos e o planejamento urbano no Brasil; o Estatuto da Cidade e a política urbana; e as dificuldades do planejamento urbano no Brasil.

O Capítulo 2 foi dedicado às Cidades de Cuiabá e Várzea Grande, suas histórias, características e o planejamento urbano nelas realizado.

O Capítulo 3 tratou do Aglomerado Urbano Cuiabá - Várzea Grande, discorrendo sobre a Criação, estruturação, o funcionamento das Câmaras Setoriais e a formação da Região Metropolitana do Vale do Rio Cuiabá.

O Capítulo 4 traz estudados e análises dos Planos Diretores de Cuiabá e Várzea Grande, os planos de 1994 que antecederam os atuais, o processo de elaboração, as características gerais, diretrizes, objetivos, e a função social da cidade neles contida.

O Capítulo 5 fala do controle do uso e ocupação do solo em Cuiabá e Várzea Grande e as ações que estão sendo desenvolvidas nas localidades.

O Capítulo 6 trata de habitação, acesso à terra urbanizada e regularização fundiária, e as ações para implementar os planos neste setor.

O Capítulo 7 apresenta os estudos sobre a mobilidade urbana nos planos e as ações desenvolvidas nas cidades. 
O Capítulo 8 se destina ao Saneamento Ambiental e Meio Ambiente e as ações desenvolvidas neste setor.

O Capítulo 9 apresenta a Estrutura Administrativa, o controle social e as ações destinadas ao setor.

O Capítulo 10 é dedicado à conclusão do trabalho e à Bibliografia.

\section{PROBLEMÁTICA}

A Constituição de 1988 tratou pela primeira vez na história das nossas Constituições da política urbana, tendo sido sensível aos apelos da sociedade que já não suporta os problemas urbanos que se avolumam principalmente nas grandes e médias cidades. A principal preocupação foi a questão fundiária e a função social da cidade. Porém, a esperança de transformação urbana somente veio com a regulamentação deste capítulo pela Lei 10.257, o denominado Estatuto da Cidade.

O Estatuto da Cidade estabeleceu que os municípios fizessem (ou revissem) seus planos diretores, para que fossem construídos com a participação de toda a sociedade e se ajustassem às novas determinações legais, incorporando em sua legislação uma série de instrumentos disponibilizados para melhor prover as cidades de meios para seu controle e gestão.

O fato de o Brasil ser um país de território continental faz com que cada região, cada Estado e, cada município tenha uma característica própria, devida às peculiaridades históricas, sociais, políticas, econômicas e territoriais que estão inseridos. Portanto, o problema está na maneira com que cada cidade aplicará os instrumentos urbanísticos para o controle e a gestão urbana, já que o Estatuto da Cidade diz que é no plano diretor de cada município que se determinará qual a função social da cidade. Em outras palavras, qual a cidade desejada pela população? Para tanto, os municípios contam com inúmeros instrumentos, (tanto os novos como os antigos, que mesmo fora do Estatuto, se fazem presentes no ordenamento jurídico do país) que deverão ser moldados para as necessidades de cada um, conforme a realidade vivida e as aspirações dos munícipes.

Não obstante a importância do processo de elaboração dos planos diretores nos municípios, nada adiantará se a lei não sair do papel e não for realmente aplicada. Para tanto, os municípios precisam estar fortalecidos administrativamente (ou se 
fortalecerem), propiciando um processo de planejamento urbano contínuo e democrático, transformando a lei do plano diretor em ações.

Esta tarefa será especialmente árdua para os municípios sem tradição de planejamento urbano, sem estrutura adequada e sem recursos financeiros para elaborarem e colocarem em prática os planos diretores.

Os municípios integrantes de regiões metropolitanas e aglomerados urbanos enfrentaram ainda outros problemas referentes à compatibilidade das intenções previstas nas legislações, no que tange os assuntos referentes às questões comuns, cujas ações em um poderá causar transtornos para o outro, tendo em vista a autonomia municipal para fazer leis e promover políticas segundo seu interesse individual. Nestas localidades, a falta de bom senso, de diálogo, de negociação e de mediação para se costurar acordos e pactos, poderá ser desastrosa para a população do local, pois as dificuldades aumentarão se prevalecer legislação e ações conflituosas.

As cidades de Cuiabá e de Várzea Grande - MT são exemplos de municípios que têm vivido esta problemática, pois durante as décadas de 1960 e 1970, estas cidades receberam um elevado número de migrantes que chegavam atraídos pelos programas de desenvolvimento que eram implantados no Centro Oeste e pela imensa quantidade de obras realizadas pelo governo. No entanto, conseguiram acompanhar o ritmo de crescimento e passaram a conviver com vários problemas, especialmente a falta de moradia (que resultou em vários loteamentos clandestinos e terras griladas na periferia), a falta de infra-estrutura (água, luz, pavimentação...), a insuficiência de equipamentos públicos (escolas, creches, hospitais) e outros tantos problemas que até hoje não foram devidamente solucionados, e sim agravados.

Além de Cuiabá e Várzea Grande contar com todos os problemas urbanos que desafiam a gestão e o planejamento das cidades brasileiras, por serem vizinhas e sofrerem um intenso processo de conurbação (só o Rio Cuiabá as separa), muitas ações praticadas em uma, interfere na outra, e muitos problemas são comuns. É assim com a questão do transporte coletivo e da mobilidade urbana, com a utilização do rio Cuiabá (para lazer, turismo e extração de areia e argila, e ainda a poluição), com o tratamento de esgoto e resíduos sólidos, a problemática da violência e segurança pública, da continuidade da malha viária, do abastecimento, do meio ambiente e tantas outras questões que dizem respeito a ambas, que se não tratadas harmoniosamente, agravarão os problemas já existentes, e piorarão as condições de vida do aglomerado em questão. 
Quadro 02 - Evolução da população em Cuiabá e Várzea Grande.

\begin{tabular}{|l|l|l|l|}
\hline Ano / Localidade & Cuiabá & Várzea Grande & $\begin{array}{l}\text { Aglomerado } \\
\text { Urbano }\end{array}$ \\
\hline 1950 & 56.204 & 5.503 & 61.707 \\
\hline 1960 & 57.860 & 11.044 & 68.904 \\
\hline 1970 & 100.860 & 18.146 & 119.011 \\
\hline 1980 & 212.984 & 76.676 & 289.660 \\
\hline 1990 & 380.140 & 151.314 & 531.454 \\
\hline 2000 & 483.346 & 215298 & 698.644 \\
\hline 2007 & 526.830 & 230.307 & 757.137 \\
\hline
\end{tabular}

Fonte IBGE 2000 e 2007.

Outros desafios se apresentam não apenas no momento de revisão (ou elaboração) dos planos diretores, mas principalmente no momento de colocá-los em prática em várias cidades, devido ao perfil da sociedade local (muitas vezes patrimonialista e clientelista), a forma de se administrar as cidades (de maneira autoritária e arcaica), e outros entraves políticos e sociais, que entre outras questões, desafiam há muito tempo a eficácia do planejamento urbano no Brasil.

\section{JUSTIFICATIVA}

As questões urbanas revestem-se de grande complexidade: o gerenciamento, o planejamento, e todos os assuntos a ela pertinentes, tornaram-se relevantes para toda a população do município (urbana e rural). Lidar com todas as nuances que envolvem tanto o planejamento como a gestão urbana, e até mesmo as questões que extrapolam seus contornos abrangendo toda uma região, têm se tornado um dos grandes desafios da atualidade, requerendo esforços interdisciplinares por parte do Estado dos estudiosos, dos técnicos e de toda a população.

A Constituição Federal de 1988 instituiu no seu artigo 23 uma série de competências comuns entre os entes da federação, e no artigo 30 estabeleceu o que é de competência dos municípios. Ainda tratou pela primeira vez das questões de política urbana, abrigando em seus artigos 182 e 183 as diretrizes gerais, dentre as quais estão a função social da cidade e da propriedade, o plano diretor como lei básica da política de desenvolvimento e expansão urbana, e atribui a execução desta política ao poder 
municipal. O texto constitucional, somado ao Estatuto da Cidade deixa clara a responsabilidade do município com uma imensidão de assuntos que dizem respeito ao dia a dia do cidadão, sendo que o poder público local pode ser decisivo na qualidade de vida da população, tendo em vista que este é o nível de poder mais próximo da população. Quando o povo precisa de serviços públicos, vai cobrar ações e reclamar dos problemas na prefeitura municipal. Cabe conhecer como o poder público de cada local tem se organizado para esta tarefa tão complexa que é o gerenciamento de uma cidade, tendo em vista que cada cidade é única, ao mesmo tempo em que apresentam semelhanças.

Ao plano diretor municipal de cada cidade caberá dizer qual é a sua função social, a partir da vontade popular, que deverá estar presente em todas as etapas de elaboração ou revisão desta lei, assim como na sua execução, garantindo à população acesso à gestão urbana de forma democrática. Os planos diretores municipais irão dizer qual é a cidade desejada por sua população, sendo então o ponto de partida para o planejamento e as ações sobre a cidade.

O conhecimento da forma como cada local tem realizado este processo de planejamento e gerenciamento local se justifica pelo fato de se poder verificar o que acontece de bom e ruim nas administrações públicas, quanto ao processo de planejamento e gestão urbana. Desta forma, aprende-se com os acertos, reflete-se sobre o que está errado, propiciando uma troca muito rica de experiências.

Os municípios escolhidos para este trabalho são Cuiabá e Várzea Grande, em Mato Grosso, sendo que as cidades formam um aglomerado urbano, e os estudos ficariam mais completos estudando as duas cidades.

O aglomerado urbano Cuiabá - Várzea Grande ocupam lugar de destaque para Mato Grosso e parte da Região Norte (Rondônia, Acre e parte da Amazônia), pois Cuiabá é a capital do Estado e o Aglomerado e polo referência na prestação de serviços diversos, na dinâmica do comércio, e vem fomentando cada vez mais seu parque industrial, sendo o destaque para o agro-negócio. Por isso a importância de se cuidar das questões urbanas. Num mundo globalizado, a localidade deverá se preparar adequadamente para os novos desafios que se apresentam, sendo o planejamento urbano (e todos os instrumentos por este utilizado) fundamental para se obter sucesso nas ações, a partir da racionalização na forma de se utilizar os recursos. O plano diretor bem elaborado e uma máquina administrativa eficiente são pontos de partida para obter bons resultados. 
Cuiabá e Várzea Grande realizaram a revisão de seus planos diretores, como aplicaram os instrumentos apresentados pelo Estatuto da Cidade terá grande importância para que se realize o controle urbano, pois representam o amparo legal na execução das ações (tendo em vista o princípio constitucional da legalidade ${ }^{3}$ no setor público). Os planos diretores destes municípios deverão estabelecer formas democráticas de participação popular nos processos de planejamento e gestão urbana, e ainda garantir a continuidade deste processo. Esses deverão ainda estar sintonizados um com o outro (o plano de Cuiabá com o de Várzea Grande) para que seja possível enfrentarem problemas que dizem respeito a ambas, superando suas diferenças e suas desigualdades, construindo canais para o diálogo e ações afinadas entre ambas.

\section{OBJETIVOS}

Este trabalho tem como objetivo geral a análise dos planos diretores dos municípios do Aglomerado Urbano Cuiabá - Várzea Grande, a fim de verificar como foram utilizados os instrumentos urbanísticos oferecidos pelo Estatuto da Cidade nos planos diretores atuais, e quais as principais ações que as prefeituras estão realizando para transformar em realidade o conteúdo destes planos. A análise deverá ser realizada frente à realidade dos municípios e frente ao fato das cidades serem conurbadas, verificando-se como os planos têm tratado os problemas comuns.

São objetivos específicos:

1- Analisar se os planos diretores atuais foram construídos segundo os princípios e objetivos do Estatuto das Cidades e como foram construídos.

2- Analisar como os instrumentos urbanísticos (tanto os antigos, como os oferecidos pelo Estatuto da Cidade) foram incorporados nos planos diretores, a partir do conhecimento das características e dos problemas dos municípios estudados, destacando:

a) a auto-aplicabilidade dos planos;

b) as propostas para a gestão do território urbano, da habitação, do meio ambiente, do saneamento ambiental, da mobilidade urbana;

c) as propostas para a participação da população na gestão da cidade.

\footnotetext{
${ }^{3} \mathrm{O}$ princípio da legalidade estabelece que o poder público não possa agir se não estiver amparado por lei, e deverá ainda, agir estritamente de acordo com esta.
} 
3- Verificar como as prefeituras estão administrativamente estruturadas para colocar em prática os planos diretores, e quais as ações (ou políticas) que estão previstas, em andamento, ou que já foram realizadas para que os planos diretores se tornem a realidade concreta.

4- Identificar ações realizadas a nível de aglomerado urbano e de prefeituras na busca de soluções para os assuntos comuns entre os municípios.

\section{METODOLOGIA DE PESQUISA}

Como método de pesquisa será adotado a pesquisa qualitativa.

Segundo PORTELA (2004), (...) "pesquisa cientifica exige, entre outras características, a criatividade, a disciplina, a organização e a modéstia do pesquisador, devem-se levar em conta que ele lida sempre com confrontos".

A pesquisa qualitativa tem segundo GODOY (1995) apud NEVES (1996), como principais características:

- A não preocupação com estatísticas numéricas.

- O enfoque indutivo.

- A descrição dos fenômenos e ambientes estudados.

- O ambiente natural é a sua fonte de informações.

- O significado que as pessoas dão às coisas e à sua vida como preocupação do investigador.

Diz NEVES (1996):

"a pesquisa qualitativa costuma ser direcionada, não busca enumerar ou medir eventos e, geralmente, não emprega instrumental estatístico para análise dos dados; seu foco de interesse é amplo e parte de uma perspectiva diferenciada da adotada pelos métodos quantitativos. Dela faz parte a obtenção de dados descritivos mediante contato direto e interativo do pesquisador com a situação objeto de estudo."

O pesquisador procura o porquê das coisas, utiliza procedimentos de interpretação utilizados em seu cotidiano, o vínculo entre signo e significado depende da interpretação do pesquisador, que se vale de diferentes abordagens.

GODOY (1995) apud NEVES (1996) defende três possibilidades de abordagem para a pesquisa qualitativa: 
- A pesquisa documental: que analisa documentos com fins de lhe dar uma interpretação nova.

- O estudo de caso: visa o estudo de um ambiente, de uma situação particular.

- A etnografia: onde o pesquisador passa a conviver por um tempo com a comunidade estudada e através de técnicas de observação para diagnosticar e explicar alguns fenômenos e seu sentido.

Pode-se, contudo, utilizar várias abordagens na realização de um trabalho, de forma que elas se complementem.

Pautada na pesquisa qualitativa, este trabalho trata nitidamente de um estudo de caso, no entanto, a abordagem dependeu da fase e do assunto estudado.

Os estudos para a realização desta dissertação se dividiram em quatro etapas.

$\mathrm{Na}$ primeira etapa, foi realizada uma extensa pesquisa bibliográfica sobre assuntos referentes ao:

- Planejamento urbano e planos diretores.

- O Estatuto da Cidade - seus objetivos, diretrizes e instrumentos urbanísticos.

Nesta fase, a pesquisa foi elaborada através de leitura de teses, dissertações, artigos, livros, revistas e outras publicações referentes aos temas.

Na segunda fase, a pesquisa foi voltada às cidades do aglomerado urbano Cuiabá - Várzea Grande, e pesquisou-se:

- A formação das cidades em um contexto histórico.

- Suas características: sociais, físicas, políticas, culturais.

- A formação do aglomerado urbano.

Foi consultado todo o material impresso disponível, livros, revistas, artigos de jornais locais, internet, materiais existentes nas prefeituras (mapas e impressos), e entrevistas com técnicos das prefeituras.

A terceira fase foi constituída do estudo dos planos diretores dos municípios de Cuiabá e Várzea Grande, onde foi estudado, tendo como base o Roteiro do Ministério das Cidades:

- A utilização dos instrumentos urbanísticos disponíveis na legislação do país.

- A aplicação dos princípios e instrumentos contidos no Estatuto da Cidade, consistindo na análise das seguintes questões:

a) como eram os planos diretores anteriores aos atuais;

b) quais os estudos que subsidiaram a elaboração dos planos diretores atuais; 
c) qual a metodologia utilizada para a construção dos atuais planos diretores;

d) qual o conteúdo dos planos diretores (apresentam uma estratégia para as áreas territorial e ambiental e para o desenvolvimento do município?);

e) a linguagem do plano (permite que a população leiga o compreenda?);

f) como foram tratados os instrumentos que possibilitam o acesso à terra urbanizada, a regularização fundiária e quais os instrumentos para uma política fundiária;

g) como será a função social da propriedade nos municípios;

h) como se dará o controle do uso e ocupação do solo;

i) tratou-se de questões referentes ao perímetro urbano e estabeleceram diretrizes para o parcelamento do solo;

j) quais os coeficientes urbanísticos que foram estabelecidos para cada zona;

k) como ficou o zoneamento, tornará mais acessível a terra urbanizada para as camadas desfavorecidas?

1) como foi tratada nos planos diretores a política para habitação popular;

m) como ficarão as questões referentes a mobilidade, transporte e ao sistema viário;

n) foi analisado como os planos trataram o saneamento básico, a infra-estrutura, e as questões ambientais;

o) qual a posição dos planos diretores quanto ao Aglomerado Urbano;

p) qual a estrutura administrativa das prefeituras;

q) como se dará a gestão e o acompanhamento dos planos e das ações que visam à implementação dos planos diretores? Como será a participação democrática da população?

- Foram analisadas as políticas e ações que acontecem nas prefeituras e no aglomerado urbano para se obter conhecimento sobre o que acontece para a implementação dos Planos Diretores.

Foi verificado se os planos estão afinados um com o outro ou se possuem questões conflitantes, e se estão adequados à realidade de cada município.

Esta fase foi respaldo nos planos diretores, na legislação complementar, em estudos e análise de planos e programas, e em entrevistas com técnicos das prefeituras. A análise dos dados foi apoiada nos estudos sobre os municípios realizados anteriormente. 
Constou da quarta etapa a elaboração da conclusão da dissertação e apresentação da bibliografia utilizada.

Para as etapas finais, a pesquisa qualitativa foi utilizada por permitir a interpretação dos dados a partir de valores de difícil medição, que só podem ser mensurados a partir da ponderação do observador. Para tanto, tornou-se importante todo o estudo anterior e o conhecimento profundo do objeto estudado (as cidades, o Estatuto da Cidade e os planos diretores de cada uma, assim como a estrutura administrativa voltada para o planejamento urbano), para embasar a análise dos dados e a conclusão. 


\section{CAPÍTULO 1 - REVISÃO BIBLIOGRÁFICA}

\section{1- OS PLANOS E O PLANEJAMENTO URBANO NO BRASIL}

Planejamento Urbano possui vários conceitos conforme o tempo e objetivo. Para RATTER (1978) é: "Organizar racionalmente a ocupação do espaço, como condição para a melhoria das relações sociais e do próprio estilo de vida das populações."

Segundo NAMUR (1992; pág. 4). "Ao falar em planejamento, está-se referindo às intervenções do aparelho estatal no espaço urbano (políticas estatais urbanas), que tendem a regular as contradições surgidas tanto no processo de reprodução de força de trabalho, como de reprodução dos meios de produção; ou seja, o planejamento urbano caracteriza-se antes de tudo como um instrumento de intervenção que depende fundamentalmente da relação entre o Estado e as classes sociais".

VILLAÇA (1999), diz que “... aquilo que nas últimas décadas tem sido denominado planejamento urbano (e que nas décadas de 30 e 40 se chamava urbanismo) é a ação do Estado sobre a organização do espaço intraurbano".

Segundo VILLAÇA (1999), podemos dividir a história do planejamento urbano (ou do urbanismo) no Brasil em três períodos, o primeiro começando em 1875 até 1930, o segundo de 1930 até 1990 e o terceiro de 1990 até a atualidade.

O primeiro período, segundo o mesmo autor "foi marcado pelos planos de melhoramento e embelezamento". "Estes planos tinham como característica a monumentalidade, a exaltação a uma burguesia, a destruição da forma urbana medieval, e se inspirava no urbanismo de Versalhes, de Washington, de Haussmann e de Pereira Passos. Avenidas e praças surgiam destruindo casarios coloniais. Esta europeização das cidades, promovida pela classe dominante que também dirigia a cidade, era aplaudida por todas as classes sociais".

"A França foi o principal referencial, com o seu planejamento de origem renascentista, que enfatizava a beleza monumental, ao mesmo tempo em que vinha impregnado de ideologia, visto que glorificava e ajudava a impor o Estado e a classe dominante capitalista à população. Tratava-se não apenas de discurso, mas de ações concretas do Estado, que nem sempre tinham os mesmos objetivos pregados nesses discursos”. Diz VILLAÇA (1999; pág. 193):

"Foi sob a égide dos planos de embelezamento que nasceu o planejamento urbano (lato sensu) brasileiro". 
"Este nascimento se daria em 1875, com a utilização de 'conceitos chaves' ou seja, das palavras "planos" e gerais" (ou conjunto, ou global) associadas ao espaço urbano no primeiro relatório apresentado pela comissão de Melhoramentos da cidade do Rio de Janeiro.

Entre a década de 1930 e 1940, grandes planos guiaram a reformulação do centro do Rio de Janeiro e de São Paulo. "O Plano Agache - para o Rio de Janeiro - data de 1930 e foi o primeiro que apresentou a expressão Plano Diretor, em São Paulo, Prestes Maia abria avenidas para resolver os problemas de circulação". "Os interesses imobiliários já estavam por traz dos Planos de embelezamento e dos programas de incremento do sistema viário, estes grandes projetos urbanos eram discutidos, acompanhados e financiados pelo setor". As cidades (Rio de Janeiro e São Paulo, porque pelo tamanho já acumulavam problemas e necessitavam de preparo para a industrialização crescente) mantinham nas primeiras décadas, uma política de planejamento urbano, e seus planos eram transformados em ações, apoiadas, debatidas e incorporadas pela classe dominante. VILLAÇA (1999).

Os planos de embelezamento foram depois substituídos pelos de infra-estrutura, pois a classe economicamente dominante passou a exigi-la para que as indústrias tivessem condições de se implantar. As obras de embelezamento e melhoramento, antes consumidas por todos, eram anunciadas com antecedência e festejadas; as de infraestrutura, que passaram a dominar a segunda metade do século $\mathrm{XX}$, eram geralmente escondidas, pois beneficiava uma parcela reduzida, e privilegiada, da população. Os Planos e de modo geral o Planejamento Urbano, passa a ser desconsiderado, embora ainda reconhecido como necessário, pelo setor público. A eficiência das cidades é mais valorizada que a questão da beleza, e segundo VILLAÇA (1999; pág. 199): "Passa-se da "cidade bela" para a "cidade eficiente", da cidade do consumo para a cidade da produção". Em ambas, entretanto, o interesse imobiliário estará sempre fortemente presente.

Entre a década de 1930 e 1950, a burguesia, cujo poder econômico vinha da indústria, ainda que não conseguisse responder aos problemas urbanos que já incomodavam as classes trabalhadoras, conseguiam, fosse qual fosse o governo (a ditadura de Getúlio Vargas ou a democracia), executar as obras de seu interesse, nas partes da cidade que lhes aprouvesse, podendo ser a remodelação do centro ou as de infra-estrutura. Entre 1930 e 1965, passou-se “... do planejamento que era executado para o planejamento-discurso". VILLAÇA (1999). 
Nos anos 1960 com a crescente urbanização brasileira, o governo, após o golpe militar, precisava dar uma resposta aos problemas urbanos mais imediatos, uma vez que debates acalorados eram travados nas esferas técnica, política, econômica e em diferentes classes. Sensível à questão, especialmente no que tangia a falta de habitação, o governo criou, em 1964, o SERFHAU, como agente técnico do sistema financeiro da habitação, com o objetivo de organizar o espaço habitacional. No SERFHAU, o problema habitacional ocupava posição principal, e o da infra-estrutura ficava em segundo plano. Em 1966, o SERFHAU foi regulamentado como o órgão responsável pela elaboração e coordenação da política nacional no tocante a um planejamento urbano integrado, em consenso com a política estabelecida para a região. TOLOSA (1977), in TOLEDO (1978). O planejamento local foi objeto de grande atenção enquanto o regional foi pouco cuidado.

Conforme TOLOSA (1977), in TOLEDO (1978; pág. 40): “O planejamento Local Integrado (PLI) era entendido como a elaboração de planos e projetos que, eram compatibilizados entre si e onde era compreendido os aspectos econômicos, sociais, físicos e institucionais, visavam ao desenvolvimento a nível municipal. Propunha-se, portanto, um tratamento interdisciplinar para os problemas municipais, apesar de na prática, ter-se verificado ênfase excessiva nos problemas físico-urbanísticos."

O financiamento dos Planos de Desenvolvimento Locais Integrados (PLI) era propiciado por um fundo denominado Fundo de Financiamento para o Planejamento Local (FIPLAN), criado com recursos do Banco Nacional de Habitação (BNH). TOLOSA (1977), in TOLEDO (1978).

O Planejamento Local era realizado em duas etapas. A primeira era constituída por um estudo preliminar, que geralmente concluía pela necessidade da segunda fase, o Plano de Desenvolvimento Local Integrado. Para a implementação das obras apontadas nos planos, o Ministério do Interior lançou um Programa de Ação Concentrada (PAC), onde a filosofia baseava-se na idéia de que o planejamento deveria iniciar-se na menor unidade - o município - para alcançar os níveis mais altos. Sendo o município visto como um ente autárquico, desprezando-se suas ligações e relações com outras cidades e regiões. Esta falha provocou distorções e equívocos na aplicação dos recursos, agravando muitas vezes as desigualdades regionais, como no caso do Sudeste e do Sul. TOLOSA (1977), in TOLEDO (1978)

Apesar da intenção original do SERFHAU, de promover uma integração entre os interesses locais e as políticas regionais, isto nunca foi colocado em prática. As ações do 
PAC visavam uma ocupação do território nacional, porém os objetivos do PLI eram vagos e imprecisos, subentendendo-se que seriam deixados por conta dos municípios.

Segundo TOLOSA (1977), in TOLEDO (1978; pág. 42):

“(...) A falta de objetivos mais precisos, a inconsistência entre as proposições dos planos e os instrumentos controlados pelas autoridades locais e a descontinuidade administrativa estão entre as principais causas das dificuldades encontradas para implantação dos Planos. Além do mais, a maioria dos Planos Locais ficava limitada a diagnósticos das economias municipais".

Para o autor acima citado, fica clara a falta de entrosamento entre os Planos Locais e a política urbana, num projeto macroeconômico proposto pelo governo federal e, portanto, concluiu que não houve uma política voltada ao Planejamento Urbano no período entre os anos de 1964 até 1975. Pois a produção de Planos Locais não é condição suficiente para que exista uma política de planejamento, principalmente porque faltava definir como esses planos se tornariam realidade, como se concretizariam. A grande maioria não saiu do papel, não passando de diagnósticos.

Naquela época entendia-se que o problema residia na formulação de uma política urbana que compreendesse o espaço como social, fruto da distribuição de renda, de forma que as intervenções fossem respaldadas pela economia, e pela compreensão de como se estruturava o espaço brasileiro, para dotá-lo de condições suficientes para melhor distribuir as redes de cidades. Assim, o Plano Nacional de Desenvolvimento I PND (1971-1974), continha algumas diretrizes que norteavam a política da época como o desenvolvimento econômico e transformação social, que deveriam ser realizados através de um processo de integração, e de articulação entre regiões desenvolvidas e as em desenvolvimento. Falava-se de uma integração articulada considerando-se os recursos ociosos de cada região como a mão de obra não qualificada do Nordeste, as terras e recursos minerais no Norte e Centro-Oeste que deveriam ter um melhor aproveitamento local, a fim de conter os fluxos migratórios para o Centro-Sul.

O II PND marcou uma reformulação no processo de planejamento urbano, que passa a dar destaque para a política urbana a nível nacional, priorizando-se as regiões metropolitanas, embora o discurso pregue a desconcentração destas localidades, com exceção de São Paulo, onde se desconcentrou a industrialização para a região de Campinas e do Vale do Paraíba, nas demais o efeito foi o inverso. TOLOSA (1977) in TOLEDO (1978; pág. 43). 
A cidade foi vista como uma unidade de produção onde ao tanto se produzia como se consumia, e inevitavelmente se relacionava o urbano com o desenvolvimento industrial.

A criação de polos regionais resolveria esta questão. Porém, contradizendo tais objetivos, uma das diretrizes contida na síntese do II PND, já dizia que se esperava consolidar até o final da década de 1970, "uma sociedade industrial moderna e um modelo de economia competitiva. Essa economia moderna com seu núcleo básico no Centro-Sul..." houve então uma dissociação entre organizar o espaço e economia. A política urbana baseou-se em uma visão setorialista, de forma que as prioridades eram estabelecidas com base no setor de transporte, ou saneamento urbano, ou habitacional, ou drenagem etc., com prioridade para as Regiões Metropolitanas. Essa política acabou por acentuar mais as desigualdades regionais. A política urbana então moldada com base em programas estratégicos foi de certa forma um retrocesso. SOUZA, in DEÀK (1999; pág. 117 e 118).

Alguns avanços sem dúvida foram notados, como a continuidade de uma política, o mapeamento e reconhecimento do território brasileiro nas mais diversas áreas e a preocupação com os problemas urbanos, que explodiam com o Brasil aumentando espantosamente sua população e passando a ter maioria dela vivendo nas cidades,

Houve contudo pequena atenção para com as cidades médias localizadas em outras regiões como o caso de Campo Grande, Corumbá, Dourados, Cuiabá, Macapá, Boa Vista, Rio Branco etc., embora nunca tivesse bem claro como dinamizá-las na época. TOLOSA (1977) in TOLEDO (1978; pág. 43).

Segundo NAMUR (1992), “a partir de 1970, os planejadores urbanos brasileiros repensaram seu papel, buscando a compreensão dos limites profissionais, rediscutindo a ideologia (do positivismo de Comte ao estruturalismo de Weber) e alguns conceitos pregados até então. As discussões giravam em torno dos conceitos e da análise das relações entre a política urbana, o Estado e o desenvolvimento sócio-econômico de um período determinado".

Assim, nos anos 1960 apareceram vários conceitos para planejamento. Uma das correntes largamente difundidas pela literatura americana é a do planejamento como critério da "racionalidade". NAMUR (1992) diz o seguinte:

(...) "O critério de "racionalidade" no planejamento estatal implicava nas noções de melhor uso dos recursos públicos e na adequação entre os meios e fins no processo de tomada de decisões 
políticas, e conduziria a idéia de planejamento como uma técnica neutra, funcionando como um guia para o desenvolvimento da sociedade como um todo, onde a organização social era tida como dependente de fatores espaciais, técnicos e biológicos ao invés de sê-lo de relações de classe e conflitos". NAMUR (1992; pág. 9).

Conforme NAMUR (1992), "na mesma época, outra corrente liberal da ciência política americana, partindo da base da existência de um pluralismo político, defendeu a idéia de que o planejamento urbano põe em jogo muitos interesses, e por isso se firmam alianças e se desencadeiam vários conflitos".

"A tarefa dos planejadores urbanos seria a de um mediador, na qualidade de quem possui conhecimento do que é possível ou não de ser realizado, competiria a ele delimitar e orientar o debate, direcionando para a realização de um compromisso objetivando certos fins comuns a todos. A racionalidade então não está na coerência entre meios e fins, mais no denominador comum mínimo entre os interesses do sistema (conjunto), e a atuação concreta de poder que resulta da atividade de cada ator." SCHNORE (1968), apud NAMUR (1992).

"Ambas as correntes, as chamadas de tecnocrática (que conceitua planejamento como uma técnica neutra) e a liberal (que conceitua planejamento como "mediador de conflitos" e a política estatal como produto de "decisões e estratégias" de atores autônomos) refletem o pensamento da escola de sociologia tradicional (fundamentalista) e da ciência política liberal. CASTELLS (1972 e 1976) criticou tais teorias, enfatizando que elas eram importantes para o planejamento urbano, para a integração social e para a satisfação dos interesses dos grupos dominantes da sociedade. Nelas, a organização social dependeria de fatores espaciais, técnicos e biológicos, no lugar das relações e dos conflitos de classe. Concordando com ele, LOJKINE (1979) e POULANTZAS (1968), criticam também tais teorias por apregoar o Estado como elemento externo às estruturas sociais, como se estas relações sociais se reduzissem a somatória das vontades individuais e por tomar o Estado como "agente da vontade geral, acima das particulares". As políticas públicas seriam consequentemente construídas a partir de decisões estratégicas de agentes autônomos. Assim, o Estado capitalista reflete as lutas de classe, e as políticas do Estado são relacionadas com os interesses da classe capitalista dominante”. NAMUR (1992), pág. 3.

"Planejamento urbano não seria apenas uma atividade técnica, mas uma atividade técnica-política, ao contrário do que apregoa a corrente tecnicista (predominante na década de 1960) onde os meios são para atingir os fins, reconhece-se 
que o aparelho estatal é o reflexo das lutas de classe travadas na sociedade civil, e portanto, torna-se instrumento para concretizar os interesses hegemônicos de classe, num certo período". NAMUR (1992, p. 4).

O terceiro período viria após a Carta constitucional de 1988. Segundo MARICATO (1994) citada por VILLAÇA (1999; pág. 232), “os anos 70 foram marcados por um fortalecimento da consciência popular quanto aos problemas urbanos, porém sempre eram abafadas pelo governo ditatorial dos militares". "No final dos anos 1980, com a elaboração da nova Constituição (1988), seis entidades nacionais e várias regionais enviaram ao Congresso Nacional, uma proposta de Emenda Popular à Constituição com várias questões urbanas sendo que se destacavam as referentes á questão fundiária, habitacional, transportes e gestão urbana”. Estas massas segundo VILLAÇA (1999) in DEÀK (1999; pág.262), "não reivindicavam Planos Diretores, pois já estavam cansadas de discursos ideológicos, mas queriam ações concretas, e trazia à tona aquilo que nunca era resolvido, a imensa população que vivia clandestina em situação precária, porque toda a legislação e a ação do governo se destinavam a uma cidade legal, aquela a quem se destinava o zoneamento, as leis de loteamento, e a infraestrutura que o estado produzia". Desta forma a cidade clandestina passou a exigir providências, frente ao caos urbano eminente.

A resposta ao clamor popular veio em forma dos artigos 182 e 183 da Constituição de 1988 (já comentados na problemática e na justificativa deste trabalho), porém, o Plano Diretor continuou a ser o instrumento que definiria (ao menos teoricamente) os rumos da cidade, especialmente a função social da propriedade urbana, nos termos que melhor se encaixasse no município. A constituição reconheceu a importância do planejamento e gestão urbanos, mesmo que faltasse a regulamentação de como o controle da propriedade deveria ser realizada, ficando os municípios à espera da lei, que transitava a anos no legislativo. A Constituição obrigou os municípios que não tivessem planos diretores, a providenciá-los, ou revisá-los se fosse o caso, o que foi feito (mais uma vez) aos moldes antigos, na maioria das cidades (com exceção das cidades onde a existência de uma organização popular, exigiu que se estabelecesse um debate e uma negociação). Quem os elaborou foram os técnicos em gabinete, e muitas vezes a serviço dos mesmos poderosos de sempre, ou mesmo como exercício intelectual desligado da realidade da cidade. Estes planos, multissetoriais, foram como os antigos e tradicionais - meros enumerados de problemas ou dados sobre a cidade - na grande 
maioria dos casos não foram seguidos (nem respeitados) e só serviam para contentar um artigo legal, não respondendo a contento aos problemas urbanos.

VILLAÇA (1999) in DEÁK (1999; pág. 235 e 236), argumenta que: “A década de 1990 foi selecionada como fim de um período da história do planejamento urbano brasileiro porque marca o início do seu processo de politização, fruto do avanço da consciência e organização populares". E segue dizendo que tal amadurecimento trouxe a recusa do diagnóstico técnico como o revelador de problemas da população, uma vez que: “A população está cansada de saber quais são os seus problemas”. (grifo meu). Logo os problemas urbanos não seriam questões referentes à técnica, e sim, uma questão política.

Os planos elaborados a partir da década de 1990 passaram a utilizar a nomenclatura de "planos estratégicos" o que lhes conferia um aspecto de modernidade, frente ao "processo de globalização", que vem atribuindo ao município um novo papel. Este discurso tem sido utilizado para vários propósitos, inclusive o especulativo.

Conforme MARICATO (2002) "na Segunda Conferência das Nações Unidas para os Assentamentos Humanos da ONU, realizada em Istambul em 1996, houve um consenso na importância das cidades para a qualidade de vida das pessoas, devendo ser então concedido a estas uma maior autonomia”. Mas não é qualquer cidade que poderia ter o status de uma cidade-estado, só as "cidades globais".

Estas cidades, segundo a autora acima citada, "seriam os centros onde se decidiriam o destino das pessoas ao redor do mundo por abrigar as sedes das grandes empresas financeiras e grandes corporações empresariais, serem centro de pesquisas e criação (especialmente no que diz respeito às tecnologias de ponta, informática e comunicações), por concentrarem a mão de obra qualificada, as universidades, e serviços sofisticados, além de intensas atividades culturais e artísticas de vanguarda. Para se tornarem "globais" as cidades precisam seguir a formula oferecida por consultores renomados, e o modelo mais vendido para a América Latina são os Planos Estratégicos, vestidos de democracia ao apregoar os princípios participativos, a proposta para os municípios latino-americanos se ajusta perfeitamente aos interesses do capitalismo neoliberal que balizou o Consenso de Washington".

O Consenso de Washington foi um encontro que aconteceu nesta cidade em 1998, do qual fizeram parte, além de representantes do governo americano, o FMI Fundo Monetário Internacional - o Banco Mundial e o BID - Banco Internacional de Desenvolvimento, entre outros representantes de paises "emergentes". Formularam-se 
as regras que deveriam ser seguidas para que os paises e as cidades, especialmente as de economia periférica, se ajustassem às novas exigências capitalistas do mundo globalizado, e apesar de maquiado de democracia, levaram muitos paises a se subordinarem às regras ditadas pelos organismos internacionais (principalmente para conseguir recursos financeiros). MARICATO (2002).

Para todas as localidades do mundo, a receita era a mesma:

“(...)1) disciplina fiscal; 2) priorização (ou "racionalização") dos gastos públicos; 3) reforma tributária; 4) liberalização financeira; 5) regime cambial; 6) liberalização comercial; 7) investimento direto estrangeiro; 8) privatização; 9) desregulamentação; e 10) propriedade intelectual”. MARICATO (2002; pág. 58).

As recomendações foram abraçadas pelo Brasil, e na escala local, passa a ser moderno e atual o fato dos municípios adotarem os Planos Estratégicos que cumpre o papel desregulamentar, privatizar, fragmentar e propiciar ao mercado o espaço absoluto para transformar a cidade em produto a ser vendido e consumido, com o objetivo de extrair renda e lucro, deve ser tratado como se fosse uma empresa privada bem administrada.

A cidade deve ser preparada para atuar neste novo cenário global e então as antigas formas de planejamento são substituídas pelas estratégias de atuação no território. Espaços antigos são renovados, hotéis estrelados e aeroportos internacionais, centros culturais e centros de convenções são construídos para que vários espaços se valorizem, trazendo lucro a especuladores imobiliários. A cidade deixa de ser apenas o local onde as pessoas interagem, trabalham e vivenciam seu cotidiano, para se transformar em símbolo, em mercadoria onde o uso da imagem e da cultura local são fatores chave para os Planos Estratégicos. MARICATO (2002)

Houve uma confusão ideológica, em torno dos planos estratégicos, proporcionada pela valorização da participação popular, porque acaba por subordinar os interesses de muitos aos interesses hegemônicos de poucos, legitimando de forma ideológica as suas ações. Estes Planos ocuparam o espaço deixado pelos planos modernistas e burocráticos, que amarravam as cidades, não consideravam as potencialidades e as peculiaridades de cada comunidade, e assim, não respondiam bem às novas condições. Frente à crise fiscal dos anos 1990 e o recuo do Estado central em relação às políticas sociais e urbanas, foi a saída encontrada por prefeitos que se depararam com o aumento da demanda por serviços públicos e a falta de recursos. Os 
Planos Estratégicos alimentaram as disputas por investimentos travadas pelas cidades, e contribuiu para desviar a atenção da população dos problemas nacionais para o foco no local, nem tudo se resolve no plano local. MARICATO (2002)

Então, conforme Maricato (2002), o Consenso de Washington e o Plano Estratégico se complementaram, um agindo a nível nacional, e o outro em nível local. Após as duas ultimas décadas as cidades têm um novo papel frente a um mundo cada vez mais urbano e frente ao estreitamento dos mercados proporcionado pelas novas tecnologias de comunicação, e produção e o novo ritmo de fluxos de capital financeiro determinam novas práticas e novos desafios, mas as velhas formas de dominação, corrupção e clientelismo continuam presentes na nossa sociedade. MARICATO (2002).

O Plano Estratégico mostrou-se deslocado por não contemplar, nem no discurso, a cidade como um todo, tendo em vista que apenas as partes consideradas mais importantes e visíveis é objeto de intervenção.

\section{2- O ESTATUTO DA CIDADE E A POLÍTICA URBANA}

O Estatuto da Cidade obrigou que os municípios se adequassem às novas premissas por ele impostas, fazendo com que praticamente todos a ele submetidos revisassem (ou fizessem) seus Planos Diretores aos seus moldes. A nova lei contém inovações em termos de princípios e instrumentos que poderão ser utilizados pelos municípios para promover as reformas e transformações urbanas tão sonhadas.

Assim o envolvimento de toda a sociedade para reverter este cenário tem sido, no decorrer das últimas décadas, uma das principais questões política e social debatidas, pois já se torna impossível a convivência com a desigualdade que impera no cenário urbano (físico e social).

Segundo BRASIL (2004), “o sistema urbano brasileiro, em suas diferentes fases, sempre teve como característica a concentração e a irregularidade da estrutura fundiária. Os investimentos públicos sempre foram para beneficiar os especuladores, pois as obras realizadas com o importo pago por todos, se reverte a favor dos mais ricos. Socializamse então os gastos e se privatizam os lucros e os benefícios. Esta concentração de riquezas e propriedades nas mãos dos ricos estrutura as cidades e refletem as relações econômicas, sociais e políticas revelando os mecanismos de poder na estruturação do espaço". 


\subsection{1- A LUTA PELA REFORMA URBANA}

A primeira lei que tratou das questões referentes às questões urbanas de forma geral no país foi o Decreto Lei $\mathrm{n}^{\circ}$. 58/1937, e visava coibir a proliferação de loteamentos irregulares, cujos donos deixavam sem o título de propriedade seus compradores. Tempos depois, a mesma questão foi regulamentada na Lei $n^{\circ}$. 6766/1979 (ainda em vigor, porém sendo revista pelo Legislativo Federal) que ao traçar requisitos mínimos que deveriam estar presentes nos loteamentos, e instituir penalidades aos loteadores que agirem de má fé ou em discordância com a Lei. Esta instituiu as primeiras regras urbanísticas, que apesar de se limitar aos loteamentos, já trazia a exigência de se destinar uma porcentagem das terras para áreas verdes e para equipamentos públicos, entre outras regras que auxiliariam no planejamento urbano se tivessem sido respeitadas. Porém a realidade das cidades, principalmente de suas periferias, mostrou que a lei não foi aplicada quando se tratava de loteamentos para as classes populares, e assim inúmeros loteamentos se tornavam clandestinos, sem a possibilidade de regularização e consequentemente, inúmeras famílias não puderam ter seus títulos de propriedade.

A semente do Estatuto da Cidade foi o Projeto de Lei $n^{\circ}$. 775/1983, formulado pelo CDHU (Conselho Nacional de Desenvolvimento Urbano) que era o órgão responsável pelo planejamento urbano na esfera federal e em plena ditadura militar. Ele propunha o desenvolvimento urbano com um forte alcance social, recepcionando os objetivos das lutas pela reforma urbana que bem antes, já eram amplamente debatidos em eventos como o Primeiro Seminário de Habitação e Reforma Urbana que reuniu políticos técnicos e outros estudiosos em Petrópolis - RJ em 1963. Neste encontro a questão da moradia deu ênfase às discussões sobre o modelo de desenvolvimento e a necessidade de se intervir de maneira mais substancial para enfrentar a problemática. Contudo as manifestações populares foram duramente silenciadas durante o período em que a ditadura militar esteve no poder. CHILETTO (2005)

O silêncio só começou a ser quebrado na década de 1980, quando o processo de redemocratização do país propiciou o aparecimento de várias lutas populares, como as greves organizadas pelos sindicatos, a batalha pelas eleições diretas (diretas já) para Presidente do Brasil, os debates para a elaboração da nova Constituição Federal. Os temas referentes às más condições de moradia nas cidades era uma constante nas discussões. Os movimentos populares, amadurecidos e politizados, exigiam que 
providências fossem tomadas para a melhoria da qualidade de vida nas cidades, especialmente para os menos favorecidos. A reforma urbana desejada, segundo SOUZA (2002) "seriam políticas articuladas que fariam a redistribuição e universalização dos benefícios, voltados para reduzir o nível de injustiça social no meio urbano, a partir da democratização do planejamento e da gestão das cidades".

Os movimentos populares se engajavam em lutas para denunciar as péssimas condições urbanas que a classe desfavorecida estava vivendo, e cobravam uma atitude de seus representantes para restabelecer o seu direito a condições dignas de vida e à inclusão social, indispensáveis para o exercício pleno da cidadania. "Aos movimentos comunitários se juntaram representantes dos movimentos sindicais, profissionais de diversas áreas, técnicos, estudiosos e se constituiu o Movimento Nacional pela Reforma Urbana (MNRU) e apresentou uma Emenda Constitucional de iniciativa popular à Assembléia Legislativa Nacional Constituinte, tratando da Reforma Urbana. Assim os diversos atores unidos neste movimento, conseguiram ultrapassar seus maiores desafios que era a fragmentação das lutas cotidianas de cada um”. GRASIA de GRÀSIA (2003).

Contudo num ambiente democrático, opiniões não são unânimes e os debates travados embora focassem as questões relativas à regularização e uso do solo urbano expressos na Emenda popular, surgiram dois grupos com idéias distintas: de um lado os planejadores públicos com aquele antigo ponto de vista restrito da realidade, e de outro lado, os movimentos populares, reivindicando práticas inovadoras e democráticas, com a ampla participação social tanto no planejamento como na gestão da cidade. Já não se pensava somente nas questões da habitação e do uso do solo urbano, mas se desejava qualidade em outros aspectos decisivos para a qualidade de vida urbana como o transporte de qualidade, o acesso aos serviços e equipamentos públicos, e a infraestrutura presente nas localidades mais improváveis. A reforma constitucional era o momento para que os movimentos populares buscassem com êxito a desejada justiça social urbana.

Lefebvre (1991), diz que "somente o proletariado pode utilizar sua própria força para transformar sua realidade. Só ele pode investir sua atividade social e política para realizar a sociedade urbana desejada ao renovar o sentido das atividades produtivas e criadoras, a cidade passa então a ter um valor de uso e não um valor de troca e de lucro. Renovar a cidade não seria apenas mudar os aspectos urbanos, mas os valores que animamos homens e para tanto se deve utilizar os mais variados meios disponíveis na ciência, na arte, na técnica, e assim produzir um novo humanismo para o homem 
urbano, onde o que importa é a solidariedade, a troca harmônica entre os homens e entre estes e a natureza e não mais o lucro vindo da ganância e do egoísmo camuflado por uma ideologia que serve à uma camada privilegiada".

As lutas populares buscaram a concretização de suas aspirações na modificação ou na elaboração de uma legislação urbanística. Para ROLNIK (1997; pág. 13) citada por CHILETTO (2005; pág. 87):

"Mais do que definir formas de apropriação do espaço permitidas ou proibidas, mais do que efetivamente regular a produção da cidade, a legislação urbana age como marco delimitador de fronteiras de poder. A lei organizada classifica e coleciona os territórios urbanos, conferindo significados e gerando noções de civilidade e cidadania diretamente correspondentes ao modo de vida (...) Funciona, portanto, como referente cultural fortíssimo na cidade, mesmo quando não é capaz de determinar sua forma final. Aí reside, talvez, um dos aspectos mais interessantes da lei: aparentemente funciona, como uma espécie de molde da cidade ideal ou desejável. Enquanto (...) ela determina apenas a menor parte do espaço construído, uma vez que o produto- cidade - não é fruto da aplicação inerte do próprio modelo contido na lei, mas da relação que esta estabelece com formas concretas de produção imobiliária na cidade. Porém, ao estabelecer formas permitidas e proibidas, acaba por definir territórios dentro e fora da lei, ou seja, configura regiões de plena cidadania e regiões de cidadania limitada."

O poder público municipal foi eleito pela Constituição de 1988 o principal responsável por estabelecer qual é a função social da sua cidade, que dependeria das características de cada uma, segundo o desejo de seu povo, realizando desta forma o ideal de justiça social conforme suas peculiaridades. Logo novas formas de planejamento urbano deveriam ser estabelecidas de forma a contemplar as aspirações dos mais variados grupos sociais, e não apenas de uma minoria, todos deveriam ser ouvidos. A nova forma de se planejar deveria levar em consideração as conquistas no âmbito internacional como a Agenda 21 e a Agenda Habitat, com especial destaque para o meio ambiente. Desta forma o Planejamento inovador abrangeria um campo social, político e físico, implementando através de leis que contemplem mecanismos de inclusão social, para que a comunidade tenha como intervir no processo de reflexão, construção e gestão urbana. Práticas de planejamento aos moldes do Físico Territorial, tão pregado pelos modernistas e largamente utilizado no período da ditadura, de características rígidas, onde tudo era regulado e com um alto grau de segregação de atividades - e pessoas, ou mesmo o seu sucessor na década de 1980, o Planejamento Estratégico, que busca através da análise de efeitos da urbanização, traçar os passos futuros de maneira ordenada para se alcançar um objetivo, mesmo já utilizando alguns 
princípios como o desenvolvimento sustentável, a participação social, a forma menos rígida que viriam a ser definitivamente incorporados pelo Estatuto das Cidades, se mostraram, tanto um como o outro, ineficientes e desajustados da real necessidade popular, pois continuavam servindo apenas a uma classe mais poderosa. Assim, segundo SOUZA (2002), o planejamento e a gestão urbana buscaram a reforma e sua transformação não partindo de idéias importadas, mas de soluções originariamente brasileiras.

Conforme CHILETTO (2005), "a Constituição Federal de 1988 ampliou o rol das competências concorrentes entre Municípios, Estados e União, o que vem causando omissões e atropelos e os recursos destinados aos municípios são insuficientes para toda a demanda, mas a descentralização proporcionou um maior grau de liberdade que permitiu novas formas de articulações. Estes fatores impulsionaram as administrações mais progressistas e comprometidas com a universalização das ações, buscaram proporcionar para todos, a oportunidade de participar dos debates e da gestão urbana. Foram introduzidas a partir de então ações locais que obtiveram sucesso e foram exemplos que se disseminaram. Então as primeiras práticas de Planejamento Participativo se constituíram de diálogos e negociações entre os técnicos do governo e as associações de moradores, em algumas cidades. Muito embora muitas das visões pontuais das comunidades a cerca do urbano não ultrapassasse um foco local, esta experiência induziu o surgimento de outras práticas como o Orçamento Participativo, combatendo, de certa forma, o clientelismo, a concentração de recursos e a desconexão entre os diversos gastos públicos, ao mesmo tempo em que legitimaram as ações do poder público local".

Foram onze anos de tramitação legislativa, inúmeros embates onde os conflitos entre os vários interesses foram explicitados e discutidos, o Projeto de Lei inicialmente apresentado foi inúmeras vezes modificado e por fim os artigos 182 e 183 da Constituição foram regulamentados pela aprovação da Lei $n^{\circ}$. 10.257 de 10 de julho de 2001 de iniciativa do Senador Pompeu de Souza, passando a vigorar três meses depois.

O Estatuto da Cidade, somado às outras legislações urbanísticas de âmbito federal como a Medida Provisória 2.220/2001 e a Lei dos Consórcios, estabelecem as diretrizes da política urbana no Brasil, abrangendo os três níveis de governo.

A partir da entrada em vigor do Estatuto da Cidade, o interesse público passou a predominar sobre os demais, então o direito individual que regia as relações urbanas, especialmente no que tange o direito de propriedade, foi substituído pelo direito 
coletivo, bem mais apropriado para tornar as cidades sustentáveis, e serem reconhecidas como produto de uma coletividade. O Estatuto ofereceu várias diretrizes e instrumentos que dão aplicabilidade aos artigos constitucionais por ele regulamentados, proporcionaram condições de se concretizar a função social da cidade.

Os Planos Diretores Participativos tomaram lugar de destaque nesta nova etapa do planejamento brasileiro, tendo em vista que o Estatuto da Cidade, os artigos constitucionais que tratam da política urbana só poderão ter eficácia plena se ajustados às necessidades e desejos de cada cidade individualizada, pois cada uma deverá utilizar os instrumentos oferecidos pelo Estatuto da Cidade conforme suas peculiaridades, o que é um ponto positivo já que não são todas iguais neste vasto território.

Aos planejadores urbanos também vêm cabendo um novo e grande desafio, pois o planejamento urbano agora não se restringe às ações corretas tecnicamente, bem embasadas em dados científicos, mas deverão estar associados às questões políticas, tributárias, orçamentárias, jurídicas e principalmente à vontade da população, devendo se estabelecer o diálogo democrático constante e o acordo.

\subsection{2- OS PRINCÍPIOS E DIRETRIZES PARA O PLANEJAMENTO URBANO NO BRASIL}

Ao ser promulgado, o Estatuto da Cidade vinculou aos seus princípios, diretrizes e instrumentos, toda a legislação urbanística a ser formulada pelos Estados e Municípios, assim nada poderá vir de encontro a seus preceitos.

O Estatuto da Cidade, Lei № 10.257 de 10 de julho de 2001, veio regulamentar os artigos 182 e 183 da Constituição Federal, e estabelece as diretrizes gerais para a política de desenvolvimento urbano, tendo em vista o interesse social, o bem estar e a segurança do cidadão, regulando o uso da propriedade urbana e sempre tendo em vista o ambiente natural.

A política urbana tem como objetivo ordenar o pleno desenvolvimento das funções sociais da cidade e da propriedade urbana. Segundo FERNANDES (2002), citado por CHILETTO (2005), este princípio já constava nas constituições brasileiras desde 1934, porém com outras interpretações (segundo os interesses de cada época) somente na atual Constituição de 1998 é que vem sido interpretado de forma mais consistente, e para tanto deve estar determinada na legislação urbanística, especialmente a municipal. 
Para CHILETTO (2005; pág. 92 e 93):

"O conceito de reforma urbana deve ser entendido como o conjunto das políticas destinadas a garantir a universalização do acesso aos bens e serviços urbanos e o direito democrático à participação nos processos de planejamento e gestão. Neste contexto a função social da propriedade compreende a supremacia do coletivo sobre o domínio particular. A propriedade privada foi questionada face à garantia do acesso de todos os moradores à cidade, expressa nos artigos que permitem a usucapião urbana e buscam restringir a especulação imobiliária."

Com isto passa-se a reconhecer que existe uma cidade vivendo na ilegalidade, a cidade "real" e que esta população teria o direito de viver em terras ocupadas, pois estas terras estariam sendo reservadas para lucros maiores no futuro, e encarecimento do solo e da habitação devido às complexas relações de mercado. Legitimou-se então a ocupação de imóveis por esta população desprovida conferindo-lhes o direito à legalização na forma da lei.

Estão entre as principais diretrizes trazidas pelo Estatuto da Cidade conforme o art. $2^{\text {o. }}$

- A gestão democrática por meio da participação da população e de associações representativas dos vários segmentos da comunidade na formulação, execução e acompanhamento de planos, programas e projetos de desenvolvimento urbano.

- Cooperação entre os governos, a iniciativa privada e os demais setores da sociedade social.

- Atividade permanente de planejamento tendo em vista o desenvolvimento e melhoria da qualidade de vida nas cidades.

- A Produção de bens e também consumo de modo sustentável, buscando a preservação ambiental quando necessário.

- Promoção da integração e da complementação entre atividades, benefícios e serviços urbanos e rurais.

- Ordenação e controle do uso do solo, evitando usos inadequados, deterioração de localidades e poluição e destruição ambiental, entre outros.

- A justa distribuição dos benefícios e ônus decorrentes do processo de urbanização.

- Adequação dos instrumentos de política econômica, tributária e financeira e dos gastos públicos aos objetivos do desenvolvimento urbano. 
- Realização de audiências entre o Poder Público municipal e a população interessada nos processos de implantação de empreendimentos ou atividades impactantes.

- Regularização fundiária e urbanização de áreas ocupadas por população de baixa renda.

- Simplificação da legislação urbanística.

São, porém, os instrumentos da política urbana que possibilitarão o controle territorial nas cidades, dependendo de forma decisiva do Poder Público Municipal, sendo os municípios os grandes protagonistas na implantação das políticas públicas urbanas.

\subsection{3- INSTRUMENTOS PARA A TRANSFORMAÇÃO URBANA}

Para que os princípios possam se concretizar, o Estatuto oferece vários instrumentos que serão citados e descritos sinteticamente.

Consoante XAVIER (2005; pág. 28), para melhor exemplificação, classificou-os em três grupos que serão adotados neste trabalho para melhor compreensão da natureza dos objetivos principais de cada um.

I-) Instrumentos de Indução ao Desenvolvimento Urbano, sendo eles:

- "parcelamento, edificação e utilização compulsórios (Arts. $5^{\circ}$ e $6^{\circ}$ );

- IPTU progressivo no Tempo (Art. $7^{\circ}$ );

- desapropriação com pagamento em títulos da dívida pública (Art. $8^{\circ}$ );

- consórcio Imobiliário (Art. 46);

- $\quad$ outorga onerosa do direito de construir (Arts. 28 a 31);

- direito de superfície (Arts. 21²4);

- transferência do direito de construir (Art. 35);

- operações urbanas consorciadas (Arts. 32 a 34);

- direito de preempção (Arts. 25 a 27).

II-) Instrumentos de regularização Fundiária:

- “usucapião especial de imóveis urbano (arts. 9ª 14);

- direito de superfície (Arts. 21 a 24);

- concessão de uso especial para fins de moradia (Art. $6^{\circ}$ );

- concessão do direito real de uso (Arts. $2^{\circ}$ e 48)". 
III-) Instrumentos de democratização da gestão urbana:

- “órgãos colegiados de política urbana (Arts. 43 a 45);

- audiências e consultas públicas (Arts. 43 a 45);

- conferências sobre assuntos de interesse urbano (Arts. 43 a 45);

- Estudo de Impacto de Vizinhança, EIV, (Arts. 36 a 38)".

Muitos destes instrumentos só poderão ser utilizados se estiverem com área de abrangência definidas no Plano Diretor Municipal, além de regulamentação em lei específica. Nestes casos, não seria de interesse público que todas as localidades do município estivessem sujeitas a tais instrumentos, como é o caso das áreas para o parcelamento, edificação ou utilização compulsória, as sujeitas ao IPTU progressivo no tempo, as destinadas à desapropriação com títulos da dívida pública e outorga onerosa do direito de construir.

Também não se submetem ao Plano Diretor Municipal, e à regulamentação legal, o Direito de Preempção, as Operações Urbanas Consociadas, a Transferência do Direito de Construir e as Zonas Especiais de Interesse Social. Fica evidente que o Estatuto da Cidade elegeu o Plano Diretor como sendo o instrumento básico norteador da política de desenvolvimento urbano, que subsidiará inclusive as ações especificadas no Plano Plurianual, a Lei de Diretrizes orçamentárias e Lei Orçamentária Anual.

Muitos dos instrumentos regulamentados pelo Estatuto da Cidade, como explica OLIVEIRA (2001), "são semelhantes a alguns adotados internacionalmente para controle do uso do solo urbano, e a maioria deles já se conhecia no Brasil, mas a adoção era muito restrita por vários empecilhos como impedimentos de ordem cultural, histórico, jurídico e principalmente os decorrentes de interesses políticos". Mas a situação que as cidades vêm vivenciando, impõe o uso de todos os esforços, e instrumentos, existentes para enfrentamento do problema. Desta forma, a Lei regulamenta os instrumentos para a realização da política urbana, classificados quanto a sua natureza em tributários, jurídicos, financeiros, econômicos, administrativos e políticos.

O Estatuto da Cidade, assim como a Constituição já havia feito, conferiu ao Plano Diretor Municipal grande importância, pois é a partir desta Lei que se poderá aplicar muitos dos Instrumentos aqui citados, desta forma a letra da lei deverá ser traduzida e espacializada conforme as características de cada município. 
O plano diretor é uma lei municipal, aprovada pela Câmara de vereadores, e é o instrumento básico da política de desenvolvimento e expansão urbana.

Fazendo parte integrante do processo de planejamento municipal, devendo o plano plurianual, as diretrizes orçamentárias e a Lei de orçamento anual, assim como as demais leis, devem estar de acordo com o seu conteúdo.

A propriedade urbana só cumprirá sua função social quando atende às exigências fundamentais de ordenação da cidade expressas no Plano Diretor. Este deverá englobar o território do Município como um todo, logo a parte urbana e a rural, e deverá ser revisto pelo menos a cada dez anos.

Na elaboração do plano diretor e na fiscalização de sua implementação, os Poderes Legislativo e Executivo municipais garantirão a promoção de audiências públicas e debates, a publicidade quanto aos documentos e informações produzidos e o livre acesso aos documentos e informações produzidos.

Segundo o Art. 41, o plano diretor é obrigatório para cidades:

I - com mais de vinte mil habitantes;

II - integrantes de regiões metropolitanas e aglomerações urbanas;

III - onde o Poder Público municipal pretenda utilizar os instrumentos previstos no art. 182 da Constituição Federal; parágrafo $4^{\text {o; }}$

IV - integrantes de áreas de especial interesse turístico;

$\mathrm{V}$ - inseridas na área de influência de empreendimentos ou atividades com significativo impacto ambiental de âmbito regional ou nacional.

Nas cidades com mais de quinhentos mil habitantes, deverá ser elaborado um plano de transporte urbano.

O conteúdo mínimo do plano diretor, segundo o Art. 42 é o seguinte:

I - a delimitação das áreas urbanas onde poderá ser aplicado o parcelamento, edificação ou utilização compulsória, considerando a existência de infra-estrutura e de demanda para utilização, na forma do art. $5^{\circ}$ do Estatuto da Cidade;

II - as disposições requeridas pelos arts. 25, 28, 29, 32 e 35 desta Lei;

III - o sistema de acompanhamento e controle.

O processo participativo foi a grande inovação e um diferencial de suma importância para o cidadão. A democratização da participação popular, assim como o amadurecimento dos grupos sociais para poderem plenamente tomar parte deste processo, ainda encontra barreiras de ordem política, social, técnica e cultural. Mas surpreendentemente, as audiências públicas e as Conferências das Cidades que têm sido 
realizadas pelo Brasil, têm atraído cada vez mais munícipes interessados em participar dos assuntos ligados à sua cidade.

Outra questão tratada no Estatuto da Cidade foi a gestão democrática da cidade que deverá ser garantida com a utilização, entre outros, dos seguintes instrumentos:

I - órgãos colegiados, nos níveis nacional, estadual e municipal;

II - debates, audiências e consultas públicas;

III - conferências sobre assuntos de interesse urbano, nos níveis nacional, estadual e municipal;

IV - iniciativa popular de projeto de lei e de planos, programas e projetos de desenvolvimento urbano;

Não será fácil, contudo, que prefeitos (especialmente os mais conservadores e autoritários) antes acostumados a decidirem sozinhos, conforme seus interesses, compreendam e propiciem condições para se realizar o direito da população opinar, e mais do que isto, de ver sua opinião transformada em ação.

Em muitas localidades, no entanto, a Lei tem sido até cumprida, mas as audiências populares acabam se tornando objeto de legitimação da vontade de poucos. Utiliza-se o velho discurso ideológico, de forma que não se leva a sério a vontade popular, adiando-se as decisões e as ações de seu interesse, com as velhas desculpas da eterna falta de verba ou de outras prioridades.

\section{3- AS DIFICULDADES DO PLANEJAMENTO URBANO NO} BRASIL

O processo de urbanização no Brasil tomou rumos dramáticos. Para MARICATO (2002), “o urbanista - baseado em um bom diagnóstico - não pode se esquivar de apresentar propostas que venham ao encontro do interesse público, e deverá apresentá-las para o debate público. Ainda que seja um esboço".

Os que tomam a posição de esquerda se recusam a apresentar propostas porque acreditam que planejamento é competência do Estado e este é a expressão das classes dominantes, logo não se pode fazer planejamento democrático para que todos se beneficiem dele. Por outro lado, aceitar como verdade absoluta que o urbanismo reproduz o status quo é como decretar a morte do urbanismo propositivo. As dificuldades que os urbanistas têm em formular propostas, principalmente nas prefeituras democráticas pós ditadura, mostra o despreparo dos profissionais para lidar 
com a questão. MARICATO (2002) coloca uma série de questões que deverão ser respondidas pelos urbanistas.

“(...) Que fazer com a cidade ilegal e violenta? E com as áreas ambientalmente frágeis, ocupadas pela moradia pobre? Quais seriam as soluções, a curto e médio prazo, para as tragédias decorrentes de enchentes, desmoronamentos, incêndios, e epidemias? Como enfrentar o mercado imobiliário altamente especulativo e excludente? Como combinar a ocupação do solo urbano e o sistema viário com as unidades de gestão baseadas em bacias e sub-bacias hidrográficas? Como implementar a função social da propriedade? Como fazer, objetivamente, o controle do uso do solo (um dos setores mais corruptos das gestões municipais) protegendo áreas ambientais frágeis e assegurando a ampliação de ofertas de moradias sociais? Como convencer a sociedade e governos das prioridades demandadas pelos problemas de drenagem e saneamento? Que fazer com o comércio informal que ocupa os espaços públicos? Como garantir alguns padrões mínimos de habitação em favelas já urbanizadas? Quais são estes padrões mínimos para o conforto domiciliar, a circulação viária e de pedestres, as áreas públicas, a coleta de lixo, o saneamento e sua manutenção? Como fomentar o engajamento social para a resolução de problemas que ultrapassem as reivindicações pontuais?" pág. 49.

As respostas segundo a autora, não são nem um pouco simples de serem dadas. Estes problemas não existem no Primeiro Mundo e mesmo no Brasil não foram muito estudados e nem enfrentados (salvo poucas exceções). Durante o período de ditadura a gestão participativa era reprimida fortemente, mas passado este período, algumas gestões inovadoras passaram a se destacar, o que permite pensar que existem condições de se realizar um planejamento urbano democrático, mas ainda são grandes os constrangimentos. MARICATO (2002)

Quando se pensa em planejamento democrático, em propostas alternativas democráticas e participativas para as nossas cidades, se depara com inúmeros problemas que impõem limites a esta prática. MARICATO (2002) cita como exemplo que:

- "não há possibilidades de se intervir no ambiente construído independente da sociedade que o constrói e habita, pois ele é um reflexo das relações sociais nele existente, é objeto e agente de permanência e das mudanças sociais. Especialmente numa sociedade como a brasileira, muito desigual, autoritária, baseada em relações de privilégio e arbitrariedades, as cidades terão estas características, o que não impede de reconhecer que a cidade é um campo de lutas entre as classes sociais;

- a dificuldade de lidar com a máquina pública administrativa. Não só pela burocracia imposta, mas pelo distanciamento entre prática e discurso; 
- a origem exógena da inspiração".

E entre tantos resultados desastrados a autora destaca:

a) "a aplicação arbitrária da legislação, uma vez que o poder econômico e político determinam como, e quando a lei será aplicada;

b) a cidadania não é conferida a todos igualmente, e as relações são tecidas baseadas em privilégios de forma que quem possui poder econômico, tem direitos. Quem não possui, sobram os deveres;

c) as esferas públicas e privadas se confundem e o clientelismo e relações de favor ocupam o lugar da lei;

d) a esfera pública tem "donos" o que fica claro com a quantidade escandalosa de cargos públicos distribuídos aos apaniguados, parentes ou utilizados e a máquina pública utilizada em proveito próprio;

e) a cultura local utilizada como enfeite;

f) o distanciamento da realidade local, dado pela óptica das universidades, e a produção intelectual estrangeira;

g) os primórdios do ensino superior no Brasil foram baseados na formação de profissionais liberais, especialmente os advogados, engenheiros e médicos, mas embora se apresentasse como profissionalizante, era livresco, dogmático e desfocado da prática;

h) a concepção histórica de que as pessoas letradas (os bacharéis e estudiosos) não fazem o trabalho manual, braçal, visto que este não tem o mesmo valor do trabalho intelectual. Logo não entram em contato com o problema para conhecê-lo de perto e propor soluções realizáveis. Este modo de pensar leva para os gabinetes um número exagerado de funcionários públicos para pensar sobre os problemas e apresentar soluções, mas na hora de realmente colocar em prática as idéias, são poucos os funcionários, e geralmente estão mal preparados, sem condições de trabalho, é mal remunerado e extremamente exposto à corrupção (a corrupção reina em muitos setores);

i) o Estado tradicionalmente costuma absorver mão de obra ociosa da classe média. Políticos são verdadeiros donos de partes da administração (os melhores cargos principalmente) e utilizam os cargos públicos para distribuir empregos muitas vezes para garantir votos. MARICATO (2000)

Estas práticas, herdadas do colonialismo, continuam vivas e atuantes em pleno século XXI, a despeito de toda a legislação existente e de todos os problemas que até hoje esperam uma resposta. 
MARICATO (2002) questiona como é possível planejamento urbano democrático diante de um quadro deste? Porque para planejar, é preciso de uma continuidade administrativa e a construção de um pacto social em torno de uma proposta. Mas o que vemos?

"Funcionários, não tão públicos; "poder público" privatizado; planos que são numerosos mas que dormem nas gavetas, ou seja, planos sem planejamento; secretarias ou departamentos municipais de planejamento urbano (e não são poucos os funcionários públicos dedicados a essa função em todo o Brasil) fazendo de conta que fazem planejamento, sem compromisso com a gestão e a fiscalização do uso do solo; enfim, planejadores que não planejam...”

"Com tudo isso, há o muito que fazer, pois a realidade grita por uma resposta que deve, necessariamente, prever ações e investimentos no tempo. E isso exige planejamento." (Pág. 56).

Construir um caminho entre o pensamento crítico e a prática não é simples, e exigirá esforços, porém, uma vez iniciado o processo, será irreversível e as mudanças serão grandes.

"Se o urbanismo no Brasil revelou-se "idéias fora do lugar" e as cidades brasileiras cresceram aceleradamente sem planejamento, temos por um lado os planos funcionalistas utilizados durante grande parte do século XX que tratavam a cidade a partir de uma visão geral, holística, mas não funcionaram", (MARICATO (2000) "pois o discurso era universal e sua implantação quase sempre não passava de papéis engavetados". VILLAÇA (1999). Já o Plano Estratégico aborda a cidade de forma fragmentada, em partes, conforme o potencial de rentabilidade imobiliária ou importância simbólica de cada lugar.

Existiria então um caminho para o planejamento urbano no Brasil? Conforme MARICATO (2000) "o caminho para o planejamento e gestão que contrarie os rumos atuais exige alguns pressupostos abaixo descritos".

\section{a) Adquirir a consciência da cidade real e indicadores de qualidade de vida.}

Para conhecer a face oculta, ilegal e degradada da cidade, um eficiente instrumento é conhecê-la cientificamente. A desigualdade se apresenta no tratamento dado pela mídia, pelo mercado imobiliário, pelos padrões de serviços públicos oferecidos, e até pelos mapas e cadastros oficiais da administração pública (certas localidades nem constam em mapas). É na parte legal da cidade que se concentram os maiores investimentos públicos. 
As universidades e ONGs podem contribuir na tarefa de trazer à tona a realidade urbana das nossas cidades, pois inúmeros exemplos demonstram o desconhecimento destas questões por parte do judiciário, do legislativo e da mídia. Não se administra bem uma cidade sem o conhecimento de seu território (inclusive sua ocupação).

Instituir indicadores permite desmontar o marketing político que engana a população em épocas de eleições, e permite verificar desempenhos, identificar quais são e qual o tamanho dos problemas, as urgências e ainda permite a comparação com outros municípios.

b) Propiciar espaços democráticos de debate, dando assim, visualidade aos problemas.

A sociedade brasileira tem a tradição de não reconhecer a existência de conflitos sociais, é como se eles não existissem por aqui embora vasta bibliografia comprove a violência das relações sociais. O embate democrático é substituído pela repressão e pela desmoralização do interlocutor quando se fala de luta de classes. Não havendo a tradição do debate democrático, prevalece a versão dominante "do pensamento único". Pior ainda é a utilização da ideologia neoliberal que toma como consenso democrático construído pela coletividade, o pensamento autoritário de poucos.

A construção de espaços democráticos para estabelecer debates igualitários é um grande desafio, mas possui um grande poder transformador. A construção destes espaços de convivência e a administração de conflitos, ao lado da formação de cidadãos interlocutores dos problemas da cidade talvez seja uma das principais tarefas dos governantes municipais para a superação das desigualdades no contexto urbano. Na prática tem se observado que os mais humildes apresentam propostas pontuais, relacionados aos seus problemas e a seu espaço cotidiano, enquanto a elite, sempre bem assessorada, apresenta - pretensiosamente - propostas para toda a cidade. Estes espaços propiciaram o esclarecimento das reais intenções e dos verdadeiros interesses em jogo. Os Conflitos, uma vez revelados, deverão ser enfrentados, pois apenas elogios à participação social (que é uma unanimidade entre diversos organismos internacionais como ONU, Habitat, Banco Mundial etc.) e a instituição de conselhos e audiências públicas não bastam, as propostas devem ser operacionalizadas.

\section{c) Reforma administrativa.}


As administrações municipais são, na grande maioria dos casos, arcaicas, acostumadas a procedimentos baseados em privilégios, trocas de favores, em lobbies de empreiteiros e empresários que se apropriam através dos políticos, da máquina pública. A máquina pública foi se adequando minimamente às demandas que o crescimento da cidade exigia, mas não se modernizou.

Para que o poder público conheça e enfrente a cidade real, é preciso uma ampla reforma que vai desde seu arcabouço jurídico até a redefinição das atribuições operacionais, levando os gabinetes para perto da realidade.

Vê-se com unanimidade a fragmentação da administração em secretarias, departamentos, empresas e autarquias, cada um oferecido a um partido político diferente que deu apoio à eleição do prefeito, e assim, os problemas (que são interdisciplinares e exigem um tratamento comum), ficam sem solução pela dificuldade de serem atacados em sua totalidade. Políticas de inclusão social dependem desta abordagem integrada, porque é um todo (economia, cultura, educação, saúde, ações no campo jurídico, saneamento, equipamentos públicos e meio ambiente, etc.) não pode ser visto parcialmente e combatido apenas por um - ou poucos - setores da administração pública.

Assim um novo agente público deverá ser formado e preparado, junto com a formulação de novas propostas para a administração pública (deverá inclusive estar preparado para o trabalho em equipe e junto à sociedade, ouvindo e ponderando soluções).

\section{d) Formação de quadros e agentes para uma ação integrada.}

A formação de nova política urbana requer agentes qualificados nos mais diversos campos da ciência (campo jurídico, da engenharia, arquitetura, urbanismo, geografia, meio ambiente entre outros.) porque as intervenções físicas devem ser acompanhadas de outras ações no campo da saúde da educação da oferta de empregos e melhoria da renda familiar, combate à violência e assistência psicológica.

\section{e) Aperfeiçoamento e democratização da informação.}

Quanto ao sistema de informação municipal, podemos dizer que salvo poucos casos, encontra-se um caos. Os cadastros são desatualizados, arcaicos, e fragmentados. A cidade ilegal (as áreas griladas, as favelas, os alagados, as invasões em área de preservação) não é cadastrada. Os cadastros não são compatíveis entre si, nas regiões 
metropolitanas, cada município - ou mesmo cada secretaria - possui seu cadastro (e um geralmente é incompatível com o outro, não se completando). Ter acesso a eles é difícil, até mesmo para os seus próprios funcionários, e pior ainda é o acesso concedido (quando é concedido) ao cidadão comum.

"Sem incorporar o conhecimento científico ao diagnóstico e acompanhamento das cidades é impossível implementar uma gestão democrática”. MARICATTO (2002; pág. 78)

A falta de conhecimento da cidade acaba beneficiando interesses patrimonialistas de alguns.

\section{f) Formulação de um programa especial para regiões metropolitanas.}

No Brasil, há mais de 50 milhoes de pessoas em cidades pertencentes a uma região metropolitana, duas destas regiões são maiores que muitos países, e $80 \%$ das favelas estão em nove regiões metropolitanas, mas mesmo assim, o país não possui nenhuma política institucional para estas regiões. A resolução de problemas comuns fica a critério dos municípios, o que acaba sendo muito difícil (quase impossível).

Devido ao volume dos problemas que ultrapassam as fronteiras de cada município integrante de regiões metropolitanas, estas merecem maior atenção por parte dos governos das escalas superiores (Estadual e Federal). Deste modo os seus espaços de ocupação consolidada necessitam de requalificação ou urbanização, da mesma forma que a instância federal deveria promover programas habitacionais e urbanos para minimizar a grande concentração de pobreza e de violência que se multiplicam especialmente nas áreas segregadas, pobres e degradadas destas localidades.

\section{g) Adoção das bacias hidrográficas como referência para o planejamento e} gestão.

As políticas regionais estão fortemente atreladas às relações econômicas sobre a ocupação territorial e as informações demográficas estão consolidadas neste campo. Mas outras variáveis devem ser agregadas para que as relações advindas das relações de produção sejam complementadas com as variáveis determinadas pelas necessidades sociais. Desta forma:

"As bacias e micro bacias hidrográficas são unidades obrigatórias para a abordagem do planejamento urbano, na medida em que o destino 
do esgoto e do lixo sólido, para citar apenas dois resíduos das aglomerações urbanas, interfere, praticamente, na vida de todos os usuários da mesma bacia”. MARICATTO (2002; pág.79 e 80).

Este princípio já tem sido adotado em planos regionais, como no caso do Estado de São Paulo. Em matéria de legislação, estamos adiantados, mas na prática, a adoção de bacias como unidade de planejamento, ainda está muito distante. Tanto o urbanismo modernista tradicional ignorou os aspectos naturais regionais, e assim também o faz o planejamento de matriz neoliberal. Contudo, nas ultimas décadas, com a intensificação dos movimentos ambientalistas disseminados por todo o mundo, o planejamento territorial regional concebido a partir das bacias hidrográficas começou a se impor e sua adoção é apenas questão de tempo.

\section{h) Formulação de políticas de curtíssimo, médio e longo prazo.}

Há um atraso na implementação de medidas, especialmente nas regiões metropolitanas e nos aglomerados urbanos. Tragédias continuam a ocorrer, demandando grandes recursos financeiros e trabalho tanto para sua prevenção como para seu socorro. Os governos locais estão - quase sempre - despreparados para os dois casos. Porém as atuações são diferentes, para tanto exigem diferentes medidas.

As gestões devem estar preparadas para agir em situações que requeiram respostas imediatas, assim como também para formular ações a médio e longo prazo. A construção de pactos sociais leva certo tempo (falta a tradição de participação). A formação de funcionários para que realmente se envolvam de maneira concreta com o seu objeto de estudo, saindo de seus gabinetes e conhecendo o problema concretamente, assim como formar funcionários para agir nestes diferentes estágios (políticas de curtíssimo, médio e longo prazo) e a troca de experiências mudaria os rumos do planejamento ao aproximá-lo do mundo concreto e real.

Como foi observado, não é por falta de planos e nem por falta de leis (e nem mesmo por falta de recursos financeiros) que as cidades colecionam inúmeros problemas, pois mesmo antes do Estatuto da Cidade, possuíam instrumentos suficientes para que os planos fossem aplicados e então cumprissem o que prometiam: um desenvolvimento, equilibrado e sustentável, proporcionando qualidade de vida aos seus habitantes. No entanto, vemos que a lei se mostra severa, cheia de detalhes para as partes mais valorizadas, e extremamente benevolentes nas periferias, locais onde a especulação imobiliária não tem interesse. Vemos que só na cidade legal, há 
fiscalização das normas urbanísticas por parte do poder público municipal. Nas favelas, loteamentos clandestinos, alagados e beiras de córregos, fecham-se os olhos para as irregularidades, pois o Estado não tem como responder (ou não pretende responder) aos problemas dessa população.

Ciente dos problemas que dificultam o planejamento urbano no Brasil, o que se pode esperar do Estatuto das Cidades? Teria esta Lei a capacidade de mudar o rumo preocupante do crescimento urbano nas cidades?

Os inúmeros problemas urbanos não foram causados pela falta de planejamento e nem pela ausência de planos porque sempre existiram. Porém a realidade política e social nas quais as cidades brasileiras se inserem exigem mudanças na forma de se realizar planejamento urbano, visto que as formas tradicionais não se mostraram eficientes, mas sim deslocadas da realidade vivida no país.

O Estado utilizado pelas elites capitalistas, historicamente utilizou o dinheiro público para proporcionar a estrutura adequada, para que uma parcela da população tivesse acesso a uma cidade bonita, bem cuidada e equipada com tudo o que se precisa para viver bem. Através das obras realizadas pelo poder público (seja local, regional ou nacional) muitos empresários lucraram com a valorização do solo e com a infraestrutura que os beneficiavam gratuitamente. Contudo, a situação tornou-se insustentável e a parcela excluída da população passou a cobrar a parte dos benefícios que lhes cabe. A luta pela reforma urbana teve como fruto o Estatuto da Cidade, lei que tem sido a esperança de mudanças concretas nos rumos que as cidades brasileiras tomaram. Não é, contudo, tarefa fácil.

O Estatuto da Cidade é uma lei que contém instrumentos que podem ser muito úteis para auxiliar na transformação da triste realidade urbana que assola as cidades brasileiras, em especial as médias e as grandes. Porém é fundamental que sejam observados os seus princípios, utilizando adequadamente os seus instrumentos e principalmente que se tornem ações concretas, não apenas discurso bem formulado. Desta forma esta Lei é um instrumento para o desenvolvimento e definição da ocupação dos municípios, além de prever a participação popular na gestão não só territorial, mas geral.

Para que seus objetivos sejam realmente alcançados, deverá ser modificada a maneira de se fazer planejamento urbano no Brasil, pois não se tem a tradição de ouvir a população e construir pactos a partir da apreciação das diversas alternativas, do embate entre os diversos interesses, o que representará uma imensa evolução. A população 
deverá ser preparada para seu novo papel no processo de planejamento e gestão das cidades, assim como os técnicos das diversas áreas envolvidas no processo urbano, os políticos e os diferentes grupos e representações populares. A obrigatoriedade da participação popular em todo o processo (desde o diagnóstico dos problemas, às formas de solução, até a fiscalização da implantação das ações, passando pela fiscalização dos recursos) é um grande avanço, embora seja uma construção lenta e nem um pouco fácil e tranqüila, mas poderá trazer inúmeros benefícios pára a população em geral.

O Plano Diretor, foi eleito tanto pela Constituição de 1998, como pelo Estatuto da Cidade como protagonista das reformas, pois a ele toda a Legislação municipal deve se submeter. É a partir dele que se formatará a cidade, segundo a vontade democrática da população. "A questão da participação popular, contudo acabou tendo um papel secundário em vista dos demais instrumentos de controle e desenvolvimento urbano, principalmente porque o Estatuto deu pouca ênfase aos conselhos de desenvolvimento urbano" SOUZA (2002).

O plano diretor participativo segundo o Estatuto da Cidade, não deverá ser como os das décadas anteriores, documentos cujas propostas eram impossíveis de se realizar, feitos por uma elite de técnicos em gabinetes, ou encomendados para cumprir uma formalidade legal ou ainda, para promover uma ideologia da classe dominante. Estes planos ou eram um amontoado de informações ou documentos vazios, sem aplicabilidade, que acabavam engavetados e desconhecidos da população. O plano diretor deverá ser uma lei amplamente conhecida, construída pela comunidade, e posteriormente por ela fiscalizada. Na sua elaboração e revisão deve ser levada em consideração a realidade do município e as ações contempladas com o poder de concretização.

Para tanto não se poderá prescindir de se gerar e de se manter um banco de dados atualizados para o município, pois o conhecimento amplo da cidade é uma determinante para que se possa proporcionar para todos uma visão geral e um conhecimento mais profundo do município. Também deve se investir num sistema tributário justo e atualizado, sem o qual não se terá a justiça social. Por fim, o preparo da população para que, a partir do conhecimento da realidade de sua cidade, possa participar de forma mais atuante é um ponto a ser amplamente trabalhado. Para isso é necessário que a prefeitura coloque todas as informações geradas à disposição de todos, pois o espaço urbano é constantemente alterado, sendo produto da atuação de diversos atores com diferentes desejos e pontos de vista. As informações devem ser socializadas, 
utilizando-se inclusive dos sistemas mais modernos e eficazes para a divulgação, como a internet.

A questão da distribuição de receitas é outro problema sério a ser enfrentado. As prefeituras, a despeito de ser o poder mais próximo do povo e de ter tantas obrigações, fica com a menor parte dos tributos, $5 \%$ da receita total arrecadada pelo Estado brasileiro. Outra questão a ser considerada é o desenvolvimento regional, pois o Estatuto cumpre perfeitamente seu papel enquanto instrumento para o desenvolvimento local, mas, em época de globalização não se pode desconsiderar questões regionais e nada foi previsto para as relações intermunicipais, de forma que ficou uma lacuna ao se desconsiderar por completo as questões regionais e metropolitanas. Sabe-se que $40 \%$ da população CÂMARA DOS DEPUTADOS (2004) vive em regiões metropolitanas ou aglomerados urbanos, e não se pode fechar os olhos para os problemas que decorem destas aglomerações, deixando tudo para ser resolvido a partir do diálogo e da boa vontade dos políticos, pois apesar da negociação ser um bom meio, é morosa e não tem se mostrado de todo eficiente.

O Estatuto da Cidade proporcionou um novo entendimento do Planejamento Urbano, de forma que é um instrumento passível de conseguir, a partir de uma árdua tarefa, a realização dos objetivos propostos. Constitui um desafio aos planejadores urbanos porque a Lei ainda permite impedimentos de ordem jurídica, cultural, histórica e política, além da dificuldade de articulação entre os diversos atores (tanto dos sociais como dos entes da federação).

Apesar de existirem entraves, são muitos os progressos alcançados como: a possibilidade de um controle espacial adequado à dinâmica das atividades, as novas possibilidades de ocupação e zoneamento, a preocupação com o meio ambiente, a possibilidade de diálogos entre os diversos grupos, o controle mais rigoroso das ações do poder público municipal pela população, a participação do povo no processo de planejamento e na gestão do município, entre outros. Podendo contar com o poder do Ministério Público, agindo como fiscal da Lei, e não permita que o Estatuto da Cidade seja transformado em letra morta em municípios, cujas administrações são arcaicas, conservadoras e autoritárias, frustrando o desejo da população pela mudança, ressaltando-se que poucas leis em nosso país foram construídas com tanto esforço da população em geral e com tanta legitimidade. 


\section{CAPÍTULO 2 - $\quad$ AS CIDADES DE CUIABÁ E VÁRZEA GRAMDE}

\section{1- BREVE HISTÓRIA DE CUIABÁ E VÁRZEA GRANDE}

Cuiabá está localizada no Centro Geodésico da América do Sul, esta localização tão interiorana foi decisiva na sua criação, há quase trezentos anos atrás, influenciando na formação da cidade, nos usos e costumes do povo local, contribuindo para a formação da rica cultura cuiabana.

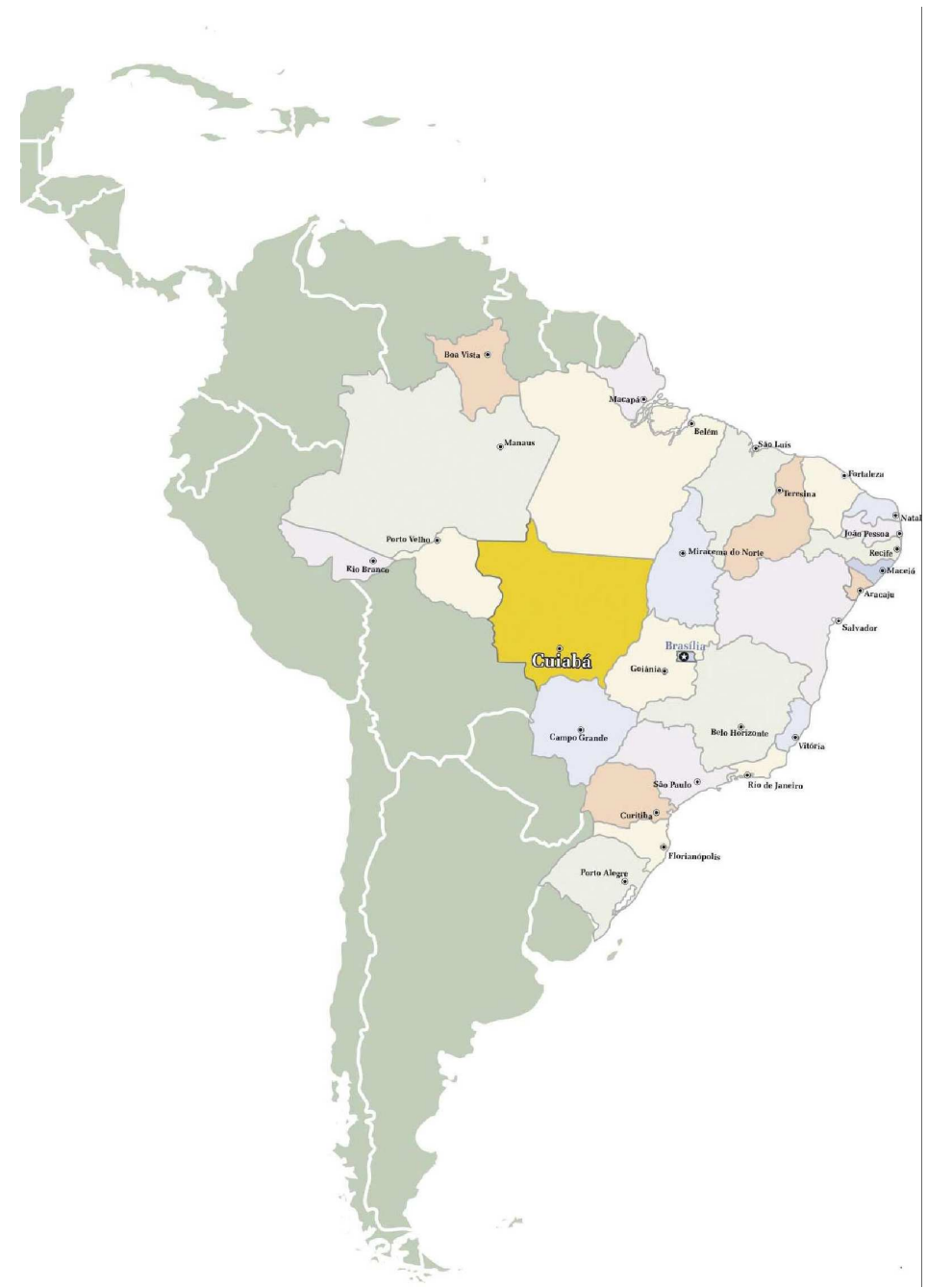

Figura 01: Localização de Cuiabá em relação ao Brasil Fonte IPDU 
Os paulistas (bandeirantes) adentraram o interior com propósitos bem definidos, aprisionar índios e buscar as riquezas naturais da terra, mas, o Brasil só é hoje um país continental porque estrategicamente algumas vilas foram fundadas por eles, e mantidas por Portugal com clara intenção de conquistar novos territórios e, logicamente, suas riquezas. Este foi o caso de Cuiabá, localizada em terras pertencentes aos espanhóis pelo Tratado de Tordesilhas, pela ocupação efetiva, passaram às mãos de Portugal.

Segundo DELSON (1997), "Portugal estipulava que os novos núcleos urbanos deveriam estar localizados próximos das minas de ouro e pedras preciosas, embora considerasse a necessidade de alguns estarem em localizações estratégicas, porque desta forma seria mais fácil fiscalizar a extração de ouro. Cuiabá foi fundada em 1719, pelo bandeirante Pascoal Moreira Cabral que descobriu nas margens do rio Coxipó, lavras de ouro. Algum tempo depois, perto dali, Miguel Sutil descobriu outras lavras nas margens do córrego da Praínha, uma das maiores do Brasil da época. Em 1727, a miserável aglomeração formada por casas simples foi agraciada conforme a lei, com o título de vila portuguesa com o nome de Bom Jesus de Cuiabá. Poderia parecer absurdo, mas a circunstância assim o exigia. Cuiabá era a única aglomeração urbana de toda a região oeste e de tão encravada no sertão, nem sequer constava corretamente em mapas, de forma que era difícil encontrá-la, e mais ainda de se chegar a ela. Então ou os portugueses fundavam outra vila em posição estratégica, ou aparelhavam a já existente. E no momento, optaram por incrementar Cuiabá."

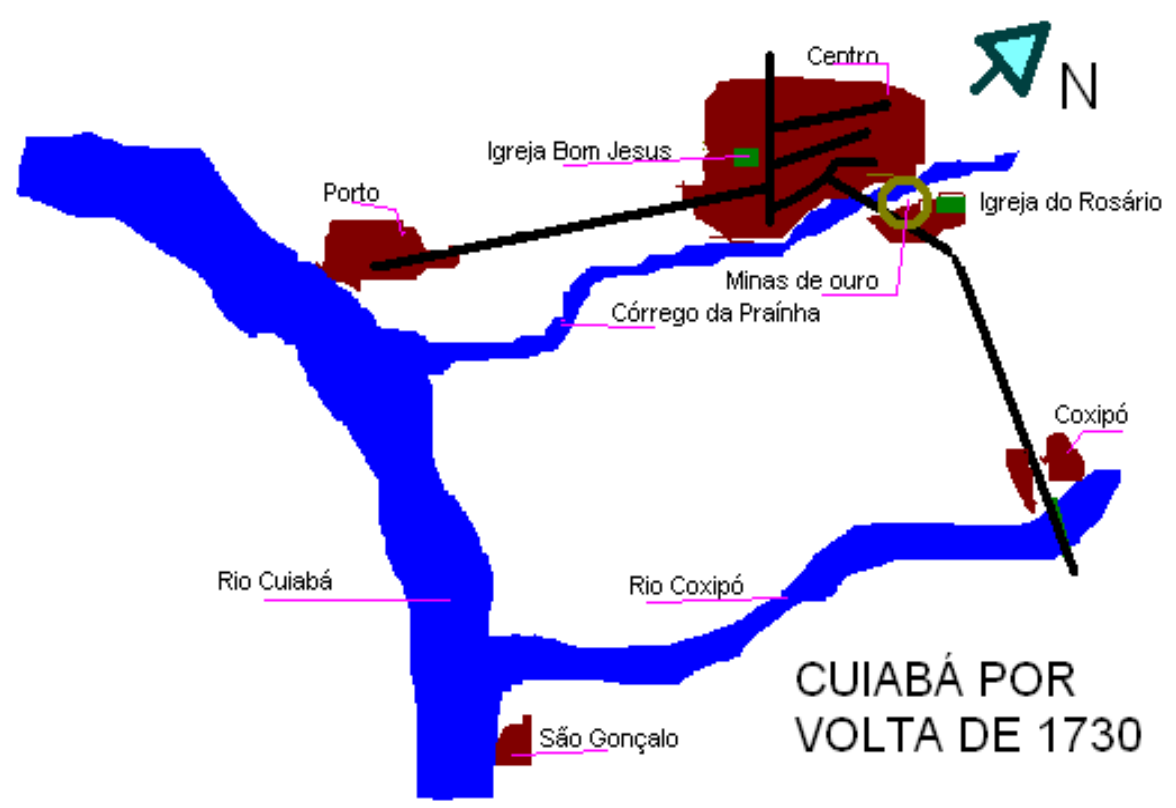

Figura 02 - Desenho ilustrativo de Cuiabá por volta de 1730. 
Isto significou um comprometimento com o desenvolvimento planejado do oeste brasileiro, e para tanto era exigido dos administradores que mantivessem a população escassa na localidade a qualquer custo, sendo exigido registros e censos para o controle.

"Num local plano um pouco acima do córrego foi construída a Igreja Matriz, para os brancos, dedicada a Bom Jesus de Cuiabá, e os escravos, proibidos de freqüentar a igreja dos brancos, construíram a sua, nas proximidades das minas, no morro do Rosário. A capela Nossa Senhora do Rosário foi também dedicada a São Benedito, e até hoje mantém as mesmas características da época. Tempos depois, ainda nas proximidades das minas, construiu-se outra, para os mulatos, e recebeu o nome de Nosso Senhor dos Passos" (MENEZES, 2004). Desde o nascimento fica claro que mesmo em pleno sertão, a divisão de classes já existia assim como a forte religiosidade do povo.

“A cidade tinha como limites na época, a leste o Morro do Rosário, a oeste a colina da Boa Morte, a sudeste, o "morro da luz". Distante 1,5 km das lavras, as margens do rio Cuiabá, foi construído o Porto Geral, criando um novo eixo de expansão rumo ao sudoeste, ao passo que seguindo as curvas de nível do córrego, como era comum nas cidades coloniais da época, surgiram ruas paralelas. O Porto era o único meio de contato com a civilização, por ele chegavam Monções - mercadores que traziam tudo que se podia comprar nas cidades mais litorâneas - o transporte de pessoas, do ouro e outras extrações também eram realizados via fluvial, sendo a navegação, feita pela bacia do Paraguai e do Rio da Prata, o tempo de viagem era de quatro meses aproximadamente, até Porto Feliz em São Paulo” (SIQUEIRA, 1997).

Conforme PREFEITURA DE CUIABÁ (2004), “a povoação do local mostrouse instável ao longo de séculos. Cinco anos após a descoberta das minas, a localidade contava com 3.000 habitantes. Em 1737, já eram 35.000 pessoas, mas as adversidades do local, as doenças, os embates com os índios, o difícil acesso a terras tão interioranas, e o rigor da administração local, fez com que em 1791, contasse apenas com 14.547 habitantes".

Segundo PREFEITURA DE CUIABÁ (2004), “em 1825, Cuiabá foi elevada a capital da província, fato que influenciou profundamente na sua configuração urbanística com a construção de edifícios públicos que enriqueceram o repertório arquitetônico. Em meados do século XIX, o povoado do Porto possuía um comércio mais intenso pela sua localização, além das pousadas e hospedagens, se realizavam 
festejos quando as monções ali chegavam. Nesta época, a localidade se uniu ao povoado de Cuiabá, e juntos contavam com 10.000 habitantes".

"Em 1864, o início da Guerra do Paraguai interrompeu a navegação via rio da Prata, e trouxe sérios transtornos e desabastecimento para a região de Cuiabá que já havia se consolidado como polo comercial e político, passando inclusive a abrigar algumas usinas de açúcar, mas com o isolamento e o declínio das atividades econômicas por que passou, fizeram com que nenhuma modificação urbanística se verificasse por longo período. Isolada, as relações comunitárias se intensificaram e o clima de reciprocidade fez avivar as tradições cuiabanas e a efervescência cultural compensava a estagnação econômica e o isolamento por que passava".

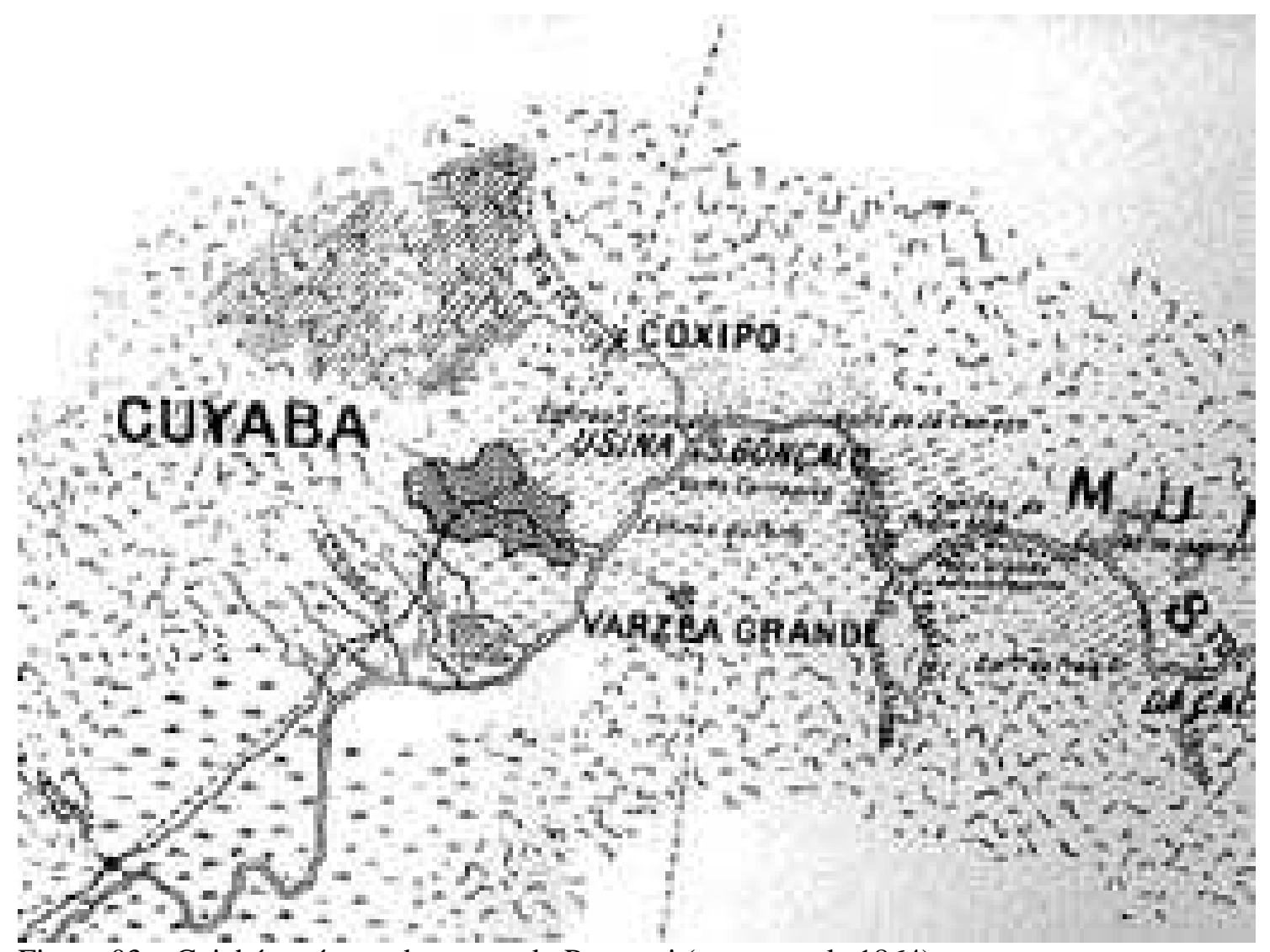

Figura 03 - Cuiabá na época da guerra do Paraguai (em torno de 1864).

Fonte - IPDU

A PREFEITURA DE CUIABÁ (2004), diz que "a guerra, e principalmente seu fim, repercutiu na formação da cidade. Na frente do Porto, na margem direita do rio Cuiabá, formou-se um núcleo urbano a partir da instalação de uma prisão. Nascia assim Várzea Grande, oficialmente fundada em 1867”. 
"Em 1872, pós a Guerra do Paraguai e um surto de varíola, o primeiro censo nacional contou 35.987 habitantes, $51 \%$ da população matogrossense. Em 1890, nova baixa, e o censo contou então 17.815 habitantes, dez anos depois, em 1900 a população dobrara: 34.339 habitantes. Este comportamento instável cedeu lugar à estagnação”.

A PREFEITURA DE CUIABÁ (2004), explica que "no Porto Geral, foi assentado o acampamento militar Couto Magalhães, dando origem no seu entorno a um bairro popular (Don Aquino) de grande densidade populacional no início do século XX. Apesar da política do governo Vargas que através da "Marcha para o Oeste" buscara povoar os sertões brasileiros, as dificuldades ainda eram as mesmas da época do nascimento da cidade, e muitos que chegavam logo se desiludiam ao ver que a promessa de enriquecimento fácil cedia lugar às dificuldades de toda ordem".

"O desenvolvimento começou a ressurgir apenas nos anos 40 do século passado. Com a intervenção governamental, foi aberta uma ampla avenida (Av. Getúlio Vargas) no sentido oeste, que passou a abrigar as repartições públicas, o Grande Hotel, o Cine Teatro, o colégio Estadual de Mato Grosso, e distante um quilômetro, o Batalhão de Infantaria Motorizada. Também foi construída uma estação de tratamento de água mais a noroeste (Av. Presidente Marques), e num ponto um pouco mais distante, nas imediações da Vila Militar, um Campo de Aviação (Av. Miguel Sutil). Na região do Porto Geral, foi construída a ponte Júlio Muller, a primeira ponte de Concreto, ligando Cuiabá a Várzea Grande e facilitando o transporte para a região norte. Em 1945 foram doados terrenos na Av. Getúlio Vargas para a elite cuiabana que nela construíram residências de alto padrão. Em 1948, o poder público municipal propiciou a construção do primeiro conjunto habitacional popular, nas imediações da Av. Getúlio Vargas, consolidando a ocupação desta área”.

Mesmo com este novo impulso, a ocupação era dispersa e segmentada, com um núcleo na localidade do Porto, outro no centro, e mais distante um pouco, a localidade do Coxipó.

Com a construção de Brasília, e da estrada ligando Cuiabá a Porto Velho - RO, Cuiabá assumiu especial importância como centro impulsionador, captando e distribuindo recursos para a economia do norte. Deixou de ser uma Cidade de "fim de linha" para se tornar a medianeira no contexto urbano, regional, e nos projetos de integração nacional da Amazônia meridional, sob o comando do Governo Federal.

A partir da segunda metade do século $\mathrm{XX}$, começou a passar por várias transformações rumo ao desenvolvimento e se consolidar como ponto de apoio da 
economia que ainda possuía base estritamente extrativista e na criação extensiva de gado de corte. Na década de 60, eram 57.860 habitantes, sendo que o grande marco de seu crescimento foi a década de 70, quando, em cinco anos, a cidade passou de 83 mil para 127 mil habitantes.

Para STEINBERGER (2003), “tal explosão vivida nesta época se deveu pela euforia do então "milagre econômico" e do programa de ocupação de fronteiras agrícolas num território de dimensões continentais, que precisava dirimir focos de conflitos e inquietações nas regiões Sul e Sudeste". Então a implantação do modelo capitalista americano, foi adotado sem os cuidados com o ambiente, o patrimônio cultural e a forma peculiar de vida das cidades matogrossenses. A frase "integrar para não entregar", foi a estratégia do governo militar para convocar, como para uma guerra, milhares de cidadãos para ocupar o Norte e o Centro Oeste. Estas regiões eram apresentadas como o novo eldorado, e como sempre, as perspectiva promissoras vinham acompanhadas de muitas dificuldades, de muito trabalho e de falta de todo o tipo de estrutura para se viver. Mesmo assim, muitos realmente melhoraram de vida, mas a maioria da população teve que aprender a lidar com a falta de infraestrutura da localidade.

A partir da década de 60 e em especial a de 70 do século passado, os intensos movimentos migratórios fizeram o crescimento urbano explodir incontrolavelmente, e era intensa a demanda por moradias, infraestrutura e serviços públicos. Mesmo com o surgimento de vários bairros novos, as classes de baixa renda, sem recursos para pagar o preço da moradia, passaram a ocupar a periferia, em terras "griladas" e habitações precárias. Os migrantes, mesmo quando prosperavam, tinham dificuldades para encontrar residências em locais urbanizados fazendo com que os preços do mercado imobiliário disparassem. A economia de Cuiabá que era fortalecida pelo setor terciário (pois a indústria era pouco expressiva) começou a ter impulso devido às indústrias ligadas à agroindústria, que se beneficiaram da construção do Distrito Industrial de Cuiabá, (fomentado por projetos federais para incremento da região). 


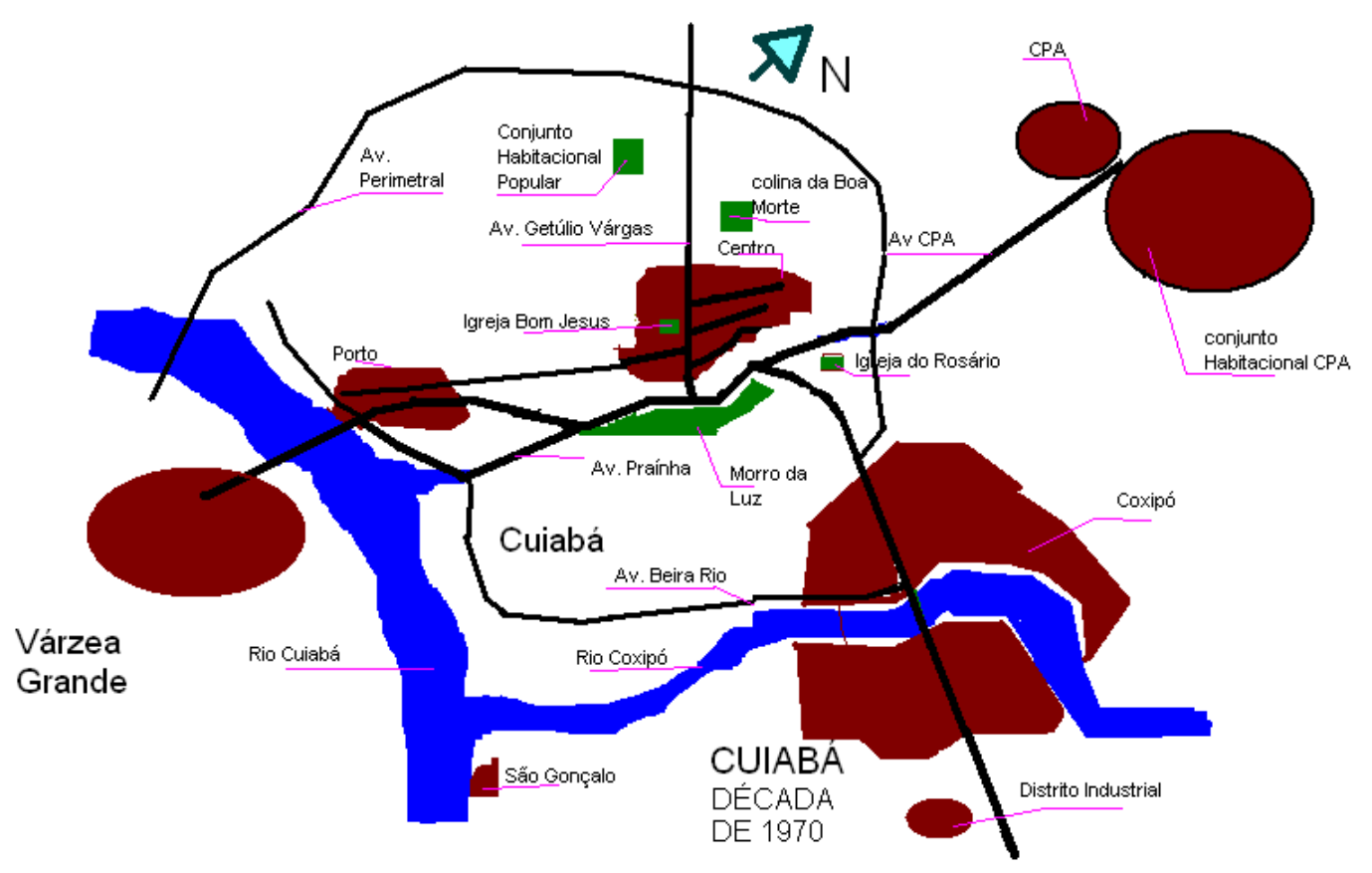

Figura 04 - Esboço de Cuiabá na década de 1970.

Na década de 70, o adensamento do Centro aumentou o trânsito na região, pois as caixas viárias eram incompatíveis com o fluxo do trânsito e ainda, o crescimento do Estado tornou as instalações do Governo, na Praça Alencastro (ao lado da Matriz) insuficientes para os edifícios que ocupava no Centro tradicional. Desta forma, se reservou uma extensa área vazia distante aproximadamente dez quilômetros do centro, até onde foi aberta uma ampla avenida denominada Av. Rubens de Mendonça (Av. do CPA), e ali foi construído o Centro Político Administrativo (CPA), para onde foram transferidas as secretarias do Governo e outros órgãos Federais e Estaduais, num processo de concentração de órgãos públicos que perdura até hoje. $\mathrm{O}$ antigo edifício chamado Palácio Alencastro passou a sediar então a prefeitura municipal. Em 1979, na área ao lado do Centro Político Administrativo, construiu-se grandes conjuntos habitacionais para as classes média- Morada do Ouro - e para a classe baixa - CPAs destinados aos funcionários públicos, (porém nem só eles foram beneficiados).

Desta forma o sítio urbano se ampliava significativamente, rumo ao norte (CPA) e rumo ao sudeste (Av. Fernando Correa), dando largada ao processo de descentralização e formação de novas centralidades. A medida que novos bairros eram implantados pelo Poder Público em localidades cada vez mais distantes do Centro, e necessitando de comércio e serviços por perto, tendo em vista as dificuldades de 
circulação numa malha viária estagnada, servida de transporte público com alto preço para uma população carente.

A história de Várzea Grande tem como o primeiro marco de seu surgimento a antiga estrada boiadeira que saía do Porto no Rio Cuiabá e seguia até as imediações do local onde, hoje, encontra-se o Aeroporto Marechal Rondon. Era usada, em meados do século XIX, por vaqueiros e tropeiros que buscavam a vila de $\mathrm{N}^{\mathrm{a}} \mathrm{Sr}^{\mathrm{a}}$ do Livramento e fazendas da Região de Poconé para pernoitarem e, descansarem o gado vindo de longas jornadas. A topografia oferecia condições adequadas e, ao redor desse local, formou-se, aos poucos, um pequeno povoado conhecido como Várzea Grande.

Durante a Guerra do Paraguai, o povoado perdeu suas características originárias para abrigar um campo de concentração de prisioneiros, passando ao final da guerra, a ser habitado por lavradores, mascates, soldados e presos paraguaios recém-libertos da prisão.

A evolução do povoado foi lenta e, somente na última década do século XIX, com a Proclamação da República, Várzea Grande experimentou um crescimento mais significativo. A partir de 1906 surgiram no município outros povoados como São Gonçalo, Bom Sucesso e Capão Grande, tornando-se em 1911, o Terceiro Distrito de Cuiabá. Mas, somente com a construção da ponte sobre o Rio Cuiabá em 1942 e com a chegada de energia elétrica em 1945, seu crescimento foi alavancado, propiciando sua emancipação política em 1948, quando recebeu os foros de Cidade pela Lei n ${ }^{\circ} 126$ de 23 de Setembro.

Com o acesso facilitado pela ponte do Rio Cuiabá, Várzea Grande aumentou seu comércio com a capital, fornecendo carne, lenha, carvão, materiais para construção (tijolos, areia e cascalho) e grande quantidade de cereais.

Com a instalação da Câmara Municipal em 1949 e a aprovação do Código de Tributos do Município, o Poder Público Municipal pode doar as primeiras áreas de terras para instalação de micro-indústrias e escritórios visando incentivar pequenos empresários. Várzea Grande, graças a este incentivo e ao baixo preço da terra, atrai várias empresas e indústrias e passa a ser conhecida como "cidade industrial".

É na década de 1960 que se acelera o processo de crescimento do município, reforçado nos anos 70 pela política de integração nacional do Governo Federal. Com o incentivo industrial, a cidade passa a receber grande contingente migratório. A construção da BR 163, Cuiabá-Santarém, fazendo de Várzea Grande corredor natural para a Amazônia foi também fator determinante para o constante fluxo migratório, 
provocando grande impacto socioeconômico e cultural. A cidade torna-se então, um dos principais contribuintes para o crescimento da população do Estado, culminando com um dos maiores índices de incremento populacional na década de 70/80, provocando consequentemente descontrolada ocupação do espaço urbano.

Atualmente, o crescimento do aglomerado Cuiabá / Várzea Grande já é bem menor, mas ainda guarda vestígios de épocas passadas preservadas em seu centro histórico, na sua cultura e nas tradições, tão caras para os cuiabanos e Várzeagrandenses que são saudosos de outras épocas.

\section{2- CARACTERÍSTICAS DOS MUNICÍPIOS}

O município de Cuiabá está localizado no Centro Geodésico da América do Sul, é a Capital do Estado de Mato Grosso e possui uma área de $3.538 \mathrm{~km}^{2}$. A cede do município de Cuiabá está a uma altitude de 165 metros e as coordenadas geográficas são $15^{\circ} 35^{\prime} 56^{\prime}$ ' de latitude Sul e $56^{\circ} 06^{\prime} 01^{\prime \prime}$ de longitude de Grenwich.

Cuiabá e Várzea Grande pertencem a Mesorregião Sul - Matogrossense, Microrregião Cuiabá, formada pelos municípios de Cuiabá, Várzea grande, Santo Antônio de Leverger, Nossa Senhora do Livramento e Chapada dos Guimarães. O clima local é o Tropical continental, com médias em torno de $33^{\circ}$ e máximas em torno dos $39^{\circ}$. Possui dois períodos característicos: Um seco (de junho a setembro) e um úmido (de setembro a maio). O bioma a que pertencem as localidades é o Cerrado - pantanal. Cuiabá e Várzea Grande possuem como principais atividades econômicas, o comércio, a prestação de serviços e o principal parque industrial do Estado.

Tabela 1 - Evolução da população.

\begin{tabular}{|l|l|l|l|}
\hline Ano / Localidade & Cuiabá & Várzea Grande & Aglomerado Urbano \\
\hline 1950 & 56.204 & 5.503 & 61.707 \\
\hline 1960 & 57.860 & 11.044 & 68.904 \\
\hline 1970 & 100.860 & 18.146 & 119.011 \\
\hline 1980 & 212.984 & 76.676 & 289.660 \\
\hline 1990 & 380.140 & 151.314 & 531.454 \\
\hline 2000 & 483.346 & 215.298 & 698.644 \\
\hline 2007 & 526.830 & 230.307 & 757.137 \\
\hline
\end{tabular}

Fonte IBGE 2007. 


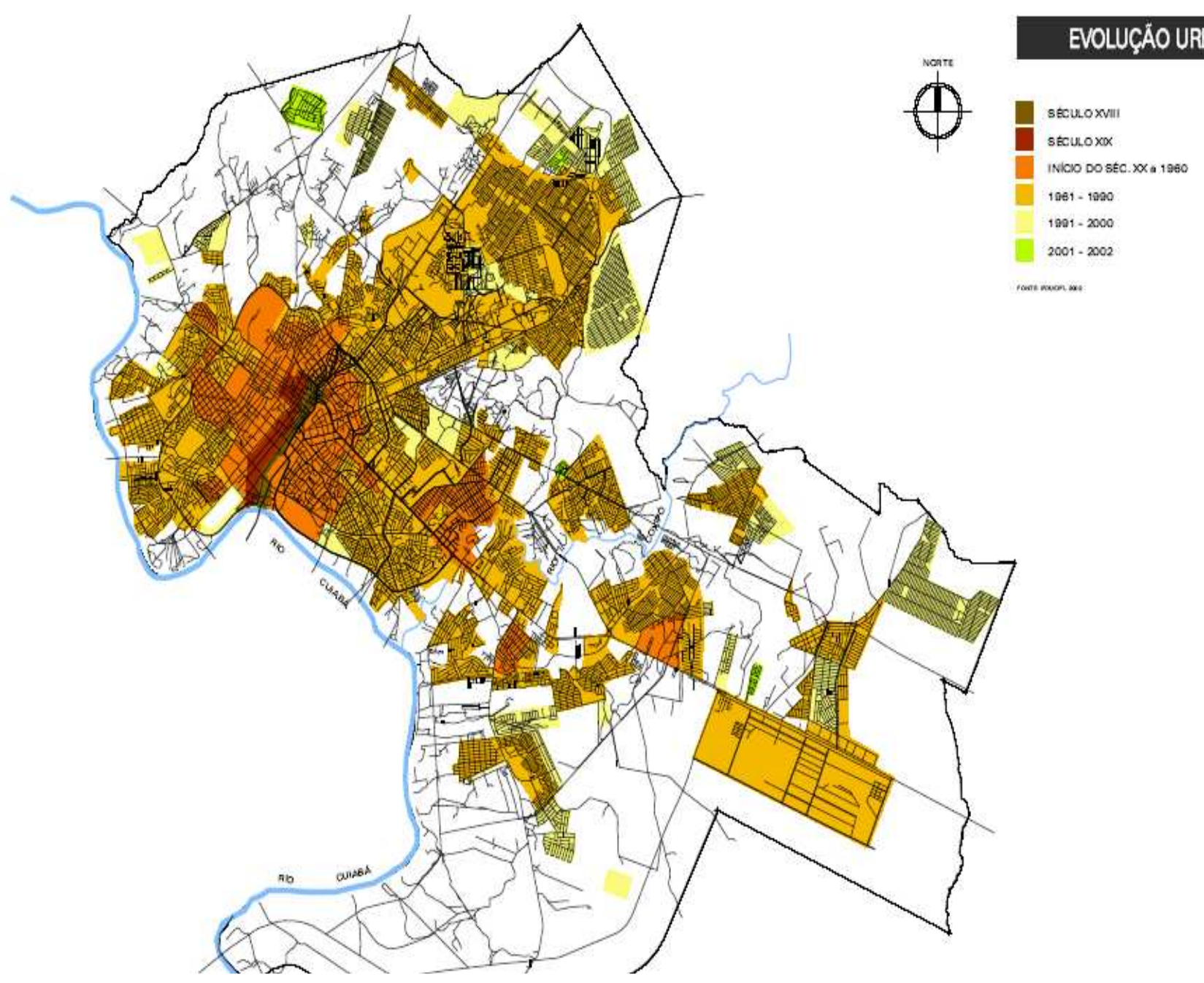

Figura 05 - Evolução Urbana de Cuiabá

Fonte IPDU 2004 


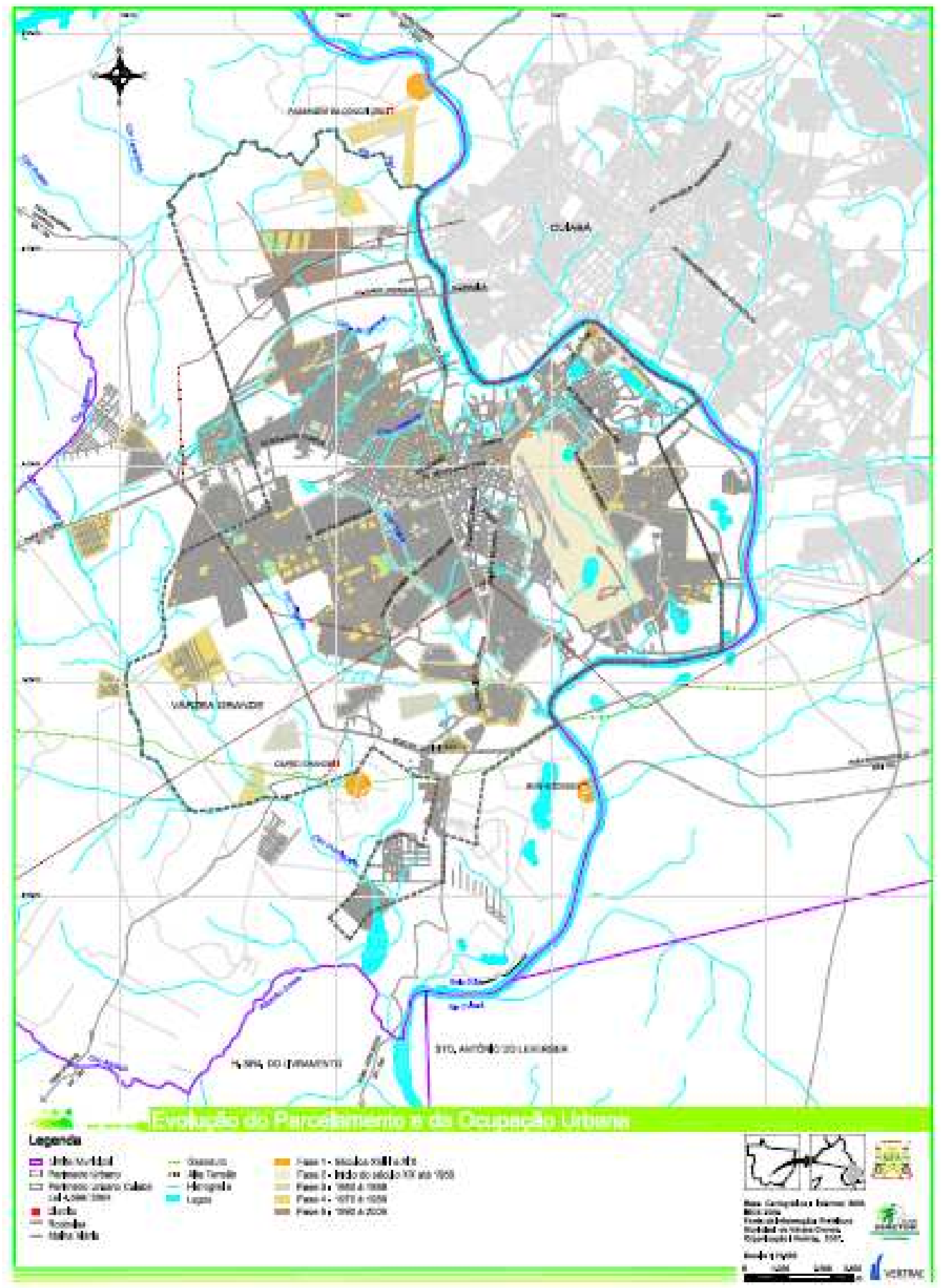

Figura 06 - Evolução do Parcelamento e da Ocupação do Solo em Várzea Grande Fonte - VERTRAG 2007 
Podemos observar que a população de Cuiabá e de Várzea Grande crescia lentamente até o início da década de 1960, e a partir deste período, passou a receber imigrantes de outros Estados. A população praticamente dobrou, comportando-se desta maneira durante as décadas de 1970 e 1980, quando as taxas de crescimento, começam a desacelerar. Atualmente já se percebe redução no crescimento populacional da capital e de Várzea Grande, enquanto paralelamente tem-se o crescimento das cidades do interior do Estado.

Quadro 03 - Rendimento em Cuiabá e Várzea Grande

\begin{tabular}{|l|l|l|l|}
\hline $\begin{array}{l}\text { Cidades/ Rendimento } \\
\text { em (salário Mínimo) }\end{array}$ & Cuiabá & Várzea Grande & Aglomerado Urbano \\
\hline Até 1 & 44.844 & 22.158 & 67.002 \\
\hline Mais de 1 até 2 & 62.220 & 29.919 & 92.139 \\
\hline Mais de 2 até 3 & 31.075 & 14.533 & 45.608 \\
\hline Mais de 3 até 5 & 34.689 & 14.834 & 49.523 \\
\hline Mais de 5 até 10 & 34.850 & 10.454 & 45.304 \\
\hline Mais de 10 até 20 & 16.570 & 3.595 & 20.165 \\
\hline Mais de 20 & 10.810 & 1.390 & 12.200 \\
\hline Sem rendimento & 158.946 & 73.850 & 232.796 \\
\hline Com rendimento & 235.061 & 96.883 & 331.944 \\
\hline
\end{tabular}

Fonte IBGE - 2001.

Conforme A tabela 02 se vê que é grande o número de pessoas vivendo com rendimentos até três salários mínimos, e sem rendimento.

A figura 05 indica que as menores rendas estão concentradas na periferia, em localidades desconectadas da malha urbana (em amarelo e amarelo claro) e as maiores rendas concentram-se em bairros adjacentes à Avenida Miguel Sutil, conhecida como Perimetral e que contorna o centro da cidade.

Observa-se que os bairros populares e periféricos como o CPA e os de baixa e média baixa renda, (inclusive o centro e os antigos bairros nas proximidades do Porto) são os mais densos. 


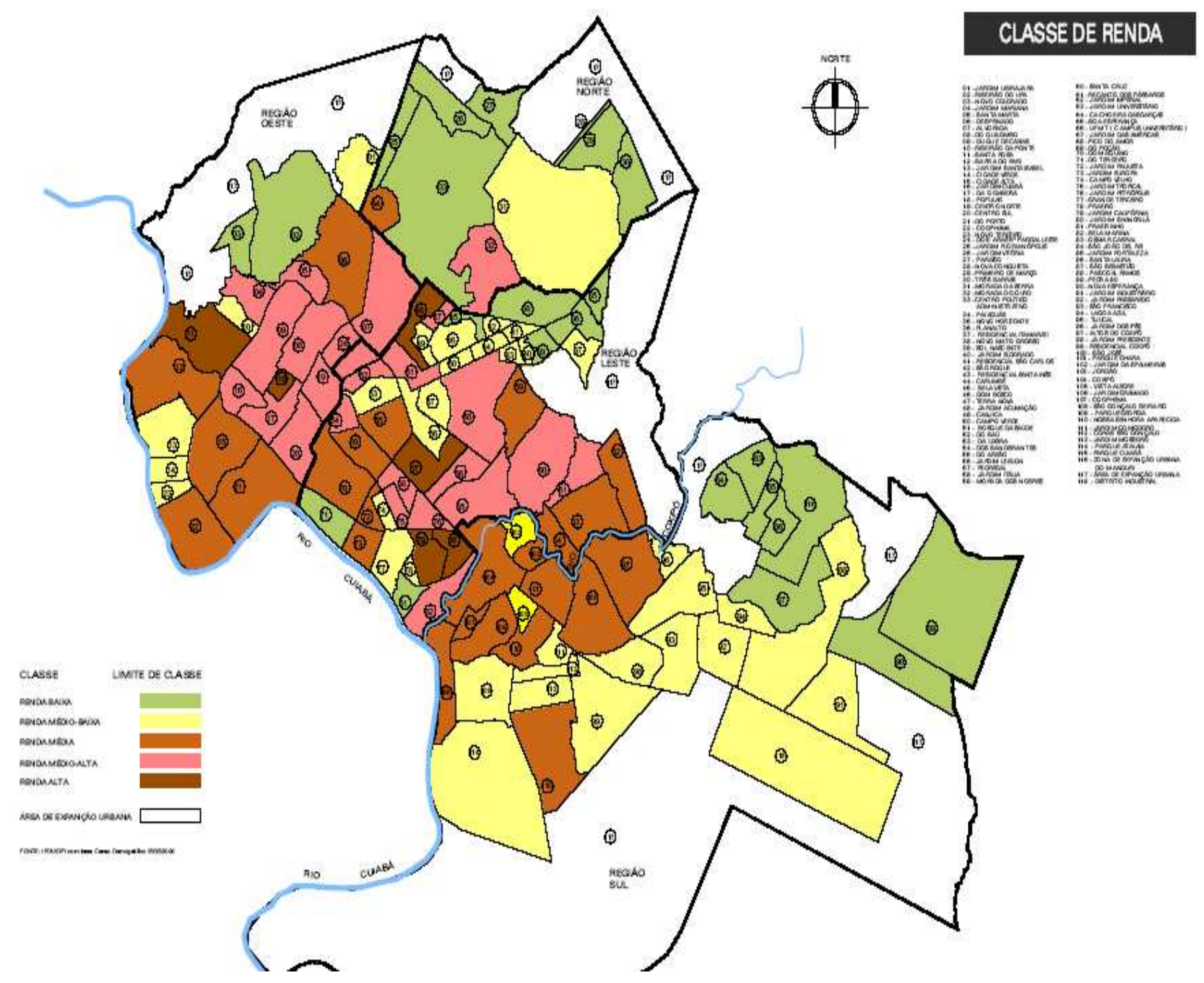

Figura 07 - Classe de renda em Cuiabá

Fonte:IPDU2004 


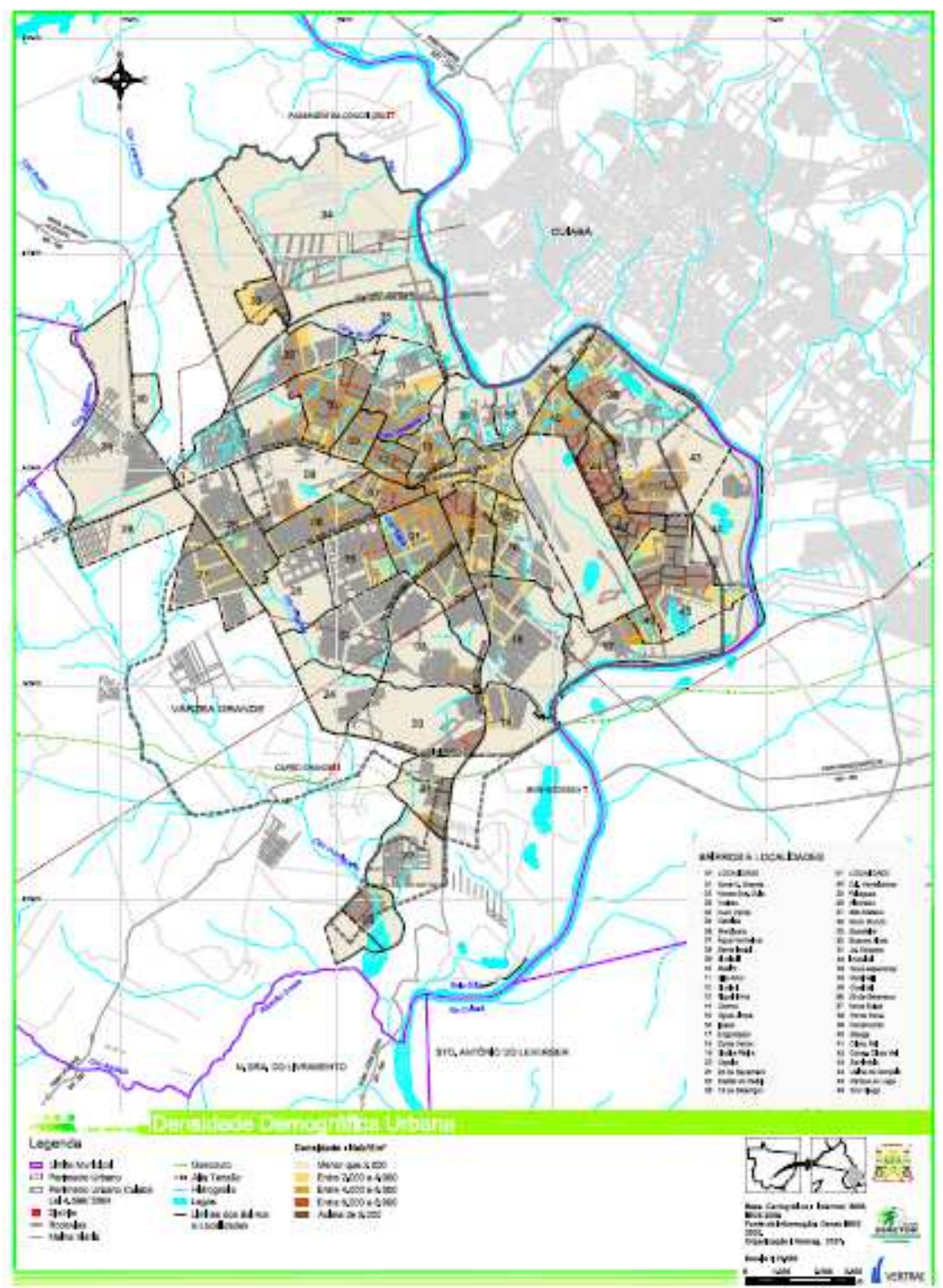

Figura 08 - Densidade Demográfica de Várzea Grande Fonte VERTRAG 


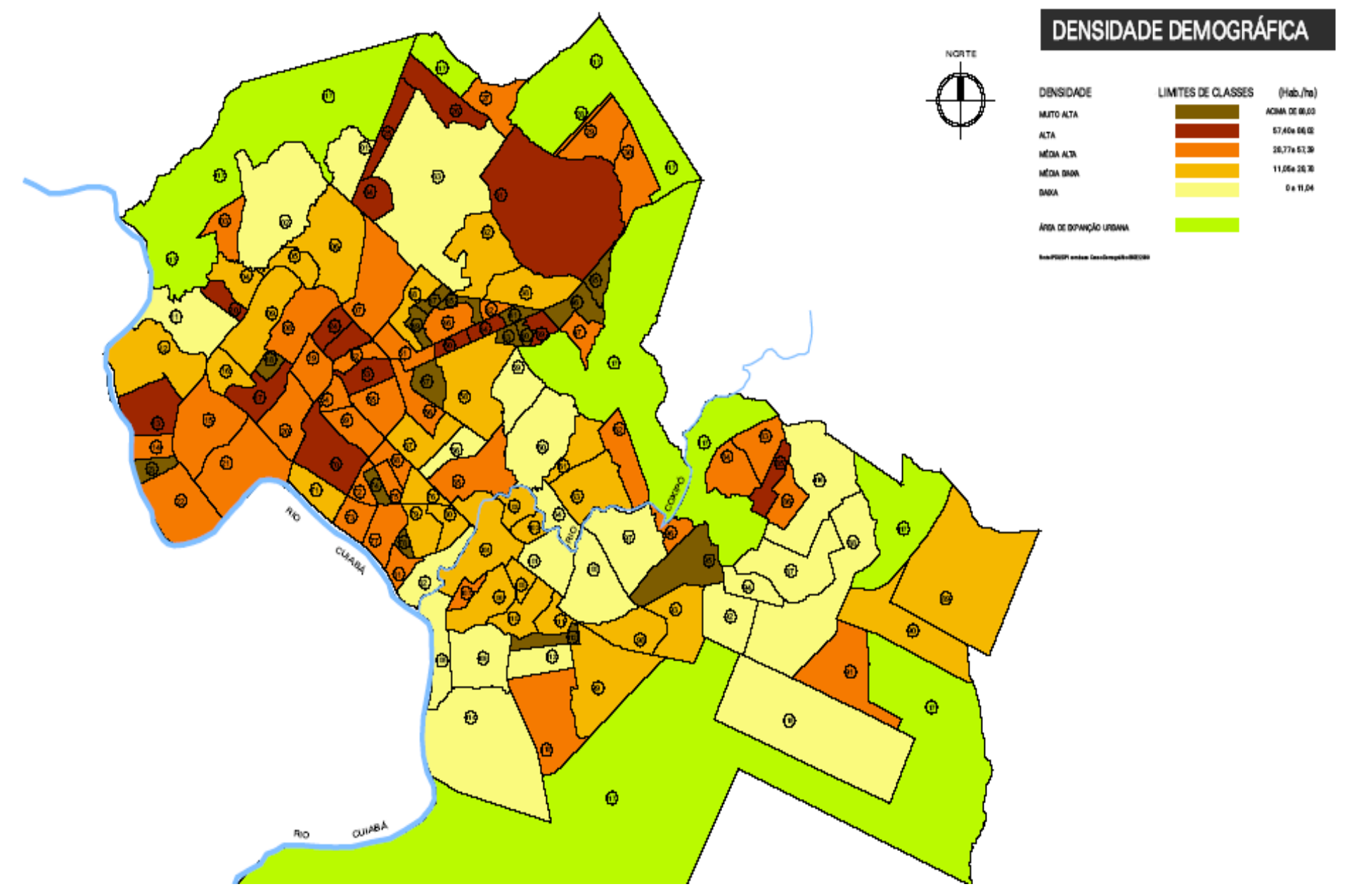

Figura 09 - Densidade Demográfica de Cuiabá Fonte IPDU 2004 
Os mapas existentes e disponíveis nas prefeituras não costumavam apresentar ambos os municípios, mostravam a sua cidade como se nada existisse do outro lado do rio sendo os atuais de Várzea Grande vagamente apresentam a malha viária vizinha. Este fato influencia no planejamento urbano dos municípios, pois acaba dificultando a visualização do que está acontecendo do outro lado do rio. A malha urbana que liga os municípios é desarticulada, de forma que existem poucas ligações (apenas cinco pontes) entre eles. Isto provoca a estagnação das principais ligações, com freqüentes "engarrafamentos" e transtornos para os munícipes. Observa-se que as cidades possuem grandes áreas vazias desarticulando o tecido urbano.

Os principais problemas urbanos de Cuiabá e Várzea Grande são a falta de água e esgoto, a destinação (ainda inadequada) dos resíduos sólidos, as questões ambientais, principalmente ligadas ao Rio Cuiabá, o sistema viário que ano a ano vem se tornando saturado e insuficiente para a atual população, a falta de moradia e os problemas fundiários referentes à quantidade de bairros que continuam clandestinos ou ilegais (estima-se que $70 \%$ das habitações da cidade tenham algum problema legal) e a violência urbana, que tem crescido assustadoramente no aglomerado urbano.

\section{3- O PLANEJAMENTO URBANO EM CUIABÁ E VÁRZEA GRANDE}

A cidade de Cuiabá nasceu sem planejamento. Suas ruas tortuosas acompanhavam a topografia, moldando-se naturalmente ao terreno, como acontecia nas cidades fundadas pelos portugueses. Da mesma maneira foi aumentando, de forma que a abertura das ruas seguia apenas uma lógica: a de responder às necessidades imediatas, principalmente a de ligar os pequenos aglomerados de casas esparsos e, por isso, o tecido urbano não era contínuo, possuía muitos recortes. E assim foi durante muito tempo.

O padrão só foi quebrado a partir de 1940, pela efetiva intervenção do Poder Público, época em que a modernização e a abertura de vias, a construção de alguns edifícios públicos, e o embelezamento da cidade, mudaram a estrutura e a paisagem urbana. Foi a época das intervenções com intenção de tornar a cidade "bela", conforme já ocorria em outras capitais.

Na década de 1960, o Governo Estadual começou a ser pressionado pela intensa migração, e os serviços públicos e principalmente a falta de habitação fez com que várias medidas fossem tomadas, entre elas a criação da COHAB (Companhia de 
Habitação Popular do Estado de Mato Grosso). A COHAB foi responsável pela implantação de diversos conjuntos habitacionais que direcionaram o crescimento da cidade, também contribuiu para isto, o asfaltamento da Avenida Fernando Correa da Costa e a implantação no Coxipó da Universidade Federal de Mato Grosso, direcionando para Sudeste o crescimento da cidade. Para formar um anel viário, foram construídas as Avenidas Beira Rio e a Miguel Sutil (Perimetral).

Na década de 1970, a cidade já não comportava em seu centro alguns serviços, e o governo estadual mudou sua sede para a região Norte da cidade, na localidade conhecida como CPA (Centro Político Administrativo) onde ao lado foram construídos pela Cohab, no final da década conjuntos habitacionais populosíssimos, ambos ligados ao centro por uma larga via estrutural da cidade, a Avenida Rubens de Mendonça (Av. do CPA).

Então, até meados da década de 1970, o planejamento urbano de Cuiabá se deu baseando-se em trabalhos setoriais realizados por técnicos da prefeitura, especialmente voltado para o sistema viário, ao paço que obras realizadas pelos governos estaduais e federal direcionavam o crescimento da cidade.

Em 1974 Cuiabá já contava com um Plano de Desenvolvimento Local Integrado - PDLI, e uma vasta legislação urbanística como Lei de Zoneamento e Parcelamento do Solo Urbano, Lei do Perímetro Urbano e um Código de Obras. Tudo aos moldes da SERFHAU (Serviço Federal de Habitação e Urbanismo) e, como na maioria das cidades brasileiras, as propostas contidas neste Plano não foram implementadas. (site do IPDU)

No início da década de 1980, segundo o site do IPDU, um grupo de trabalho sob orientação da Fundação Prefeito Faria Lima se reuniu com o objetivo de elaborar a legislação urbanística básica para a cidade, resultando nas Leis $\mathrm{N}^{\circ}$ 2.021/1982 (Lei de Parcelamento do Solo), Lei No 2.022/82 (sobre construções, reformas e ampliações), e a Lei 2.023/1982 (sobre o uso do solo urbano). Entre 1983 e 1985, uma equipe de técnicos da prefeitura formou a denominada Unidade Administrativa do Sub-projeto UAS cuja origem era o projeto Aglomerado Urbano AGLURB, vinculado ao Programa de apoio às Capitais e Cidades de Porte Médio. A estrutura foi desativada em 1986 deixando, contudo, um considerável acervo técnico com inúmeras informações sobre o município. Os problemas se avolumavam e respondendo à pressão de diversos organismos como IAB (Instituto Brasileiro de Arquitetos), SINDUSCOM (Sindicato dos Trabalhadores da Construção Civil) e CREA/MT (Conselho Regional de 
Arquitetura, Engenharia e Agronomia) entre outros, em meados de 1984 a Câmara Municipal de Cuiabá criou a “Comissão Cuiabá 2000”. Foram realizadas inúmeros seminários, palestras e discussões sobre a política urbana municipal, assim a participação da sociedade organizada começava a despertar em Cuiabá. (site do IPDU).

Os debates resultaram na Lei No 2.259 de 26/04/1985, que autorizou a criação do IPDU (Instituto de Pesquisa e Desenvolvimento Urbano) visando garantir o planejamento urbano contínuo em Cuiabá.

Em 1987, foi instituído na Prefeitura o grupo de Trabalho do Plano Diretor Urbano com o objetivo de elaborar estudos técnicos sobre a cidade e desenhar a estrutura do IPDU, que ainda não havia efetivamente se constituído. Os trabalhos resultaram na promulgação do Decreto № 1.728/1987 criando o IPDU, e em 1988, e as Leis 2.645 e 2.646, estruturaram o IPDU e instituíram a Política Municipal de Desenvolvimento Urbano, implementada pelo Sistema Municipal de Desenvolvimento Urbano.

O plano diretor, a cargo do IPDU foi iniciado em 1990, tendo sido a estrutura e o conteúdo estabelecidos pela lei orgânica Municipal, sendo que este foi concebido para ser implantado em etapas que segundo CHILLETO (2005), “... duraram mais do que o previsto e somente foram realmente concluídas em 2003, devido a sucessivas discussões com a sociedade".

Através da Lei 2.852/1991 foi organizado o Sistema Municipal de Desenvolvimento Urbano - SMDU, e criado o Conselho Municipal de Desenvolvimento Urbano - CMDU, órgão colegiado com poderes deliberativos, consultivo e recursal, devendo acompanhar e avaliar a execução da política urbana. Nesta época foram concluídas as diretrizes básicas do Plano Diretor de Desenvolvimento Urbano elaborado com a participação de técnicos da prefeitura, de professores da Universidade Federal de Mato Grosso (através de convênio) e de consultores contratados. Após finalização do projeto de lei, este foi apresentado para a comunidade e discutido no Conselho Municipal de Desenvolvimento Urbano para a sua aprovação junto a Câmara de vereadores. Várias entidades se mobilizaram como o IAB e SINDUSCOM, resultando na Lei Complementar N ${ }^{\circ}$ 003/1992 assim como a Lei para o Gerenciamento Urbano, Lei Complementar No 004/1992, que instituiu o Código de Postura do Município, o Código do Meio Ambiente e recursos Naturais, e o Código de Obras e Edificações. (site IPDU). 
A Política de Desenvolvimento Urbano adotada pela prefeitura de Cuiabá durante a década de 1990 visou o ordenamento das funções sociais da cidade, e seu texto contém como objetivo tudo aquilo que se espera de uma cidade igualitária para todos (direito do cidadão à saúde, educação, moradia, transporte coletivo, segurança, qualidade de vida e tudo mais). Mas na prática, não é bem isso que acontece, de forma que persistem os problemas urbanos comuns a todas as cidades brasileiras, e os esforços para pôr em prática as ações ainda não se concretizaram a contento. No entanto não se pode negar que nesta década já se consolidava a participação social na elaboração de política urbana e muitas inovações foram adotadas na legislação de Cuiabá, especialmente em alguns instrumentos hoje consagrados no Estatuto da Cidade, foram debatidos e utilizados com muita polêmica pela legislação municipal na década de 1990.

O município de Várzea Grande foi sendo conduzido pelo Poder Público de forma alheia a qualquer tipo de planejamento urbano. Esta palavra não existia nem sequer no discurso, não era exigido pela população, nem pelos políticos, nem pelos empresários e nem por técnicos da prefeitura. Problemas urbanos existiam muitos, mas era impensável que o planejamento urbano fosse capaz de alguma solução, já que o que interessava para os munícipes era a obra e a resolução imediata de seu problema (deveria então ser tratada diretamente com secretários ou com os vereadores). Desta forma, a secretaria de Viação, Obras e Urbanismo (este urbanismo quer dizer obras no setor urbano, não planejamento) concentrou todos os assuntos referentes aos aspectos físicos da cidade.

Até meados da década de 1990, era na secretaria de obras que se tratava do "patrolamento" das numerosas ruas sem pavimentação, que se tratava do asfalto, da abertura de vias, da construção e conserto das pontes (de madeira) das estradas vicinais, que se projetava, orçava e fiscalizava obras de edifícios públicos de toda a natureza, inclusive suas reformas, onde se faziam os projetos viários relativos ao trânsito. Cuidava de transporte público urbano (inclusive de tarifa e de linhas dos ônibus), onde se aprovava projetos e loteamento, e cuidava-se de habitação popular, entre outras questões que por não ter órgão para cuidá-las, acabavam sendo tratadas na secretaria de obras, (como foi o caso do plano diretor, elaborado no início de 1990). Apesar de tantos afazeres, o corpo técnico era bastante reduzido.

Quando a Constituição Federal do Brasil foi aprovada, foi exigida a elaboração de plano diretor para cidades maiores que vinte mil habitantes. Várzea Grande já contava com aproximadamente cento e cinquienta mil habitantes, embora continuasse 
com uma estrutura administrativa bastante modesta. Sem técnicos suficientes e capacitados, contratou-se uma pequena equipe, encabeçada por um professor da Universidade Federal de Mato Grosso que possuía alguma experiência, e alguns técnicos (cuja formação era a engenharia florestal), a quem se juntaram um engenheiro civil, um geógrafo e um arquiteto. Estes se instalaram em uma sala da Secretaria de Obras e escreveram o plano diretor do município de Várzea Grande, no modelo modernista, com um forte viés ambiental, e várias exigências que não tinham como ser cumpridas.

Este documento foi desmembrado e deu origem a Lei $\mathrm{n}^{\circ} 1.266 / 92$, o Plano Diretor que foi devidamente engavetado e ninguém sabia de sua existência (e se sabia, não comentava) nem dentro da prefeitura, até a Procuradoria Municipal informava aos técnicos que plano diretor não existia.

O que se sabia que existia, e eram mencionadas sempre eram: a lei $n^{\circ} 1389 / 1994$, tratando de Zoneamento, Loteamento, Código de Obras e Sistema Viário, e a Lei $\mathrm{n}^{\mathrm{o}}$ 1497/1994 instituindo o Código de Meio Ambiente e recursos Naturais, (sendo que estas leis sofreram algumas alterações feitas pela Lei $N^{\circ}$ 2.404/2002). No entanto, a reclamação dos técnicos quanto à inaplicabilidade da legislação urbanística (por razões técnicas e principalmente, por razões políticas) sempre foi geral.

Em meados da década de 1990, os assuntos de transporte coletivo e trânsito passaram a ser "cuidados" por uma coordenadoria vinculada à Secretaria de Serviços Públicos, e em 1997, foi instituída a Superintendência de Transporte e Transito de Várzea Grande, pois o assunto demandava cada vez mais cuidados, e a estrutura anterior era inadequada.

Em 2001, foi criada uma Assessoria Especial que embora funcionasse nas dependências da Secretaria de Obras (e utilizasse técnicos desta), possuía poderes independentes, sendo ligada diretamente ao prefeito. Sua atribuição era cuidar dos convênios da Prefeitura junto ao Governo Federal, e especialmente para elaborar e angariar recursos para alguns projetos urbanísticos, cujo financiamento advinha do Orçamento Geral da União (OGU) e do projeto Habitar do Banco Internacional de Desenvolvimento (Habitar BID, com a intenção de urbanizar assentamentos subnormais no município), entre outras medidas relacionadas à infra-estrutura de bairros carentes.

Esta Assessoria Especial, de certa forma, mostrou as dificuldades que o município vinha passando por não ter um órgão que cuidasse de forma prioritária das questões urbanas, inclusive do planejamento urbano, pois foram enormes as 
dificuldades para conseguir informações das outras Secretarias, pois não existiam mapas atualizados, nem estatísticas nem informações confiáveis, tendo em vista que a prefeitura não estava sequer razoavelmente informatizada (em pleno século XXI se desenhava com caneta nanquim no Setor de Projetos).

Quando o Estatuto da Cidade instituiu que os planos diretores fossem revisados para absorverem seus princípios e objetivos, esta revisão ficou a cargo da Secretaria de Planejamento, que lamentavelmente não possuía nenhuma tradição em lidar com as questões urbanas, sem nenhum conhecimento do que se passava em termos físicos no município. Sem corpo técnico, buscou apoio na Secretaria de Obras, que já participava do Núcleo de apoio aos planos diretores do Estado de Mato Grosso, e da Câmara Setorial de Habitação e Urbanismo do Aglomerado Urbano Cuiabá / Várzea Grande. Por sorte, a prefeitura já contava com recursos aprovados junto ao Ministério das Cidades para a contratação de consultoria para auxiliar na elaboração do plano diretor participativo, o que acabou acontecendo.

A falta de estrutura adequada voltada para o planejamento urbano e para as questões voltadas para habitação popular e acesso à terra em Várzea Grande, tem causado grandes problemas, disputas internas dentro da estrutura administrativa da prefeitura e, consequentemente, perdas para a população, na busca do direito à cidade e na melhoria da qualidade de vida. 


\section{CAPÍTULO 3 - O AGLOMERADO URBANO CUIABÁ - VÁRZEA GRANDE}

\section{1- CRIAÇÃO E ESTRUTURAÇÃO}

A Constituição Federal de 1988 dispões no Art. 25, parágrafo 3º que os Estados poderão criar aglomerados urbanos e regiões metropolitanas, quando ocorresse entre os municípios vizinhos um processo de conurbação ou quando as relações de integração funcional e interação socioeconômicas tornassem necessário o planejamento conjunto em alguns assuntos, do mesmo modo também autoriza o Art. 302 da Constituição Estadual. Tendo em vista a ocorrência desta urbanização, e o total relacionamento entre a capital, Cuiabá, e sua vizinha, Várzea Grande, o Governador do Estado criou por meio da Lei Complementar $N^{\circ}$ 83, de maio de 2001, o Aglomerado Urbano (AGLURB) abrangendo as duas cidades.

Como dispõe a Constituição e a Lei 83 de 2001, os municípios não perderam sua autonomia política, administrativa e financeira, mas teriam que sentar-se à mesa para discutirem seus principais problemas e projetos, de forma que as ações (ou falta de ação) de um não viessem a prejudicar o outro, assim estaria se propiciando a oportunidade de se estabelecer políticas públicas que viesse ao encontro dos interesses gerais dos munícipes de ambos os lados do Rio Cuiabá.

$\mathrm{O}$ reconhecimento da necessidade de se estabelecer uma harmonia quanto às ações e às políticas referentes a estas localidades não é, contudo, novidade, pois data de 1993 a Lei Complementar ${ }^{\circ} 28$ que criou pela primeira vez o Aglomerado Urbano Cuiabá - Várzea Grande. Esta lei, segundo CHILETTO (2005), “definiu a composição inicial que foi mantida pela lei atual ${ }^{4,}$. No ano de 1999, a Lei Complementar $n^{\circ} 28$ sofreu uma pequena alteração para que fossem incluídos no Conselho Deliberativo, os representantes da Assembléia Legislativa, a criação da Câmara Setorial de Meio Ambiente e extinção da Câmara Setorial de Serviços. Estas duas Leis foram revogadas pela Lei atual.

O Aglomerado Urbano a princípio se vinculou à Secretaria Extraordinária de Projetos Estratégicos. Em 2002, passou à Secretaria de Estado de Planejamento e

\footnotetext{
${ }^{4}$ A Lei Complementar $n^{\circ}$ 28/1993 instituiu o conselho deliberativo e algumas câmaras setoriais como a de Indústria, Comércio, Turismo e Mineração, a de Transportes,a de Serviços, a de Saúde e Educação, a de Agricultura e Abastecimento e a de Habitação e Urbanismo.
} 
Coordenação geral (SEPLAN), em 2003 retornou à Casa Civil, e em 2005 retornou à SEPLAN. Estas mudanças dificultaram as ações do AGLURB tanto junto ao corpo técnico dos órgãos aos quais se vinculou como junto à população.

O AGLURB se estruturou de forma a ter um Conselho Deliberativo, uma Secretaria Executiva e as Câmaras Setoriais.

O Conselho Deliberativo funcionava (até a instituição da Região Metropolitana) de forma colegiada, com inúmeras atribuições destacando-se:

- Promover o desenvolvimento integrado dos municípios limítrofes, compreendendo várias instâncias como a Municipal e Estadual e a sociedade organizada. (Art. $7^{\circ}$, Inc. I);

- Estabelecer planos, programas e projetos de interesse comum aos municípios envolvidos. (Art. $7^{\circ}$, Inc. II);

- Aprovar objetivos, metas e prioridades consideradas de interesse comum entre os municípios, segundo objetivo de todos os entes políticos envolvidos. (Art. $7^{\mathrm{o}}$, Inc. III);

- Encaminhar propostas de caráter intermunicipal para serem incluídas nos PPAs, LDOs e LOAs dos Municípios. (Art. $7^{\circ}$, Inc.V);

- Propor ao Estado e aos Municípios altercações de natureza tributárias, de caráter extra fiscal para desenvolvimento das localidades. (art. $7^{\circ}$, Inc. VI);

- Sugerir a desapropriação de bens declarados de utilidade pública. (Art. $7^{\circ}$, Inc. IX);

- Deliberar sobre quaisquer matérias de impacto intermunicipal. (Art. $7^{\circ}$, Inc. $\mathrm{XI})$;

- Aprovar a integração de outros municípios nas Câmaras Setoriais ( Art.7º, Inc. XIII).

O Conselho Deliberativo se compunha dos seguintes membros:

I- O Governador do Estado;

II- 02 (dois) representantes da Assembléia Legislativa do Estado;

III- O prefeito de Cuiabá;

IV- O prefeito de Várzea Grande;

V- 02 (dois) representantes da Câmara de Cuiabá;

VI- 02 (dois) representantes da Câmara de Várzea Grande; 
VII- 06 (seis) representantes de entidades não governamentais de cada município.

Os membros do Conselho possuíam mandato de um ano, não eram remunerados e as reuniões previstas para acontecer pelo menos de quatro em quatro meses, porém "o Conselho encontrava várias dificuldades para sua atuação, pois como dependia da convocação do seu Presidente ou de algum conselheiro - conforme o Regimento Interno do AGLURB - estas reuniões não aconteciam com a freqüência disposta na Lei, frustrando assim a atuação das Câmaras Setoriais, que viam suas propostas não serem levadas a diante, o que causava prejuízos aos debates, ao planejamento e à gestão do AGLURB”. (CHILETTO, 2005).

Constituíam ações promovidas pelo Conselho Deliberativo, segundo CHILETTO (2005) "a contratação do Plano Integrado do Transporte Coletivo para o Aglomerado urbano, onde se detalham os problemas e foram sugeridas melhorias para o transporte intermunicipal, e a instituição de Comissões Técnicas ${ }^{5}$ para a solução de diversos problemas levantados e a elaboração de projetos visando uma atuação em conjunto entre as cidades."

A Secretaria Executiva tinha como principais finalidades:

- A administração geral do Conselho Deliberativo, a assistência, o assessoramento e a representação - quando designado - do seu presidente. (Art. 14, Inc. I, II e IV);

- Coordenar a elaboração de relatórios periódicos do Conselho, divulgar informações sobre as atividades, organizar os arquivos. (Art. 14, Inc.VI,VII e VIII);

- Desempenhar outras tarefas definidas no regimento interno. (Art. 14, Inc.X).

O Secretário(a) era sempre indicado pelo Presidente do Conselho Deliberativo (no caso o Governador do Estado).

Além do Conselho Deliberativo e da Secretaria Executiva, a Lei estabeleceu dez Câmaras Setoriais, que são órgãos de assessoramento compostos por técnicos das

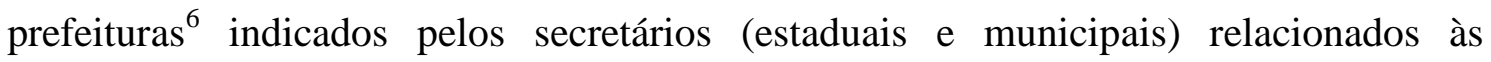

\footnotetext{
${ }^{5}$ Instalaram-se vária Comissões Técnicas, sendo elas: 1)de acompanhamento das atividades Mineradoras no rio Cuiabá, e aproveitamento dos recursos minerais do Aglomerado Urbano; 2) Para elaboração do Projeto do Sistema Cartográfico com Informações Georeferenciadas do AGLURB; 3)Projeto de sistema para verificação de Óbitos; 4) Projeto do Sistema Integrado de Inspeção Sanitária do AGLURB; 5) Comissão técnica para elaboração de Projeto da Central de Abastecimento do AGLURB.

${ }^{6}$ Cada Câmara Setorial é composta por dois membros e dois suplentes de cada prefeitura e do Estado totalizando seis titulares e seis suplentes.
} 
Câmaras Setoriais, devendo a lista com os nomes dos técnicos ser enviada pelo Governador e pelos Prefeitos. O coordenador e o relator de cada Câmara são eleitos pelo grupo, e as reuniões ocorrem pelo menos uma vez por mês (o que nem sempre acontece), segundo um calendário elaborado pela Secretaria Executiva e dependendo do assunto a ser tratado, pode haver reuniões conjuntas. Segundo o regimento interno, as Câmaras Setoriais eram:

I- Indústria Comércio e Mineração;

II- Meio ambiente;

III- Trânsito e Transporte

IV- Serviços Públicos;

V-Saúde;

VI- Educação e Cultura;

VII- Agricultura e Abastecimento;

VIII- Habitação e Urbanismo

IX- Turismo

X-Segurança Pública.

Cabia às Câmaras Setoriais, segundo o Art. 16 da Lei 83/2001, principalmente:

- Elaborar estudos e análises de projetos, emitirem pareceres sobre projetos encaminhados pelo Conselho Deliberativo (Inc. I)

- Elaborar estudos e levantamentos de dados para execução de programas, conforme as diretrizes do AGLURB. (Inc. I). 


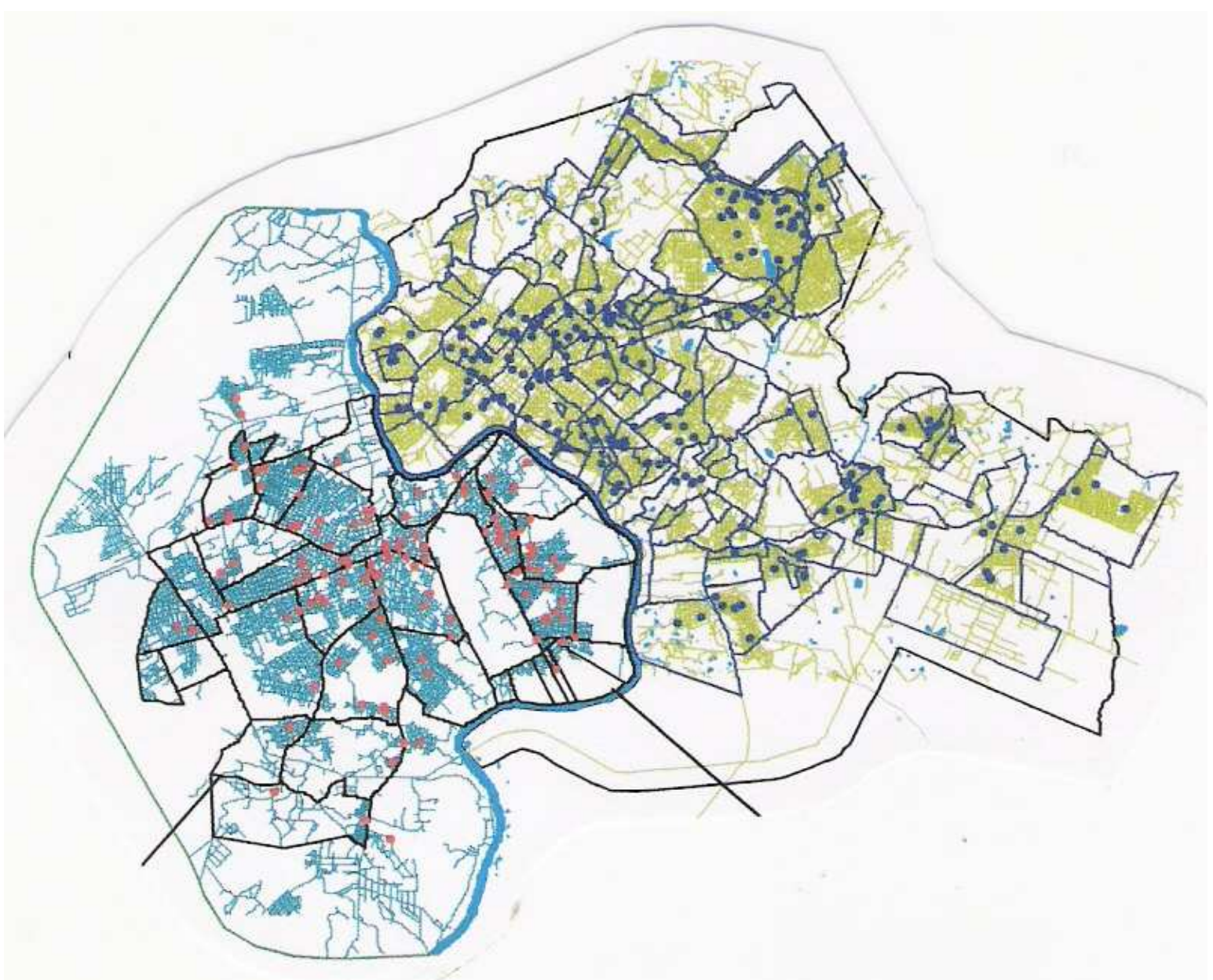

Figura 10 - AGLURB (Aglomerado Urbano Cuiabá Várzea Grande)

Fonte: SEJUSP - MT 


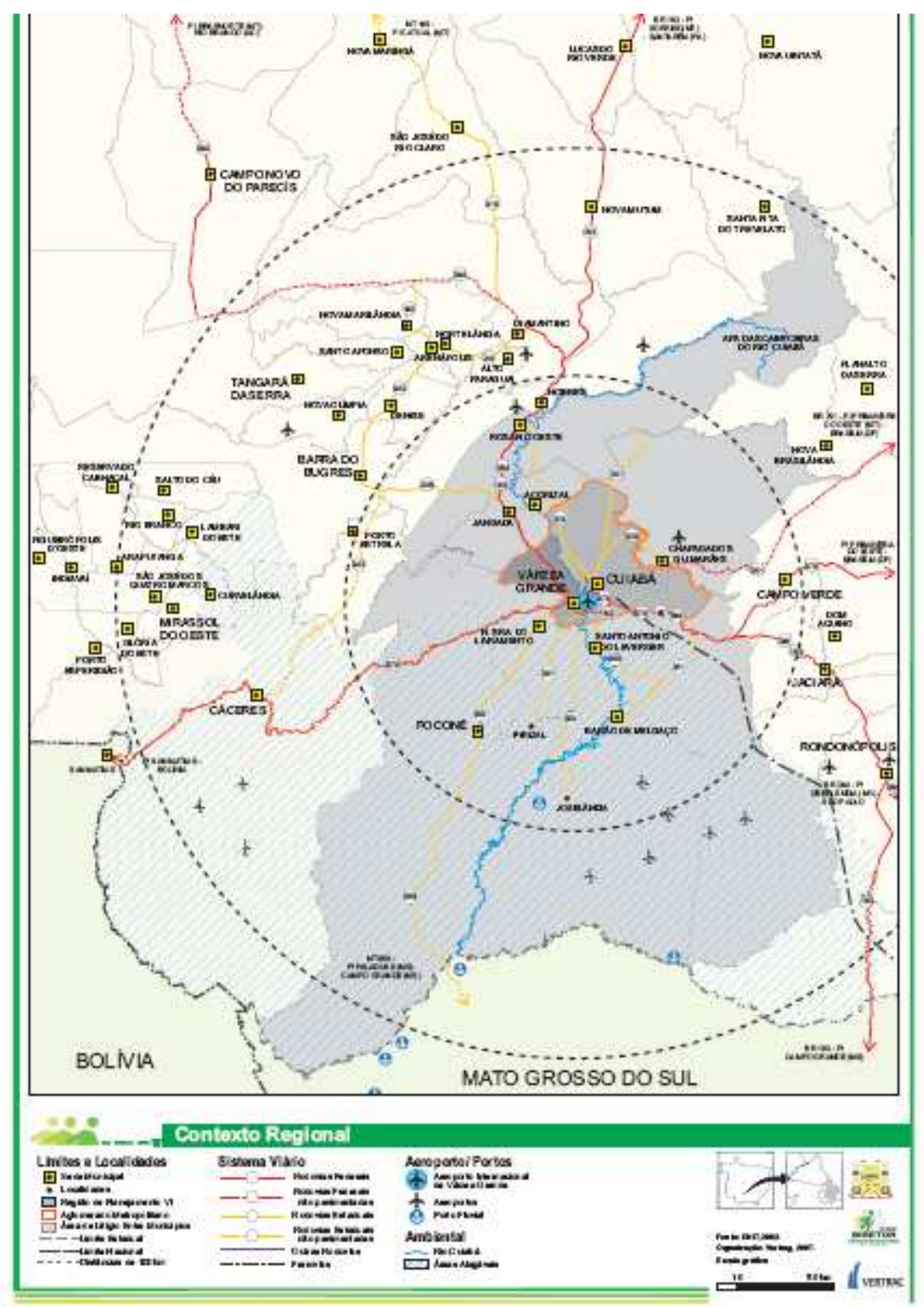

Figura 11 - Contexto Regional Fonte - VERTRAG 


\section{2- $\quad$ AS CÂMARAS SETORIAIS}

Quanto aos trabalhos das Câmaras Setoriais, segundo CHILETTO (2005), verificou-se o seguinte:

\section{A) Indústria, Comércio e Mineração}

Discutiu-se a questão da ampliação do Distrito Industrial, e apesar de sua atuação no princípio (ano de 2002), não veio repetindo o mesmo entusiasmo anterior ao longo do tempo.

\section{b) Meio ambiente}

Por concentrar grandes problemas, e pelo caráter muitas vezes interdisciplinar das questões envolvidas, esta câmara teve dificuldades de se reunir individualmente. Desta forma freqüentou as discussões em várias outras Câmaras como a de Serviços Públicos onde se debateu a proposta de instalação de aterro industrial no AGLURB, e a questão dos postos para depósito de resíduos sólidos da construção civil.

\section{c) Trânsito e Transporte}

Foi, sem dúvidas, a Câmara mais atuante, pois veio cumprido o calendário e as constantes reuniões (quinzenais) necessárias para a apreciação de tantos assuntos relevantes.

Os trabalhos resultaram na contratação do Plano Integrado de Transporte Coletivo do AGLURB, e o produto já foi apresentado às prefeituras envolvidas e ao Estado.

\section{d) Serviços Públicos}

A motivação dos técnicos levou à elaboração de Projeto para o Sistema de verificação de Óbitos (Resolução n¹1/2003) em comum com a Câmara Setorial de Saúde, e também estudos para a proposição de um Sistema Integrado de Limpeza Urbana, um estudo sobre a proposta de um Aterro Industrial no AGLURB e a questão da destinação dos resíduos sólidos da construção civil, cujo projeto que já vem sendo implantado na capital deverá ser viabilizado para todo o aglomerado. 


\section{e) Saúde}

A Câmara desenvolveu um Sistema de Inspeção Sanitária para o AGLURB junto da Câmara Setorial de Agricultura e Abastecimento e conforme a Resolução $\mathrm{n}^{\circ}$ 12/2003, desenvolve em conjunto com a Câmara de Serviços Públicos um Sistema de Verificação de Óbitos no Aglomerado.

\section{f) Educação e Cultura}

Esta Câmara não apresentou projetos significativos, e a falta de quorum nas reuniões demonstrou a falta de interesse de se discutir o assunto em conjunto.

\section{g) Agricultura e Abastecimento}

Foram elaboradas duas propostas que foram aprovadas na reunião do Conselho Deliberativo, a $n^{\circ} 11 / 2003$ e a $n^{\circ} 12 / 2003$, que tratam da criação de grupos de trabalho para a elaboração de projeto do Sistema Integrado de Inspeção Sanitária do Aglomerado Urbano (GT-SIS/AGLURB), envolvendo a Câmara Setorial de Agricultura e Abastecimento e a Câmara Setorial de Saúde, e para o projeto de uma Central de Abastecimento para o aglomerado Urbano (GT-CA/AGLURB) envolvendo apenas esta Câmara Setorial.

Em 2006 foi apresentado um esboço de um projeto, onde uma Central de Abastecimento localizada em Várzea Grande (entre o Trevo do Lagarto e a Ponte Mário Andreaza) envolvendo inclusive os pequenos produtores das cidades vizinhas. Atualmente uma estrutura para abrigá-lo já está sendo construída”.

\section{h) Habitação e Urbanismo}

Esta Câmara aprovou no Conselho Deliberativo a Resolução 09/2003, onde foi criado o Grupo de Trabalho para a elaboração do Projeto do Sistema Cartográfico com Informações Georreferenciadas do Aglomerado Urbano, que subsidiaria a implantação do Sistema de Informações Urbanas do Aglomerado. Este grupo ficou vinculado à Câmara Setorial de Segurança Pública. A subcomissão para desenvolver os estudos se reuniu extraordinariamente em várias ocasiões, o que resultou em uma proposta de convênio a ser apreciada e firmada pela Secretaria de Segurança Pública do Estado (pois partiria da utilização do banco de dados do Centro Integrado de Ocorrências de Segurança Pública - CIOSP) e os municípios do AGLURB”. 
Além da batalha para viabilizar este banco de dados, outras intervenções foram fonte de discussões, como por exemplo, o prolongamento e estruturação do Distrito Industrial de Cuiabá ao longo da BR 163 adentrando Várzea Grande; A reforma e estruturação do terminal de embarque e desembarque do Aeroporto Marechal Rondon, adaptando-o para receber efetivamente vôos internacionais; a nova perimetral que contornará Cuiabá (hoje já está com vários trechos prontos), e várias discussões sobre o sistema viário do Aglomerado.

Outra questão de suma importância é a elaboração do Plano Diretor para o Aglomerado Urbano, cuja licitação para contratação de assessoria foi viabilizada, e buscará uma forma inovadora de se planejar de forma conjunta.

Quanto às questões referentes á habitação, lamentavelmente pouco se evoluiu, visto que se trata de uma questão relevante para o Aglomerado, pois se verifica carência de habitações além dos graves problemas fundiários.

\section{i) Turismo}

Mesmo com imensa potencialidade turística nos municípios da localidade, esta Câmara Setorial não se reuniu com a frequiência pretendida, e nem apresentou propostas para o fomento do turismo no Aglomerado, o que é lamentável, pois representa um setor que poderia viabilizar empregos e renda para as cidades.

\section{j) Segurança Pública}

Esta Câmara Setorial possuiu um dos mais altos índices de participação, o que demonstra a motivação dos técnicos, que tem trabalhado na viabilização do Sistema de Informações do Aglomerado (Resolução n09/2003) juntamente com a Câmara Setorial de Habitação e Urbanismo, e ainda se ocupam de duas propostas: Religare e Pare Agora, visando à melhoria da segurança no Aglomerado.

CHILETTO (2005) verificou em seus estudos que "entre 2002 e 2004 a frequiência às reuniões das Câmaras Setoriais foram abaixo do esperado (60\%), e não se verificou melhora de 2004 até os dias atuais (conforme entrevista). As reuniões são insuficientes para deslanchar os projetos, o que acaba demandando longo tempo para que se viabilizem e se tornem benefícios concretos para a população. Os técnicos do Estado foram os que mais compareceram às reuniões, seguidos dos de Várzea Grande. O fato de os técnicos estarem envolvidos com os afazeres de suas Secretarias, muitas 
vezes causa empecilhos para que os trabalhos caminhem com maior celeridade no AGLURB”.

Contudo, observou-se que o Aglomerado Urbano ampliou os debates sobre os problemas comuns das cidades de Cuiabá e Várzea Grande, e tem se buscado soluções comuns, o diálogo tem sido uma constante e mesmo com a falta de uma política nacional adequada às regiões metropolitanas e aos aglomerados urbanos, a Lei dos Consórcios representa um passo a mais para ações integradas entre os municípios. A conversação (diálogo) tem sido o principal avanço e certamente tem rendido projetos e ações para o Aglomerado, mas infelizmente são poucos os projetos que se viabilizam, especialmente nas áreas mais problemáticas como o sistema viário, transporte, habitação e saneamento ambiental.

Após várias discussões e conflitos, a Câmara dos Deputados do Estado aprovou o projeto de lei para a criação da Região Metropolitana do Vale do Rio Cuiabá, compreendendo Cuiabá, Várzea Grande, Santo Antônio de Leverger e Nossa Senhora do Livramento.

\section{3- A REGIÃO METROPOLITANA DO VALE DO RIO CUIABÁ}

A Lei Complementar no 359 de 27 de maio de 2009 dispôs sobre a criação da Região Metropolitana do Vale do Rio Cuiabá.

A Lei define (art. $1^{\circ}$, inc. I) o que considera região metropolitana, segundo o art. 302 da Constituição do Estado.

“...o agrupamento de municípios limítrofes, em processo de conurbação, integrantes do mesmo complexo geoeconômico e social, que exijam o planejamento integrado, a organização e execução compartilhada das funções públicas de interesse comum".

Definiu também (art. $1^{\circ}$, inc. II) como Entorno Metropolitano, municípios vizinhos à Região Metropolitana do Rio Cuiabá e que estão também envolvidos no processo de metropolização.

Ainda que o município não esteja tão próximo da capital, ou dos municípios em processo de conurbação, mas que sofram influências desta região, dependência de prestação de serviços, especialmente os públicos, que tenham condições de desenvolvimento integrado e com complementação das funções (art. $3^{\circ}$, inc. I, II e III), deverão participar do processo de planejamento da Região Metropolitana. 
Compõem a Região metropolitana do Vale do Rio Cuiabá, além da capital Cuiabá, os municípios de Várzea Grande, Nossa Senhora do Livramento e Santo Antônio de Leverger (art. $2^{\circ}$ ).

Criou-se ainda o Entorno Metropolitano constituído dos municípios de Acorizau, Barão de Melgaço, Chapada dos Guimarães, Jangada, Nobres, Nova Brasilândia, Planalto da Serra, Poconé e Rosário Oeste.

$\mathrm{O}$ art. $5^{\circ}$ da Lei cosidera Funções Públicas de Interesse comum:

"...as atividades ou os serviços de natureza local, cuja realização seja de interesse de mais de um dos municípios da aglomeração urbana; ou cuja realização por parte de um município, isoladamente, seja inviável, não atinja os objetivos propostos ou cause impacto nos outros municípios integrantes da Região Metropolitana”.

O parágrafo único do artigo supracitado define as funções públicas de interesse comum como sendo:

I- "desenvolvimento econômico e social;

II- planejamento do uso e da ocupação do solo;

III- acessibilidade e mobilidade;

IV- saneamento ambiental;

$\mathrm{V}$ - preservação e conservação do meio ambiente;

VI- desenvolvimento urbano e políticas públicas setoriais (habitação, saúde, educação, segurança, turismo, esporte e lazer), entre outras".

Segundo a Lei, as funções públicas, cujo interesse seja de mais que um município integrante, serão executadas em regime de colaboração entre Estado e Municípios que compõe a Região Metropolitana, e serão baseados em plano diretor participativo da Região Metropolitana que está em elaboração e deverá ser aprovado por instância deliberativa a ser criada na forma da lei.

O Estado irá executar os planos e programas através de órgão do Poder Público a ser criado.

As primeiras propostas para a criação desta Região Metropolitana continham mais municípios (Jangada, Acorizau, Chapada dos Guimarães entre outros dependendo da proposta e dos critérios adotados), mas a solução encontrada vem de encontro ao bom senso, tendo em vista que o primeiro passo foi a determinação na Constituição Estadual do que seria uma Região Metropolitana e seu entorno. Assim se coloca de forma clara os parâmetros que nortearam a sua criação. 


\section{CAPÍTULO 4 - OS PLANOS DIRETORES DE CUIABÁ E VÁRZEA GRANDE}

\section{1- OS PLANOS DIRETORES APÓS A CONSTITUIÇÃO DE 1988}

Por força constitucional, no início da década de 1990, Cuiabá e Várzea Grande elaboraram seus planos diretores. Cuiabá já tinha plano e uma vasta legislação urbanística, Várzea Grande quase nada além de regras para as obras. Na época Cuiabá contava com 383.140 habitantes e Várzea Grande com 151.314 habitantes.

O plano diretor de Cuiabá, a cargo do IPDU foi iniciado em 1990, tendo sido a estrutura e o conteúdo estabelecidos pela lei orgânica municipal, sendo que este foi concebido para ser implantado em etapas que demoraram mais do que o previsto devido a alguns debates com a sociedade e a alguns conflitos, somente em 1992 pôde ser concluído.

Uma minuciosa pesquisa sobre a cidade foi realizada com o apoio da Universidade Federal de Mato Grosso (UFMT). A equipe técnica da prefeitura foi dividida por assuntos, onde cada órgão tinha um responsável geral e uma equipe para auxiliá-lo nas atribuições segundo sua área de atuação. Assim o Plano Diretor foi construído com pouca ajuda da sociedade (ao menos nesta primeira fase), e devido às classes mais modestas não terem participado das discussões, não pôde ser dito que foi participativo. A participação popular, contudo, foi ampliada nas discussões sobre os planos setoriais, e em especial o abairramento.

O plano diretor de Cuiabá, Lei Complementar n003/1992 não adotou um zoneamento rígido, mas o conceito de compatibilidade de usos, em função da infraestrutura urbana disponível e dos usos predominantes já existentes na localidade. Toda a legislação urbana foi revista e adaptada conforme o plano diretor, estando até o momento ainda vigorando. O plano diretor de Cuiabá foi, de certa forma conhecido por todos e aplicado, norteando a legislação e as ações no município.

O plano diretor de Várzea Grande ficou a cargo da Secretaria Municipal de Viação Obras e Urbanismo. Para tanto foram contratados técnicos (alguns vindos da UFMT) que elaboraram a minuta da Lei do Plano Diretor, do Código de Obras e Lei de Uso e Ocupação do Solo e o Zoneamento. Estas leis eram para ser aprovadas em um único documento, porém a Câmara dos Vereadores aprovou em duas Leis separadas, o Plano Diretor e as demais. 
A legislação de Uso Ocupação do Solo e o Zoneamento foram conhecidos, mas não foram colocadas em prática por questões técnicas, políticas e circunstanciais (podemos citar como exemplos o fato da lei ser incompatível com a cidade real, a forte influência política sobressaindo as questões técnicas e legais e o desaparecimento dos mapas que definiam as Zonas, o Perímetro Urbano e a Hierarquização Viária).

Assim como os mapas que constituíam os anexos do Plano Diretor de Várzea Grande desapareceram, o Plano Diretor, Lei 1.266/1992 também desapareceu. Nenhum técnico da prefeitura, nem mesmo os da secretaria de Obras e Urbanismo ou da Procuradoria Jurídica sabiam dele. A informação prestada era que o Plano Diretor de Várzea Grande não havia sido promulgado pelo prefeito e então não surtia efeitos legais. Porém, não era verdade, o Plano Diretor de Várzea Grande existia e estava bem escondido, só foi descoberto, no fundo das prateleiras da Procuradoria municipal com a troca de gestão em 2004, quando o município, por força legal, teria que elaborar ou rever seu plano diretor.

\section{2- O PROCESSO DE ELABORAÇÃO DOS ATUAis PlanOS DIRETORES}

\subsection{1- CONSTRUÇÃO DO PLANO DIRETOR DE VÁRZEA GRANDE}

As primeiras ações para a revisão do Plano Diretor de Várzea Grande se desenvolveram na gestão 2001-2004, com a captação de recursos do Programa Habitar Brasil - Banco Interamericano de Desenvolvimento (HBB) para revisão de planos diretores municipais. Para que o prazo legal de ajuste do plano diretor ao Estatuto da Cidade fosse cumprido, foi produzido e aprovado junto à Caixa Econômica Federal um Termo de Referência que subsidiou o processo licitatório para a contratação de consultoria para a revisão do Plano Diretor de Várzea Grande e sua legislação urbanística. Nos meses de maio e junho de 2005, a Secretaria de Planejamento de Várzea Grande (SEPLAN) em conjunto com o Instituto de Pesquisa e desenvolvimento Urbano de Cuiabá (IPDU) definiram uma agenda de reuniões com a finalidade de planejar a campanha e dar início aos trabalhos para revisão dos respectivos planos diretores.

A estratégia acordada pelo município foi segundo a VERTRAG: 
“a) Definição do âmbito e alcance da revisão / elaboração dos Planos Diretores de Várzea Grande e Cuiabá, identificando áreas e problemas comuns no contexto do Aglomerado Urbano;

b) Constituição de equipe composta por representantes das diversas Secretarias Municipais, de ambos os municípios, para participar do processo;

c) Definição dos espaços de participação dos representantes dos demais órgãos públicos Federais e Estaduais, cuja atuação poderia ser considerada afim ao processo de gestão do Aglomerado Urbano;

d) Definição dos espaços de participação dos representantes das entidades da sociedade civil organizada, incluindo movimentos comunitários, sindicais, entidades de pesquisa, de classe e organizações não governamentais (ONGs).

e) Discussão dos eixos estratégicos, grupos e categorias beneficiárias das ações públicas, com o objetivo de nortear as atividades dos diversos participantes;

f) Definição de cronograma de atuação para cada um destes grupos, e os prazos dos poderes Executivos e Legislativos, para viabilizar a conclusão da revisão / elaboração de acordo com a legislação". (Plano diretor participativo de várzea grande: 2007-2017, volume 1)

A partir de janeiro de 2006, a consultoria passou a integrar o processo de construção do Plano Diretor de Várzea Grande, imprimindo um ritmo mais acelerado ao processo no município.

Consoante proposta apresentada pela consultoria vencedora (VERTRAG), o projeto de elaboração foi dividido da seguinte forma:

Fase 1: Plano de Trabalho e Metodologia;

Fase 2: Leitura Comunitária da Cidade e do Território;

Fase 3: Avaliação Temática Integrada

Fase 4: Síntese das leituras Técnicas e Comunitárias;

Fase 5: Proposições e Eixos Estratégicos;

Fase 6: Legislação Básica.

A Fase 1, Plano de Trabalho e Metodologia, (desenvolvida em maio de 2006) teve como objetivo a apresentação e articulação entre os diversos atores que participariam da elaboração do Plano Diretor, sendo eles os técnicos da prefeitura, da Caixa Econômica Federal, os técnicos da consultoria, do Aglomerado Urbano, e da sociedade civil organizada representada por uma comissão de acompanhamento.

A Fase 2, Leitura Comunitária da Cidade e do Território, (desenvolvida em maio de 2006 teve como objetivos: 
- Levantar as demandas, organizá-las e fazer o seu mapeamento no território, levando em conta diferentes escalas como a local, do bairro, da região, tanto para as áreas urbanas quanto para as rurais.

- Identificar os grupos de interesse e os conflitos entre os diferentes usos e formas de ocupação do solo.

A Fase 3, Leitura Técnica Integrada, (realizada de outubro de 2006 até fevereiro de 2007), teve como objetivo o conhecimento da realidade municipal abordando as questões regionais, ambientais, socioeconômicos, socioespacial, de infraestrutura e serviços públicos, institucionais e históricos.

Para isso, foram previstas as seguintes atividades complementares:

- Coleta e análise de dados, seguido de mapeamento das informações coletadas.

- Apresentação do diagnóstico e discussão, em reunião com os técnicos, a consultoria e a Comissão de Acompanhamento ${ }^{7}$.

- Avaliação do documento preliminar pelo Núcleo Gestor Municipal e pela Caixa Econômica Federal.

- Audiência Pública para apresentação da leitura da realidade municipal.

- Finalização da Avaliação Temática Integrada reunindo a leitura técnica e comunitária.

Na Fase 4, Síntese da Leitura Técnica e Comunitária, (realizada no mês de fevereiro de 2007) foram confrontados os dados levantados e analisados na leitura técnica e na leitura comunitária identificando os principais temas abordados nas fases anteriores. Desta forma obteve-se, como produto, o diagnóstico da realidade municipal, apresentada em forma de texto, matrizes e mapas em audiência pública, subsidiaram as propostas para o Plano Diretor.

A Fase 5, correspondente à Proposições e Eixos Estratégicos, (realizada entre março e junho de 2007), foram definidas as diretrizes e eixos estratégicos para o desenvolvimento municipal a partir da síntese das leituras técnicas e comunitárias, considerando os aspectos:

- Ambientais;

- Socioeconômicos;

- Socioespaciais;

\footnotetext{
${ }^{7}$ Composta pela sociedade organizada.
} 
- Infraestrutura;

- Serviços públicos e;

- Institucional.

Foram estabelecidas as estratégias de intervenção considerando a realização em curto, médio e longo prazo. Antes do fechamento foram realizadas dez reuniões com a comunidade para apresentação e discussão final. Assim esta fase se dividiu em: apresentação das propostas; discussão das diretrizes em reuniões; avaliação das diretrizes pelo Núcleo Gestor Municipal e Caixa Econômica Federal e audiência pública para apresentação das propostas.

A Fase 6, Legislação Básica, (que aconteceu entre maio e junho de 2007), foi dedicada à elaboração da minuta de Lei do Plano Diretor, que foi mais uma vez discutido e aprovado em audiência pública, antes de ser encaminhado para a Câmara de Vereadores.

O processo de elaboração do Plano Diretor de Várzea Grande foi, como se observou, bastante participativo e as reuniões, assim como as três audiências públicas, contaram com a participação de técnicos da Prefeitura de Cuiabá, do Governo do Estado (em especial do AGLURB), e da Caixa Econômica Federal. O Ministério Público Estadual acompanhou a elaboração dos planos diretores tanto de Cuiabá como de Várzea Grande, o que garantiu que os princípios do Estatuto da Cidade, em especial no que tange a participação da comunidade, fossem garantidos.

\section{a) Leitura Comunitária}

A fase de Leitura Comunitária foi a mais trabalhosa e desafiadora, tendo em vista o tamanho do município, a inexperiência da equipe gestora da prefeitura e a falta de hábito da população em estar discutindo as questões urbanas. Contudo, contou-se com a experiência da consultoria e com a capacitação (oferecida pelo Núcleo de Acompanhamento dos Planos Diretores do Estado de Mato Grosso, de iniciativa da SEPLAN do Estado) realizada por alguns técnicos da prefeitura.

Esta fase teve como objetivo o conhecimento das potencialidades e problemas do município a partir do olhar da população sobre o território, nas áreas de meio ambiente, infra-estrutura, serviços, aspectos institucionais, socioeconômicos, socioespaciais, históricos. Buscou-se identificar qual a cidade desejada pela sua população. Quanto à participação social (que orientou o plano diretor) conforme a VERTRAG, 2007: 
"considerou-se participação como o exercício do direito que todo cidadão tem de manifestar-se tanto no planejamento e discussão, quanto na decisão de questões que direta e indiretamente afetam seu cotidiano".

A participação comunitária, segundo mesmo documento da consultoria, teve como elementos fundamentais:

“(a) A instauração do Núcleo Gestor Municipal e da Comissão de Acompanhamento, de tal forma que tanto o poder público local quanto os segmentos sociais atuantes no município, estivessem comprometidos com a função de preparar, conduzir, apoiar e monitorar, junto com a consultoria, a realização das atividades da fase;

b) A mobilização social, cuja estratégia para efetivação procurou reunir os recursos existentes (humanos e financeiros), visando à identificação dos agentes sociais presentes no município, suas territorialidades e formas de organização, construindo um processo compartilhado e com participação de todos;

c) A capacitação, que consistiu na transferência da metodologia para a realização da fase aos multiplicadores, integrantes do Núcleo Gestor Municipal e da Comissão de Acompanhamento. Dentre os elementos desse instrumental destaca-se: a investigação-ação, a observação participante e militante, a prestação de informações para análise da realidade, técnicas de grupo, estimulação ao exercício da liderança e da prática de planejamento participativo, prestação de assessoria em situações especiais, e capacitação para a conquista de espaços crescentes de participação;

d) "Reuniões nas escalas da comunidade e do bairro, para as áreas urbanas e rurais, instância onde, através da aplicação da metodologia de participação adotada, realizou-se efetivamente a leitura da realidade vivida pela população".

Orientaram o processo, a Lei 10.257/2001 (Estatuto da Cidade) e a Resolução 25 do CONCIDADE, cujos fundamentos, segundo documento denominado Fase 1: Plano de trabalho e Metodologia, são:

“a) Representatividade - processo aberto a todos os segmentos do município, organizados ou não;

b) Territorialidade - análise a partir dos territórios geograficamente definidos em funções das suas especificidades;

c) Caráter pedagógico - fazer aprendendo e aprender fazendo, como forma de fazer avançar o conhecimento sobre o seu território, o município e a região;

d) Interatividade - troca de saberes entre os agentes envolvidos no processo;

e) Transparência - disponibilidade das informações levantadas e produzidas ao longo de todas as fases do processo;

f) Flexibilidade metodológica - abordagem dinâmica da metodologia, ajustando-a sempre que necessário". 
O processo da leitura comunitária iniciou com reuniões entre o Núcleo Gestor e a consultoria nas quais foi estabelecida a divisão territorial para a realização das reuniões com a comunidade, de forma que todas as comunidades fossem ouvidas, tanto no âmbito urbano como no rural; o cronograma das reuniões; a estratégia de mobilização da população e a metodologia a ser aplicada nos encontros.

\section{b) A divisão territorial}

Quanto à divisão territorial, a falta de abairramento no município fez com que fossem necessários esforços do Núcleo Gestor para dividir o território municipal levando em consideração as características físicas, proximidade e afinidades entre as localidades. Desta forma, a porção urbana foi dividida em quatro grandes setores: Norte, Centro-Sul, Leste e Oeste.

Estas quatro regiões foram subdivididas em doze polos, considerando a extensão territorial e a densidade populacional e a divisão adotada pelo IBGE, quando possível. Foi definido que o ponto de apoio onde se dariam as reuniões seriam as escolas públicas, por serem locais conhecidos da população, ter credibilidade e fazerem parte do cotidiano da população.

Além destes doze polos, verificou-se a necessidade de reunir-se com mais dois grupos, os representantes do segmento produtivo, pela responsabilidade quanto ao desenvolvimento econômico local, e os gestores públicos, pela responsabilidade na implementação das políticas públicas e do Plano Diretor.

A proposta de regionalização, data e locais, foram apresentadas às lideranças comunitárias em reunião, onde foram feitos ajustes segundo sugestões e acordos fechados na ocasião.

\section{c) Mobilização}

A mobilização seria um ponto decisivo para que se pudesse envolver o maior número possível de pessoas e desta forma atender ao princípio da participação da população na elaboração do Plano Diretor de Várzea Grande, então se optou por duas frentes de trabalho, a Escolar e a Comunitária.

A Escolar foi composta pelos dirigentes das escolas, orientadores pedagógicos, professores, alunos e representantes dos conselhos escolares.

A Comunitária foi composta pela população residente em cada bairro e por seus representantes (associações, "presidentes de bairro" e outras lideranças). 
Através da Secretaria de Promoção Social e da União Várzea-grandense de Associações de Moradores de Bairro (UNIVAB), foram relacionadas as principais lideranças das localidades, e o convite para as reuniões foram encaminhados pessoalmente para cada um. Por outro lado, foi utilizado carro de som nos bairros anunciando cada evento ligado à elaboração do plano diretor, afixação de faixas, anúncios nos meios de comunicação, especialmente na rádio comunitária que funciona no terminal Central André Maggi e foram ainda distribuídos panfletos e cartazes nos locais de maior circulação de pessoas.

Para as audiências públicas, foram providenciadas camisetas com a logomarca da campanha para as lideranças comunitárias a fim de reconhecê-las como agentes de referência para a mobilização social. Por fim, foi disponibilizado transporte público gratuito em todo o território municipal para que a população pudesse ter acesso às audiências públicas.

\section{d) A Capacitação}

Para que todos os agentes envolvidos pudessem se preparar e entender o que estava acontecendo, sabendo o que é um Plano Diretor, para que serve, e qual seu papel no destino da cidade, foram programadas capacitações para os servidores municipais e políticos (incluindo secretários, vereadores e assessores); as lideranças comunitárias; os professores e os agentes ligados às escolas (diretores, supervisores entre outros).

Nestas capacitações foram tratados os seguintes assuntos;

- O processo de urbanização ocorrido no Brasil e no Estado do Mato Grosso, esclarecendo sobre a origem dos problemas socioespaciais e ambientais decorrentes desse processo;

- Os artigos 182 e 183 na Constituição Federal de 1988, e sua importância para as cidades

- O Estatuto da Cidade em 2001, e seus instrumentos, ressaltando a importância que a sociedade organizada teve no processo de construção e aprovação desta lei;

- O que é plano diretor participativo, qual sua importância para a cidade e as etapas de elaboração do mesmo;

- O que é participação, e por que participar, e como estar participando do processo de elaboração do Plano Diretor. 
Alguns segmentos que estariam envolvidos diretamente com a população nas reuniões dos bairros foram esclarecidos sobre os aspectos referentes à metodologia que seria aplicada.

\section{e) Metodologia para as Reuniões com a População}

No entendimento tanto da consultoria como do Núcleo Gestor, a população costuma analisar sua realidade a partir da localidade onde mora, estabelece vínculos com seu habitar, faz a leitura de onde mora a partir de seu cotidiano, da vivência das situações particulares de cada um e de seus costumes.

"O cidadão normalmente sente os efeitos, mas tem dificuldade de avaliar e detectar as causas determinantes que conduzem às situações identificadas seja elas boas ou más" (Fase 1: Plano de trabalho e Metodologia).

A capacitação para a população teria que acontecer nos encontros, deveria ser rápida, direta e em linguagem bem acessível. Desta forma, as reuniões foram abertas realçando a importância do processo de elaboração do Plano Diretor, e de forma sintética, a origem dos problemas no Brasil e quais os instrumentos que poderiam ser utilizados. Apresentou-se o vídeo do Ministério das Cidades por apresentar tais questões através de uma linguagem de fácil compreensão.

A metodologia escolhida para estes encontros foi a denominada "Oficina do Futuro". Esta metodologia, "Oficina do Futuro," assim foi explicada pela consultoria:

"Tal metodologia estrutura-se a partir da prática da pesquisaação, que considera as dimensões do sonho coletivo, da estruturação da realidade, e do contexto histórico, e tem o objetivo de garantir que os representantes das comunidades e das instituições presentes envolvam-se e sintam-se co-responsáveis do processo de construção participativa do PDM. O objetivo da oficina seria atingido, na medida em que a população reconhece que as suas necessidades, prioridades e expectativas em relação ao município encontram-se inseridas nas leituras e propostas do Plano Diretor". (FASE um: PLANO DE TRABALHO E METODOLOGIA, VERTRAG, 2007, pág.. 56).

Os exercícios desenvolvidos pela "Oficina do Futuro" permitiram que existisse identificação das responsabilidades de cada um no processo e envolvimento com o grupo, fazendo com que cada um se sentisse pertencente a ele. Para os trabalhos, os participantes foram divididos em grupos de aproximadamente cinco ou seis pessoas. As atividades foram divididas em três fases:

a) A árvore dos sonhos; 
b) As pedras no caminho;

c) As flores no caminho.

A árvore dos sonhos correspondeu à negociação do sonho coletivo, cujo produto foi a árvore dos sonhos onde cada grupo expôs seus sonhos que deveriam responder a duas perguntas: como é o bairro dos nossos sonhos? E, como é a Várzea Grande dos nossos sonhos?

Após debate, cada grupo escreveu seus sonhos em um pedaço de papel colorido (verde claro para a escala do bairro e verde escuro para a escala da cidade) e os deixavam colados na árvore dos sonhos, de forma que se estabelecesse um debate sobre os sonhos apresentados, alterando-os ou não.

Foi então solicitado aos participantes que promovessem a hierarquização dos sonhos, que seriam transformados em propostas de cada polo.

Para o Caminho das Pedras, foram identificados pelos grupos problemas, que depois de escrito em papel (cor marrom), e fixados no "caminho", representaram as dificuldades em transformar os sonhos em realidade. Após debate com o grupo, foram aprovados ou não.

$\mathrm{Na}$ Fase das Flores do Caminho, os grupos identificaram as potencialidades do bairro e da cidade que poderiam viabilizar a realização dos sonhos. Após outro debate, foram eleitas as questões que o grupo considerou importantes.

Desta forma, a partir da reflexão individual, se estabeleceu um relacionamento com o grupo e assim construídas as propostas. Segundo documento da consultoria:

"A sistematização das respostas segundo as fases sonho, pedras e flores, possibilitou a organização das idéias, e correlação das mesmas segundo diferentes temas. A organização das fases em painéis possibilitou que durante toda a atividade não se perdesse a visão do todo. O compartilhamento das idéias pelos grupos facilitou a re-elaboração e a retomada de questões discutidas por todos, de tal forma que os participantes, ao final, produzissem uma síntese da discussão". (FASE 1: PLANO DE TRABALHO E METODOLOGIA, PÁG. 57).

Em algumas localidades, como na Zona Rural, no polo Don Bosco, Jardim de Alá, Icaraí e Capão Grande, a metodologia teve que sofrer ajuste para se adaptar à falta de espaço para comportar todas as pessoas ou, como no caso do pólo Don Bosco, por serem poucos os participantes, foi transformado em discussão sobre como integrar a região com as demais áreas urbanas da cidade. 
Cabe dizer que em todas as reuniões foi fixado mapa de Várzea Grande, onde os participantes podiam identificar seu bairro no contexto da cidade.

Ao todo foram dezenove reuniões com a população, incluindo a zona rural. Destas reuniões se colheu a imagem da população sobre Várzea Grande e sobre seu bairro, os problemas, as potencialidades os conflitos e seus sonhos para a cidade. Todas estas questões foram sintetizadas em matrizes divididas por pólos e regiões, e utilizadas para a análise da realidade municipal e para embasar o documento denominado "Síntese das Leituras Técnica e Comunitária”, que embasaram as diretrizes para o desenvolvimento municipal, presentes no Plano Diretor.

\subsection{2- CONSTRUÇÃO DO PLANO DIRETOR DE CUIABÁ}

A equipe técnica de Cuiabá encontrava-se em melhores condições para elaborar o plano diretor, tendo em vista que muitos dos técnicos do IPDU e de outros órgãos da prefeitura já possuíam experiência na construção de plano diretor, tendo participado da elaboração do atual plano em vigência, e ao conduzirem as reuniões comunitárias para elaboração do abairramento da cidade, conheciam como lidar com a questão participativa. Desta forma Cuiabá não contratou consultoria e assumiu sozinha a tarefa. Por conta disto, o processo de construção não foi tão documentado como o de Várzea Grande, de modo que foi resgatado apenas através de entrevistas com os técnicos.

O IPDU assumiu os trabalhos, apoiado por técnicos das diversas secretarias e demais órgãos da prefeitura, e aconteceu em junho de 2006 o primeiro seminário, com duração de dois dias, onde estiveram presentes os técnicos da prefeitura, do Estado, do município de Várzea Grande e outras instituições como representantes da Caixa Econômica Federal. Na reunião, foi apresentado o Estatuto da Cidade e o que é e qual a importância do plano diretor para o município. Também foram apresentadas as diversas ações realizadas, em execução e planejadas por cada secretaria ou órgão, e as dificuldades de cada um. Este seminário serviu para que todos tivessem as mesmas informações sobre a prefeitura e o município, antes das próximas fases.

Um mês depois foi realizado um novo seminário, com duração de dois dias e com uma dinâmica diferente. Foram convidados os técnicos da prefeitura de Cuiabá e de Várzea Grande, do governo do Estado, da Caixa Econômica Federal, do CREA e outras instituições ONGs, lideranças comunitárias e a população em geral (o convite foi 
divulgado através de jornais e outros meios de comunicação). Nesta ocasião os trabalhos foram divididos em sete grandes eixos, sendo eles:

- Meio ambiente, incluindo saneamento e limpeza urbana;

- Mobilidade urbana, incluindo transporte, trânsito e sistema viário;

- Desenvolvimento econômico;

- Desenvolvimento social;

- Habitação e regularização fundiária;

- Grandes obras estratégicas;

- Modernização institucional.

Foram apresentadas as dificuldades, as ações que estavam sendo realizadas e as que deveriam acontecer para poder melhorar a cidade para cada um destes aspectos (os participantes foram conduzidos para salas onde se discutiria cada assunto, segundo seu interesse). Os trabalhos foram concluídos com as propostas apresentadas e aprovadas em uma grande assembléia com a participação de todos.

Neste seminário aconteceu a leitura técnica conjuntamente com a comunitária, diferente dos trabalhos na cidade de Várzea Grande que dividiu as duas fases.

Foram realizados mais sete seminários (com duração de uma noite cada) englobando as regionais: Norte, Sul, Leste e Oeste, o distrito da Guia, os demais distritos e o Centro Histórico. A dinâmica destes seminários constituiu em três fases:

- Análise da situação na região segundo cada tema;

- O que está sendo feito para a melhoria do problema;

- O que fazer em curto (até 2009), médio (até 2012), e longo (até 2022) prazo.

Desta forma estabeleceram-se as diretrizes do plano diretor, que depois de passar pelo Conselho Municipal de Desenvolvimento Urbano foi encaminhado à Câmara de Vereadores para aprovação.

\section{3- CARACTERÍSTICAS GERAIS DOS PLANOS DIRETORES}

O Plano Diretor Participativo de Várzea Grande, Lei 3112/2007, aprovado em 13 de dezembro de 2007, contou com consultoria da Vertrag Planejamento Ltda, contratada conforme o Contrato de Prestação de Serviços $n^{\circ}$ 025/2006, em conformidade com o Edital de Licitação na modalidade Toma de Preços no 19/2005, destinado à consultoria para revisão, elaboração, adequação e compatibilização da 
legislação urbanística do município, com as diretrizes, objetivos e instrumentos da Lei 10.257/2001, denominada Estatuto da Cidade.

O Plano diretor de Cuiabá foi elaborado pela equipe da prefeitura, que a partir da experiência adquirida por ocasião da elaboração do Plano Diretor anterior ao atual, e contando com um órgão de planejamento urbano estruturado - o IPDU - e equipe técnica com certa experiência, pode desenvolver os trabalhos necessários para a revisão do seu Plano Diretor.

Os atuais Planos Diretores de Cuiabá e Várzea Grande possuem linguagem técnica, e apesar de não contarem com glossário, são acessíveis à população. Tanto um como o outro poderiam ter desprendido esforços para propiciar uma legislação mais clara e simplificada, o que não aconteceu. Tanto um como o outro se valem de uma legislação de apoio e remetem inúmeras vezes para leis e planos que deverão ser elaborados não podendo, nem um nem outro, ser considerados auto-aplicáveis.

O Plano Diretor de Cuiabá se apóia nas seguintes Leis:

- Lei Complementar nº 004/97, que instituiu o Código Sanitário de Defesa do Meio Ambiente e Recursos Naturais;

- Código de Obras e Edificações

- Código de Posturas,

- Lei de Uso e Ocupação do Solo e Parcelamento do Solo Urbano;

- Lei 2.021, de 1982, que disciplina o parcelamento do solo urbano

- Lei 3.870 de 05 de julho de 1999 (hierarquização viária);

- Lei 103 de 05 de dezembro de 2003;

- Lei 044, de 23 de dezembro de 1997

- Lei Complementar $\mathrm{n}^{\circ}$ 108/03, que estabelece critérios técnicos para elaboração e implementação dos projetos de habitação popular de interesse social, entre outras Leis que fazem parte do arcabouço jurídico da prefeitura.

Estas Leis estão sendo revistas para se adequarem ao Plano Diretor vigente, e mesmo tendo sido estabelecido período de 360 dias após a promulgação do PDDE, só agora isto vem acontecendo tendo em vista a formação de uma equipe composta por técnicos de todas as áreas e setores da prefeitura que estão unindo esforços para rever a legislação. O plano diretor de Cuiabá depende de inúmeros planos setoriais, leis complementares e elaboração de políticas públicas para ter bons resultados, são eles: 
- Os instrumento para regularização de edificações em desacordo com a legislação desde que se enquadrem nas exigências (que não afetem as APPS, áreas verdes, praças, canteiros e passeios públicos);

- Plano municipal de recursos hídricos, observando o que dispõe o Plano Nacional e Estadual e os consórcios;

- Plano de controle ambiental;

- Plano de arborização do Município;

- Plano setorial de abastecimento

- Plano setorial de desenvolvimento industrial, comercial e de serviços;

- Plano de desenvolvimento rural integrado e de abastecimento;

- Plano de preservação do patrimônio cultural para o Município de Cuiabá, implementando o órgão responsável por sua gestão;

- Plano setorial de limpeza urbana;

- Plano especial para a revitalização econômica e a preservação do patrimônio artístico, cultural e arquitetônico do centro Histórico e seu entorno;

- Plano Setorial de Turismo;

- Plano Setorial de Acessibilidade e Mobilidade Urbana;

- Política e programas setoriais de forma articulada e integrada;

- Política e programas correspondentes nas áreas de recursos humanos e de valorização dos servidores municipais;

- Política e programa de regularização fundiária;

- Programas de remoção da população que esteja ocupando áreas de preservação ambiental, áreas verdes ou de risco, promovendo posteriormente a recuperação e isolamento das mesmas;

- Programa de recuperação do Patrimônio Imobiliário Municipal, ocupado de forma irregular ou cedido a terceiros que deixaram de cumprir a destinação prevista na concessão;

- Projeto de Lei de criação das zonas urbanas das sedes de todos os Distritos;

- Estudos técnicos para a criação dos Distritos do Aguço e de Nova Esperança/Piquizeiro, e readequadar os Distritos existentes; proposta de reabairramento e de divisão administrativas 
- Os condomínios residências, as atividades comerciais e industriais com potencial poluidor deverão providenciar sistemas de tratamentos próprios de efluentes e resíduos no prazo de cinco anos após a promulgação desta Lei;

- Elaborar projeto para novo sistema de captação e tratamento da água na área do Parque das Águas.

O Plano Diretor de Várzea Grande incorporou a legislação urbanística, dizendo que esta faz parte do plano diretor. As Leis (sem número):

- Lei do Perímetro Urbano;

- Lei de Zoneamento de Uso e Ocupação do Solo Urbano;

- Lei de Parcelamento do Solo Urbano;

- Lei do Sistema Viário;

- Lei do Código de Obras;

- Lei do Código de Posturas.

Apesar de já terem sido revisadas, ainda deverão ser elaborados:

- Programas de capacitação dos atuais servidores municipais (art. 18, inc. VI);

- Programa de capacitação envolvendo todos os níveis hierárquicos das empresas que atuam na cadeia produtiva do couro, móveis, cerâmica e alimentos (art. 19. inc. IV);

- Programa Municipal de Gestão da Cultura (art. 21, inc.III, alínea b);

- Programa de Gestão do Esporte e Lazer, que vise à inclusão social de crianças, adolescentes e jovens (art.21, inc. IV alínea e);

- Programa municipal de coleta e disposição final do resíduo sólido reciclável (art. 26, inc. XIII);

- Lei para concessão de isenções para atividades ou imóveis conforme o que estabelece o art. $37, \S 1^{\circ}$.

- Lei para dispor sobre parcelamento, a edificação e a utilização compulsórias do solo urbano (art. 42);

- Lei para estabelecer o valor da alíquota a ser aplicada a cada ano para o IPTU progressivo no tempo (art. $47, \S 1^{\circ}$ );

- Lei para delimitar as áreas em que concretamente incidirá o direito de preempção, definindo procedimentos e fixando prazos de vigência (art. 59);

- Lei para estabelecer os imóveis que poderão receber, e as condições a serem observadas para a outorga onerosa do direito de construir (art. 63); 
- Lei para especificar incentivos para a transferência de Potencial Construtivo. $\left(\right.$ art. 67, $\left.\S 3^{\circ}\right)$;

- Lei para estabelecer as regras a serem observadas para os Estudos de Impacto de Vizinhança (art. 81 e 82);

- Lei para instituir critérios gerais para a instituição de ZEIS (art. 90, § $1^{\circ}$ e art. 92);

- Lei para criação do conselho da cidade (art. 112)

- Lei para criação do Fundo Municipal de Desenvolvimento Urbano - FMDU $(\operatorname{art} 121)$.

O prazo estabelecido no Plano Diretor é de 180 dias contados a partir da sua promulgação, mas apenas a capacitação de alguns funcionários vem sendo realizada através do incentivo a cursos de pós-graduação e de graduação. O Município está levantando recursos junto ao Governo Federal para a elaboração do Plano de Habitação

Quanto à publicidade dos mesmos, o principal canal para que a população tenha acesso tanto aos planos diretores como à legislação urbanística é a internet, visto que se encontram disponíveis nos respectivos sites das prefeituras, contudo existe a impossibilidade de uma consulta mais detalhada pelo fato dos mapas estarem desconectados do Plano Diretor de Cuiabá e não terem sido colocados nos respectivos anexos no caso do Plano Diretor de Várzea Grande. Isto gera insegurança, pois no caso de Cuiabá não se sabe se o mapa consultado é o referente ao que se deseja e no caso de Várzea Grande, o problema se repete com um agravante, não está no site, e quando se busca a tal informação junto às prefeituras, Cuiabá remete ao site e Várzea Grande disponibiliza todo o material referente tanto à elaboração do Plano Diretor (como pesquisas, diagnósticos, matrizes entre outras informações) como a legislação urbanística. Porém os mapas vêm em anexos desconectados e fora do local apropriado, causando insegurança principalmente à população comum que não tem habilidade para manusear, nem as leis nem os mapas.

O Plano Diretor de Cuiabá tem como horizonte, segundo o art. $8^{\circ}$ do Plano Diretor de Desenvolvimento Estratégico - PDDE - o ano de 2022, com revisões programadas para cada oito anos ou quando necessário, sendo as ações desenvolvidas em curto prazo (até o ano de 2009), médio prazo (até o ano de 2014) e longo prazo (até o ano de 2022). 
O Plano Diretor de Várzea Grande diz que será revisto a cada dez anos, sendo que as matrizes de ações e diretrizes formuladas a partir das leituras técnica e comunitária estabelecem ações para serem desenvolvidas em curto (dois anos após promulgação do PD), médio (até cinco anos da promulgação do Plano Diretor), e longo prazo (até dez anos da promulgação do PD).

Para a análise das questões urbanísticas e institucionais foram considerados os Planos Diretores dos municípios estudados, o diagnóstico disponibilizado e a legislação municipal que complementa os Planos Diretores.

Os Princípios gerais adotados pelo Plano Diretor de Cuiabá, estão no o art. $5^{\circ}$ do atual Plano Diretor (vide anexo) e os princípios gerais do Plano Diretor de Várzea Grande estão no art. $7^{\circ}$ (vide anexo). Ambas as cidades almejam a promoção da qualidade de vida da população, a justiça social, direito à moradia, saúde, transporte, infraestrutura e participação na gestão da cidade. Assim convergem nos objetivos para a melhoria da qualidade de vida dos habitantes na localidade.

\section{4- FUNÇÃO SOCIAL DA PROPRIEDADE E DA CIDADE}

\subsection{1- FUNÇÃO SOCIAL DA PROPRIEDADE E DA CIDADE DE VÁRZEA GRANDE}

A preocupação com a função social da cidade não apareceu em nenhum dos planos anteriores, mas a função social da propriedade já aparecia no Plano Diretor de Desenvolvimento de Várzea Grande (1992), no capítulo IV, que dizia o seguinte:

“Art. 12 - Para cumprir sua função social art 196 , parágrafo $2^{\circ}$ da Lei Orgânica, a propriedade urbana deve atender, simultaneamente e segundo critérios e graus de exigências estabelecidas em Lei, no mínimo os seguintes requisitos:

I - Aproveitamento e utilização para atividades de interesse urbano, em intensidade compatível com a capacidade de atendimento dos equipamentos e serviços públicos;

II - Aproveitamento e utilização compatíveis com a preservação da qualidade do meio ambiente;

III - Aproveitamento e utilização compatíveis com a segurança e saúde de seus usuários e propriedades vizinhas".

"Parágrafo único - atividades de interesse urbano são aquelas inerentes às funções sociais da cidade e ao bem estar de seus habitantes, incluindo a moradia, a produção e o comércio de bens, a prestação de serviços, a circulação, a preservação do patrimônio cultural, histórico, ambiental e paisagístico e a preservação dos recursos necessários à cidade, tais como os mananciais hídricos e áreas urbanizadas". 
A questão da função social da cidade foi melhor esclarecida no Plano Diretor Participativo de 2007 elaborado por Várzea Grande. O art. $7^{\mathrm{a}}$ primeiramente estabeleceu como princípio geral a garantia da função social da cidade e da propriedade. Em seguida, na Seção I - Da Função Social da Cidade e da Propriedade, nos Art. 9, 10 e 11, foi esclarecido o que seria a considerado função social da cidade e da propriedade, inclusive estabelecendo que os instrumentos urbanísticos (de ordenamento do uso do solo) dispostos no Título IV do Plano, deverão ser utilizados em caso de afronta aos princípios.

Os princípios deverão nortear o desenvolvimento de políticas públicas e as ações nas cidades, e estão perfeitamente sintonizados, já que o desejo de uma cidade é praticamente o desejo da outra, porém não estabeleceram como princípio as discussões e o planejamento a nível de Aglomerado Urbano (ou Região Metropolitana).

\subsection{2- FUNÇÃO SOCIAL DA PROPRIEDADE E DA CIDADE DE CUIABÁ}

Em Cuiabá, o Plano Diretor de Desenvolvimento Urbano de Cuiabá que vigorou de 1992 até 2006 já tratava da função social da cidade e da propriedade no art. 3º, versando:

(...) "entende-se por Função Social da Cidade, aquela que se deve cumprir para assegurar as condições favoráveis ao desenvolvimento da produção econômica e, particularmente, para a plena realização dos direitos dos cidadãos". (parágrafo $1^{\circ}$ )

Então, o plano explicava que por direitos do cidadão compreendem-se as condições para que possa desenvolver suas potencialidades e a realização de suas aspirações, assim como a satisfação de suas necessidades básicas (direito a saúde, ao saneamento básico, à educação, ao trabalho, ao transporte coletivo, à moradia, à segurança, ao lazer e à participação social).

A Função Social da Propriedade Urbana seria atendida quando:

(...) "o uso da ocupação do solo responde às exigências fundamentais da sociedade, consolidadas nas Diretrizes do Plano Diretor, em conformidade com os dispositivos da instrumentação legal decorrente". (parágrafo $3^{\circ}$ ). 
A Função Social da Cidade e da Propriedade ainda aparecia como princípios do Plano Diretor de Desenvolvimento Estratégico (PDDE) de 2006, art. 5º é:

"IV - direito à Cidade para todos, compreendendo o direito à terra urbana, à moradia, ao saneamento ambiental, à infra-estrutura urbana, ao transporte, aos serviços públicos, ao trabalho e ao lazer;

V - respeito às funções sociais da Cidade";

O Plano de Cuiabá diz que todos possuem uma série de direitos, e que ao se respeitar estes direitos e buscar a sua concretização, se estaria respeitando as funções sociais da cidade, assim a questão já não era novidade.

Conhecidos os direitos de todos os cidadãos, resta colocar que só a partir da formulação de políticas públicas, de ações concretas em prazos determinados, avaliação constante dos resultados e por fim, um planejamento constante e uma administração bem preparada e democrática serão possíveis avaliar se os princípios e a função da cidade e da propriedade estão sendo conquistados e respeitados. 


\section{CAPÍTULO 05- CONTROLE DO USO E OCUPAÇÃO DO SOLO}

\section{1- CONTROLE DO USO E OCUPAÇÃo DO SOLO DE VÁRZEA GRANDE}

Durante os estudos técnicos para a elaboração do plano diretor de Várzea Grande foi constatado que existia uma cidade legal e outra, muito maior, que era a cidade real.

A VERTRAG contrapôs os usos do solo consolidados no território municipal àqueles definidos pela legislação vigente, e identificou o seguinte:

a) "a inexistência de mapa de zoneamento com a delimitação das zonas previstas pela Lei Municipal 1389/1994 torna inviável a aplicação da norma urbanística por parte do poder público municipal. Esta situação é agravada ao se verificar que, na correção de projetos de construção e parcelamento de solo e na liberação de licenças municipais, vem sendo utilizado um mapa de zoneamento anterior à lei vigente (MAPA de Zoneamento).

b) A área do território municipal ocupada com características de uso e parcelamento urbanos é maior que a poligonal do perímetro urbano delimitada pela Lei Municipal 2495/2002 (MAPA de Perímetro Urbano). Ou seja, a alteração do perímetro urbano, aprovada no ano de 2002, não veio acompanhada da adequação da legislação de zoneamento, gerando problemas de ordem fiscal, jurídica e fundiária.

c) $\mathrm{Na}$ leitura da cidade real não se observaram tipologias de uso e ocupação do solo urbano correspondentes às 20 (vinte) zonas previstas pela atual legislação.

d) Levando-se em conta os limites das zonas previstos no Mapa de Zoneamento que vem sendo adotado pelos técnicos municipais para a liberação dos alvarás municipais, as únicas onde se observa coerência entre a cidade real e a legal são a residencial e comercial.

e) A Lei Municipal 1389/1994 permite o parcelamento de imóveis rurais com objetivos de urbanização ou implantação de sítios de recreio. Tal situação, além de questionável sob o ponto de vista jurídico, tem produzido o surgimento de loteamentos periféricos, e possibilitado a reserva de propriedades urbanas vazias próximas à infra-estrutura, e que, portanto, não cumprem sua função social.

f) A deficiência observada nas normas urbanísticas vigentes tem reflexo direto sobre a qualidade de vida e o ambiente urbano. "Nas visitas de campo pôde-se verificar a existência de ocupação de áreas que deveriam ser destinadas à preservação permanente". (SİNTESE DA LEITURA TÈCNICA - VOL II, pág. 194).

Assim verifica-se que Várzea Grande é uma cidade que cresceu (e ainda cresce) sem planejamento urbano. Os núcleos habitacionais estão espalhados por uma grande área formando imensos vazios urbanos. Não se tem respeitado a legislação municipal, e isso tem acarretado dificuldades para atender a cidade com os serviços 
públicos e a infraestrutura adequada de forma que a qualidade de vida e a função social da cidade ficam comprometidas com este cenário.

O ordenamento do uso e ocupação do solo no município de Várzea Grande, teoricamente era realizado a partir da Lei de Zoneamento Urbano e do Código de Obras, em conformidade com o Plano Diretor de 1994, mas como ficou claro, a lei não era aplicada e na aprovação de projetos era utilizado o coeficiente de aproveitamento do lote igual a um e os recuos laterais mínimos iguais a 1,5. Se a edificação tivesse abertura, o frontal dependeria das edificações vizinhas, mas dependendo da conveniência, tudo isso não valia e a regra era aplicada caso a caso.

O Plano Diretor atual espacializou os usos e a ocupação através do zoneamento das atividades e da aplicação dos índices urbanísticos relacionados a cada uma das Zonas, definidas na Lei de Zoneamento, Uso e Ocupação do Solo Urbano, que é parte integrante do Plano Diretor (art. 29 do PDP), utilizando o mesmo método do antigo.

Com isto o poder público municipal pretende ter uma gestão eficiente e sustentável do território (art. 29 do PDP de VG), mas para tanto a lei deverá ser aplicada de acordo com o texto vigente, mudando inclusive práticas administrativas.

O Plano Diretor estabelece o Macrozoneamento Municipal, que foi definido conforme as características naturais, ambientais e porção já construída do território, e fixa diretrizes para o convívio entre atividades antrópicas e a conservação do patrimônio ambiental e cultural (art 31 do PDP de VG). O Macrozoneamento se divide em: Macrozona Rural (MR); Macrozona Rural de Interesse de Conservação e Preservação do Patrimônio Ambiental e Cultural (MRCP); Macrozona Urbana (MU).

A Zona Rural, conforme art. 33 do PDP de VG tem como referência o Zoneamento Ecológico Econômico do Estado do Mato Grosso e objetiva o incentivo às atividades agrosilvipastoris, de extração mineral e o turismo, incentivarem práticas adequadas de manejo, coibir o parcelamento irregular do solo caracterizado pelo parcelamento menor que o módulo rural mínimo do INCRA, permitir o uso industrial desde que se mantenha a baixa densidade, seja compatível com o local e a legislação ambiental, e recuperar matas ciliares.

A Macrozona Rural de Interesse de Conservação e Preservação do Patrimônio Ambiental e Cultural (art. 34 ), destina-se à proteção das áreas mais frágeis do território. Visa preservar as paisagens naturais, a qualidade das águas e os recursos hídricos, a cultura e as tradições de localidades tradicionais fora do perímetro urbano e fomentar o turismo com práticas sustentáveis. 
A Macrozona Urbana é a área que corresponde ao perímetro urbano e, portanto, delimita a área onde se aplicam as leis de zoneamento, uso, ocupação do solo e instrumentos do Estatuto da Cidade. Suas principais finalidades, consoante art. 35, são:

- O controle do adensamento urbano;

- Proteger da ocupação inadequada os sítios com fragilidades ou propícios à ocorrência de acidentes;

- Controlar a ocupação em áreas cuja infraestrutura está próxima da saturação;

- Reverter o processo de expansão periférica do tecido urbano e potencializar a utilização da infraestrutura;

- Promover a regularização fundiária articulando sustentabilidade ambiental e inclusão socioespacial;

- Proteger da ocupação sítios com fragilidades ou risco de ocorrência de acidentes;

- Proporcionar boas condições de circulação em todos os pontos da cidade;

- Racionalizar os investimentos públicos;

- Qualificar a paisagem urbana.

Para tanto, a Macrozona Urbana foi dividida em três grandes áreas, definidas a partir do grau de urbanização e do padrão de uso e ocupação desejável para a área, sendo elas:

- A Área Urbana de recuperação, conservação e preservação do patrimônio ambiental e cultural, destinada à preservação do patrimônio natural e cultural, proteger sítios frágeis ou sujeitos a riscos de acidentes ambientais da ocupação. Nesta área haverá a geração de potencial construtivo através da aplicação do instrumento da Transferência do Direito de Construir.

- A Área Urbana de Ocupação Controlada, com objetivo de controlar a densidade, minimizar os riscos de acidentes ambientais, controlarem a ocupação de áreas onde a infraestrutura se encontra próxima da saturação, ampliar os espaços verdes e as áreas de lazer e requalificar a paisagem urbana. Aqui haverá a aplicação do instrumento da Outorga Onerosa do Direito de Construir.

- A Área Urbana de Intensificação da Ocupação visa potencializar o uso da infraestrutura existente e complementá-la nas áreas desatendidas; implantar 
equipamentos públicos, áreas verdes e de lazer; atender o princípio da função social da propriedade e da cidade; racionalizar os investimentos públicos a partir da implantação de ações articuladas entre as diversas políticas setoriais; incentivar o parcelamento e a ocupação de áreas urbanas sem utilização ou subutilizadas, com prioridade para a produção de habitação de interesse social; e viabilizar a urbanização e a regularização fundiária dos núcleos habitacionais de baixa renda localizados dentro do perímetro urbano. Esta área se permitirá a autorizada e a aplicação do instrumento do Parcelamento, edificação ou utilização compulsórios, IPTU progressivo no tempo, Desapropriação com pagamento em títulos da dívida pública, a recepção de Potencial Construtivo através da aplicação da Transferência do Direito de Construir e o exercício do Direito de Preempção, nos termos da legislação específica.

Verifica-se que o Perímetro Urbano, que é delimitado pela Macrozona Urbana, foi subdividido em diversas Zonas (art. 17), segundo suas características, como a seguir:

I. Zona de Conservação e Preservação Ambiental (ZCP), definindo as áreas que não poderão ser habitadas nem utilizadas, ou com restrições na sua ocupação devido a razoes ambientais;

II. Zona Especial de Interesse Cultural, Ambiental e Turístico (ZCAT), em locais onde é desejável preservar suas características;

III. Zona de Proteção do Aeroporto (ZPA);

IV. Zona de Serviços (ZS), incluindo as centralidades de bairros;

V. Zona Industrial (ZI), sendo caracterizada pelos distritos industriais;

VI. Zona Predominantemente Residencial (ZR);

A classificação de usos do solo admitidos em cada Zona, assim como os parâmetros e índices urbanísticos, consta nas Tabelas I, II, III e IV que integram a Lei.

O perímetro urbano de Várzea Grande havia sido instituído pela lei 2.485/2002 que diminuiu a área urbana e excluiu alguns loteamentos já aprovados e algumas localidades urbanizadas e ocupadas. Isso aconteceu sem que se tivesse alterado a lei de zoneamento, e causou diversas confusões de ordem jurídica, tributária (o município deixou de receber o IPTU destas localidades) e prejuízos para o ordenamento territorial. Esta lei fazia referência a um mapa, mas nenhuma cópia foi disponibilizada à população (e nem os técnicos da prefeitura a conheciam). O mapa utilizado para verificação do perímetro urbano não era o que foi instituído pela lei, o que causa ainda mais confusão. 
O novo perímetro organizou a confusão, mas ainda é fonte de discussão, pois continuou com a configuração diminuída em relação ao estabelecido junto com o Plano Diretor de 1994, e assim já existem discussões para se aumentar o Perímetro Urbano.

De forma geral, a diminuição do perímetro não será prejudicial ao acesso à terra pela população mais pobre, tendo em vista a existência de grandes áreas desocupadas dentro do Perímetro Urbano.

O perímetro urbano delimita o que é considerado Macrozona Rural e o que é a Macrozona Urbana.

Quadro 04 - Parâmetros de uso e ocupação do solo. Fonte: Plano Diretor de 2007 Anexo II - Parâmetros de Uso e Ocupação das Macrozonas Municipais

\begin{tabular}{|c|c|c|c|}
\hline MACROZONA & LOTE MINIMO & $\begin{array}{l}\text { COEFICIENTE } \\
\text { APROVEITAMENTO }\end{array}$ & USOS PREDOMINANTES? \\
\hline Macrozona Rural & Módulo INCRA & - & $\begin{array}{l}\text { - Atividades agrosilvjpastoris } \\
\text { e de extração mineral; } \\
\text { - Turismo; } \\
\text { - } \quad \text { Preservação, conservaçẫo } \\
\text { e recuperação dos remanescentes } \\
\text { vegetais e da mata ciliar. }\end{array}$ \\
\hline $\begin{array}{l}\text { Macrozona Rural de Interesse de } \\
\text { Conservaçẫo e Preservaçẫo do } \\
\text { Patrimônio Ambiental e Cultural }\end{array}$ & Módulo INCRA & - & $\begin{array}{ll}\text { - } & \text { Atividades agrosilvipastoris: } \\
\text { - } & \text { Turismo; } \\
\text { e recuperaçervação, conservação patrimônio } \\
\text { natural e cultural. }\end{array}$ \\
\hline Macrozona Urbana & $\begin{array}{l}\text { Conforme Lei de Zoneamento de } \\
\text { Uso e Ocupaçấo do Solo Urbano }\end{array}$ & $\begin{array}{l}\text { Conforme Lei de Zoneamento de } \\
\text { Uso e Ocupação do Solo Urbano }\end{array}$ & $\begin{array}{l}\text { Habitaçãa, Comércio, } \\
\text { Serviços, Institucional e Industrial, } \\
\text { de acordo com a Lei de } \\
\text { Zoneamento de Uso e Ocupação } \\
\text { do Solo Urbano. }\end{array}$ \\
\hline
\end{tabular}

${ }^{1}$ Em todas as macrozonas deverẫo ser respeitados o Código Florestal Brasileiro (Lei Federal 4771/1965).

Fonte - Plano Diretor de Várzea Grande de 2007 
Tabela 2 - Zoneamento de Várzea Grande

Tabela III - Parâmetros de Uso e Ocupação do Solo 1

\begin{tabular}{|c|c|c|c|c|c|c|c|}
\hline \multirow{2}{*}{ Zonas } & \multirow{2}{*}{$\begin{array}{l}\text { Característica da área ondeo } \\
\text { imóvel está inserido }\end{array}$} & \multicolumn{2}{|c|}{ Lote } & \multicolumn{3}{|c|}{ Coeficiente de Aproveitamento. } & \multirow{2}{*}{$\begin{array}{l}\text { Instrumento do Estatuto } \\
\text { da Cidade }\end{array}$} \\
\hline & & Fração Mírima $\left(\mathrm{m}^{x}\right)$ & Frente Mírima (m) & Mínimo & básico & Extra (1) & \\
\hline \multirow{2}{*}{$\mathrm{ZCP}$} & $\begin{array}{l}\text { Fora dos limites das Areas de } \\
\text { Preservaçäo Permanerte }\end{array}$ & $5.000,00$ & 20,00 & \multirow{2}{*}{ - } & \multirow{2}{*}{0,05} & \multirow{2}{*}{ - } & \multirow{2}{*}{$\begin{array}{l}\text { Gera potencial construtivo } \\
\text { para transterëncia }\end{array}$} \\
\hline & $\begin{array}{l}\text { Dentro dos limites das Areas de } \\
\text { Presenuaçäo Permanerte }\end{array}$ & (2) & (2) & & & & \\
\hline ZCAT & $\cdot$ & 360,00 & 12,00 & - & 1. & $\cdot$ & $\begin{array}{l}\text { Gera potencial corstritivo } \\
\text { para transferëncia }\end{array}$ \\
\hline ZPA & - & (3) & (3) & - & (3) & - & $\cdot$ \\
\hline zs & - & 1500,00 & 20,00 & (4) & 0.6 & - & - \\
\hline $\mathrm{ZI}$ & - & 1500,00 & 20,00 & (4) & 1 & - & - \\
\hline \multirow{4}{*}{$\mathrm{ZR}$} & $\begin{array}{l}\text { Nowos parcelamentos irseridos na } \\
\text { Area de 0cupaçäo Controlada - Setor } \\
1\end{array}$ & 360,00 & 12,00 & - & 0,8 & 1. & $\begin{array}{c}\text { Outorga Onerosa do Direito } \\
\text { de Construir }\end{array}$ \\
\hline & $\begin{array}{l}\text { Nowos parcelamentos inseridos na } \\
\text { Area de Irtensifica̧̧äo da 0cupaçäo- } \\
\text { Setor } 2\end{array}$ & 250,00 & 10,00 & 0,2 & 1. & 2,5 & $\begin{array}{l}\text { - Recebe potencial } \\
\text { construtưo portransferëncia. } \\
\text { - Parcelamerto, edificaçẫo e } \\
\text { utilizaçäo compulsórios. }\end{array}$ \\
\hline & 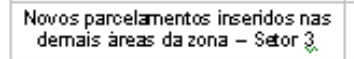 & 360,00 & 12,00 & $\cdot$ & 1 & - & $\cdot$ \\
\hline & $\begin{array}{l}\text { Regulanzaçao tundiana de lates ou } \\
\text { fraçöes de lates existertes e } \\
\text { edificados. (5) }\end{array}$ & 180,00 & 10,00 & - & 0.4 & 1. & \\
\hline \multirow{4}{*}{ ZUM } & $\begin{array}{l}\text { Nowos parcelamentos irseridos na } \\
\text { Area de Ocupaça Controlada - Seror } \\
4\end{array}$ & 360,00 & 12,00 & - & 0,8 & 1. & \\
\hline & $\begin{array}{c}\text { Nowos parcelamentos inseridos na } \\
\text { Area de Irtensifica̧äo da 0cupaçäo- } \\
\text { Setor } 5\end{array}$ & 360,00 & 12,00 & 0,2 & 1. & 2,5 & $\begin{array}{c}\text { Recebe potencial construtivo } \\
\text { por transterëncia } \\
\text { Parcelamento, edificą̧̃o e } \\
\text { utilizaçäo compulsónos. }\end{array}$ \\
\hline & $\begin{array}{l}\text { Nowos parcelamentos irseridos nas } \\
\text { demais areas da zona - Setor } 6\end{array}$ & 360,00 & 12,00 & - & 1 & $\cdot$ & $\cdot$ \\
\hline & $\begin{array}{l}\text { Regularizaçäo fundiäria de lates ou } \\
\text { iraçöes de lates existertes e } \\
\text { edificados. (5) }\end{array}$ & 180,00 & 10,00 & - & 0.4 & 1. & \\
\hline
\end{tabular}

(1) Quando não existir coeficiente de aproveitamento máximo adotar o básico como potencial construtivo máximo.

(2) Proibido parcelamento do solo.

(3) De acordo com o Plano de Desenvolvimento Aeroportuário.

(4) $\mathrm{Em}$ caso de lotes que receberam ou vierem a receber algum tipo de incentivo público para instalação de atividades econômicas, o coeficiente de

ap roveitamento mínimo será 02 , sob pena de aplicaçâo dos instrumentos urb anísticos de parcelamento, edificação e utilizaçấo compulsórios, nos termos

da lei específica, revogação da doaçäo, ou devoluçãa do incentivo conce dido pelo poder público.

(5) Possivel apenas para as construçốes existentes e consolidadas até a data da aprovação desta lei, o que deverá ser devidamente comprovado ao

órgão municipal competente, atendido, ainda, o disposto no art. 30 da presente lei.

Fonte - Plano Diretor de 2007

A Lei Do Zoneamento de Uso e Ocupação do Solo Urbano (Art. 8) define o que é permitido, permissível, tolerado e proibido.

O Plano não prevê área de expansão urbana, nem Zona de Expansão Urbana, o que se justifica pelas imensas áreas vazias dentro da Zona Urbana, que deverão ser ocupadas prioritariamente, evitando que cada vez mais, os munícipes tenham que morar longe das áreas comerciais e de serviços, em localidades desarticuladas do tecido urbano, com alto custo para se levar a estas localidades a infra-estrutura adequada, e tendo sua qualidade de vida bastante comprometida. 
Tabela 03 - Classificação dos usos de Várzea Grande

TABELA II - CLASSIFICAÇAO DE USOS

\begin{tabular}{|c|c|c|c|c|}
\hline ZONA & PERMITIDO & PERMISSIVEL [1] & TOLERADO & PROIBIDO \\
\hline $\mathrm{ZCP}$ & 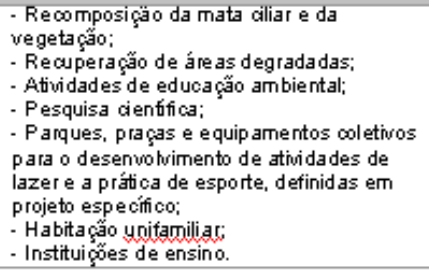 & $\begin{array}{l}\text { - Habitaç̧̃o de uso institucional; } \\
\text { - Habitaçẫo transitónia. }\end{array}$ & $\begin{array}{l}\text { - Uso extrativista apenas } \\
\text { no rio Cuiabá: } \\
\text { - Uso agropecuário. }\end{array}$ & $\begin{array}{l}\text { - Todos os demais usos } \\
\text { - Uso de agrotóxicose } \\
\text { outros biocidas. }\end{array}$ \\
\hline ZCAT & $\begin{array}{l}\text { - Habitação ynitamiliad: } \\
\text { - Habitaços ynitamiliares em série; } \\
\text { - Comércio senvico vicinal: } \\
\text { - Comércio e senvico de bairro: } \\
\text { - Micro-indústria do Grupo A. }\end{array}$ & $\begin{array}{l}\text { - Habitaç̧̃o de uso institucional; } \\
\text { - Habitaçâo transitónia; } \\
\text { - Indústrias Grupo } \mathrm{B}(2)\end{array}$ & - Uso agropecuário. & - Todos os demais usos. \\
\hline ZPA & $\begin{array}{l}\text { - Recomposição da mata ciliar e da } \\
\text { vegetaçăo: } \\
\text { - Recuperação de áre as degradadas; } \\
\text { - Comércio e seniços gerais ( } 3 \text { ). }\end{array}$ & $\begin{array}{l}\text { - Habitaçãa transitónia: } \\
\text { - Comércio e seniço setoriais. }\end{array}$ & - & $\begin{array}{l}\text { - Todos os demais usos. } \\
\text { - Uso de agrotóxicose } \\
\text { outros biocidas. }\end{array}$ \\
\hline zs & $\begin{array}{l}\text { - Comércio e senicos gerais; } \\
\text { - Comércio e servicos setoriais; } \\
\text { - Indústrias Gupo A, de pequeno e médio } \\
\text { porte: } \\
\text { - Indústrias Gupo } \mathrm{B} \text {, de pequeno e médio } \\
\text { porte. }\end{array}$ & - Comércio e seniços espeáficos. & - Habitação ynitamiliar. & - Todos os demais usos. \\
\hline $\mathrm{Zl}$ & $\begin{array}{l}\text { - Comércio e senvicos gerais; } \\
\text { - Indústrias Gupo } \mathrm{A}_{\text {; }} \\
\text { - Indústrias Gupo } \mathrm{B} \text { : } \\
\text { - Indústrias Gupo } \mathrm{C} \text {. }\end{array}$ & - Comércio e seniços espeáficos. & $\begin{array}{l}\text { - Habitação ynitamiliar; } \\
\text { - Uso agropecuario. }\end{array}$ & - Todos os demais usos \\
\hline $\mathrm{ZR}$ & 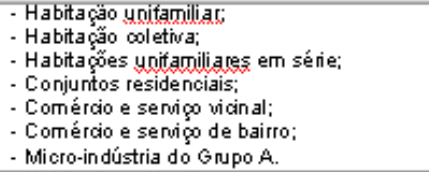 & $\begin{array}{l}\text { - Habitação de uso institucional; } \\
\text { - Comércio e senicos espeáficos; } \\
\text { - Comércio e sencocos setoriais; } \\
\text { - Indústria de pequeno porte Grupo A. }\end{array}$ & - & $\begin{array}{l}\text { - Todos os demais usos; } \\
\text { - Atividades incômodas, } \\
\text { nociuas e perigosas. }\end{array}$ \\
\hline ZUM & 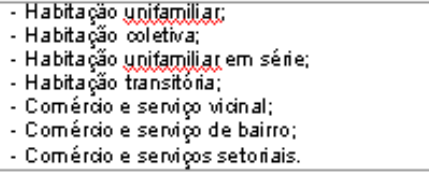 & $\begin{array}{l}\text { - Habitação de uso institucional; } \\
\text { - Comércio e seniços gerais: } \\
\text { - Comércio e servico espeáfico: } \\
\text { - Micro-Indústria e indústria de pequeno } \\
\text { porte do Grupo A }\end{array}$ & - & - Todos os demais usos \\
\hline
\end{tabular}

OBSERVAÇÕES:

(1) Na ZPA, além das demais exigências estabelecidas pela presente lei, a autorização dos usos permissíveis está vinculada às diretrizes definidas pelo Plano de Desenvolvimento Aeroportuário.

(2) Uso permissível apenas para os lotes com frente para a BR-163, e nos demais lotes da zona este uso é proibido.

(3) Permitido somente para as atividades de transporte e atividades de Comércio e Serviços Gerais diretamente ligadas às de transporte. As demais atividades relacionadas a este uso serão consideradas proibidas.

(4) Na ZPA, além das demais exigências estabelecidas pela presente lei, a autorização dos usos permissíveis está vinculada às diretrizes definidas pelo Plano de Desenvolvimento Aeroportuário.

(5) Uso permissível apenas para os lotes com frente para a BR- 163, e nos demais lotes da zona este uso é proibido.

(6) Permitido somente para as atividades de transporte e atividades de Comércio e Serviços Gerais diretamente ligadas às de transporte. As demais atividades relacionadas a este uso serão consideradas proibidas.

Fonte - Plano Diretor de Várzea Grande de 2007

Apesar de existir a classificação dos usos, basta observar a cidade para concluir que não são aplicados com rigor, de modo que se observa usos variados em todos os locais, sendo perfeitamente tolerados pela municipalidade. Isto se deve também a falta de hábito da população em aprovar projetos e solicitar habite-se e na frágil fiscalização, que não sendo eficaz deixa margem para a ilegalidade. 


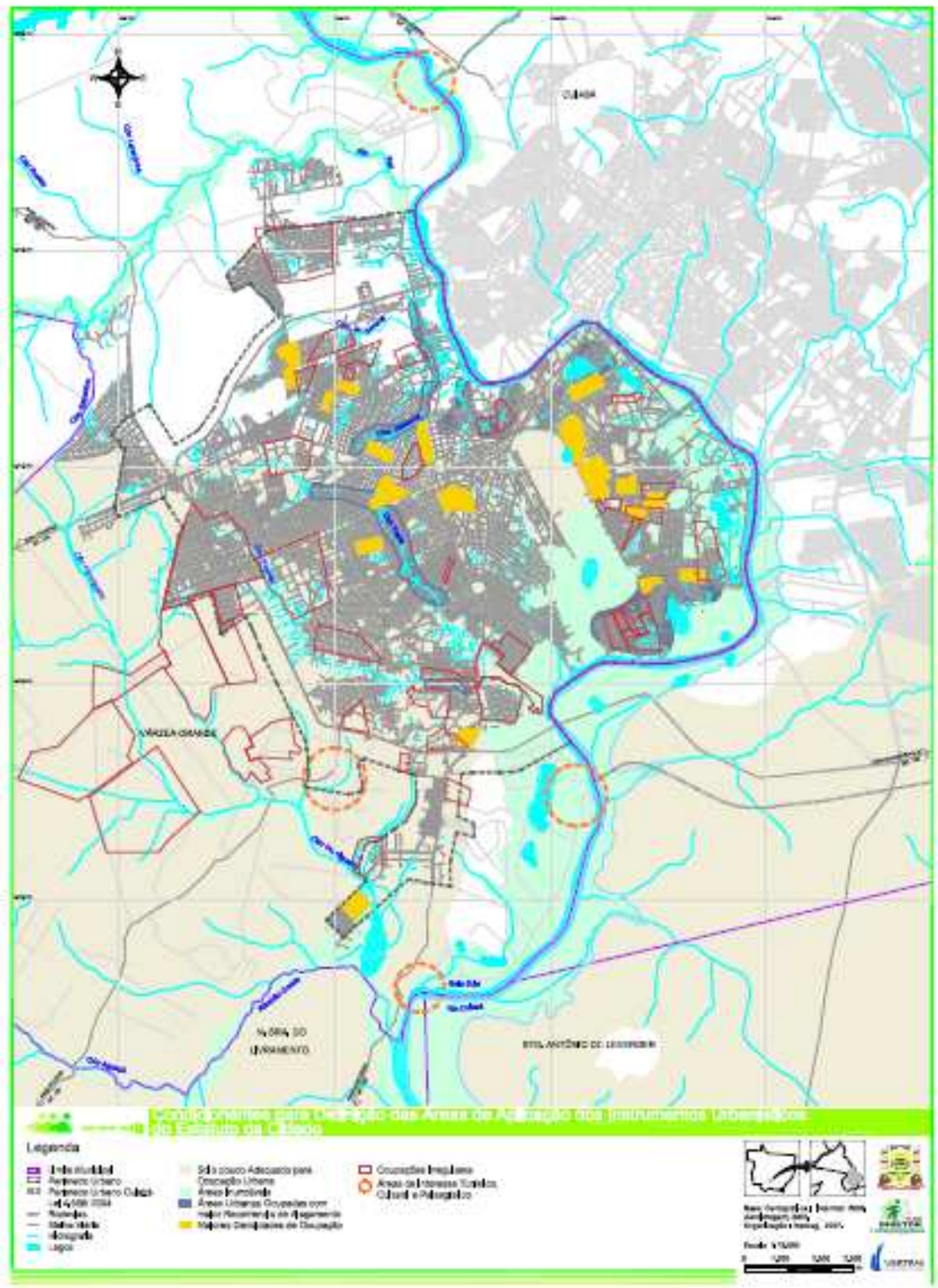

Figura 12 - Condicionantes para Definição das Áreas de Aplicação dos Instrumentos Urbanísticos.

Fonte - VERTRAG 


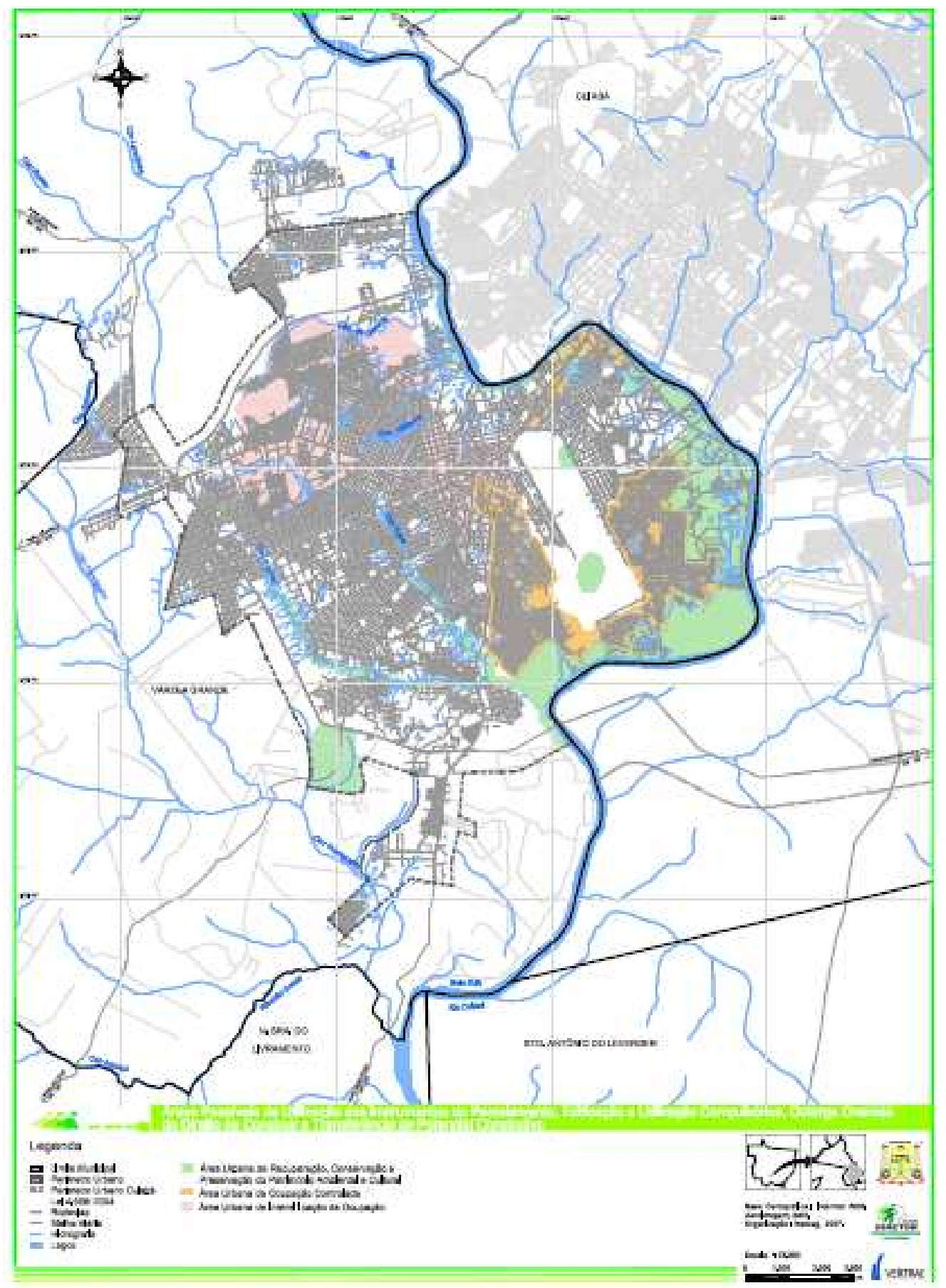

Figura 13 - Áreas Passíveis de Aplicação dos Instrumentos do Estatuto da Cidade Fonte - VERTRAG 


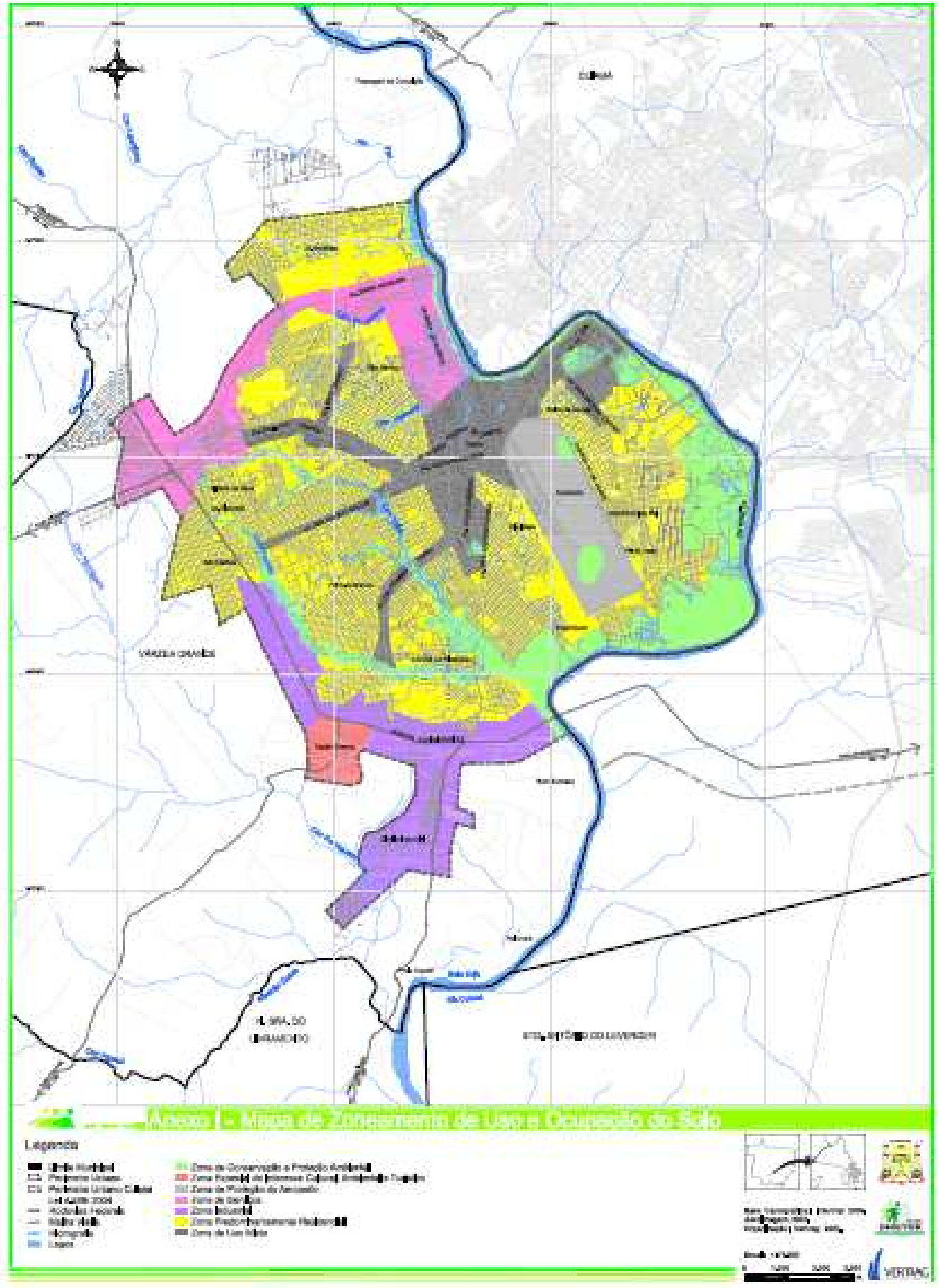

Figura 14 - Zoneamento de Várzea Grande Fonte - VERTRAG 


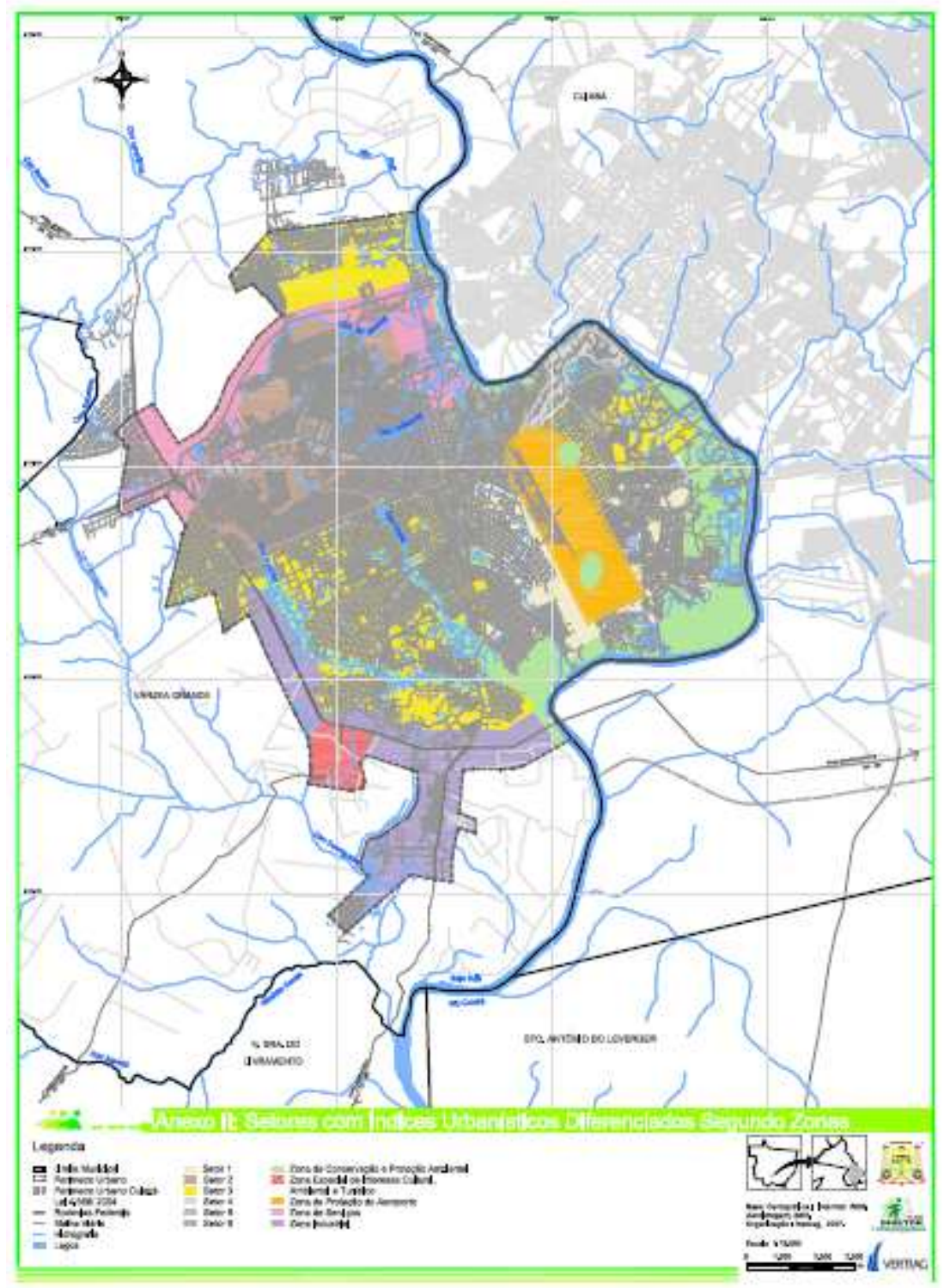

Figura 15 - Índices Urbanísticos de Várzea Grande Fonte - VERTRAG 


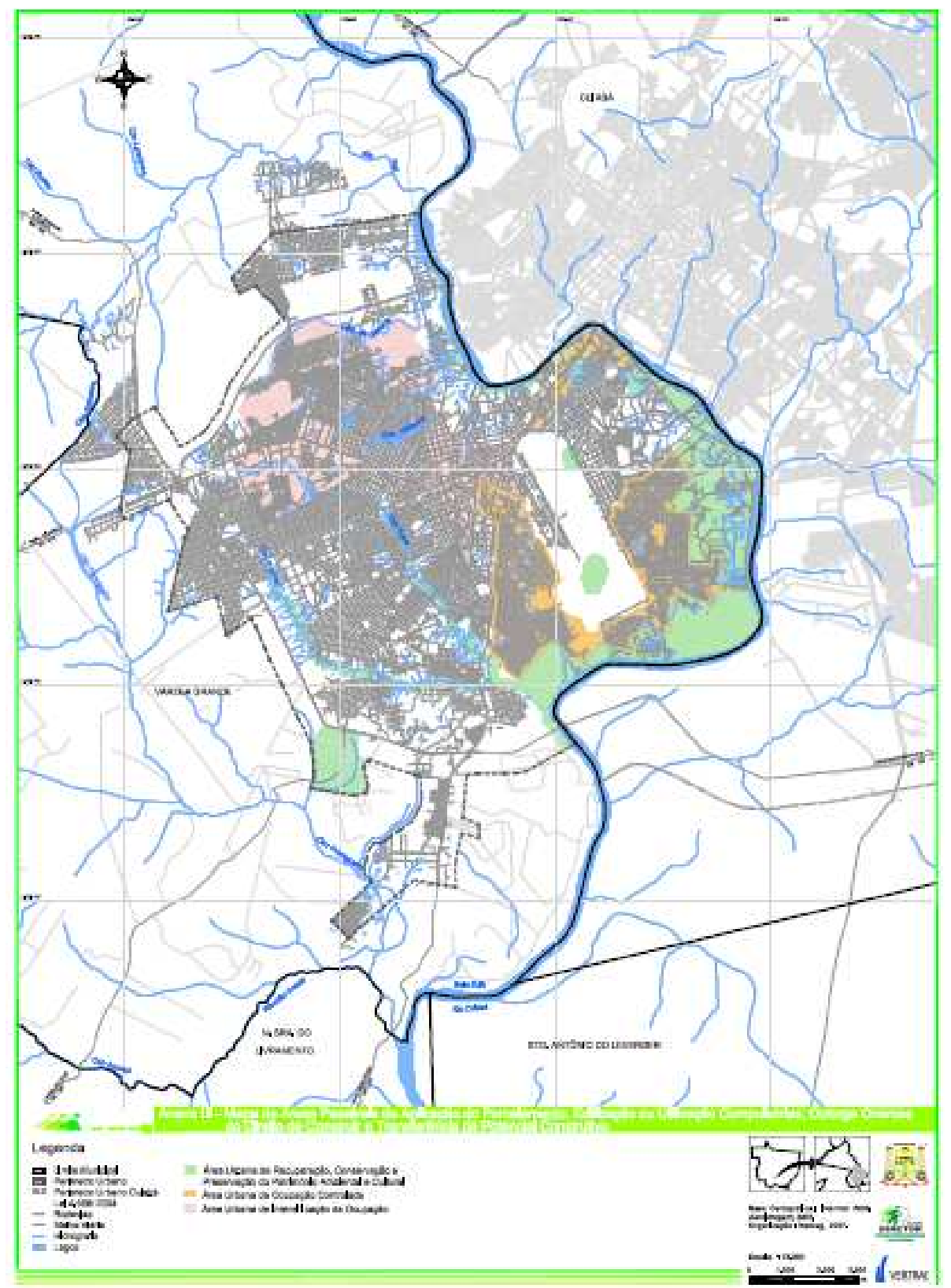

Figura 16 - Áreas Prioritárias para aplicação de ZEIS em Várzea grande Fonte - VERTRAG 2007 
Zoneamento e dos índices urbanísticos, o Plano Diretor de Várzea Grande se valeu dos instrumentos contidos no Estatuto da Cidade para o controle do uso do solo. Foi produzido o mapeamento das áreas passíveis de se instituir os instrumentos do Estatuto da Cidade, mas outros mapas deverão ser elaborados com base em lei, visto que os apresentados pela consultoria - VERTRAG - são apenas para basear as leis a serem produzidas. Os instrumentos estão abaixo apresentados.

\section{a) Edificação/Parcelamento Compulsórios IPTU progressivo no tempo e}

\section{Desapropriação}

Visando o cumprimento da função social da cidade e da propriedade, através da indução da ocupação das áreas vazias dotadas de infra-estrutura e serviços urbanos, o art. 44 dispõem que o poder público municipal poderá exigir do proprietário do imóvel urbano não edificado, subutilizado, utilizado inadequadamente ou não utilizado, que promova seu adequado aproveitamento, sob pena de parcelamento, edificação ou utilização compulsórios, podendo o proprietário propor ao poder público a celebração de consórcio imobiliário para a sua utilização. Quando o proprietário não promover seu aproveitamento, ficará sujeito ao IPTU progressivo durante cinco anos (art. 47) e depois é facultado ao poder público que promova a desapropriação do imóvel com pagamento de títulos da dívida pública (art. 49). Conforme art. 46, o instrumento poderá ser aplicado na Área de Intensificação de Ocupação, definida na Lei.

Considera-se subutilizado, sem prejuízo a outros casos que poderão ser definidos em legislação específica (art. 45):

I. "Imóvel urbano com área superior a $3.000 \mathrm{~m}^{2}$ (três mil metros quadrados) cujo coeficiente de aproveitamento seja inferior ao mínimo estabelecido pela Lei de Zoneamento do Uso e Ocupação do Solo Urbano;

II. Edificação desocupada há mais de 5 (cinco) anos”.

O Plano Diretor exclui da obrigação os imóveis nas seguintes condições (art. 45, $\left.\S 2^{\circ}\right)$ :

I." Garagem de veículos de transporte de passageiros;

II. Exercendo função ambiental;

III. De interesse social, ambiental e como patrimônio cultural;

IV. Ocupados por clubes ou associações de classe;

V. Imóveis integrantes de massa falida". 
O instrumento não tem sido utilizado por falta de legislação específica que estabeleça as localidades, os casos de forma geral, as alíquotas e procedimentos.

\section{b) Outorga Onerosa do Direito de Construir}

É faculdade concedida ao proprietário de imóvel, para que este, mediante contrapartida ao poder público municipal, possa construir acima do coeficiente de aproveitamento básico até o limite estabelecido pelo coeficiente de aproveitamento máximo permitido para a zona (art. 60), porém é também faculdade conferida ao poder público a outorga do direito de construir, mediante contrapartida (art. 61).

Contudo, o instrumento dependerá de legislação específica, estabelecendo os procedimentos e as circunstâncias para ser utilizado de forma transparente e democrática.

\section{c) Transferência de Potencial Construtivo}

Conforme lei específica a ser elaborada, o poder público poderá, segundo o art. 67 do Plano Diretor, permitir como compensação, ao proprietário de imóveis sobre o qual insere um interesse público, a transferência do potencial construtivo para outro local. As áreas prioritárias para receber o acréscimo se localizam na Área de Intensificação da Ocupação e as ZEIS (art. 67), e as áreas geradoras são as Áreas Urbanas de Recuperação, Conservação e Preservação do Patrimônio Ambiental e Cultural. Porém, deverão ser observados os limites conforme as tabelas de uso e ocupação do solo (Anexo III do PDP). Sem a lei e sem "papas", o instrumento não tem sido aplicado.

\section{d) Operações Urbanas Consorciadas}

O Plano Diretor compreende como operação urbana consorciada (art. 72), o conjunto de intervenções e medidas coordenadas pelo poder público municipal, com a participação dos proprietários, moradores, usuários permanentes e investidores privados, com o objetivo de alcançar, em uma área, transformações urbanísticas estruturais, melhorias sociais e a valorização ambiental. Cada operação deverá ser aprovada por Lei específica, conforme o que estabelece o art. 32 da Lei 10.257 / 2001 (Estatuto da Cidade) e art. 74 do PDP. Ainda não existe nenhum caso no município de Operação Urbana Consorciada. 


\section{e) EIV Estudo de Impacto de Vizinhança}

O art. 81 estabelece que Lei Municipal poderá submeter alguns empreendimentos considerados impactantes do ponto de vista urbanístico e ambiental, a elaboração e aprovação do Estudo de Impacto de Vizinhança.

Consoante art. 82, poderá o poder público, através de Lei específica, submeter ao EIV:

I. "Parcelamentos urbanos com área total igual ou superior a 300.000 $\mathrm{m}^{2}$ (trezentos mil metros quadrados) ou quaisquer parcelamentos localizados na Área Urbana de Ocupação Controlada;

II. Empreendimentos comerciais com área construída total superior a $5.000 \mathrm{~m}^{2}$ (cinco mil metros quadrados);

III. Cemitério, crematórios e capelas mortuárias;

IV. Plantas industriais com mais de $1.000 \mathrm{~m}^{2}$ (mil metros quadrados) de área construída e quaisquer empreendimentos industriais situados na área rural do Município;

V. Aterros sanitários ou outros depósitos de resíduos sólidos;

VI. Presídios".

A lei municipal poderá definir outros empreendimentos e atividades a elaboração e aprovação do EIV.

O EIV deverá esclarecer os aspectos positivos e negativos e qual o impacto sobre a qualidade de vida da população. Deverá conter no mínimo os estudos solicitados no Estatuto da Cidade, sendo analisados, conforme art. 83 deste documento:

Poderão ser exigidas medidas mitigadoras para os impactos negativos do empreendimento, como disponibilidade de cotas de emprego, oferta de cursos profissionalizantes para a população, e/ou melhorias na infra-estrutura e equipamentos urbanos (art. 84).

O EIV não substituirá o Licenciamento Ambiental (art. 85) e todos os documentos integrantes do processo de EIV deverão ficar disponíveis para que qualquer interessado possa conhecê-los, dando-se assim ampla publicidade sobre o empreendimento (art. 86).

Segundo o $\S 2^{\circ}$ do art. 85 :

"Antes da decisão sobre o projeto, o órgão público responsável pelo exame do EIV deverá realizar audiência pública com os moradores da área afetada ou com suas respectivas associações".

Este instrumento tem sido exigido nos casos de empreendimentos mais impactantes 


\section{f) ZEIS}

As ZEIS, conforme art. 90 são áreas urbanas delimitadas pelo poder público municipal, que se sobrepõem ao Zoneamento Urbano Municipal, e serão permitidas por meio da elaboração de um plano urbanístico próprio, e lei própria que poderá estabelecer padrões de uso e ocupação diferenciados da legislação em vigor. Contudo, o mapa de zoneamento traz a demarcação de algumas áreas para ZEIS, embora não as vincule a uma lei especial e nem a critérios diferenciados. O zoneamento do Plano Diretor chega a sobrepor ZEIS com área de Conservação Ambiental (por já estar habitada com famílias de baixa renda). Mas a princípio serão aplicadas nas áreas definidas no Plano Diretor, anexo IV, e onde lei especial ainda não elaborada permitir. Se observa que a construção de habitações populares pode ocorrer em qualquer local do município, com poucas restrições, sendo que não se terá nenhuma dificuldade para promover habitações de interesse social em Várzea Grande, inclusive pelo preço da terra no local.

\section{g) Concessão de Uso Especial para Fim de Moradia}

Aqueles que habitam áreas públicas do município por cinco anos ou mais, ininterruptamente (até o dia 30 de junho de 2001), terão direito de manter a posse para continuar residindo no local conforme o art. 94. Mas deverá ser elaborada uma Lei para especificar os casos, e deverá atender ainda a medida provisória 2.220 (art. 94). O instrumento aguarda a elaboração do Plano de Habitação para surtir efeitos a partir do conhecimento de quantas famílias se encontram nesta situação e assim estabelecer um plano de ação.

\section{h) Direito de Superfície}

Poderá ser autorizado pelo município, o direito de superfície, não sendo delimitada área da cidade e nem especificando condições para tanto. $\mathrm{O}$ instrumento não depende de Plano Diretor para ser utilizado, sendo acordo entre as partes, porém não poderá desrespeitar a legislação urbana e municipal.

\section{i) Direito de Preempção}

$\mathrm{O}$ art. 57 confere ao poder público a preferência para a aquisição de imóvel urbano, objeto de alienação onerosa entre particulares, caso necessite de áreas para: 
I. "Regularização fundiária;

II. Execução de programas e projetos habitacionais;

III. Implantação de equipamentos urbanos e comunitários;

IV. Ordenamento e direcionamento da expansão urbana;

V. Criação de espaços públicos de lazer e áreas verdes;

VI. Criação de unidades de conservação ou proteção de outras áreas de interesse ambiental;

VII. Proteção de áreas de interesse histórico, cultural e paisagístico. E nos termos do art. 26 e 27 do Estatuto da Cidade".

Segundo o Art. 59 do PDP,

“o Poder Público Municipal delimitará, por meio de lei específica, as áreas em que concretamente incidirá o direito de preempção, definindo procedimentos e fixando prazos de vigência, que não poderão exceder a 5 anos, renováveis por igual período".

Não existe ainda a lei e, portanto, o instrumento não tem sido utilizado.

\section{j) Consórcio Imobiliário}

Segundo o art. 52, este instrumento será utilizado para proporcionar melhorias em áreas da cidade que tenham carência de infra-estrutura e serviços urbanos, que contenham imóveis urbanos subutilizados, não utilizados ou utilizados inadequadamente ou que necessitem de intervenções urbanísticas. Tem em vista a cooperação entre o poder público e o setor privado. Não se conhece casos de consórcio imobiliário na cidade de Várzea Grande ainda.

\section{2- AÇÕES PARA CONTROLE DO USO E OCUPAÇÃO DO SOLO} EM V. GRANDE

Atualmente a Secretaria de Obras é a responsável pela aprovação de projetos, pela fiscalização do uso e ocupação do solo, incluindo as construções realizadas pelo setor privado e a população em geral. Porém a Secretaria de Meio Ambiente se manifesta sobre as obras mais impactantes, quando os processos são encaminhados para exame.

Apesar de decorridos dois anos da aprovação do atual plano diretor, nem o setor de aprovação de projetos e nem o setor de fiscalização estão estruturados para realizar suas funções. Atualmente a fiscalização conta com cinco fiscais trabalhando em meio período para a fiscalização de toda a cidade e de todas as atividades referentes a obras e posturas. Estes fiscais não cumprem rotinas e as condições de trabalho são precárias 
faltando veículos e materiais básicos. Existe a queixa de que suas notificações e multas acabam sem efeito quando recorridas, desmoralizando a fiscalização, e conforme a época e interesses políticos, por tempos foi costume abrandar a fiscalização para não causar problemas com a população.

O setor de aprovação também sofre pressão política, e não são raras obras sendo aprovadas em desconformidade com a lei. À bem da verdade deve-se dizer que a lei aplicada não é bem a que está em vigor. Segundo técnicos da Coordenadoria de Projetos, única responsável por todas as aprovações de projetos que dão entrada no protocolo, se utilizava e continua-se utilizando, o coeficiente de aproveitamento de $1 \mathrm{e}$ recuo frontal variando de 3 a 5 metros para todas as localizadas da cidade, com exceção dos projetos localizados nos corredores estruturais onde se exige recuos maiores conforme a localidade. Quando questionada sobre a aplicação do atual plano diretor, a resposta foi que estava sendo cumprido em partes, sendo que os índices urbanísticos não estavam sendo aplicados por falta de descrição do perímetro das Zonas delimitadas no mapa de Uso e Ocupação do Solo que integram o Plano Diretor de Várzea Grande. Quanto à regularização fundiária, também não se aplica o índice da tabela contida no Plano, mas não por ser este índice muito baixo, impedindo a regularização de grande parte de imóveis, e nem pela falta de regras específicas, mas não se aplica porque as regras são as mesmas para a aprovação de projetos, que também não seguem o Plano Diretor. Por ser mais benéfica à população e beneficiar especialmente aos mais influentes, estas questões não levantam polêmicas, mas vem prejudicando a cidade em geral, pois geram fragilidades ambientais, problemas com insalubridade das moradias e dos bairros, construções clandestinas e não raramente, problemas de vizinhança.

Desta forma, a primeira medida que se faz necessária é a reestruturação do sistema de aprovação de projetos e de fiscalização, criando rotinas de trabalho, aplicação das leis e divulgação junto à população, tanto das leis edilícias quanto dos benefícios de se estar com seu imóvel legalizado. Também será de suma importância a elaboração das leis para que a prefeitura possa utilizar os instrumentos de controle urbano, pois isto proporcionaria condições para forçar a ocupação dos espaços vazios que permeiam todo o território urbano. 


\section{3- CONTROLE DO USO E OCUPAÇÃO DO SOLO DE CUIABÁ}

O Plano Diretor de 1992 baseou-se em três princípios que também observamos no de 2007. São eles o não-zoneamento, a ocupação do solo com base na infraestrutura disponível e o uso do solo compatível com a vizinhança. Chamado de inovador na época por se diferenciar dos moldes modernistas que instituíam um zoneamento com atividades mais rigidamente condensadas em zonas específicas, esta proposta foi substituída pelo macrozoneamento (Rural e Urbana) e a zona urbana foi subdividida em zonas de interesse de uso, para compatibilizar melhor o interesse da população e do poder público, inclusive com as exceções. Assim mesmo tentando inovar, não se teve como fugir do estabelecimento de algumas Zonas.

O Plano atual continuou com a mesma estrutura, tanto que não foram formulados novos mapas de zoneamento, sendo utilizados os já existentes.

Cuiabá define zoneamento no art. 31 do seu Plano Diretor como:

(...) "o estabelecimento de áreas diferenciadas de adensamento, uso e ocupação do solo, visando dar a cada região melhor utilização em função das diretrizes de crescimento, da mobilidade urbana, das características ambientais e locacionais, objetivando o desenvolvimento sustentável e o bem estar social da comunidade, mediante a observação das condições físicas, ambientais e paisagísticas, de infra-estrutura disponível e usos compatíveis com a vizinhança local".

O zoneamento de Cuiabá, segundo art. 32 do Plano Diretor, utiliza como critérios:

- Os tipos de usos do solo;

- As categorias de Zonas;

- A ocupação do solo urbano;

- A infra-estrutura existente e a implantar;

- As situações já constituídas que representem categorias consolidadas, desde que compatíveis com os elementos estruturadores e integradores pertinentes à vizinhança e ao meio ambiente;

- A vizinhança e;

- O meio ambiente 
Ainda o parágrafo único esclarece que os elementos estruturadores e integradores são a identidade da ocupação, caracterizado pela atividade a que se destinou na época da regularização ou na ocupação.

Os diversos tipos de uso do solo são explicados no art. 33, e levam em consideração o nível impactante, porte, periculosidade, potencial poluidor e incremento da demanda por infra-estrutura como sendo de quatro categorias:

- Inócua: aquelas que não apresentam incomodidade, podendo ser citado como exemplo o uso residencial unifamiliar e aquelas anexas a ela desde que não apresentem área construída maior que 50\% da sua área.

- Compatível: podem e devem integrar-se à vida urbana, desde que se adéqüem à legislação urbana.

- Impactantes: Pelo seu impacto na vizinhança, podem integrar-se à vida urbana comum, adequando-se às exigências de Posturas Municipais, mas que exigem padrões mínimos de infra-estrutura.

- Alto Impacto: Devido ao seu nível impactante, porte, periculosidade, potencial poluidor e incremento da demanda por infraestrutura, necessitam de condições especiais para sua instalação e funcionamento. Esta categoria se subdivide em Alto Impacto Segregável e Alto Impacto não Segregável.

Os diferentes tipos de uso são aplicados em outra categoria de zonas:

- A Zona Urbana de Uso Múltiplo (ZUM), onde não é permitido a implantação de atividades de Alto Impacto Segregável.

- A Zona de Expansão Urbana (ZEX) que corresponde à porção não parcelada dentro do perímetro urbano, e é destinada à ampliação da ocupação urbana.

- As Zonas Urbanas Especiais. Que pelas peculiaridades que apresentam, requerem tratamento diferenciado. Dividem-se em:

a) Zona Residencial Unifamiliar (ZRU).

b) Zonas Centrais (ZC), que se dividem em Área Central (ZAC), Centros Regionais ou Subcentros (ZRC).

c) Zona de Interesse Ambiental (ZIA), subdividida em 1 e 2;

d) Zona de Interesse Histórico (ZIH);

e) Zona de Especial Interesse Social (ZEIS);

f) Zona de Alto Impacto (ZAI);

g) Corredores de Tráfego (CTR); 
h) Zona de Influência de Torre de Controle.

Além do zoneamento, a ocupação do solo é controlada pela quantidade, intensidade e disponibilidade de área a ser construída (art. 38, PDDE, CB), sendo a disponibilidade de infraestrutura, o critério básico para diferenciação dos parâmetros em cada trecho de via (art. 39). Para tanto, foram estabelecidos alguns conceitos fundamentais para que o munícipe saiba quanto de área construída e como poderá construir em seu lote. O Plano apresenta coeficientes, taxas e outros números para regular o uso do solo:

O Padrão geométrico mínimo (PGM) de caixa viária é a largura mínima real ou prevista para cada classe de via. É medido a partir do eixo da via, sendo metade para cada lado. Esta medida define o afastamento frontal mínimo das construções. Os trechos das vias urbanas ficam divididos em (art. 39): inabitável, mínimo, médio, alto, máximo. A Lei apresenta o seguinte quadro para a ocupação do solo urbano:

Quadro 05 - Ocupação do solo urbano de Cuiabá

\begin{tabular}{|c|c|c|}
\hline $\begin{array}{c}\text { PADRÃO DE } \\
\text { INFRA-ESTRUTURA }\end{array}$ & $\begin{array}{l}\text { INFRA-ESTRUTURA } \\
\text { EXISTENTE }\end{array}$ & $\begin{array}{c}\text { LIMITE DE } \\
\text { ADENSAMENTO }\end{array}$ \\
\hline INABITÁVEL & $\begin{array}{l}\text { - Sem infra-estrutura urbana } \\
\text { mínima }\end{array}$ & 0 (zero) \\
\hline MÍNIMO & - Infra-estrutura urbana mínima & 1 (um) \\
\hline MÉDIO & $\begin{array}{l}\text { - Infra-estrutura urbana mínima } \\
\text { - Via pavimentada } \\
\text { - Arborizaçào pública consolidada }\end{array}$ & 2 (dois) \\
\hline ALTO & $\begin{array}{l}\text { - Infra-estrutura urbana mínima } \\
\text { - Via pavimentada } \\
\text { - Arborizaçào pública consolidada } \\
\text { - Padrão geométrico mínimo } \\
\text { ou lagura real de } 18 \text { m (dezoito } \\
\text { metros) } \\
\text { - Acesso direto a via principal ou } \\
\text { estrutural }\end{array}$ & 4 (quatro) \\
\hline MÁXIMO & $\begin{array}{l}\text { - Infra-estrutura urbana mínima } \\
\text { - Via pavimentada } \\
\text { - Arborização pública consolidada } \\
\text { - Padrão geométrico mínimo ou } \\
\text { lagura real de } 24 \text { m (vinte e quatro } \\
\text { metros) } \\
\text { - Acesso direto a via principal ou } \\
\text { estrutural } \\
\text { - Galeria de águas pluviais } \\
\text { - Rede de esgoto } \\
\text { - Hidrantes }\end{array}$ & 6 (seis) \\
\hline
\end{tabular}

Fonte: Plano Diretor de 2007 


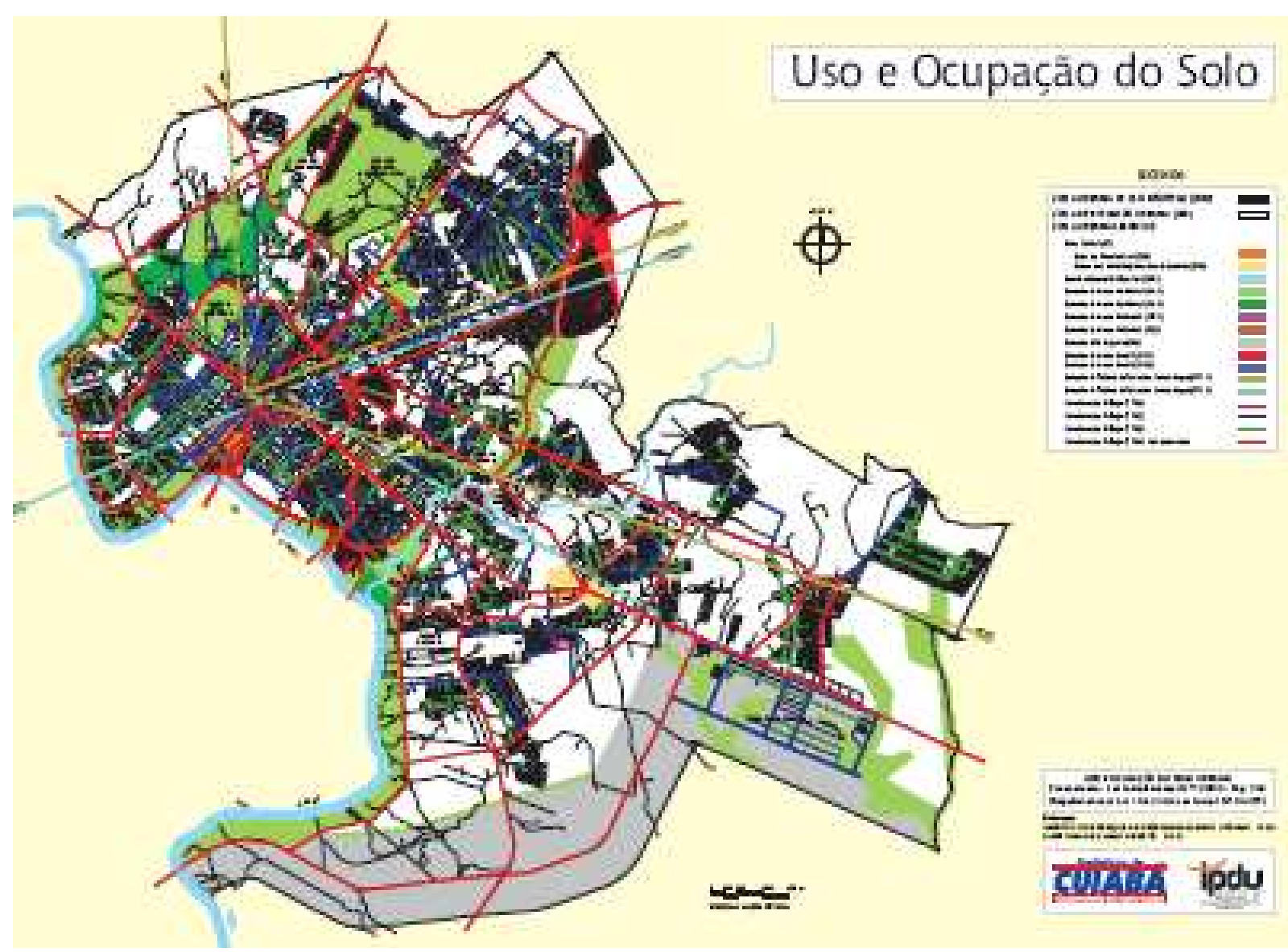

Figura 17 - Uso e Ocupação do Solo de Cuiabá

Fonte - Plano Diretor de Cuiabá de 1992 
Muitos dos instrumentos urbanísticos apresentados pelo Estatuto da Cidade já estavam presentes no Plano Diretor de 1992, e da mesma forma estão no Plano atual. Os instrumentos que proporcionarão o desenvolvimento urbano são:

\section{a) Edificação/Parcelamento Compulsórios IPTU progressivo no tempo}

A Lei específica, ainda não elaborada, poderá exigir que o proprietário do solo urbano promova sua utilização sob pena de aplicação dos mecanismos previstos no Estatuto da Cidade (LEI 10.257/01), ou seja:

- Parcelamento, edificação ou utilização compulsórios;

- Imposto predial e territorial progressivo no tempo;

- Desapropriação com pagamento mediante títulos da dívida pública.

Conforme o art. 56, $\S 1^{\circ}$, esta exigência se dará em áreas onde existe infraestrutura disponível, boa topografia e qualidade ambiental adequada ao adensamento. As áreas deverão estar previstas em lei específica, e poderá inclusive ser diferenciada para cada área dependendo do interesse da municipalidade, podendo atingir imóveis não utilizados, subutilizados e não edificados. Os proprietários deverão ser notificados e a lei determinará o prazo para o devido aproveitamento. O não atendimento incidirá nas penalidades supracitadas.

Depois de notificado para dar um aproveitamento adequado à área, ou seja: parcelamento, edificação ou utilização, o proprietário terá um prazo determinado em lei para a realização. O não-atendimento dará o direito ao município de aplicar o Imposto Predial e Territorial Progressivo no Tempo majorando a alíquota no prazo de cinco anos consecutivos, e permanecerá a alíquota máxima até que se cumpra a obrigação, sendo proibida a anistia relativa à tributação. Decorrido os cinco anos poderá, o município promover a desapropriação do imóvel com pagamento mediante títulos da dívida pública. Embora o município tivesse o prazo de 240 dias para elaborar a lei, esta ainda não foi feita.

Outro problema para a aplicação deste instrumento se deve ao tamanho da área delimitada como perímetro urbano, que é muito grande e cheia de vazios. Assim a disponibilidade de terra é grande, sendo fundamental um critério para que o instrumento seja utilizado de forma justa e proveitosa pelo município.

Detalhes deste instrumento serão definidos em Legislação específica (art. 57).

O art. 64, parágrafo único diz: 
"Todo e qualquer imóvel não edificado com área igual ou superior a $10.000 \mathrm{~m} 2$, fica sujeito aos institutos do Parcelamento, Edificação ou Utilização Compulsórios, do Imposto Predial e Territorial Progressivo, e do direito de Preempção".

Estão sujeitos ainda os imóveis localizados em áreas com infraestrutura e condições ambientais favoráveis, os que se encontrem desocupados, subutilizados ou não-utilizados (art. 56, parágrafo $2^{\circ}$, e art. 90, XXXIV), apesar do prazo para a lei ser elaborada era de 240 dias a partir da aprovação do PDDE (art. 90), mas ainda não foi regulamentada.

Até o presente momento não foi utilizado, mas poderá ser uma ferramenta eficaz para forçar a ocupação de grandes lotes e áreas vazias nas proximidades da área central da cidade, onde se verifica boa infraestrutura urbana.

\section{b) Outorga Onerosa do Direito de Construir}

Já estava previsto no Plano anterior e depende da infraestrutura local, do aproveitamento do solo e do uso na localidade, sendo analisado então caso a caso.

O direito de construir acima do índice urbanístico estipulado pelo coeficiente de aproveitamento mediante contrapartida do proprietário será aplicada nos termos que a lei específica autorizar (art. 65), levando-se em conta a infraestrutura ou o interesse da administração municipal. Como a lei não foi ainda elaborada, tem valido a regra anterior, e o recurso vai para um fundo (FUNDUR) destinado a ações de interesse social.

\section{c) Transferência do Direito de Construir}

É a autorização que o município concede ao proprietário do imóvel urbano, para edificar em outro local, ou alienar mediante escritura pública, o potencial construtivo de determinado lote. Dependerá de uma lei específica que regulará o instrumento, embora o Plano Diretor já adiante as finalidades para a autorização, sendo elas, conforme os incisos do art. 66:

I- promoção, proteção e preservação do patrimônio histórico cultural, natural e ambiental;

II- programas de regularização fundiária, urbanização de áreas ocupadas por população de baixa renda e habitação de interesse social;

III- implantação de equipamentos urbanos e comunitários, e espaços de uso público;

IV- melhoramentos do sistema viário básico; 
V- proteção e preservação dos córregos da região polarizada de envolvidos.

Cuiabá mediante convênio ou consórcio entre os municípios

Da mesma forma que o instrumento anterior já era previsto na legislação e depende da infraestrutura e do uso e ocupação do solo do local onde será exercido e tem sido utilizado para a preservação do patrimônio histórico de Cuiabá.

\section{d) Operação Urbana Consorciadas}

$\mathrm{O}$ art. 67 coloca que será um instrumento para alcançar a transformação urbanística de uma área com a finalidade de melhorias sociais, estruturais, ambientais, e da infraestrutura, com adequação do sistema viário e também para promover habitações de interesse social.

Cada operação deverá ser criada por uma lei própria e o Instituto de Planejamento e Desenvolvimento Urbano de Cuiabá - IPDU é quem deverá coordenar acompanhar e monitorar as operações. Os recursos obtidos pelo poder público serão utilizados apenas na área de intervenção, e a Lei específica para a operação urbana consorciada poderá prever a emissão pelo município de certificados de potencial adicional de construção. Estes serão alienados em leilão ou utilizados diretamente no pagamento das obras e serviços necessários à própria operação (art.71).

As Operações Urbanas Consorciadas terão como finalidade (art. 69):

I-“ implantação de espaços e equipamentos públicos;

II- otimização de áreas envolvidas em intervenções urbanísticas de porte e reciclagem de áreas consideradas subutilizadas;

III- implantação de programas de habitação de interesse social;

IV- ampliação e melhoria do sistema de transporte público coletivo;

V- proteção e recuperação de patrimônio ambiental e cultural;

VI- melhoria e ampliação da infraestrutura e da rede viária;

VII- dinamização de áreas visando à geração de empregos;

VIII- reurbanização e tratamento urbanístico de áreas".

Conforme art. 70, embasado no Estatuto da Cidade, a lei devera conter no mínimo:

I-“definição da área de abrangência e do perímetro da área da intervenção;

II - programas básicos de ocupação da área e de intervenções previstas;

III - estudo prévio de impacto de vizinhança;

IV - programa de atendimento econômico e social para a população diretamente afetada pela operação; 
V - contrapartida a ser exigida dos proprietários, usuários permanentes e investidores privados em função da utilização dos benefícios previstos; VI - forma de controle da operação, obrigatoriamente compartilhada com representação da sociedade civil".

Nas áreas definidas para operações urbanas, o município terá o direito de preempção nos termos da Lei de Gerenciamento Municipal.

\section{e) EIV - Estudo de Impacto de Vizinhança}

Segundo o art. 78 do PDDE, o conteúdo mínimo do Estudo de Impacto de Vizinhança e respectivo Relatório de Impacto de Vizinhança serão os mesmos solicitados pelo Estatuto da Cidade:

O Plano solicita que a elaboração seja em linguagem simples, ilustrados por imagens georreferenciadas, por mapas, cartas, quadros, gráficos etc. para sua perfeita compreensão.

Os estudos deverão ser apresentados à Secretaria de Meio Ambiente (SMADES) para abertura do processo e para os devidos trâmites legais, seguido da aprovação pelo Conselho Municipal de Desenvolvimento Urbano - CMDU. Deverá ser dada ampla publicidade aos documentos.

O EIV e o Relatório de Impacto de Vizinhança deverão ser elaborados, conforme o art. 77, para as atividades e empreendimentos realizados por agentes públicos e privados, da subcategoria ALTA IMPACTO NÃO SEGREGÁVEL, e o instrumento tem sido cobrado nos empreendimentos enquadrados na lei.

\section{f) Direito de Preempção}

O Plano Diretor define no parágrafo do art. 64 que toda a área com mais de $10.000 \mathrm{~m}^{2}$ (dez mil metros quadrados), e as que a lei específica autorizar, estará sujeita ao direito de preempção do poder público municipal.

Segundo o art. 61, se aplicará nas áreas definidas em lei para programas de regularização fundiária, habitação, implantação de equipamentos urbanos, unidades de conservação e outros que a lei definir.

No município de Cuiabá não será de tanta utilidade, tendo em vista que existem muitas áreas vazias em praticamente todos os bairros da cidade. Cabe ainda considerar que o Código Civil permite ao município realizar a desapropriação da área com 
pagamento segundo o valor de mercado quando se necessitar de área para a implantação de benfeitorias, e dificilmente o município possuirá recursos para adquirir terras para futura utilização.

\section{g) ZEIS}

Atualmente o assunto é tratado na Lei Complementar 108 de 23/12/03, mas segundo o Plano Diretor deverá ser elaborado o Plano de Habitação e a questão das ZEIS deverá ser assunto de legislação específica a ser elaborada.

No mapa de Uso do Solo, aparecem como ZIS - Zonas de Interesse Social e correspondem às ocupações de baixa renda já existentes. Nestas localidades as leis urbanísticas puderam ser flexibilizadas para a regularização fundiária, mas pode se constatar que não houve a demarcação de novas áreas, inclusive áreas vazias para instalação de habitações de interesse social, limitando que o instrumento seja de pronto utilizado e que direcione o desenvolvimento urbano.

A partir da revisão, espera-se que este mapa sofra alterações por conta dos estudos referentes à habitação que estão em andamento.

O Plano Diretor de Cuiabá, no art. 37, estabelece que a prefeitura deverá encaminhar anualmente, anexo à proposta de orçamento, o plano de intervenção nas ZEIS, e a indicação dos recursos que consumirão. Como o Plano de Habitação ainda não está pronto, ainda não existem estas ações.

\section{h) Da Conseção de Uso Especial para Fim de Moradia}

No art. 55, $\S 2^{\circ}$ o PDDE diz que nos casos de programas e projetos habitacionais de interesse social, desenvolvidos por órgãos ou entidades da Administração Pública com atuação específica nessa área, a concessão do direito real de uso de imóveis públicos poderá ser contratada coletivamente. Este instrumento está disponível independente de regulamentação, pois existe lei de âmbito federal regulando o assunto, dependendo apenas da vontade (ação) municipal para resolver os casos existentes.

\section{4- AÇÕES REFERENTES AO USO E À OCUPAÇÃO DO SOLO EM CUIABÁ}

A entrada em vigor do Plano Diretor Estratégico de Cuiabá acabou trazendo algumas incumbências a mais para os órgãos da administração pública municipal. Uma 
série de Planos setoriais e leis, para complementá-lo, deveriam estar prontas, porém, dois anos depois, os planos, projetos e a revisão da legislação ainda não estão concluídos e muitos nem sequer iniciados os estudos. Mas existe uma movimentação nesta direção em alguns setores, especialmente no IPDU.

Como é sua principal atribuição, o cuidado com o planejamento e o desenvolvimento urbano, o IPDU vem elaborando uma série de estudos, e trabalhos para melhorar de forma geral a cidade. Entre as atividades desenvolvidas atualmente no IPDU, destacamos as seguintes:

a) O IPDU está coordenando uma equipe de servidores de diversas formações e vindos de diversas secretarias que estão se dedicando à uma profunda revisão de toda a legislação urbanística da cidade, o que deverá implicar em várias alterações na Lei de Zoneamento, Uso e Ocupação do Solo. O intuito é de atualizar todas as normas que influenciem nas questões urbanísticas para que fiquem em conformidade com os princípios que norteiam o Plano Diretor Municipal.

b) Está sendo rediscutida a delimitação dos distritos municipais para que fiquem em conformidade com a configuração da cidade atual. Hoje, existem distritos que se localizam dentro do perímetro urbano, como o do Coxipó, e existem aglomerações rurais que merecem ser transformadas em sedes de distrito, como é o caso do Iguaçu, e o de Nova Esperança/Pequiseiro, que poderão ser criados.

c) O corpo técnico do IPDU tem trabalhado na hierarquização das vias, tendo em vista a modificação de todo o sistema de transporte coletivo para acomodar ônibus bi articulados que se deslocarão em corredores exclusivos para ônibus urbanos. Assim se definirá um novo sistema de transporte público, com a construção de novos terminais, novos corredores e novos itinerários (conforme plano descrito adiante).

d) A prefeitura trabalha na implantação do projeto de revitalização do Córrego Gumitá. Trata-se de um parque linear ao longo do Córrego, com a recuperação das margens, a remoção das casas que ocupavam as áreas de preservação (e estavam inclusive sujeitas às enchentes) e o saneamento ambiental para a região de entorno.

e) Está sendo elaborado o projeto de revitalização do centro histórico, pretendendo-se especialmente a revisão das áreas de estacionamento ao longo das calçadas, o rebaixamento da fiação elétrica (que será subterrânea), o redimensionamento de vias e das calçadas e proporcionar acessibilidade em toda a área.

f) Continua a busca por viabilizar o chamado "complexo tempos modernos" que compreende a construção de terminal de ônibus integrado a um shopping popular com a 
viabilização de outros serviços, e a integração com a estrutura de concreto que abrigava o antigo cais do porto (onde se pretende a construção de restaurantes e de mirante para observação do Rio Cuiabá).

Podemos então concluir que as duas cidades estabeleceram zoneamento, mesmo que Cuiabá procure a negação deste, não abriu mão de instituir algumas Zonas. $\mathrm{O}$ zoneamento proposto tanto por Cuiabá como por Várzea Grande atendem de modo geral às necessidades da população ao permitir uma diversidade de usos compatíveis na mesma localidade facilitando o dia a dia do munícipe, e delimitando as áreas frágeis ambientalmente ou estabelecendo regras diferenciadas para áreas especiais, como é o caso das centralidades dos bairros e do centro histórico de Cuiabá.

Porém, Várzea Grande deverá se estruturar para poder conter a ocupação em áreas de proteção ambiental e aplicar as regras urbanísticas instituídas. Cuiabá, que já está mais estruturada quanto a estas questões, necessitará, assim como Várzea Grande de fazer as leis necessárias para a aplicação dos instrumentos urbanísticos de modo transparente e que permita o acompanhamento das ações e o controle dos recursos auferidos pela aplicação dos instrumentos de desenvolvimento urbano instituídos no Plano Diretor.

É certo, contudo, que alguns instrumentos como o direito de preempção não serão tão utilizados a curto ou médio prazo, pelas características das cidades, mas outros como o IPTU Progressivo serão fundamentais para a ocupação de vazios urbanos, evitando a especulação imobiliária das áreas próximas às regiões centrais das cidades.

Embora com diferenças na concepção do ordenamento territorial, os municípios não instituíram zoneamento conflitante, e devido ao tamanho dos perímetros urbanos, não terão dificuldades de realizar ações que visem proporcionar habitação às famílias de baixa renda. 


\section{CAPÍTULO 06- HABITAÇÃO, ACESSO À TERRA URBANIZADA E REGULARIZAÇÃO FUNDIÁRIA}

Nos anos 1960, o Governo Federal buscou através dos Planos Nacionais de Desenvolvimento (PNDs) a ocupação dos imensos espaços vazios que caracterizavam as terras Centrais brasileiras e da Amazônia. Para isso, se valeu de uma série de ações e incentivos, podendo ser citadas como exemplos a construção das rodovias Cuiabá Porto Velho (BR-364) e Cuiabá - Santarém (BR-163), o Programa de Desenvolvimento dos Cerrados e incentivos fiscais para as empresas que se estabeleciam na localidade. Cuiabá, assim como também Várzea Grande, sofreu os impactos do Programa de Integração Nacional e da política de ocupação da Amazônia. Assim os programas: Polamazônia, Polocentro, Prodepan e Finam (além de outros), foram responsáveis pela intensificação da ocupação nas décadas de 1970 e 1980.

Por conta dos incentivos e das obras, houve nesta época um intenso fluxo migratório para Cuiabá, atingindo também Várzea Grande, e resultou numa taxa média de $15 \%$ ao ano de crescimento populacional, declinando somente na década de 1990, com 6,7\% ao ano em 1997 (IBGE, 2006).

A questão fundiária é uma grande preocupação dos dois municípios. A falta de moradia nas décadas de 1970, 1980 e 1990 fez com que áreas desocupadas das cidades fossem ocupadas por pessoas que não conseguiam comprar um lote ou uma casa, e acabavam vendo nas imensas áreas vazias da cidade uma opção para fixar suas residências. O processo de "grilagem” de lotes em Cuiabá e Várzea Grande foram bem organizados neste período, e consistia na organização das famílias sem moradias que limpavam a área, faziam o arruamento, demarcavam os lotes mais ou menos padronizados e providenciavam as ligações, clandestinas ou não de água (que geralmente, no primeiro momento era de poço) e de luz. Os grupos geralmente eram grandes e adquiriam força, sendo comum ter políticos ao lado das lideranças locais dando apoio à ocupação e providenciando a infraestrutura mínima como a rede de água potável, a rede elétrica e uma linha de transporte coletivo. A ocupação não se deu apenas em áreas privadas, mas também públicas e de proteção ambiental. Em Várzea Grande e também em localidades mais distantes de Cuiabá, muitos loteamentos que na década de 1970 e 1980 surgiram em locais periféricos ou com problemas ambientais, e sem nenhuma infraestrutura (possuíam geralmente só o arruamento de terra), foram parcialmente vendidos e posteriormente tiveram os lotes invadidos. O preço da terra - 
muito barato nestes locais - não encorajou os proprietários a gastar com custas processuais para reavê-los. Desta forma, os posseiros não viam a documentação da sua moradia como algo prioritário, tendo em vista as demais necessidades, mesmo sendo a regularização considerada algo importante, desejável e fator de valorização do imóvel.

A comercialização de habitações não regulares é comum para quem não possui recursos e nem condições para adquirir sua moradia no mercado formal, e não é difícil vender ou comprar imóveis com problemas na documentação ou mesmo sem documentação. Desta forma (através da posse) surgiram muitos dos bairros de Cuiabá e Várzea Grande e a compra e venda destes imóveis sem as formalidades da escritura pública se tornou comum entre a população carente destas localidades. Atualmente, com o adensamento, a melhoria dos serviços e da infraestrutura urbana de modo geral na cidade, e conseqüentemente a valorização da terra, cada vez menos se tem notícias de novos "grilos" como se via antigamente. A população carente tem a necessidade de buscar outra maneira de conseguir habitação. Os programas habitacionais do Governo Federal e do Estadual têm mitigado sensivelmente a situação, porém a questão da regularização fundiária de várias áreas, inclusive áreas públicas, ainda precisa ser encarada com maior vigor, pois cada vez mais, a população exige seu direito de ter a escritura da sua casa, consumando o status de proprietário.

\section{1- HABITAÇÃO, ACESSO À TERRA URBANIZADA E REGULARIZAÇÃO FUNDIÁRIA EM V. GRANDE}

Várzea Grande embasou as diretrizes para a habitação nas leituras comunitárias e técnica. Destas leituras pode-se identificar a cidade real e a cidade legal. Segundo O Volume II - Leitura Técnica - elaborado pela VERTRAG, 2007, os principais desafios relativos às questões habitacionais se encontram na Macrozona Urbana (que abriga $98 \%$ da população, com taxas de crescimento a 3,48\% ao ano - IBGE 2000). Nela a cidade real abriga os diversos usos consolidados, entre eles o mais predominante é o residencial e coincide com o sítio loteado especialmente a partir da década de 1960, quando se intensifica o crescimento demográfico. As áreas mais consolidadas e adensadas são as localizadas no Distrito de Cristo Rei (onde os diversos tipos de usos encontram-se bem mesclados), as situadas à nordeste da Avenida Gov. Júlio Campos, à oeste da Avenida Leôncio de Miranda, à leste das Avenidas Brigadeiro Eduardo Gomes e nas imediações da Av. Alzira Santana. Nas demais áreas, a densidade é menor, com 
existência de grandes vazios urbanos. Nas periferias está situada a maioria dos assentamentos irregulares e dos conjuntos habitacionais populares.

Os problemas fundiários e de habitação de interesse social estão intimamente ligados às áreas de fragilidade ambiental, de risco de acidentes naturais (enchentes), especulação imobiliária e a consolidação de uma periferia carente.

A Secretaria de Viação Obras e Urbanismo constatou no ano de 2006 a existência de 43 ocupações irregulares, sendo consideradas irregulares as terras "griladas", os parcelamentos clandestinos, e os irregulares. Estas ocupações se encontram em todas as áreas da cidade, mas principalmente, e em maior número, na periferia. Outra prática irregular e que merece destaque é o aterramento de lagoas para posterior ocupação, como aconteceu na Lagoa do Jacaré e Lagoa da FEB e a ocupação das faixas de proteção dos córregos, que se verifica de forma generalizada dentro do perímetro urbano.

Desta forma observa-se que a questão habitacional não tem sido tratada, ao longo do tempo, de forma articulada com o planejamento territorial e com a gestão fundiária e fiscal.

A questão não é tratada de forma articulada nem mesmo dentro da prefeitura, onde as atividades estão pulverizadas em diversas secretarias.

"Não se observou o efetivo inter-relacionamento entre a Secretaria Municipal de Promoção e Assistência Social, responsável pelo cadastro e acompanhamento dos programas habitacionais; a Secretaria Municipal de Planejamento, responsável pelo planejamento territorial; a Secretaria Municipal de Viação, Obras e Urbanismo, responsável pela aprovação de projetos; e da Procuradoria Patrimonial, responsável pela regularização fundiária. Na realidade, isso ocorre devido à inexistência de um órgão municipal inteiramente responsável pela questão habitacional, havendo a segmentação observada". (VERTRAG VOL II, pág. 221)

A questão da habitação segundo a VERTRAG, 2007, "tem sido historicamente enfrentada a partir da implantação de programas de lotes urbanizados e construção de conjuntos residenciais, financiados em parceria com os outros entes da federação.

Atendimento Habitacional para Pessoas Inscritas - Várzea Grande - 2003/2005. 
Quadro 06 - Programas habitacionais

\begin{tabular}{|l|l|l|l|l|}
\hline \multirow{2}{*}{ ROGRAMAS } & \multicolumn{4}{|l|}{ ATENDIMENTOS } \\
\cline { 2 - 5 } & 2003 & 2004 & 2005 & TOTAL \\
\hline $\begin{array}{l}\text { Programa de Arredamento Residencial } \\
\text { PAR - CAIXA Econômica Federal }\end{array}$ & 555 & 494 & 391 & 1.440 \\
\hline $\begin{array}{l}\text { Programa MEU LAR } \\
\text { Governo de Mato Grosso }\end{array}$ & 100 & 100 & 366 & 566 \\
\hline TOTAL & 655 & 594 & 757 & 2.006 \\
\hline
\end{tabular}

Fonte: Secretaria Municipal de Promoção e Assistência Social - 2006.

Assim a prefeitura se encontra despreparada para a execução de políticas habitacionais. Apesar dos instrumentos urbanísticos que o antigo Plano Diretor já oferecia eles nunca foram regulamentados, porque não houve uma discussão de forma integrada para articular as ações no âmbito da: regularização fundiária, déficit habitacional, tributação, planejamento no âmbito local e do Aglomerado Urbano, priorização de ações no tempo, e a regulamentação de instrumentos de regularização fundiária.

$\mathrm{Na}$ comparação da densidade demográfica da cidade com a densidade construtiva e a capacidade de infraestrutura urbana, a leitura técnica demonstrou que existem contradições quanto à ocupação do solo urbano em Várzea Grande. A região mais densa e populosa é a que apresenta as maiores fragilidades ambientais, ou seja: a região do Cristo Rei, onde $49 \%$ da população da cidade ocupa $20 \%$ da área total do perímetro urbano. (VERTRAG - 2007)

Foi verificado que $49 \%$ da população residem em uma área equivalente a $20 \%$ do perímetro urbano referente à porção que vai do centro até o extremo leste (beira do rio Cuiabá), apesar do contínuo processo de expansão da cidade em direção às periferias.

A localização da população no perímetro urbano, conforme VERTRAG - 2007 contrapõe-se à localização dos loteamentos legalmente aprovados, e que não foram ocupados ou sequer implantados (mais distantes do centro e desprovidos de serviços nas imediações, além do custo da terra ser alto para a maioria da população). Também foi observada a implantação de vários loteamentos fora do perímetro urbano, encarecendo o fornecimento de serviços e de infraestrutura, causando vazios urbanos.

Desta forma, os custos dos serviços e da infraestrutura urbana tornam-se caros para o município, e para os munícipes (vide quadro demonstrativo da renda). 
Agravando ainda a situação, a VERTRAG - 2007 pág. 216, completa com as considerações a respeito da instituição e da legislação:

(i) "Existência de legislação de uso e ocupação do solo inaplicável e imprecisa

(ii) Falta de fiscalização e controle do processo de uso e ocupação do solo,

(iii) Inexistência de planejamento territorial com definição de programas e projetos prioritários para execução da política de gestão territorial urbana;

(iv) Falta ou inexistência de técnicos, no quadro de servidores municipais, capazes de implementar tal política,

(v) A política fiscal praticada não tem como prioridade a recuperação para a coletividade da valorização imobiliária de propriedades particulares beneficiadas com os investimentos públicos em urbanização".

Após apurar o difícil panorama acima descrito, o atual Plano Diretor buscou o enfrentamento da questão, atrelando o controle urbanístico com a a promoção de habitação (especialmente a de interesse social) e regularização fundiária e infraestrutura urbana.

Assim, para Várzea Grande, a política de desenvolvimento socioespacial inclui a promoção da habitação de interesse social, a regularização fundiária e a implantação de infraestrutura nas áreas de ocupação já consolidadas, reconhecendo o direito de todos os cidadãos de ter acesso à terra urbanizada e a condições dignas da habitação (art. 29, inc. IV e V). Da mesma forma compreende que não conseguirá sanar seu déficit habitacional - estimado em dez mil unidades aproximadamente - sem um plano para habitação e sem a articulação com as políticas habitacionais estaduais e federais. Reconhece também a completa falta de estrutura do município para as ações voltadas a questão habitacional, tanto que consta do art. 29, inc. VIII, a criação da Agência Municipal de Habitação, a instituição do Conselho e do Fundo Municipal de Habitação, e do Plano Municipal de Habitação. A articulação com outros níveis de governo está prevista no PDP de Várzea Grande no art. $8^{\circ}$, inc. I, de forma bem ampla e genérica nos seguintes termos:

“(...) aumentar a eficácia da ação governamental, promovendo a integração e cooperação com outros municípios, com os governos Estaduais e Federais e com a iniciativa privada no processo de planejamento e gestão das questões de interesse comum;" 
A garantia de transparência e simplificação na tramitação dos processos e, por fim, propõe que o ordenamento espacial se fundamente na cidade real, que seja contido a expansão do perímetro urbano, e que a fiscalização seja atuante, evitando a ocupação das áreas impróprias para moradia, conforme os objetivos da função social da cidade e da propriedade.

O Plano Diretor autoriza no art. 121 a constituição do Fundo Municipal de Desenvolvimento Urbano - FMDU - criado por lei própria, para prestar suporte financeiro ao desenvolvimento de projetos relacionados a:

I. Regularização fundiária;

II. Execução de programas e projetos habitacionais de interesse social;

III. Ordenamento e direcionamento da expansão urbana;

IV. Implantação de equipamentos urbanos e comunitários;

V. Criação de espaços públicos de lazer e áreas verdes;

VI. Criação de unidades de conservação ou proteção de outras áreas de interesse ambiental;

VII. Proteção de áreas de interesse histórico, cultural ou paisagístico.

O órgão gestor será o Conselho da Cidade (art. 112, inc. VIII) e, como versa o art. 122, os recursos que comporão o FMDU virão de:

I. Dotações orçamentárias específicas do Município, preferencialmente com a utilização do acréscimo da receita decorrente da implementação do IPTU progressivo no tempo;

II. Contribuições, doações e transferências dos setores públicos e privados;

III. Produtos de operações de crédito celebradas com organizações nacionais e internacionais;

IV. Rendas procedentes da aplicação financeira dos seus próprios recursos;

V. Receitas provenientes da aplicação da outorga onerosa do direito de construir e de outros instrumentos urbanísticos previstos na presente Lei;

VI. Receitas decorrentes da cobrança de multas por infração à legislação urbanística.

O Conselho da Cidade será um importante elemento de fiscalização e controle da implantação das políticas e ações voltadas para a habitação e para o desenvolvimento e controle urbano do município de Várzea Grande.

Quanto às Zonas Especiais de Interesse Sociais, o Plano Diretor estabelece que elas sejam delimitadas pelo poder público municipal que se sobrepõem ao Zoneamento 
Urbano. Nelas é elaborado um plano urbanístico apropriado, com a participação da população interessada, que podem definir padrões de uso e ocupação do solo diferenciados da legislação corrente. E podem ser criadas apenas em casos que a lei específica autorizar, postergando então a efetividade da criação das leis que delimitam e instituem as ZEIS em Várzea Grande. Mesmo porque as tabelas urbanísticas não determinam critérios muito favoráveis, nem muito diferenciados para as ZEIS. Vejamos alguns dados da tabela III - Parâmetros de Uso e Ocupação do solo 1, do PDP:

Tabela 04 - Parâmetros de uso e ocupação do solo de Várzea Grande I

\begin{tabular}{|c|c|c|c|c|c|c|}
\hline \multirow[t]{2}{*}{ Zona } & \multirow[t]{2}{*}{$\begin{array}{l}\text { Característica da } \\
\text { Área }\end{array}$} & \multicolumn{2}{|l|}{ Lote } & \multicolumn{3}{|c|}{$\begin{array}{ll}\text { Coeficiente } & \text { de } \\
\text { Aproveitamento } & \end{array}$} \\
\hline & & $\begin{array}{l}\text { Fração } \\
\text { mínima } \\
\left(\mathbf{m}^{2}\right)\end{array}$ & $\begin{array}{l}\text { Frente } \\
\text { mínima } \\
(\mathrm{m})\end{array}$ & mínimo & básico & Extra \\
\hline \multirow[t]{4}{*}{ ZR } & $\begin{array}{l}\text { Novos parcelamentos } \\
\text { na Área de Ocupação } \\
\text { Consolidada - Setor } 1\end{array}$ & 360 & 12 & - & 0,8 & 1 \\
\hline & $\begin{array}{l}\text { Novos parcelamentos } \\
\text { na Área de Ocupação } \\
\text { Consolidada - Setor }\end{array}$ & 250 & 10 & 0,2 & 1 & 2,5 \\
\hline & $\begin{array}{l}\text { Novos parcelamentos } \\
\text { inseridos nas demais } \\
\text { áreas da zona - setor } 3 \\
\end{array}$ & 360 & 12 & - & 1 & - \\
\hline & Regularização fundiária & 180 & 10 & - & 0,4 & 1 \\
\hline \multirow[t]{4}{*}{ ZUM } & $\begin{array}{l}\text { Novos parcelamentos } \\
\text { inseridos na Área de } \\
\text { Ocupação Controlada }\end{array}$ & 360 & 12 & - & 0,8 & 1 \\
\hline & $\begin{array}{l}\text { Novos parcelamentos } \\
\text { inseridos na Área de } \\
\text { Intensificação } \\
\text { Ocupação Setor } 5\end{array}$ & 360 & 12 & 0,2 & 1 & 2,5 \\
\hline & $\begin{array}{l}\text { Novos parcelamentos } \\
\text { inseridos nas demais } \\
\text { áreas da zona setor } 6\end{array}$ & 360 & 12 & - & 1 & - \\
\hline & $\begin{array}{l}\text { Regularização de lotes } \\
\text { ou frações de lotes } \\
\text { existentes e edificados }\end{array}$ & 180 & 10 & - & 0,4 & 1 \\
\hline
\end{tabular}

Fonte: Plano Diretor de Várzea Grande de 2007.

Podemos observar que os coeficientes de aproveitamento dos lotes, tanto da Zona Residencial como da Zona de Uso Misto, são baixos, e mesmo nas áreas onde se deseja o adensamento, o coeficiente básico 1 não permite muita construção. Da mesma forma o tamanho dos lotes, onde a fração mínima é 250, na área de adensamento, não propicia a construção de residências para família com pouca renda - até 3 salários mínimos - e mesmo para famílias com renda acima disto - 3 a 10 salários - torna-se 
difícil o investimento por parte da iniciativa privada, mesmo com o preço da terra bastante favorável, o custo da infraestrutura seria grande. Na Área para ocupação controlada, com lotes mínimos de $350 \mathrm{~m}^{2}$, apenas loteamentos para a classe média e alta seria viável, mesmo assim, muitos conjuntos habitacionais e atualmente vários conjuntos referentes ao Programas de Arrendamento Habitacional da Caixa Econômica Federal tem sido construídos, em terrenos menores que o mínimo.

E também da Tabela IV, com os parâmetros de Uso e Ocupação do Solo.

Tabela 05 - Parâmetros de uso e ocupação do solo de Várzea Grande II

\begin{tabular}{|c|c|c|c|c|c|c|c|}
\hline \multirow[t]{2}{*}{ Zona } & \multirow{2}{*}{$\begin{array}{l}\text { Característi } \\
\text { ca da Área }\end{array}$} & \multirow{2}{*}{$\begin{array}{l}\text { Taxa de } \\
\text { Ocupação } \\
\text { Máxima }\end{array}$} & \multirow{2}{*}{$\begin{array}{l}\text { Taxa de } \\
\text { Permeab. } \\
\text { Mínima } \\
(\%)\end{array}$} & \multicolumn{2}{|c|}{ Recuos Mínimos } & \multirow{2}{*}{$\begin{array}{l}\text { Número } \\
\text { Máximo } \\
\text { de } \\
\text { pavimento } \\
\text { s } \\
\end{array}$} & \multirow{2}{*}{$\begin{array}{l}\text { Densidad } \\
\text { e máxima } \\
\text { do lote } \\
\text { (hab/há) }\end{array}$} \\
\hline & & & & $\begin{array}{l}\text { Front } \\
\text { al } \\
(\mathbf{m})\end{array}$ & $\begin{array}{l}\text { Demais } \\
\text { Divisas com } \\
\text { abertura (m) }\end{array}$ & & \\
\hline \multirow[t]{4}{*}{ ZR } & $\begin{array}{l}\text { Novos } \\
\text { parcelament } \\
\text { os na Área } \\
\text { de Ocupação } \\
\text { Consolidada } \\
\text { - Setor 1 }\end{array}$ & 50 & 30 & $\begin{array}{l}3,00 \\
(4) \\
5,00 \\
(5)\end{array}$ & 1,50 & 2 & 200 \\
\hline & $\begin{array}{l}\text { Novos } \\
\text { parcelament } \\
\text { os na Área } \\
\text { de Ocupação } \\
\text { Consolidada } \\
\text { - Setor }\end{array}$ & 62,5 & 20 & $\begin{array}{l}3,00 \\
(4) \\
5,00 \\
(5)\end{array}$ & $\begin{array}{l}1,50 \text { para o } \\
\text { pavimento } \\
\text { térreo e } \mathrm{h} / 6 \text { a } \\
\text { partir do } 2^{\circ} \\
\text { pav. } \\
\text { Respeitando o } \\
\text { mim. de } 1,50\end{array}$ & 4 & 600 \\
\hline & $\begin{array}{l}\text { Novos } \\
\text { parcelament } \\
\text { os inseridos } \\
\text { nas demais } \\
\text { áreas da } \\
\text { zona - setor } \\
3\end{array}$ & 50 & 30 & $\begin{array}{l}3,00 \\
(4) \\
5,00 \\
(5)\end{array}$ & 1,5 & 2 & 356 \\
\hline & $\begin{array}{l}\text { Regularizaçã } \\
\text { o fundiária }\end{array}$ & 50 & 30 & $\begin{array}{l}3,00 \\
(4) \\
5,00 \\
(5)\end{array}$ & 1,5 & 2 & 156 \\
\hline \multirow[t]{2}{*}{ ZUM } & $\begin{array}{l}\text { Novos } \\
\text { parcelament } \\
\text { os inseridos } \\
\text { na Área de } \\
\text { Ocupação } \\
\text { Controlada }\end{array}$ & 50 & 30 & $\begin{array}{l}3,00 \\
(4) \\
5,00 \\
(5)\end{array}$ & 1,5 & 2 & 200 \\
\hline & $\begin{array}{l}\text { Novos } \\
\text { parcelament } \\
\text { os inseridos } \\
\text { na Área de } \\
\text { Intensificaçã } \\
\text { o da }\end{array}$ & 50 & 20 & $\begin{array}{l}3,00 \\
(4) \\
5,00 \\
(5)\end{array}$ & $\begin{array}{l}1,50 \text { para o } \\
\text { pavimento } \\
\text { térreo e } \mathrm{h} / 6 \mathrm{a} \\
\text { partir do } 2^{\circ} \\
\text { pav. } \\
\text { Respeitando o }\end{array}$ & 6 & 800 \\
\hline
\end{tabular}




\begin{tabular}{|c|c|c|c|c|c|c|}
\hline $\begin{array}{l}\text { Ocupação } \\
\text { Setor } 5\end{array}$ & & & & mim. de 1,50 & & \\
\hline $\begin{array}{l}\text { Novos } \\
\text { parcelament } \\
\text { os inseridos } \\
\text { nas demais } \\
\text { áreas da } \\
\text { zona setor } 6\end{array}$ & 50 & 30 & $\begin{array}{l}3,00 \\
(4) \\
5,00 \\
(5)\end{array}$ & $\begin{array}{l}1,50 \text { para o } \\
\text { pavimento } \\
\text { térreo e } \mathrm{h} / 6 \text { a } \\
\text { partir do } 2^{\circ} \\
\text { pav. } \\
\text { Respeitando o } \\
\text { mim. de } 1,50\end{array}$ & 4 & 600 \\
\hline $\begin{array}{l}\text { Regularizaçã } \\
\text { o de lotes ou } \\
\text { frações de } \\
\text { lotes } \\
\text { existentes e } \\
\text { edificados } \\
\text { (6) }\end{array}$ & 50 & 30 & $\begin{array}{l}3,00 \\
(4) \\
5,00 \\
(5)\end{array}$ & 1,5 & 2 & 156 \\
\hline
\end{tabular}

(4) Recuo mínimo para lotes com frente para vias locais.

(5) Recuo mínimo para lotes com frente para as demais vias.

(7) Fórmula para cálculo da densidade máxima do lote:

Densidade máxima $=\mathrm{Hab}$ (número)

Área (ha)

Onde:

Hab = número de habitantes residentes por edificação. Para cada habitação unifamiliar considerar 3,3 habitantes por residência. Para comércio, serviço e indústria

considerar 1 (um) habitante para cada $60,00 \mathrm{~m}^{2}$ de área construída.

Área $=$ medida em hectares (ha).

Fonte: Plano Diretor de Várzea Grande de 2007.

Da mesma forma, as taxas de ocupação são bem pequenas para os lotes, variando de $50 \%$ a $60 \%$, o que obriga a construção em dois pavimentos, aumentando o custo da estrutura das habitações.

Para as vias locais, as dimensões mínimas são:

- Para a caixa da via, $13 \mathrm{~m}$;

- Para a caixa de rolamento, $9 \mathrm{~m}$;

- Faixa de circulação mínima, 3,3m;

- Faixa para estacionamento mínimo, 2,4;

- Passeio mínimo, $2 \mathrm{~m}$.

Não existe diferenciação de parâmetros urbanísticos para as áreas já demarcadas como ZEIS no mapa de Zoneamento, assim tanto as caixas viárias como os demais coeficientes e taxas, são os mesmos para as áreas onde se inserem. Desta forma, fica sem sentido o estabelecimento de ZEIS se não existe um tratamento diferenciado para a região, ficando cada caso dependendo de um processo de elaboração de Lei, que pode ser demorado e burocrático para se viabilizar. 
O Plano não estabelece metas para o enfrentamento da questão habitacional, talvez porque não se conheça ainda qual o tamanho real do problema, assim a elaboração do Plano Municipal de Habitação e a estruturação da Agência de Habitação para colocá-lo em prática é questão decisiva para viabilizar os objetivos do plano quanto à habitação. Como estratégia, existe a previsão dos instrumentos, mas muitos não são autoaplicáveis, dificultando a ação imediata (vide as considerações sobre os instrumentos urbanísticos acima).

O Plano estabeleceu boa parcela do território para as ZEIS, quer seja instituindoas diretamente no zoneamento urbano, quer estabelecidas de forma indireta, através da sobreposição às demais Áreas, de forma que todo o perímetro urbano poderá abrigar uma ZEI.

O Plano não entra em maiores detalhes, deixando o detalhamento para o Plano Municipal de Habitação, que terá entre outras atribuições, a definição do déficit habitacional d município e o levantamento do quantitativo de terrenos públicos e privados que são propícios para a construção de moradias de interesse social.

\section{2- AÇÕES PARA A HABITAÇÃO, ACESSO À TERRA URBANIZADA E REGULARIZAÇÃO FUNDIÁRIA EM VÁRZEA GRANDE}

No município de Várzea Grande o acesso à terra urbanizada tem sido um problema crônico. Não se pode dizer que a população tem dificuldade em conseguir um lote, mas um lote urbanizado, e principalmente um lote legalizado, é diferente de um lote qualquer de terra e isso é realmente difícil para a população várzeagrandense. Quase todas as localidades sofrem com a falta constante de água, até mesmo o centro da cidade reclama do problema, e a falta de rede de esgoto agrava muito a situação do saneamento da cidade. Nos bairros mais carentes e periféricos, as ruas não são pavimentadas e em certas épocas do ano (época das chuvas principalmente) ficam intransitáveis, e geralmente os munícipes caminham muito para ter acesso ao transporte coletivo e a equipamentos comunitários como escolas, creches e postos de saúde. Sem contar as grandes distâncias para se chegar ao centro (ou centralidade mais próxima) e a questão da titularidade.

O déficit habitacional do município estava entorno de dez mil unidades em 2005, e o problema da regularização vem desafiando o poder municipal a agir. Por outro lado, a questão sempre foi tratada de forma secundária tanto na Secretaria de Obras, local 
onde com a atribuição de cuidar da questão, como pelas demais Secretarias que por outros motivos se viam envolvidas na questão habitacional e fundiária. A habitação, assim como o planejamento físico territorial referente ao município sempre foram tratados de forma secundária tanto pela Secretaria de Obras, como pelas outras Secretarias que acabaram envolvidas no processo, como o caso da Secretaria de Planejamento que só fazia o planejamento financeiro e recebeu repentinamente a obrigação de fazer o planejamento urbano do município contando apenas com um técnico e nenhuma estrutura nem experiência. Visto que toda a memória, os projetos e a pouca - mas não menos importante - experiência das questões urbanísticas estavam na Secretaria de Obras. Desta forma a criação deste Órgão que segundo comentário geral seria uma Autarquia denominada Agência de Habitação, cuidaria não apenas destas questões, mas do planejamento físico-territorial da cidade, e seria fundamental para a transformação do município, que é considerado pelos munícipes (segundo a leitura comunitária) uma cidade "feia" e pelos técnicos "sem identidade".

Por força do Plano Diretor, e pela urgência de estruturação do setor, Várzea Grande está se dedicando à estruturação da sua Agência de Habitação, que até outubro de 2009 ainda não estava operando. Segundo a técnica da Secretaria de Planejamento, arquiteta Maria Lúcia Lacerda, este órgão terá a função de tratar os assuntos relacionados com habitação, regularização fundiária e ainda abrangeria o planejamento físico-territorial do município. Esta ação vem de encontro com uma das principais preposições do Plano Diretor que é a reorganização da estrutura administrativa da prefeitura.

\section{3- HABITAÇÃO, ACESSO À TERRA URBANIZADA E REGULARIZAÇÃO FUNDIÁRIA EM CUIABÁ}

Em Cuiabá, ocorreu um desequilíbrio devido às intensas correntes migratórias e especialmente as de baixa renda fizeram com que se adotasse, ainda que tardiamente, uma política para a habitação. Segundo Perfil Sócio Econômico de Cuiabá, volume III, pág. 213, o BNH passou a financiar moradias em Mato Grosso a partir de 1966, quando a COHAB-MT construiu o Núcleo Habitacional Cidade Verde. O não-atendimento à demanda levou a população desatendida a invadir terras públicas e privadas a partir da década de 1070. 
Em 1978 foi implantado o Projeto CURA (Comunidade Urbana para Recuperação Acelerada) nos bairros Araés, Lixeira, Quilombo, sendo seu objetivo a racionalização do solo urbano, a promoção de serviços de infraestrutura urbana e a redução das distorções causadas pela especulação imobiliária. Com os benefícios, grande parte da população não conseguiu permanecer nas localidades, sendo praticamente expulsas para regiões periféricas. Com a extinção do BNH, em 1986, a situação ficou muito crítica por conta do corte de recursos para a habitação por parte do governo federal. Em 1996, tornou-se insustentável com a extinção, após 30 anos de serviço e 40 mil habitações construídas, da COHAB. A década de 1990 seguiu praticamente sem a participação dos governos na produção de habitação na região. Com isso, surgiram mais de 80 ocupações irregulares em Cuiabá, a cidade ilegal chegou a ser maior que a legal sendo que $75 \%$ das edificações conviviam com algum tipo de irregularidade. Frente ao agravamento do problema, em 1984 foi criado o Programa Terra da Gente (PROTEGE), regularizando até o ano de 1994, 10.000 lotes através de cartas de aforamento.

Em 1999, Lei Complementar nº 055/99 criou a Agência Municipal de Habitação (uma autarquia) com finalidade de planejar e executar a política urbana do município, e instituiu também o Fundo Municipal de Habitação Popular (Fumhap) para administração dos recursos financeiros da Agência. O registro no Programa Habitar Brasil/BID destinou dois milhões para a estruturação do órgão no começo de 2000.

Entre 1990 e 2005 foram aprovados 34 loteamentos com um total de 20.786 lotes; foram regularizados 19 loteamentos totalizando 25. 142 lotes; e aprovados 60 condomínios horizontais e núcleos habitacionais, totalizando 8.155 casas ou lotes.

Os números do setor da habitação, em Cuiabá estão no quadro abaixo:

Quadro 07 - Programas habitacionais de Cuiabá

\begin{tabular}{|l|l|l|l|l|}
\hline Programa & Data & Unidades & Recursos & Fonte \\
\hline Prog.emergenciais & $\begin{array}{l}\text { Enchente } \\
1995\end{array}$ & 410 habitações & 5,6 milhões & Gov. Federal \\
\hline $\begin{array}{l}\text { Programas } \\
\text { emergenciais }\end{array}$ & $\begin{array}{l}\text { Enxurrada de } \\
2001\end{array}$ & 800 habitações & - & - \\
\hline HBB/BID & 2002 & 755 habitações & 9,8 milhões & HBB \\
\hline
\end{tabular}




\begin{tabular}{|l|l|l|l|l|}
\hline FETAB & 2005 & 263 habitações & - & Estado MT \\
\hline $\begin{array}{l}\text { Programa de } \\
\text { Residencial }\end{array}$ & 2001 & 956 & - & FGTS \\
\hline $\begin{array}{l}\text { Programa de } \\
\text { Arrendamento } \\
\text { Residencial }\end{array}$ & 2004 & 424 & - & FGTS \\
\hline $\begin{array}{l}\text { Programa de } \\
\text { Arrendamento } \\
\text { Residencial }\end{array}$ & 2005 & 1393 & - & FGTS \\
\hline \begin{tabular}{l} 
Terra da Gente \\
A partir de \\
\hline
\end{tabular} & 1984 & 12.754 ter. & - & - \\
\hline
\end{tabular}

Fonte: Agência Municipal de Habitação Popular de Cuiabá

Ao rever o Plano Diretor, Cuiabá se valeu de diagnóstico produzido pela Agência de Habitação, mas não chega a detalhes como a precariedade das condições de moradia.

$\mathrm{O}$ art. 15 estabelece uma série de diretrizes para a política habitacional do município sendo as principais:

- Articular a política habitacional do município em conjunto com órgãos federais e estaduais e a população, priorizando a habitação para famílias com renda até três salários mínimos.

- Elaborar o Plano setorial de habitação;

- Promover a melhoria das habitações existentes.

- Viabilizar a produção de habitações de interesse social.

- Coibir as ocupações em áreas de preservação ambiental e nas áreas de risco.

- Desenvolver projetos habitacionais que considerem as características da população local.

- Promover ações que melhore a qualidade de vida da população atendida com habitação de interesse social.

- Buscar preencher os vazios urbanos na região central, quando dotada de infraestrutura adequada, com habitação para a população de baixa renda.

- Promover a regularização fundiária. 
- Estimular as alternativas de associação ou cooperação entre moradores para programas habitacionais, incentivando a participação social e a autogestão.

- Promover a regularização fundiária e de edificações para a população de baixa renda, prestando inclusive assessoria jurídica e estabelecendo normas especiais.

- Criar programas para habitação rural.

Os objetivos concretos assim como os prazos para sua concretização deverão ser definidos pelo Plano de Habitação, já em elaboração com recursos federais. O PDDE estabelece ainda que deverão ser revistos e estabelecidos parâmetros físicos de moradia social, índices urbanísticos e de procedimentos de aprovação de projetos, de forma a facilitar a produção habitacional pela iniciativa privada, e segundo o inc. XVII pretende:

“estimular as alternativas de associação ou cooperação entre moradores para a efetivação de programas habitacionais, incentivando a participação social e a autogestão".

Quanto às áreas reservadas para a habitação de interesse social, as ZEIS, podemos dizer que são bastante heterogêneas e que foram demarcadas em localidades distantes do centro da cidade, em áreas onde boa parte já está ocupada, como já foi comentado, porém é visível a necessidade de investimentos nas localidades.

Alguns parâmetros de uso e ocupação do solo refletem a preocupação de diferenciação de áreas problemáticas.

Ao analisar o ordenamento jurídico do município, encontra-se a lei 108 de 17/07/85 que trata dos parcelamentos populares para fins sociais, onde diz que estes terão área mínima de duzentos (200) metros quadrados e frente mínima de dez (10) metros, exceto no caso de regularização fundiária promovida pelo Município, em áreas de conflito social e ocupação já consumada quando estas exigências poderão ser relegadas a critério da prefeitura. A Lei 2.298 de 17/07/85 diz que em todos os conjuntos habitacionais a serem construídos no município de Cuiabá, deverão constar obrigatoriamente os seguintes equipamentos: Creche, Parque Infantil, Quadra de Esportes e Centro Comunitário para a Associação de Moradores do Bairro.

Na Lei 044 de 23/12/1997 está estabelecido no Art.51, parágrafo $1^{\circ}$ que o lote mínimo permitido tem área igual a $125 \mathrm{~m} 2$ (cento e vinte e cinco metros quadrados). 
Já a lei 108 de 23/12/03 dispõe sobre critérios técnicos urbanísticos e edilícios para a elaboração e implantação de projetos de habitação popular de interesse social, e estabelece a via local mínima com $8 \mathrm{~m}$ de largura, e no mínimo $6 \mathrm{~m}$ de leito carroçável.

A Lei estabelece como critério para inclusão das famílias em programas de habitação social a renda familiar igual ou menor a 7 (sete) salários mínimos. Sendo que o art. 15, inc. XXV define como diretriz para a habitação de interesse social o controle da rotatividade das listas de pretendentes e beneficiários em programas de habitação e a transparência do processo. Também diz o PDDE que a sociedade deverá participar da elaboração do Plano Municipal de Habitação de Cuiabá.

Além da população, caberá ao Conselho Municipal através da participação direta na elaboração dos planos e das conferências que forem realizadas, o controle para o processo e as ações voltadas à habitação. Nesta área da habitação, foi criado o Conselho de Habitação e o Fundo de Habitação (Lei 0185 de 6 de maio de 2009). Como ações concretas, a agência conseguiu a remoção de 32 (trinta e duas) famílias do Praeirinho, bairro localizado as margens do rio Cuiabá cuja cota está abaixo da cota de inundação do rio é, portanto, constantemente atingido por enchentes. As famílias foram emergencialmente alojadas no ginásio do Bairro Lixeira e posteriormente relocadas no bairro Vila Nova. A dificuldade tem sido evitar que a área seja ocupada novamente, pois devido a não-utilização (ou reflorestamento) do local já existem famílias se instalando na área de proteção permanente, alimentando o ciclo remoção/reocupação.

Da mesma forma ocorreu com as famílias que ocupavam as margens do Córrego Gumitá, que foram removidas, porém como existe um projeto de urbanização sendo realizado, e consequentemente, o espaço utilizado, dificulta a reocupação.

A agência de Habitação de Cuiabá está trabalhando no Plano Local de Habitação de interesse Social do município, com recursos provenientes do Ministério das Cidades, com a pretensão de reduzir o déficit habitacional do município, que segundo o número de inscrições para casas realizadas pela Agência, gira em torno de quarenta mil unidades.

\section{4- AÇÕES PARA ACESSO À TERRA URBANIZADA, REGULARIZAÇÃO FUNDIÁRIA E HABITAÇÃO EM CUIABÁ}

O Plano de Habitação tem sido muito esperado, pois além de diagnosticar os problemas e as potencialidades no setor, traçará as metas para curto, médio e longo 
prazo, conforme esclarecimentos do técnico da Agência de Habitação - Sr. Carlos Anselmo de Oliveira, engenheiro civil de carreira da agência. O Plano será a referência para as políticas que serão desenvolvidas no município, inclusive para direcionar programas para a Zona Rural (que ainda não existe). O Plano deverá rever as exigências de equipamentos e os índices urbanísticos para os loteamentos de interesse social, como também as exigências mínimas para as casas, que atualmente são:

Área mínima de lote de $125 \mathrm{~m}^{2}$, a residência deve ter no mínimo $32 \mathrm{~m}^{2}$, testada mínima de $5 \mathrm{~m}^{2}$, quarto mínimo com $8 \mathrm{~m}^{2}$, cozinha mínima com $6 \mathrm{~m}^{2}$, banheiro mínimo com $2,4 \mathrm{~m}^{2}$, rua com caixa de rolamento mínima de $7 \mathrm{~m}^{2}$ e 2,5 de cada lado para calçadas.

Atualmente, os conjuntos habitacionais com mais de 80 (oitenta) residências devem possuir no mínimo, creche, escola, e área verde. O Plano será discutido no conselho de Habitação e em audiência pública, conforme prevê o Plano Diretor.

A Agência de Habitação não tem trabalhado, no momento, com mutirões, embora se admita que possa ser um meio viável para o combate ao déficit habitacional, e é sempre estimulado pela prefeitura (não especificando como a prefeitura age nestes casos). Quanto à regularização fundiária, existe uma equipe na agência que trata desta questão, orientando e dando apoio jurídico aos interessados, mas o Plano de Habitação é que irá realmente traçar as estratégias para que se possa levar a regularização fundiária para áreas problemáticas, os chamados "grilos", e outras áreas com problemas de documentação. A Agência está no momento viabilizando a regularização fundiária de dezesseis localidades, podendo ser estabelecidas normas diferenciadas para cada local, dependendo das peculiaridades de cada uma, inclusive com benefícios fiscais para os moradores, que não necessariamente necessitem se enquadrar na faixa de 0 a 3 salários mínimos, como diz o plano diretor (art. 15, inc. XXVII).

Segundo o Sr. Carlos Anselmo, o plano diretor vem sendo cumprido no que se refere a priorizar ao atendimento da faixa salarial até três salários mínimos, mas sempre em conjunto com as demais esferas do governo (existe a articulação entre com os programas do governo do Estado, e do Governo Federal via Caixa Econômica Federal). As residências para esta faixa de renda foram, até o momento, doadas. As habitações foram construídas com recursos da Prefeitura e do Governo do Estado, especialmente para quem vive sujeito às enchentes.

O sistema de informação ainda não foi implantado, e segundo o técnico será difícil fazer que as informações do Governo do Estado e União sejam compartilhadas 
entre eles e a população especialmente quanto ao déficit habitacional, que também será revisto pelo Plano de Habitação.

Conforme a entrevista, a prefeitura tem buscado melhorar as condições habitacionais da população de baixa renda, (doação de material de construção e outras ações pontuais) especialmente as do Jardim Florianópolis e Jardim Vitória, localidades muito carentes, localizadas na periferia da cidade (ao norte). Quanto à promoção do uso habitacional nas áreas já consolidadas, a Agência "busca" que se realize, mas nem sempre se consegue ( na verdade não se consegue), pois geralmente estes terrenos são mais caros. Da mesma forma, falou-se que é buscado o respeito às características do local, mas na prática, não é isto que se vê, pois os projetos não respeitam o hábito de se ter varandas, cozinhas abertas e janelas mais amplas devido ao clima quente do local. Segundo a assistente social, Senhora Francismari, programas sociais são desenvolvidos especialmente para cada comunidade instalada, assim como são desenvolvidas atividades de educação ambiental, visando a proteção do meio ambiente, das áreas de proteção permanente, de áreas de riscos e outras atividades que preserve o ambiente natural e os equipamentos coletivos. Também se desenvolvem programas que melhorem a renda das localidades, especialmente providenciando cursos profissionalizantes de acordo com a vontade dos moradores de cada lugar.

A prefeitura busca a parceria com as instituições de ensino (universidades), de forma especial através da disponibilidade de estágios para os universitários de diversos cursos na Agência de Habitação.

Na realidade são os fiscais da Secretaria de Meio Ambiente que devem realizar a fiscalização para que as áreas de proteção ambiental, as áreas públicas e as áreas de risco não sejam invadidas. Embora se reconheça que os fiscais não são em número suficiente, nem bem preparados (observação da autora) para todas as suas obrigações. Quanto à estrutura da Agência de Habitação, foi observado que faltam técnicos especialmente concursados.

Conclui-se, então, que por muito tempo a população mais carente de Cuiabá e Várzea Grande tiveram que obter moradia sem contar com a ajuda de programas habitacionais do poder público, visto que estes eram insuficientes para suprir as necessidades da população. Isto contribuiu para o surgimento de inúmeros bairros ilegais e em áreas de preservação permanente. Assim programas de regularização fundiária, e flexibilização da legislação para estes casos serão fundamentais para a melhoria da vida desta população. 
Por isso os Planos de Habitação que estão a caminho serão fundamentais para diagnosticar o problema e estabelecer ações e metas para o futuro.

Não falta espaço nas cidades para a construção de moradias, e o preço do solo não é impeditivo, isso somados aos incentivos do Governo Federal (programas como Minha Casa, Minha Vida e a facilidade de obtenção de crédito para aquisição de habitação) são fatores positivos para a melhoria do problema.

Cuiabá se apresenta estruturada para enfrentar as questões habitacionais, pois conta com a Agência de Habitação razoavelmente estruturada (mesmo não sendo o ideal). Porém Várzea Grande não, sendo que só agora está se estruturando o órgão municipal que tratará da questão pois isso já representa um grande avanço. 


\section{CAPÍTULO 07- MOBILIDADE URBANA}

Cuiabá, sendo a capital do Estado, é um polo regional de forma que se torna caminho natural para o Norte, sendo ponto de convergência de rodovias federais e estaduais. Várzea Grande sofre também as influências do tráfego intenso, especialmente durante a época do transporte da safra para as regiões Sul e Sudeste.

Os problemas de falta de estrutura nesta área foram diagnosticados pelos munícipes, que de forma geral, reivindicaram melhorias nas rodovias, qualificando, ou mesmo construindo, as ligações perimetrais. Isto é o que se constatou às margens da chamada Rodovia dos Imigrantes, que corta Cuiabá e Várzea Grande, sem sinalização adequada com péssima pavimentação, apenas uma pista para ir e outra para voltar e com trechos sem acostamento adequado. Esta é a principal saída para o Norte do Estado.

O que se vê nos trechos de rodovias que chegam ao Aglomerado Urbano é que as estradas ou rodovias se confundem com a malha das cidades, tornando-se barreiras causadoras de acidentes e deixando o trânsito complicado na cidade. A solução, segundo diagnóstico das duas cidades seria a qualificação dos trechos das rodovias que cruzam as cidades (como a construção de vias locais, por exemplo) e a construção de outras que fossem necessárias.

A malha viária das cidades apresenta descontinuidade, não se articulando em inúmeros trechos e fazendo com que o usuário dê grandes voltas para chegar ao seu destino. Quase sempre acaba sendo inevitável a concentração do tráfego nos principais corredores tornando o trânsito completamente engarrafado, especialmente nos horários de pico, causando transtornos para toda a população.

As cidades de Cuiabá e Várzea Grande se comunicam por apenas cinco pontes (contando com a da Rodovia dos Imigrantes), o que é muito pouco, frente às intenções de deslocamento da população, que acaba tendo que dar voltas e voltas, transitando por vias congestionadas para se locomover aos pontos desejados. Em Cuiabá a reclamação fica por conta da falta de pontes sobre o Rio Coxipó, que conta com apenas duas ligações (atualmente se espera o término da construção da terceira, na Avenida das “Torres”). A região do Coxipó abriga um imenso contingente de população, e é formada na grande maioria pelas classes mais humildes, nesta região se encontra também o Distrito Industrial de Cuiabá, e praticamente o único acesso para muitas das localidades é a AV. Fernando Correia da Costa, que vive congestionada. 
A pavimentação só possui boa qualidade nas vias principais, nas locais a regra é a precariedade, que se acentua quanto mais longe e pobre for o bairro, muitas são as ruas que não possuem pavimentação, elas se localizam geralmente nas periferias, mas, até nas localidades mais centrais se pode constatar a falta de pavimentação. No diagnóstico, a população (principalmente a de Várzea Grande) apontou como problema a falta de pavimento em ruas por onde circulam os ônibus de transporte coletivo.

As leituras técnicas e comunitárias de Cuiabá e Várzea Grande apontaram várias vias que deveriam ser qualificadas e outras construídas para a melhor circulação do trânsito no Aglomerado. Podendo ser citadas como exemplos a Av. das Torres em Cuiabá (onde falta a construção de um dos trechos e de pontes sobre o rio Coxipó), ligações entre as avenidas Fernando Correia e Arquimedes Pereira Lima, a continuidade das avenidas que margeiam o Córrego do Barbado, inúmeros viadutos (especialmente sobre a AV. Miguel Sutil - Perimetral) e duplicações. Em Várzea Grande, a continuidade das avenidas que proporcionam o contorno do aeroporto, efetivando condições seguras e adequadas de se ligar o grande Cristo Rei ao restante da cidade, ligações entre bairros em geral e entre a Av. Júlio Campos e a AV. da Guarita. Outras ligações entre Cuiabá e Várzea Grande foram citadas como de grande importância para a melhoria da circulação viária no Aglomerado.

Outra regra geral é a precariedade das calçadas (quando existem). Cuiabá e Várzea Grande não possuem nenhum programa para construção e recuperação de calçadas, nem tão pouco existe uma padronização, a regra é que cada um faça a sua calçada. Isto, contudo, acaba sendo muito ruim, pois cada um utiliza um material e um modelo diferente, faz a inclinação conforme sua necessidade e acabam transformando as calçadas (isto quando existem) em locais intransitáveis para pedestres e cadeirantes, tantos são os degraus que se observa.

Quanto ao transporte coletivo, existem três sistemas no Aglomerado urbano: o sistema de Cuiabá, o de Várzea Grande, gerenciado pelas suas respectivas prefeituras, e o intermunicipal, gerenciado pelo governo do Estado. Embora exista integração física entre eles, não há a obrigatoriedade de se definir a mesma tarifa para todos, ocorrendo frequentemente

três

tarifas

diferentes. 


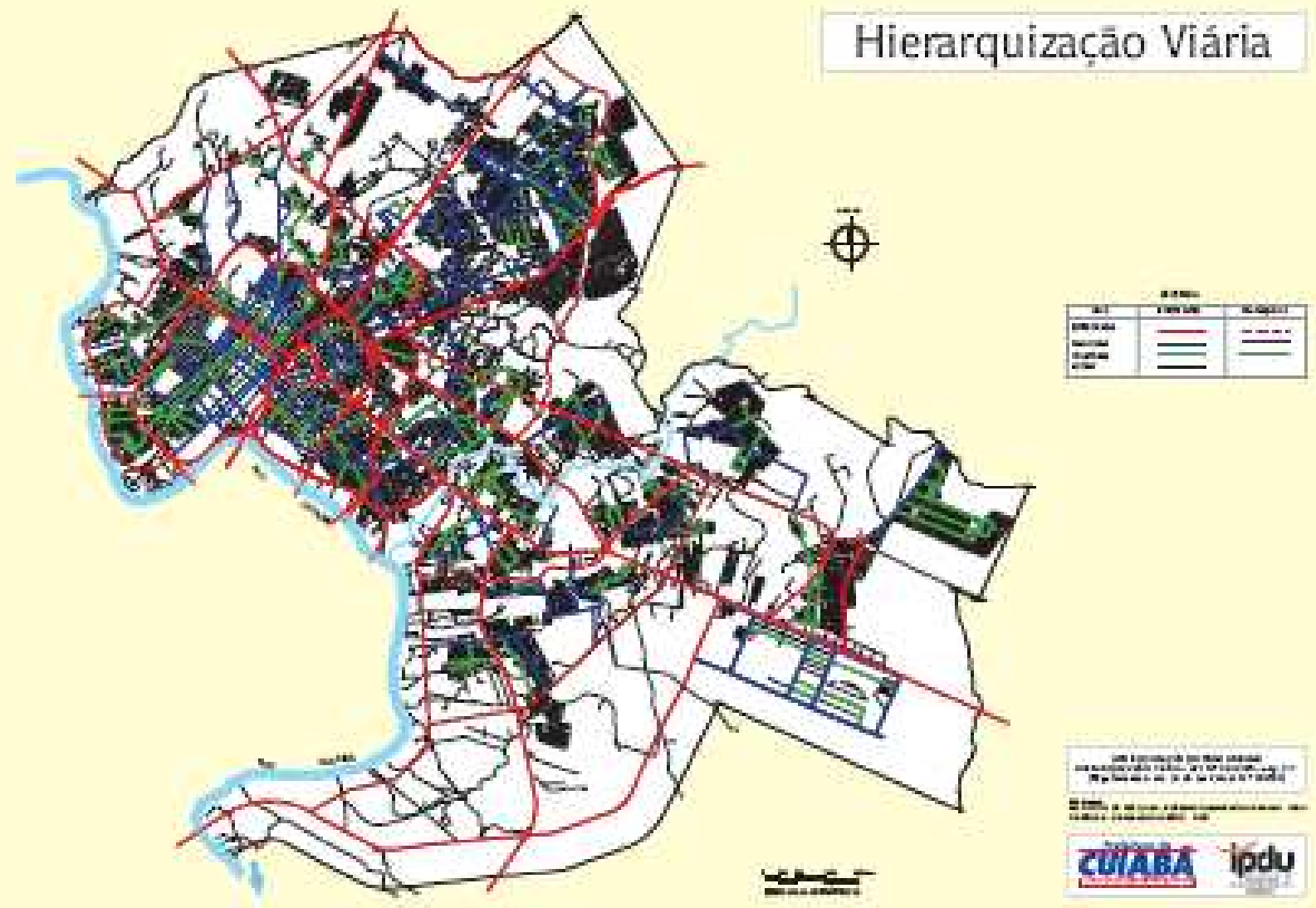

Figura 18 - Hierarquia viária de Cuiabá 


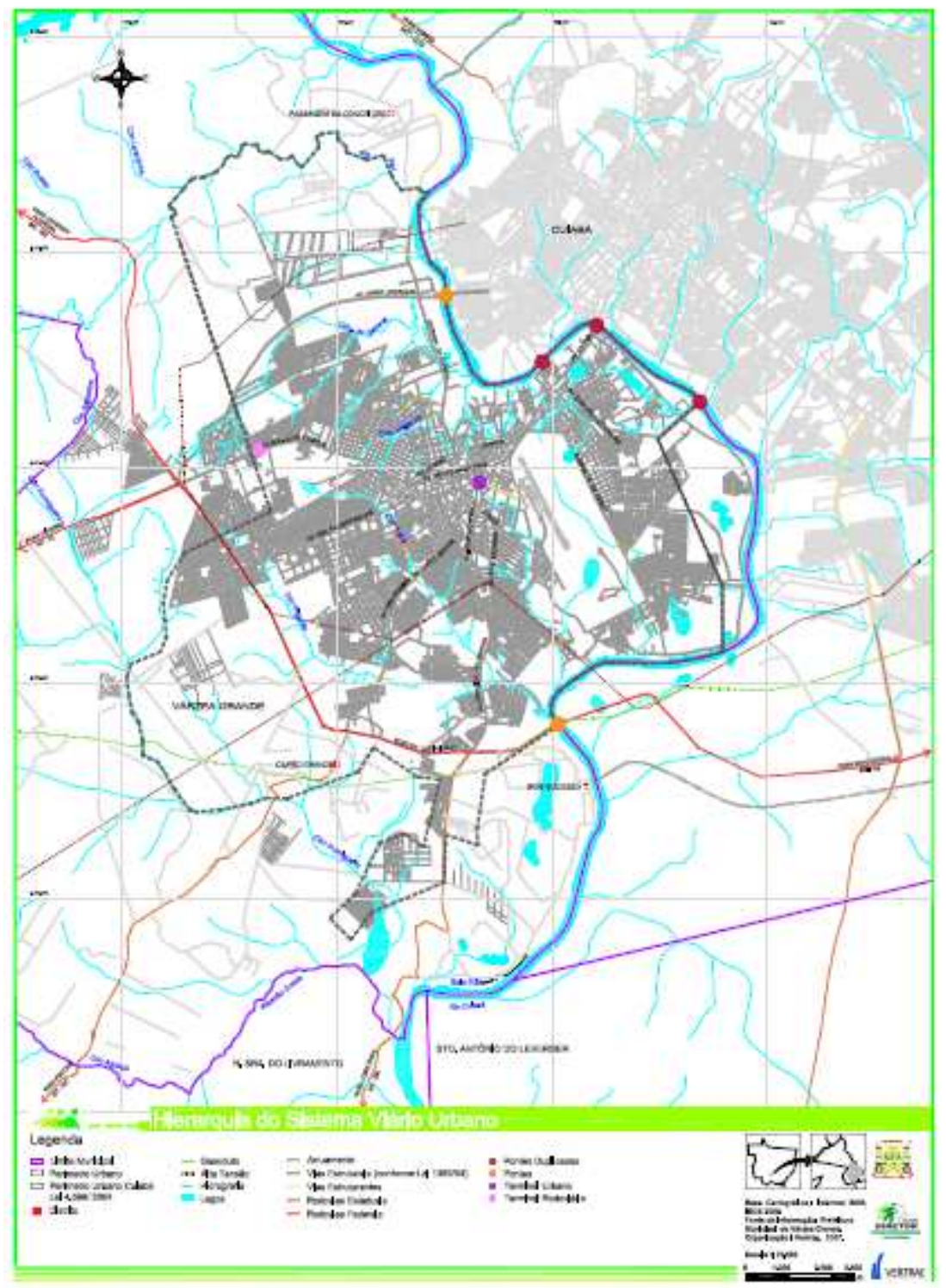

Figura 19 - Hierarquia viária de Várzea Grande

Fonte: VERTRAG 2007 
Em geral, as linhas são radiais, sendo que em Cuiabá podemos identificar algumas entre bairros, mas em Várzea Grande eles praticamente não existem e todo o sistema é integrado no Terminal André Maggi, no centro da cidade. Isto torna a viagem demorada e cansativa, sem contar que as linhas obedecem a um trajeto sinuoso nas proximidades do centro. O Terminal André Maggi apesar de pouco tempo de construção já está há muito inadequado, não comportando nem o número de passageiros que por ele transitam, nem o número de linhas, sendo que os ônibus não possuem sequer um pátio de espera no local (é utilizado o terreno em frete). Cabe ainda registrar que existem localidades urbanas que não são servidas por transporte coletivo, que algumas linhas trafegam demasiadamente cheias e não existe um sistema de ônibus especial para o aeroporto Marechal Rondon. Também a falta de terminal adequado para os ônibus interurbanos foi muito citada nas leituras comunitárias.

Tanto Cuiabá como Várzea Grande carecem de ciclovias (inexpressivas), e as calçadas não estão adaptadas para portadores de deficiências.

O Plano Diretor de Várzea Grande, refletindo a vontade da população, contemplou no art. 27 várias diretrizes e ações para a melhoria da mobilidade e do transporte na cidade, embora determine que sejam elaborados e implantados alguns planos municipais de transporte, além do Plano de Transporte Coletivo: o de Transporte Público Rural, Transporte Escolar, de Mobilidade e Acessibilidade, e de Transporte de Cargas, com regulamentação e estabelecimento de zonas de proibição de tráfego pesado.

\section{1- MOBILIDADE URBANA EM VÁRZEA GRANDE}

O Plano Diretor de Várzea Grande propôs como objetivos principais para o setor, a promoção da mobilidade tanto municipal como regional, a garantia da continuidade da malha viária, para inclusive ordenar os parcelamentos do solo, atender as demandas de uso e ocupação do solo urbano, hierarquizar as vias e definir padrões geométricos e operacionais para elas.

Existe no Plano Diretor de Várzea Grande a preocupação com a diversidade de modalidades e até a modalidade hidroviária é proposta para estudos. O Plano não diz expressamente que o transporte público é prioritário sobre os demais, mas podemos constatar que será a modalidade mais prestigiada por ser uma das funções sociais da 
cidade o acesso ao transporte público e à mobilidade e acessibilidade (art. $9^{\circ}$ ). No entanto, não se percebe se todas as modalidades estarão integradas de alguma forma.

Podemos dizer que houve, no Plano a preocupação com a inclusão social ao se propor:

- A melhoria da mobilidade urbana qualificando a circulação e o transporte urbano, viabilizando a acessibilidade de toda a população aos espaços e equipamentos urbanos, e promovendo a continuidade da malha viária (art. 27, inc. VI).

- A implantação de um Sistema Cicloviário Municipal (art. 27, inc. IX).

- Com a elaboração e implantação do Plano de Transporte Público Rural, que geralmente não é lembrado (art. 27, inc. XI).

- A elaboração e implantação do Plano de Mobilidade e Acessibilidade de Várzea Grande (art. 27, inc. XVIII).

O Plano não especificou nenhum instrumento para viabilizar as ações necessárias, e nem definiu nenhuma proposta para a zona a ser adensada. Não foi estabelecida uma política tarifária e nem princípios regulatórios para o setor, de forma que quase tudo deverá ser tratado em planos setoriais ou medidas isoladas.

Mesmo estabelecendo medidas para cada tipo de via, observa-se que existem vários casos na cidade em que a largura não é respeitada, e conjuntos habitacionais são implantados sem respeito à legislação (que já existia anteriormente ao Plano diretor de 2007), inclusive a largura das calçadas que em várias localidades onde são mais largas, são invadidas pelas casas.

Tabela 06 - Classificação hierárquica e dimensionamento das vias.

\begin{tabular}{|c|c|c|c|c|c|c|}
\hline \multirow[b]{2}{*}{$\begin{array}{l}\text { LASSE } \\
\text { DA VIA }\end{array}$} & \multicolumn{6}{|c|}{ DIMENSÕES MÍNIMAS } \\
\hline & $\begin{array}{l}\text { CAIXA } \\
\text { DA VIA } \\
\text { (a) }\end{array}$ & $\begin{array}{c}\text { CAIXA DE } \\
\text { ROLAMENTO(b) }\end{array}$ & $\begin{array}{c}\text { FAIXA DE } \\
\text { CIRCULAÇÃO }\end{array}$ & $\begin{array}{c}\text { FAIXA DE } \\
\text { ESTACIONAMENTO } \\
\text { PARALELO À VIA }\end{array}$ & $\begin{array}{l}\text { PASSEIO } \\
\text { (c) }\end{array}$ & $\begin{array}{c}\text { Ciclovia } \\
\text { bidirecional }\end{array}$ \\
\hline $\begin{array}{l}\text { Via } \\
\text { Regional }\end{array}$ & $*$ & - & $*$ & $*$ & * & $2,50 \mathrm{~m}$ \\
\hline $\begin{array}{l}\text { Via } \\
\text { Perimetral }\end{array}$ & $\begin{array}{c}\mathbf{3 8 , 0 0 ~ m} \\
\text { (quatro } \\
\text { faixas de } \\
\text { tráfego, } \\
\text { duas } \\
\text { marginais } \\
\text { ( com no } \\
\text { mínimo } \\
15,00 \mathrm{~m} \\
\text { de } \\
\text { largura }\end{array}$ & - & $3,50 \mathrm{~m}$ & $2,50 \mathrm{~m}$ & $3,00 \mathrm{~m}-$ & $2,50 \mathrm{~m}$ \\
\hline
\end{tabular}




\begin{tabular}{|c|c|c|c|c|c|c|}
\hline & cada) & & & & & \multirow[b]{3}{*}{$2,50 \mathrm{~m}$} \\
\hline \multirow[b]{2}{*}{$\begin{array}{l}\text { Via } \\
\text { Arterial }\end{array}$} & 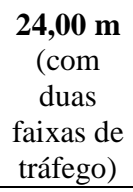 & $12,00 \mathrm{~m}$ & \multirow[b]{2}{*}{$3,50 \mathrm{~m}$} & \multirow[b]{2}{*}{$2,50 \mathrm{~m}$} & \multirow[b]{2}{*}{$6,00 \mathrm{~m}$} & \\
\hline & $\begin{array}{c}\mathbf{3 6 , 0 0} \mathbf{~ m} \\
\text { (via com } \\
\text { quatro } \\
\text { faixas de } \\
\text { tráfego e } \\
\text { canteiro } \\
\text { central } \\
\text { com no } \\
\text { mínimo } \\
5,00 \mathrm{~m} \text { de } \\
\text { largura) }\end{array}$ & $9,50 \mathrm{~m}$ & & & & \\
\hline \multirow[b]{2}{*}{$\begin{array}{l}\text { Via } \\
\text { Radial }\end{array}$} & $\begin{array}{l}\mathbf{2 2 , 0 0 ~ m} \\
\text { (com } \\
\text { duas } \\
\text { faixas de } \\
\text { tráfego) }\end{array}$ & $12,00 \mathrm{~m}$ & \multirow[b]{2}{*}{$3,50 \mathrm{~m}$} & \multirow[b]{2}{*}{$2,50 \mathrm{~m}$} & \multirow[b]{2}{*}{$5,00 \mathrm{~m}$} & \multirow[b]{2}{*}{$2,50 \mathrm{~m}$} \\
\hline & $\begin{array}{c}\mathbf{3 2 , 0 0 ~} \mathbf{~ m} \\
\text { (via com } \\
\text { quatro } \\
\text { faixas de } \\
\text { tráfego e } \\
\text { canteiro } \\
\text { central } \\
\text { com no } \\
\text { mínimo } \\
3,00 \mathrm{~m} \text { de } \\
\text { largura) }\end{array}$ & $9,50 \mathrm{~m}$ & & & & \\
\hline $\begin{array}{l}\text { Via } \\
\text { Coletora }\end{array}$ & $18,00 \mathrm{~m}$ & $12,00 \mathrm{~m}$ & $3,50 \mathrm{~m}$ & $2,50 \mathrm{~m}$ & $3,00 \mathrm{~m}$ & $2,50 \mathrm{~m}-$ \\
\hline Via Local & $13,00 \mathrm{~m}$ & $9,00 \mathrm{~m}$ & $3,30 \mathrm{~m}$ & $2,40 \mathrm{~m}$ & $2,00 \mathrm{~m}$ & - \\
\hline $\begin{array}{l}\text { Via } \\
\text { Parque }\end{array}$ & $* *$ & - & $* *$ & $* *$ & $* *$ & $2,50 \mathrm{~m}$ \\
\hline Via Rural & $* * *$ & - & $* * *$ & $* * *$ & $* * *$ & - \\
\hline
\end{tabular}

* Parâmetros a serem estabelecidos de acordo com as Classes de Projeto do DENIT e do DER/MT.

** Parâmetros a serem estabelecidos de acordo com o Projeto Urbanístico. *** Parâmetros a serem estabelecidos de acordo com as Classes de Projeto do DER/MT

Fonte: Plano diretor de V. Grande 2007.

O Plano prevê a integração viária e funcional com Cuiabá, o que significa que haverá a abertura para o diálogo (art. 27, inc. I) fato que já acontece, também deverá estar se estruturando, conforme art.27, inc. XVII, para promover a qualificação institucional dos órgãos responsáveis pelo planejamento e gestão dos sistemas viários e de transporte municipal, tendo em vista uma estrutura tão elementar que praticamente inviabiliza os estudos e projetos que precisam ser realizados.

$\mathrm{Na}$ legislação complementar do plano diretor (parte que é integrante deste) está a 
Lei do Sistema Viário de Várzea Grande (sem número).

A Lei supracitada classifica as vias, no art. $5^{\circ}$, em:

- Vias Regionais são os trechos urbanos das Rodovias, e precisam ser adequados com faixas laterais para o trânsito local, e serem duplicadas, para adquirirem duas faixas por sentido separadas por canteiro central e as passagens em desnível. (art. 15)

- Vias Perimetrais são as de contorno e precisam de adequação, tendo o acesso controlado por faixas paralelas laterais (marginais) e passagens em desnível e comportar ciclovias na lateral. (art. 16)

- Vias Arteriais têm como função principal atender às necessidades de altos volumes de tráfego de longo e médio percurso na área urbana, é adequado aos corredores de transporte coletivo com baias apropriarias e a implantação de ciclovias é prioritária. (art. 17)

- As vias Radiais são descritas como de média mobilidade e acessibilidade, fazendo a ligação norte-sul passando pelo centro, sendo próprias para a operação do transporte coletivo, tem a função de alimentar as vias Regionais, Perimetrais e Arteriais, e captar o trânsito das vias Coletoras. Comportam grande fluxo de veículos e podem estar dispostas em binários. A implantação de ciclovias é considerada prioridade. (art. 18)

- As vias Parques proporcionarão acesso à Macrozona Rural de Interesse de conservação e Preservação do Patrimônio Ambiental e Cultural e à Zona Especial de Interesse Cultural, Ambiental e Turístico, conformando-as e compondo projetos urbanísticos. (art. 29). Integrarão projetos urbanísticos para requalificar a paisagem, de ciclovias e com destinação do incremento ao turismo.

- As vias Rurais são as que dão acesso às diversas localidades da Macrozona Rural. (art. 31)

- As locais são todas as demais, que se integram ao uso e ocupação do solo e as demais atividades da cidade. (art. 30)

- As ciclovias são destinadas ao tráfego de bicicletas, e devem ser separadas da circulação de pedestre. Devem constituir um sistema. (art. 32)

A Lei estabelece diretrizes quanto ao sistema viário para a implantação de Loteamentos em Várzea Grande. São as principais: 
- As orientações para o traçado das vias deverão ser solicitadas à prefeitura.

- Deverá ser verificada a continuidade das vias oficiais adjacentes já implantadas.

Os anexos I e II trazem o mapa da hierarquização viária e a tabela para hierarquização e classificação de vias.

\section{2- AÇÕES PARA A MOBILIDADE URBANA EM VÁRZEA} GRANDE

Algumas ações têm sido realizadas na cidade. A SMTU de Várzea Grande tem desenvolvido o melhoramento de algumas vias da cidade em conjunto com o Governo do Estado, o superintendente da SMTU, Fernando Sé falou que as principais intervenções planejadas atualmente são:

- Duplicação da Av. Filinto Müller até o Bairro São Mateus.

- Duplicação da Estrada da Guarita.

- Duplicação da Av. Leôncio.

- Implantação e modernização de 44 semáforos na cidade.

- Intervenções na Av. FEB (com projeto de duplicação e melhorias como a construção de viaduto para a ligação do trecho interrompido da Av. Don Orlando Chaves).

- Intervenções na Av. Artur Bernardes (melhoria com a implantação de rotatória no entroncamento com a Av. Filinto Müller).

- Intervenções na Av. Alzira Santana (possibilidade de se fazer um binário);

- Tratamento da entrada dos bairros Ouro Verde e Ouro Branco.

- Rotatória no cruzamento com da Estrada da Guarita e Rodovia Mario Andreasa.

- Ligação da Av. Eduardo Gomes com a Alzira Santana (rotatória).

- Cruzamento da Av. Alzira Santana com a Av. Filinto Müller.

- Intervenções nas imediações do Aeroporto.

Outras intervenções em estudo são:

- $3^{\circ}$ faixa da Av. da FEB para corredor de ônibus.

- Ciclovias na Av. Filinto Müller, Leôncio e Av. Júlio Campos. 
- Projetos para pavimentação e recapeamento em todas as vias que passam transporte coletivo.

- Projeto de construção de terminal rodoviário (rodoviária) para Várzea Grande (nas proximidades do trevo do Lagarto), com shopping e terminal de ônibus.

- Estudos para reorganização do sistema de transporte a partir da construção de novos terminais para os ônibus. Seriam construídos terminais na futura rodoviária, entre os bairros São Mateus e IX de Maio, outro nas proximidades da COHAB, Cristo Rei.

Existem ainda estudos para a implantação de duas pontes sobre o Rio Cuiabá, sendo uma no prolongamento da Av. Barão de Melgaço e outra na Passagem da Conceição (Contorno Norte).

Nada foi feito, ou pensado para as calçadas, ciclovias e adaptação da cidade para portadores de deficiências físicas.

É evidente a falta de estrutura do órgão, que conta com apenas uma engenheira e 10 fiscais para a fiscalização dos ônibus, necessitando de completa estruturação administrativa e física, fator que compromete o desempenho da prefeitura, especialmente quanto ao conhecimento do que acontece no setor, a proposição de intervenções, planos e projetos.

Observa-se ainda que as ações voltadas para o transporte e trânsito possuem baixo grau de integração entre os municípios de Cuiabá e Várzea Grande, apesar de todo o diálogo e o esforço positivo realizado pelo AGLURB, em tantas reuniões do setor.

\section{3- MOBILIDADE URBANA EM CUIABÁ}

O Plano Diretor de Cuiabá já no art. $3^{\circ}$ fala que além do PDDE, o Plano de mobilidade e de transporte integrado urbano deverá ser instrumento norteador das ações no setor, e assim como Várzea Grande, coloca o transporte como princípio que propiciará "uma cidade para todos" (art. 50, inc. IV). Deixa claro que o transporte coletivo é prioridade (art. $5^{\text {ao }}$, inc. IX), mas deverá promover garantias de transporte intermodal, para maior competitividade para a produção local e regional.

Uma constante preocupação do PDDE de Cuiabá é a racionalização da infraestrutura existente, e particularmente considerando o sistema viário e o de 
transportes, para evitar a ociosidade e a sobrecarga.

Para o sistema viário, as diretrizes específicas foram traçadas no art. 10. As principais questões a ser enfrentadas, como já apontadas na leitura da cidade, foram:

- A estruturação viária de forma a garantir maior integração entre os bairros e maior mobilidade na cidade. Para tanto deverão ser construídas as vias laterais nos córregos, respeitando-se a faixa de preservação ambiental.

- A complementação das vias desarticuladas, construção de passagens em desnível nos seus principais cruzamentos especialmente das vias estruturais, e a construção de ciclovias e vias exclusivas para pedestres.

- Efetivar o desvio do tráfego rodoviário para vias perimetrais tornando assim o trânsito urbano mais seguro.

- Promover a pavimentação de vias, priorizando os trechos das vias que estão desarticuladas, as que são linha do transporte coletivo, e vias internas de bairros adensados.

- Definir nomenclatura das ruas e avenidas.

- Estabelecer critérios de planejamento e operação integrados com sistemas estaduais e federais.

- Promover estudos para as ligações viárias entre Cuiabá e Várzea Grande.

O que se nota, contudo, é que as ações concretas, demoram muito para sair do papel, então se torna difícil acreditar que alguma coisa melhore efetivamente (a avenida das torres se arrasta por mais de cinco anos sem ter sido terminada, e provavelmente será concluído sem o trecho que a ligaria a Av. do CPA, um dos principais corredores da cidade de forma que acabará por congestionar ainda mais a Av. Miguel Sutil, que já é intransitável). Restará a população aguardar o plano setorial tomar forma real para ver o se o trânsito e o transporte melhoram, mas os prazos não costumam ser cumpridos.

Muitas das diretrizes presentes no atual PDDE já faziam parte do Plano aprovado em 1992. No art. 13 estavam propostas a elaboração e implementação do Plano Setorial de Sistema Viário e Hierarquização Viária; estruturação da malha viária para integras as novas localidades, as vias marginais aos córregos, a complementação dos trechos desarticulados; a execução de ciclovias, exatamente como no texto atual. A definição de nomenclatura das vias e numeração das casas, as obras como recuperação de pavimento e construção de pontes e viadutos, e a estruturação do órgão municipal responsável pelo setor - o SMTU. 
Para o transporte, foi previsto:

- A elaboração de Plano de Transporte Integrado, em conformidade com o Estatuto da Cidade, sendo que o prazo estabelecido no PDDE seria de 180 dias, o que não foi cumprido ainda.

- Consolidar a integração do transporte coletivo no Aglomerado Urbano.

- Estabelecer política tarifária visando o equilíbrio do sistema.

- Priorizar o sistema de transporte coletivo, torná-lo acessível e realizar a adequação das vias por onde ele circula.

- Empenhar os responsáveis para a construção dos modais ferroviário, hidroviário e rodoviário para maior integração da região com países sulamericanos.

- Modernizar o transporte público de passageiros e reestruturar o setor. Implantar um sistema de transporte coletivo de grande capacidade.

- Reestruturar o gerenciamento do sistema de transporte através da reestruturação do Órgão Municipal SMTU, para a melhoria do nível de serviços.

- Adequar o modelo de gestão em conjunto com a comunidade, para implementar programas de pavimentação e de manutenção.

- Possibilitar às pessoas deficientes com dificuldades de locomoção e idosas condições adequadas e seguras de acessibilidade autônoma aos meios de transporte urbanos.

Sobre transporte e trânsito existem algumas leis que disciplinam o assunto como o Decreto no 2.754 de 03/05/1993, que estabelece normas no Serviço de Carga e Descarga na área central do município de Cuiabá.

A Lei de parcelamento do solo urbano, que fala sobre as regras a serem aplicadas para as vias de loteamentos e diz o seguinte quanto ao sistema viário:

- Os loteamentos terão vias com pistas de rolamento de 3,5m, sendo no mínimo duas, as vias com mais de quatro faixas deverão ter canteiro central.

- Os passeios deverão ser um de cada lado terá 30\% da largura e nunca será menor que $3 \mathrm{~m}$.

- As ruas exclusivas para pedestres terão largura correspondente a 5\% do comprimento e nunca serão inferiores a $4 \mathrm{~m}$.

- Ruas sem saída terão circulo de manobra com diâmetro mínimo de $20 \mathrm{~m}$. 
A Lei Complementar $n^{\circ} 108$ de 23 de dezembro de 2003, que dispõe sobre os critérios técnicos, urbanísticos e edilícios, para a elaboração e implantação de projetos de habitação popular de interesse social promovidos pelo município de Cuiabá, no art. 23, fala sobre o limite mínimo de vias em parcelamentos de interesse social conforme tabela abaixo:

Tabela 07 - Dimensão do sistema viário para Loteamentos Populares de Cuiabá

\begin{tabular}{|l|l|l|l|l|}
\hline & Pedestre & Mista & Local & Coletora \\
\hline $\begin{array}{l}\text { Largura mínima da via } \\
(\mathrm{m})\end{array}$ & 4,0 & 6,0 & 8,0 & 13,0 \\
\hline $\begin{array}{l}\text { Largura mínima leito } \\
\text { carroçável (m) }\end{array}$ & $\ldots$ & 5,5 & 6,0 & 9,0 \\
\hline $\begin{array}{l}\text { Largura mínima dos } \\
\text { passeios (m) }\end{array}$ & $\ldots$ & $\ldots$ & 0,6 & 2,0 \\
\hline $\begin{array}{l}\text { Declividade longitudinal } \\
\text { máxima }\end{array}$ & $\ldots$ & $15 \%$ & $15 \%$ & $12 \%$ \\
\hline $\begin{array}{l}\text { Declividade longitudinal } \\
\text { mínima }\end{array}$ & $0,5 \%$ & $0,5 \%$ & $0,5 \%$ & $0,5 \%$ \\
\hline
\end{tabular}

Fonte - Lei Complementar do Município de Cuiabá nº 198/2003

As diretrizes são corretas, porém não são apresentados instrumentos específicos para a realização, e nem ações para locais e trechos mais críticos. Transportes alternativos como as ciclovias são abordados de forma muito superficial. Desta forma, muitas das diretrizes propostas tenderão a se transformar em simples discurso, tendo em vista que faltam os planos, os projetos e especialmente, por se tratar de obras que requerem grandes desembolsos, falta de recursos financeiros.

\section{4- AÇÕES PARA A MOBILIDADE URBANA EM CUIABÁ}

O Plano setorial de Mobilidade Urbana foi concluído conforme estabeleceu o art. 11 do Plano Diretor de Desenvolvimento Estratégico de Cuiabá e estabeleceu as diretrizes e ações para o setor.

O Plano diagnosticou que Cuiabá possui $1.850 \mathrm{Km}$ de ruas, sendo $1.100 \mathrm{Km}$ (60\%) pavimentada e $750 \mathrm{Km}(40 \%)$ sem pavimentação, e que as grandes avemidas, que seriam os principais caminhos entre as diversas regiões da cidade são insuficientes tanto em número quanto em extensão. Realmente, a leitura da cidade, na fase de revisão do Plano Diretor já apontava o problema, inclusive da falta de ligação entre as vias 
estruturadoras e mesmo as avenidas com importância mais regionalizada, não faziam uma integração entre os bairros locais, o que não raramente significa dar uma grande volta para chegar ao bairro vizinho.

A frota dos veículos mais representativos em Cuiabá apresentou evolução conforme quadro abaixo, o que demonstra a necessidade de ações no setor para evitar

Quadro 08 - Frota de Veículos de Cuiabá

\section{FROTA}

\begin{tabular}{|l|l|l|l|}
\hline Tipo de veículo & Dez/2007 & Dez/2008 & Jun/2009 \\
\hline Moto e motoneta & 44.994 & 54.627 & 58.112 \\
\hline Automóvel & 112.915 & 127.188 & 134.325 \\
\hline Ônibus e micro-ônibus & 2.199 & 2.299 & 2.328 \\
\hline Reboque e semireboque & 6349 & 6982 & 7179 \\
\hline Caminhão e caminhoneta & 14.111 & 15.399 & 16.039 \\
\hline Caminhão trator & 1.541 & 1.789 & 7.665 \\
\hline Caminhonete & 19.032 & 21.251 & 22.357 \\
\hline Utilitário & 648 & 1.053 & 1.241 \\
\hline Outros tipos & 337 & 455 & 460 \\
\hline & & & $\mathbf{2 4 3 . 8 7 6}$ \\
\hline Total Geral & $\mathbf{2 0 2 . 1 0 1}$ & $\mathbf{2 3 1 . 0 4 3}$ & \\
\hline
\end{tabular}

Fonte: http://www.denatran.gov.br/frota.htm

O Plano de Mobilidade Urbana apresentou como problemática o transporte coletivo; a sinalização viária; a circulação viária; acessibilidade; pontos de conflitos e congestionamentos; e a ampliação da malha viária.

\section{a) Transporte Coletivo}

Foram apontados como problemas a serem enfrentados: a concepção do sistema tronco alimentador; a adequação do sistema viário tronco alimentador; a construção de terminais; os quantitativos e comparativos.

O trabalho apresenta como justificativa o fato de $75 \%$ das linhas do sistema de transporte municipal são radiais ou diametrais, com isto, as linhas se sobrepõem nos principais corredores da cidade (Av. do CPA, Av. Fernando Correa, Av. da Praínha, Av. 
Miguel Sutil principalmente), o aumento da quilometragem rodada pelos ônibus, e consequentemente, maior perda de tempo pelos usuários para chegarem ao seus destinos e o congestionamentos na área central, e nos principais corredores troncais.

O Plano prevê os corredores conforme figura 18, e a construção ou adequação de terminais, sendo que no final da implantação o sistema contará com o terminal do CPA, o Terminal Líbano, o do Carumbé, o do Coxipó, e o do Porto.

\section{CORREDORES TRONCAIS}

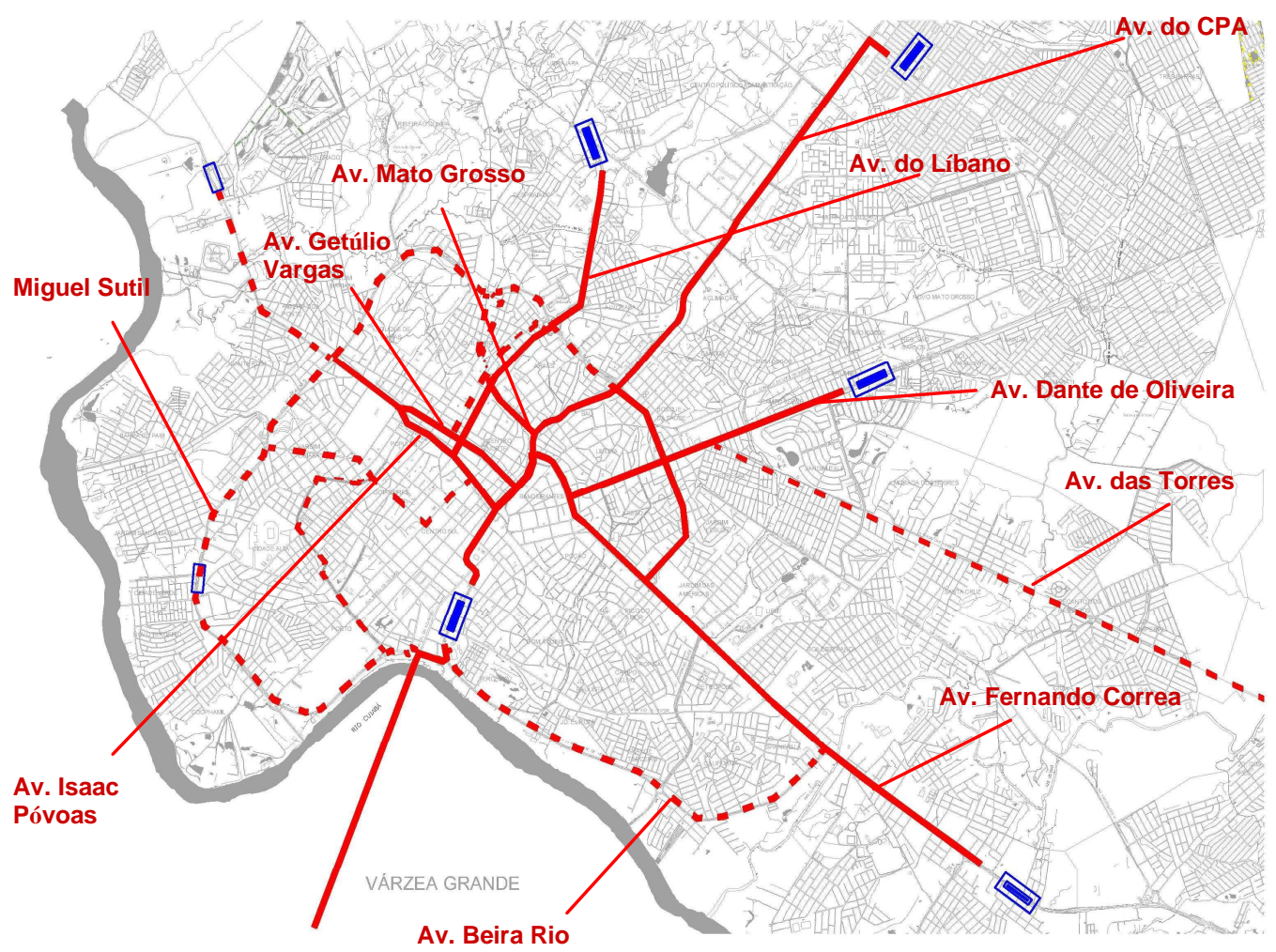

Figura 20 - Sistema Troncal de transporte proposto.

Fonte: SMTU 


\section{LOCALIZAÇÃO DOS TERMINAIS}

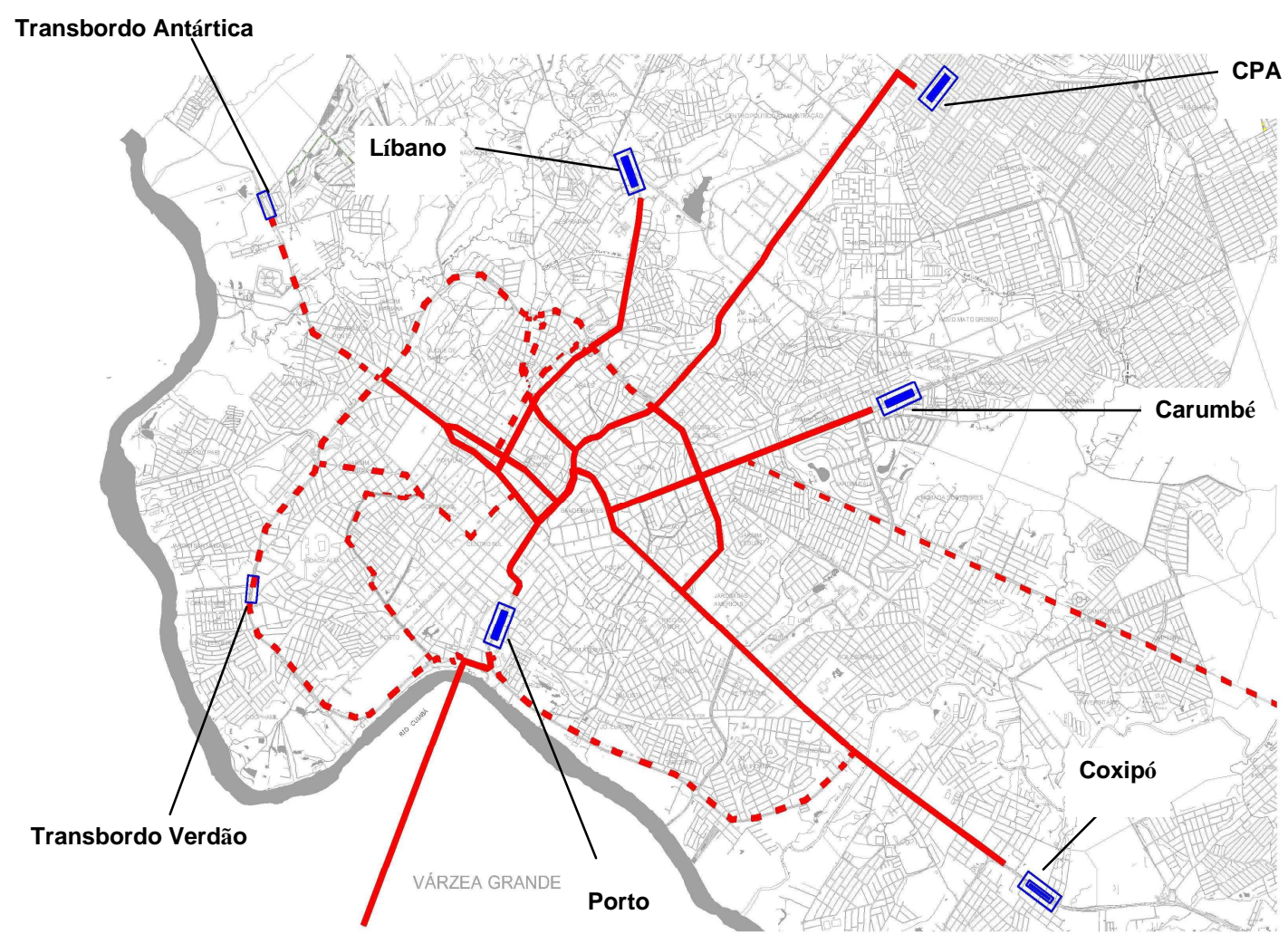

Figura 21 - Localização dos terminais

Fonte: SMTU

O terminal do Coxipó se localizará na Avenida Fernando Correa da Costa. Terá as seguintes linhas alimentadoras, e necessitará das adequações conforme quadro:

Quadro 09 - Alimentador e intervenções do terminal Coxipó

\begin{tabular}{|l|l|l|}
\hline ALIMENTADORAS & KM ÚTIL & ADEQUAÇÕES \\
\hline A1 - Parque Cuiabá & 10,4 & Recapeamento \\
\hline A2 - Real Parque & 12,4 & Recapeamento \\
\hline A3 - Parque Atalaia & 12,8 & Recapeamento \\
\hline A4 - Nova esperança & 31,2 & Pavimentação em 7,1 Km \\
\hline A5 - Pq. Residencial (via Mossoró) & 6,8 & Pavimentação em 1 Km \\
\hline A6 - Parque Residencial & 8,2 & $\begin{array}{l}\text { Recapeamento } \\
\text { Pavimentação em 6,5 Km e } \\
\text { implantação de pontilhão }\end{array}$ \\
\hline A7 - S. Gonçalo Beira Rio (Pq. Geórgia) & 10,2 &
\end{tabular}




\begin{tabular}{|l|l|l|}
\hline A8 - Tijucal & 8,2 & Recapeamento \\
\hline A9 - Osmar Cabral & 16,2 & Recapeamento \\
\hline A10 - Santa Laura & 16,8 & Recapeamento \\
\hline A11 - Liberdade/Foetaleza & 14,8 & Pavimentação em 700m \\
\hline A12 - S. Francisco/Passaredo/L. Azul & 11,8 & Pavimentação em 300m \\
\hline A13 - R. C. Marques/ S. Sebastião/ & 20,8 & $\begin{array}{l}\text { Recapeamento, via de } \\
\text { ligação entre Recanto do } \\
\text { Sol e Rondon e } \\
\text { pavimentação. }\end{array}$ \\
\hline Pascoal Ramos & Recapeamento \\
\hline A15 - Voluntários/Vista da Chapada & 29,2 & Recapeamento \\
\hline A16 - Pedra 90 & 24 & Recapeamento \\
\hline A17 - Pedra 90 (via Distrito Industrial) & 28,6 & Recapeamento \\
\hline A18 - Itapajé/Residencial Coxipó & 6,2 & Recapeamento \\
\hline A19 - Jd. Presidente/Vila Verde & 6,8 & Recapeamento \\
\hline
\end{tabular}

Fonte: Plano Setorial de Mobilidade

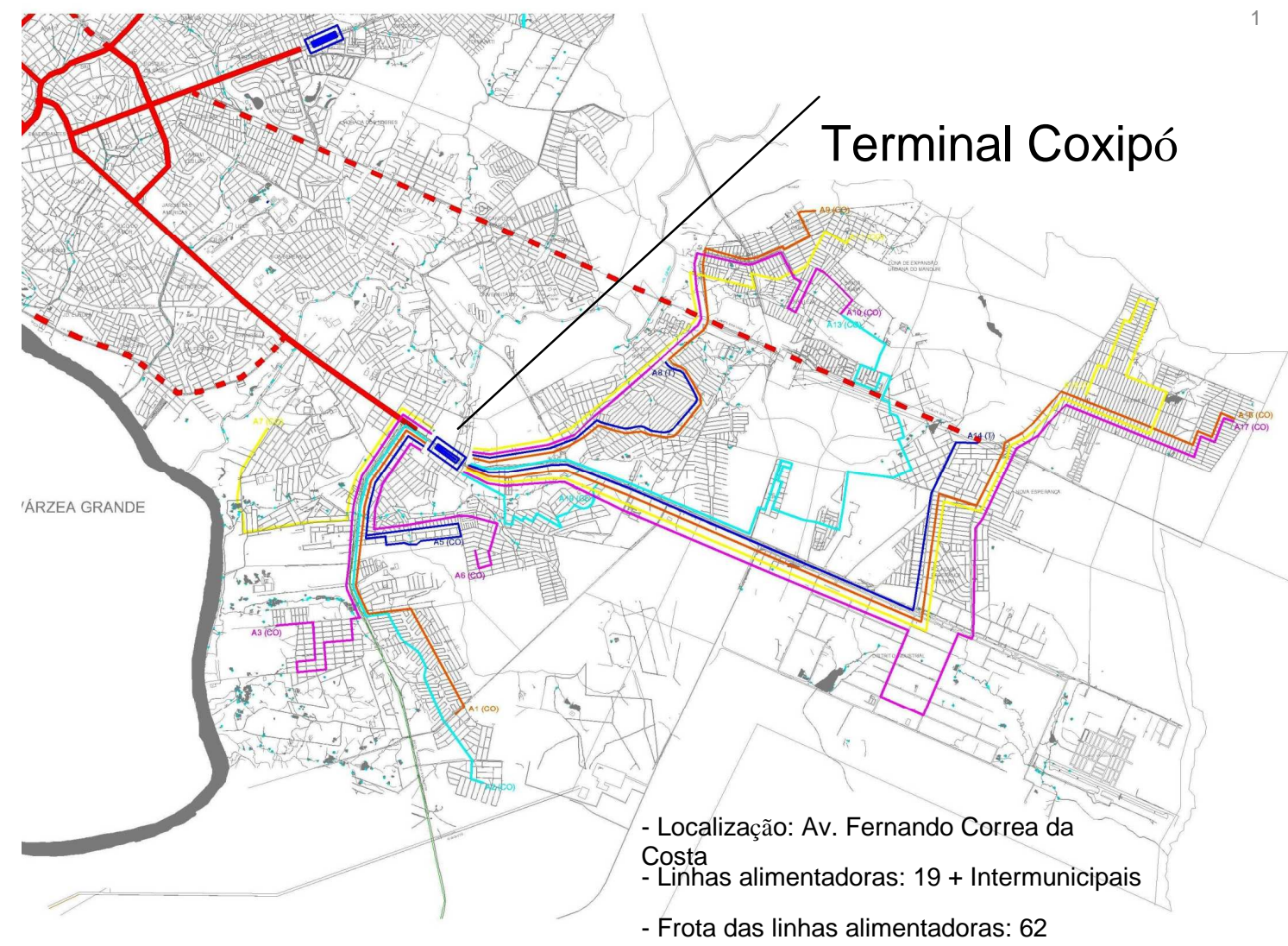

Figura 22 - Alimentadoras do terminal Coxipó Fonte: Plano Setorial de Mobilidade 
As novas linhas propostas diminuirão o tempo de viagem até o terminal, o intervalo e a frota, sendo o custo total de 34.200,00 considerando todos os serviços (incluindo reforma de baias e pinturas).

O terminal do Carumbé se localizará na Avenida Dante de Oliveira (Conhecida como Av. dos Trabalhadores) e terá as seguintes linhas alimentadoras, e necessitará das adequações conforme quadro:

Quadro 10 - Alimentadoras e intervenções do terminal Carumbé

\begin{tabular}{|c|c|c|}
\hline ALIMENTADORAS & KM ÚTIL & ADEQUAÇÃO \\
\hline $\begin{array}{l}\text { A1 - CPA III 9via Novo Mato } \\
\text { Grosso) }\end{array}$ & 7,6 & Recapeamento \\
\hline A2 - Dr. Fábio (via Altos da Serra) & 14,2 & $\begin{array}{l}\text { Recapeamento e Pavimentação } \\
\text { em } 2 \mathrm{Km}\end{array}$ \\
\hline A3 - Guaicurus (via Planalto) & 8,8 & $\begin{array}{l}\text { Recapeamento e Pavimentação } \\
\text { em } 700 \mathrm{~m}\end{array}$ \\
\hline A4 - Eldorado (via Sol Nascente) & 4,6 & Recapeamento \\
\hline A5 - Jd. Imperial (via Bela Vista) & 6,2 & $\begin{array}{l}\text { Recapeamento e Pavimentação } \\
\text { em } 1,2 \mathrm{Km}\end{array}$ \\
\hline A6 - Terra Nova & 7,8 & recapeamento \\
\hline A7 - CPA I (via Morada do Ouro) & 7,8 & $\begin{array}{l}\text { Recapeamento e ligação entre } \\
\text { Av. O. Canavarros e Dante de } \\
\text { Oliveira }\end{array}$ \\
\hline
\end{tabular}

Fonte: Plano Setorial de Mobilidade de 2008 


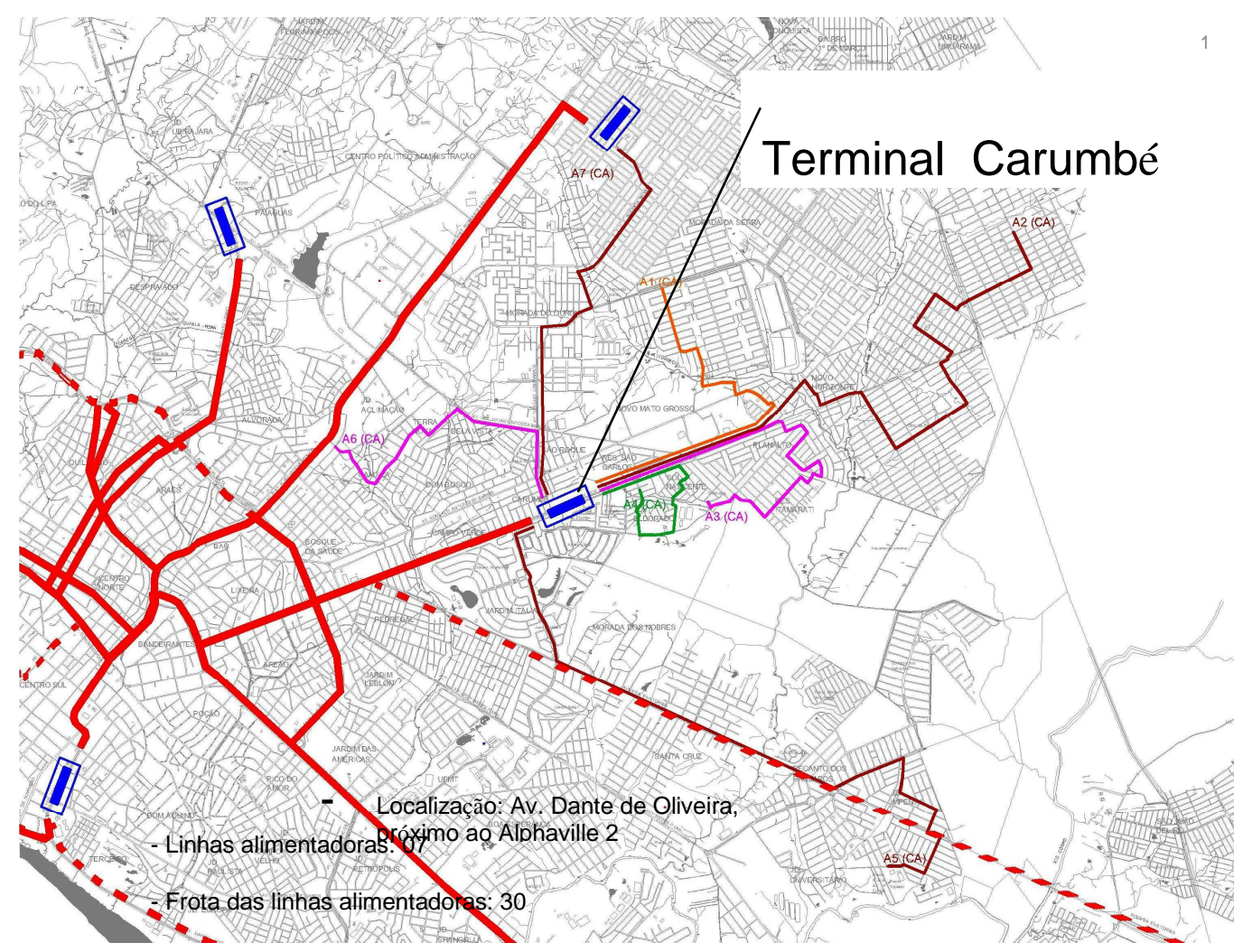

Figura 23 - Alimentadoras do terminal Carumbé

Fonte: Plano setorial de Mobilidade

Os investimentos para a implantação das linhas alimentadoras deste terminal será de R \$34.200,00. O terminal do CPA será no centro do bairro CPA I, onde já se encontra e terá as seguintes linhas alimentadoras, e necessitará das adequações:

Quadro 11 - Alimentadoras e intervenções do terminal CPA

\begin{tabular}{|l|l|l|}
\hline LIMENTADORAS & KM ÚTIL & ADEQUAÇÃO \\
\hline A1 - Florianópolis & 11 & Recapeamento \\
\hline A2 - Novo Paraíso & 6,4 & Recapeamento \\
\hline A3 - Picoli 9via Aroeiras) & 8,8 & Recapeamento \\
\hline A4 - Altos da Gloria (via V. Freitas) & 11,4 & Recapeamento \\
\hline A5 - Umuarama/Três Barras & 12,2 & Recapeamento \\
\hline A6 - 1 ${ }^{\text {M Março (via João Pinheiros) }}$ & 7,4 & Recapeamento \\
\hline A7 - Três Barras (via J. Pinheiros) & 9,4 & Recapeamento \\
\hline A8 - Jardim Paraná & 11 & Pavimentação de 400m \\
\hline $\begin{array}{l}\text { A9 - Terminal CPA/Shopping (via } \\
\text { morada do Ouro) }\end{array}$ & 12,2 & Recapeamento \\
\hline
\end{tabular}

Fonte: Plano Setorial de Mobilidade 
O custo das obras será de $\mathrm{R} \$ 34.200,00$.

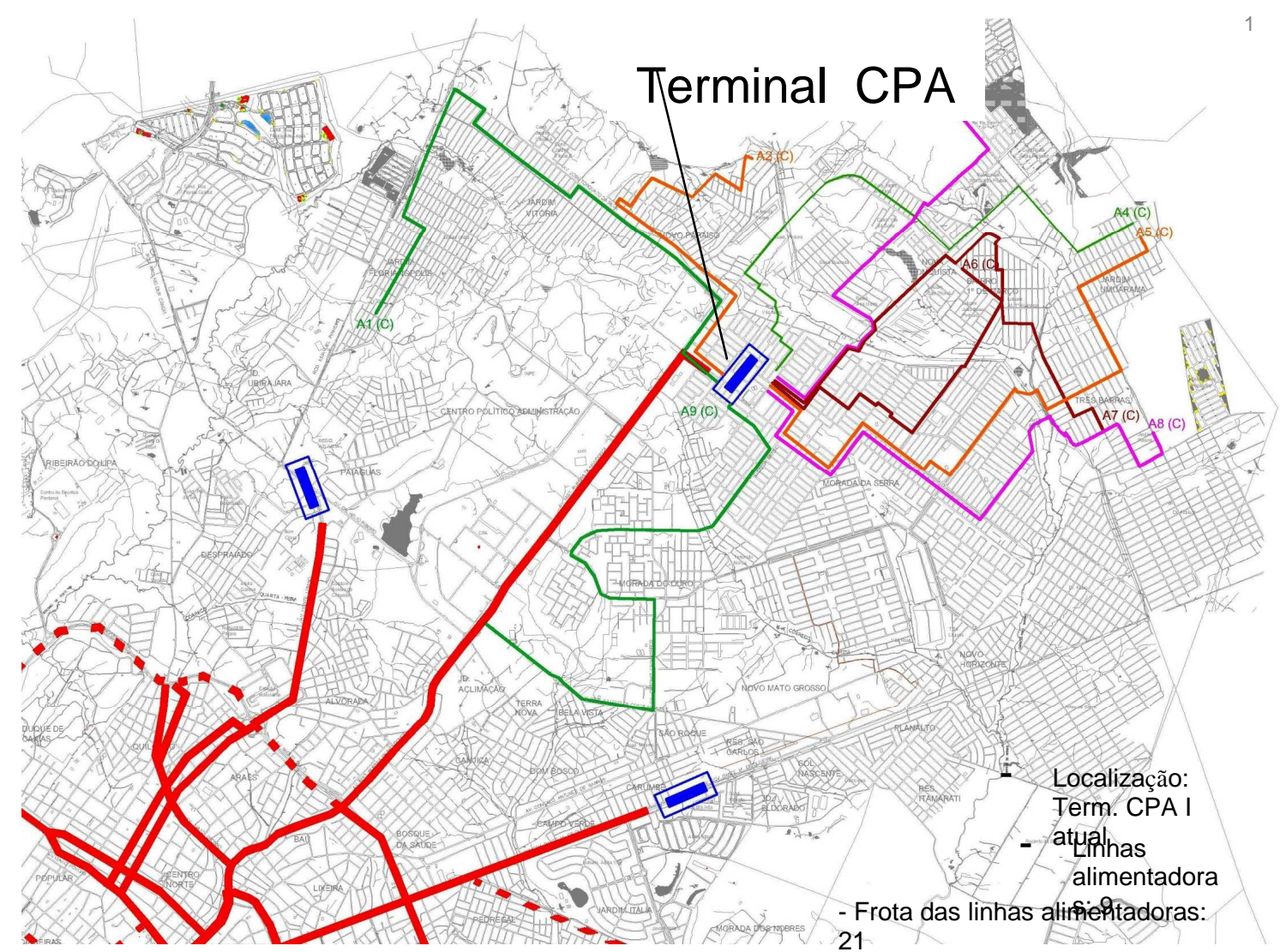

Figura 24 - Alimentadoras do terminal CPA Fonte: Plano Setorial de Mobilidade

O terminal Líbano se localizará na Av. República do Líbano, e terá as seguintes linhas alimentadoras, e necessitará das adequações conforme quadro:

Quadro 12 - Alimentadoras e intervenções do terminal CPA

\begin{tabular}{|l|l|l|}
\hline ALIMENTADORAS & KM ÚTIL & ADEQUAÇÃO \\
\hline A1 - Colorado (via Ribeirão) & 9,8 & $\begin{array}{l}\text { Recapeamento e ligação entre } \\
\text { Ribeirão do Lipa à Rodovia }\end{array}$ \\
\hline A2 - Guia & 31 & Recapeamento \\
\hline A3 - Mika (via Ubirajara) & 6,8 & Recapeamento \\
\hline A4 - Jardim Vitória (via F. Bradesco) & 9,4 & Recapeamento \\
\hline A5 - Jd. União (via Florianópolis) & 6,2 & Recapeamento e pavimentação \\
\hline A6 - DETRAN (Resd. Paiaguas) & 4,4 & Recapeamento \\
\hline A7 - Fórum (via Assembléia) & 8,4 & Recapeamento \\
\hline
\end{tabular}

Fonte: Plano Setorial de Mobilidade 


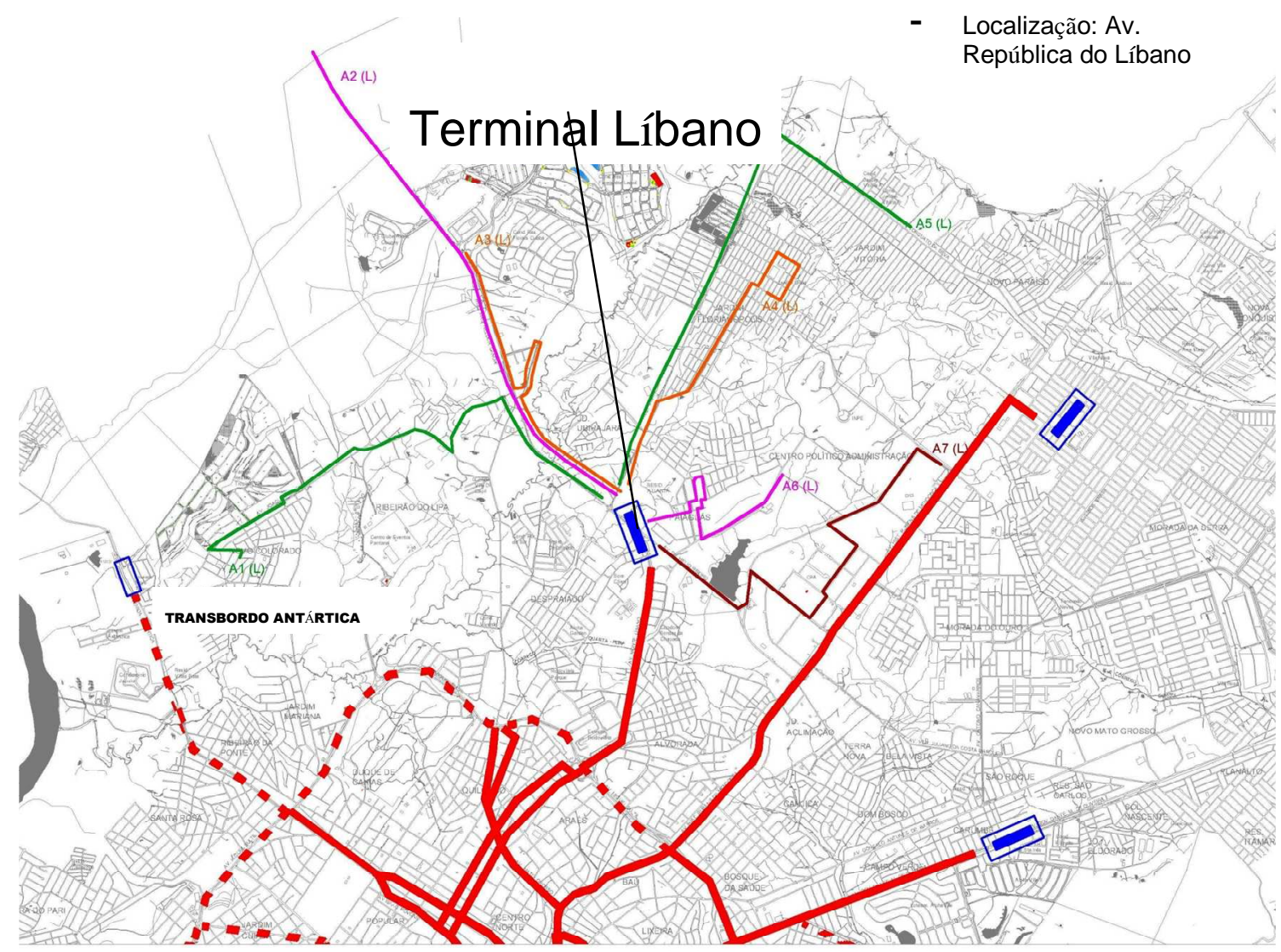

17 Linhas alimentadoras: $07+$ Intermunicipais

Figura 25 - Alimentadoras do terminal Monte Líbano Fonte: Plano Setorial de Mobilidade

O custo das obras para sua implantação serão $R \$ 34.200,00$.

O terminal Porto será construído na Av. Tem. Coronel Duarte, e terá três linhas alimentdoras e contará com uma frota de 17 ônibus. As linhas alimentadoras e as adequações serão conforme o quadro abaixo.

Quadro 13 - Alimentadoras e intervenções do terminal do Porto

\begin{tabular}{|l|l|l|}
\hline ALIMENTADORAS & KM ÚTIL & ADEQUAÇÃO \\
\hline A1 - Coophamil & 6,3 & Recapeamento \\
\hline A2 - Cidade Verde & 8,6 & Recapeamento \\
\hline A3 - Praeiro (via D. Aquino & & \\
\hline
\end{tabular}

Fonte: Plano Setorial de Mobilidade

As obras para sua implantação estão orçadas em $\mathrm{R} \$ 34.200,00$. 


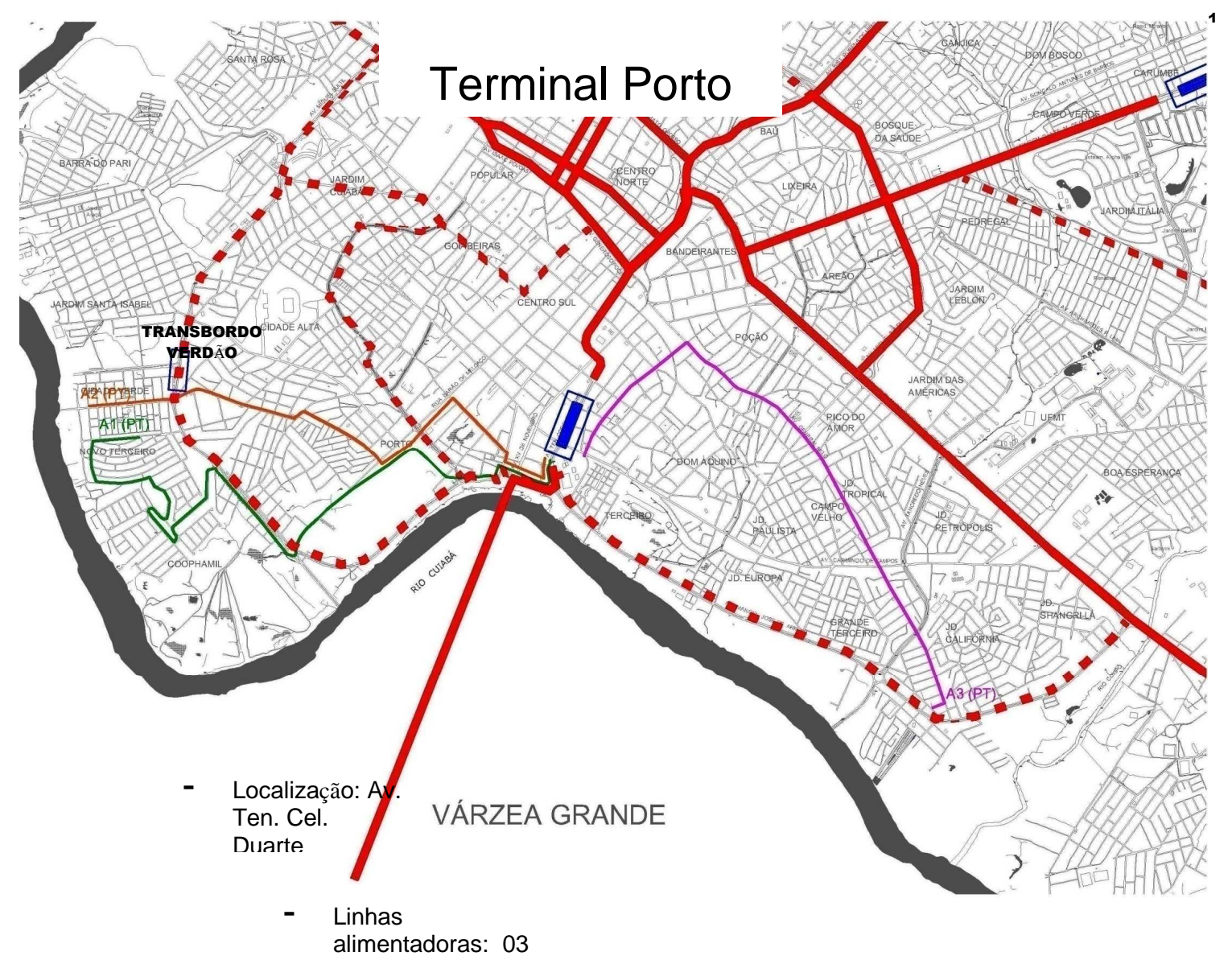

Figura 26 - Alimentadoras do terminal do Porto Fonte: Plano Setorial de Mobilidade

O Plano apresenta para o sistema troncal de transporte coletivo de Cuiabá quatro alternativas:
a) O Metrô;
b)VLT (Veículo Leve sobre Trilhos);
c) BRT (Bus Rápid Transit);
d) Convencional.

Segundo consultoria da Jaime Lerner Arquitetos Associados, o metrô levaria 9 anos para ser implantado e teria um custo de implantação de 2.010,00 milhões; o VLT levaria 5 anos para ser concluído, e custaria 404 milhões; o BRT seria implantado em 2,5 anos, pois as obras para implantação seriam apenas as adaptações viárias, os corredores, as estações de parada, e os veículos (adaptados ou adquiridos); o sistema convencional é o mais rápido de ser implantado e o de menor custo entre todos, sua implantação levaria apenas um ano e consumiria 55 milhões. 
Os corredores troncais seriam a Av. Fernando Correa, com 7,2 Km; a Av. Dante de Oliveira (Av. dos trabalhadores), com 3,3 Km; a Av. Rubens de Mendonça (Av. do CPA), com $9 \mathrm{Km}$; a Av. Getúlio Vargas, 5,2 Km e a Av. Miguel Sutil, com 3,7 Km, totalizando $33,3 \mathrm{Km}$.

Segundo técnicos da prefeitura, o sistema convencional foi o escolhido.

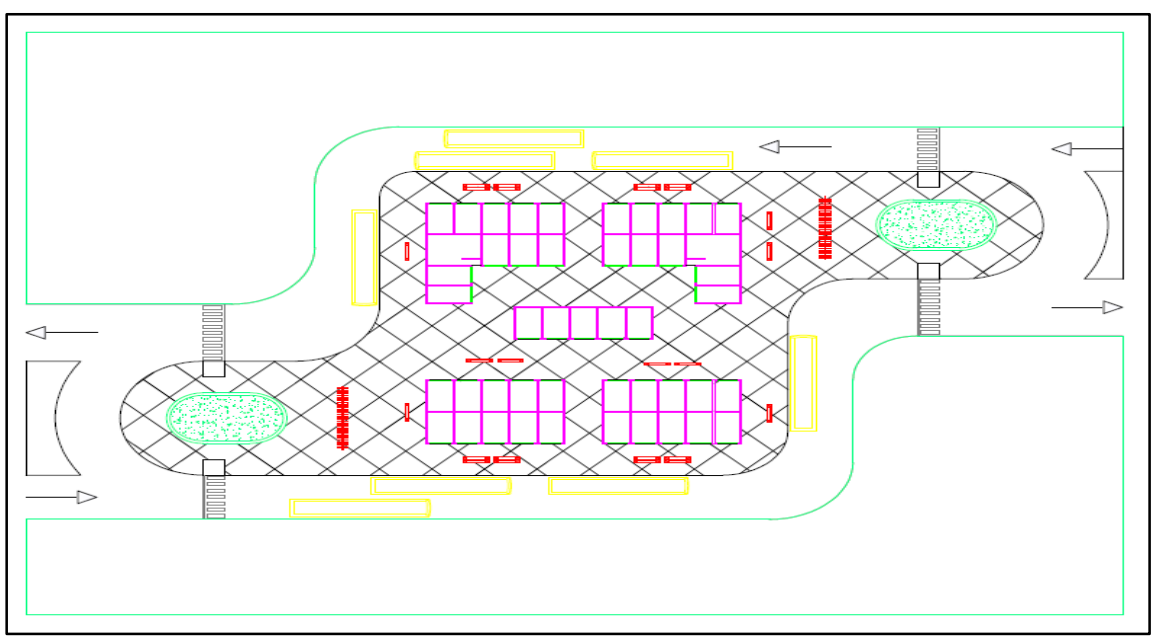

Figura 27 - Modelo dos terminais que serão construídos.

Fonte: SMTU

Os problemas apontados no seminário de apresentação do Plano de Mobilidade Urbana de Cuiabá foram as abaixo.

Quanto à sinalização viária:

- Falta de sinalização vertical e orientação quanto ao destino dos usuários.

- Necessidade de modernização, ampliação dos cruzamentos e a ligação de $100 \%$ dos cruzamentos semaforizados à Central Semafórica.

- Falta de sinalização e melhorias dos corredores das ruas Cândido Mariano, Marechal Floriano Peixoto, 24 de Outubro, Marechal Deodoro, Castelo Branco e Voluntários da Pátria.

- Falta de sinalização das travessias de pedestres.

- Deficiência na manutenção da sinalização vertical, horizontal e semafórica, e necessidade de aplicação de rotinas de trabalho.

- Implantação de sinalização vertical e horizontal em diversas localidades.

Quanto à circulação viária.

- A existência de problemas quanto a circulação de veículos pesados no perímetro urbano da cidade. 
- Necessidade de regulamentação (estudos) para horários de carga e descarga de mercadorias.

- Melhoria das rotinas de manutenção dos canteiros centrais das avenidas e das rotatórias.

- Estudos para melhoria das paradas e estacionamentos, inclusive a "Faixa Verde", e a fiscalização evitando o estacionamento em filas duplas especialmente em áreas escolares, de forma a melhorar as condições de trafego em certos pontos e horários.

- Relocação das feiras livres, especialmente as que funcionam em avenidas estruturais (como por exemplo, a da Jurumirins).

- Executar a remoção e apreensão de veículos parados em locais proibidos;

- Execução de obras necessárias nas vias públicas (tapa buracos, pinturas de faixas e outras obras).

- Construção das baias para acomodação do transporte público.

- Remoção e adequação dos redutores de velocidade.

- Construção de ciclovias.

Quanto a acessibilidade.

- Verificou-se a prática comum de estacionamento de veículos sobre as calçadas.

- A acomodação do comércio informal em áreas de Estacionamento Rotativo ou sobre o passeio público.

- A colocação de mesas e cadeiras sobre o passeio público, nos casos de bares e restaurantes.

- Falta de padronização das calçadas.

- Ausência de adequação das vagas de estacionamento destinadas às pessoas com deficiências.

- Falta de construção de rampas para acesso dos cadeirantes às calçadas.

- Ausência, ou falta de qualidade, de calçadas nas vias pavimentadas pelo município.

- Falta de semáforos com aviso sonoro.

O documento apresentado apontou os seguintes pontos de conflitos e de congestionamentos na cidade: 
- Entroncamento da Av. Cel. José Torquato com a Av. Rubens de Mendonça (bairro Novo Paraíso).

- Entroncamento da Av. Beira Rio com a Av. Fernando Corrêa da Costa.

- Entroncamento da Rua Poxoréo com a Av. República do Líbano (bairro Alvorada).

- Alça de saída de veículos do Terminal Rodoviário.

- Binário entre as ruas Pau Brasil e Nestor de Lara Pinto (bairro Jardim das Palmeiras).

- Entroncamento entre a Av. Das Flores X Av. Ramiro de Noronha X Rua Filinto Müller X Rua Estevão de Mendonça.

- Interseção entre as Avenidas Fernando Corrêa X Coronel Escolástico X General Vale.

- Entroncamento da Av. Hermínio Torquato da Silva com a Av. República do Líbano (Residencial Paiaguás).

- Rotatória do Terminal Rodoviário.

- Av. Dr. Meireles, entre o Trevo do Tijucal e a Av. Espigão.

- Entroncamento da Alameda 8 com a Av. Ulisses Guimarães (bairro CPA III).

- Entroncamento da Alameda B com a Av. William Coutinho (bairro CPA III).

- Binário entre a Av. Miguel Sutil e Rua Gov. José Fragelli (bairro Campo Velho).

- Interseção das avenidas Miguel Sutil e General Melo.

- Interseção das avenidas General Melo e Carmindo de Campos.

- Interseção das avenidas Carmindo de Campos e Jaques Brunini (bairro Jardim Paulista).

- Conversão à esquerda a partir da Av. Dante de Oliveira em direção a Av. Oátomo Canavarros.

- Travessia de pedestres na Av. Tenente Coronel Duarte, em frente ao Morro da Luz (Centro).

- Conversão à esquerda Av. CPA, acesso Av. Aclimação.

- Alças de retorno ao longo da Av. 31 de Março (bairro Goiabeiras). 
- Cruzamento entre as avenidas Barão de Melgaço e 8 de Abril (bairro Porto).

- Travessia de pedestre na Avenida Miguel Sutil em frente ao Supermercado Modelo (bairro Consil).

- Travessia de pedestre na Avenida Miguel Sutil em frente ao Ed. Santa Rosa.

- Binário entre as Avenidas Dante de Oliveira e Gonçalo Antunes de Barros;

- Binário da Rua Olvaldo da Silva Corrêa (bairro Despraiado).

- Duplicação da Av. Rubens de Mendonça, trecho compreendido entre o Comando Geral da Polícia Militar e o bairro Aroeira.

- Duplicação da Avenida Archimedes Pereira Lima, trecho compreendido entre o trevo do Tijucal e a Rua 20 (bairro Boa Esperança).

- Duplicação da Avenida Juliano da Costa Marques, trecho compreendido entre o bairro Bela Vista e a Avenida Dante de Oliveira (bairro Planalto).

- Cruzamento entre a rua Cândido Mariano e a Avenida São Sebastião.

- Cruzamento entre a Rua Marechal Floriano Peixoto e a Avenida Sao Sebastião.

Quanto à necessidade de ampliação da malha urbana, o seminário apresentou 72 intervenções, tendo sido apresentadas as seguintes:

\section{DETRAN}

1) Adequação viária (rotatória) no cruzamento das avenidas República do Líbano e Hermínio Torquato da Silva (acesso ao Residencial Paiaguás); Projeto executivo.

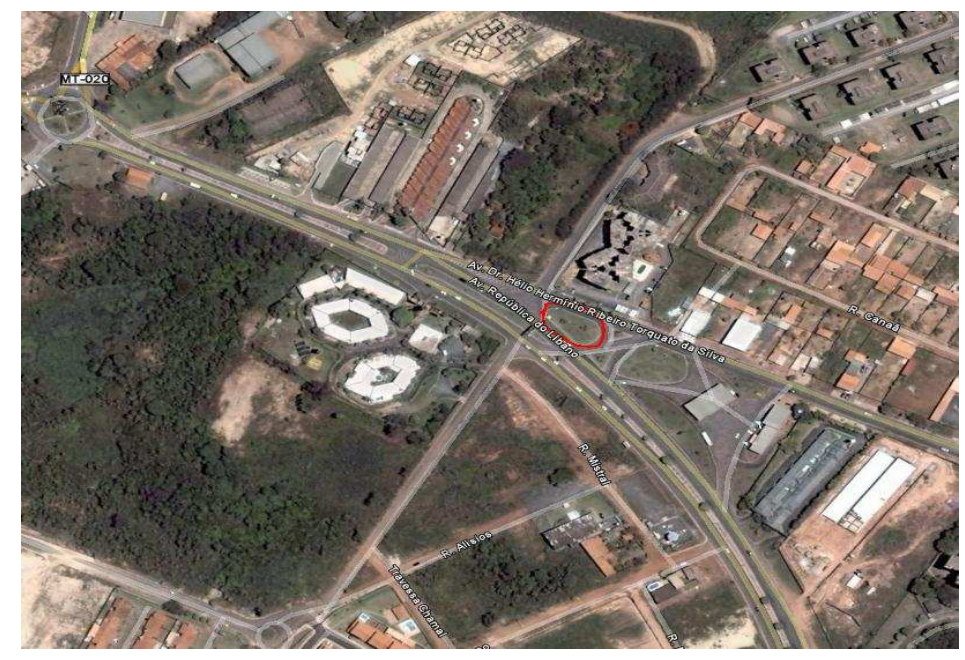

Figura 28 - Adequação viária avenidas República do Líbano Fonte: Plano Setorial de Mobilidade Urbana de Cuiabá (SMTU) 
2) Adequação viária (rotatória) no cruzamento da avenida República do Líbano e Rua Poxoréo (Rodoviária, Eng. Cássio Veiga de Sá).

\section{GOVERNO DO ESTADO}

3) Duplicação da Rodovia Emanuel Pinheiro (estrada de Chapada), trecho compreendido entre a MT 010 (Helder Cândia - estrada da Guia), e a MT 351 (Senador Vicente Bezerra - estrada do Manso.

\section{DNIT}

4) Construção de viaduto no cruzamento da avenida Lava Pés com avenida Miguel Sutil (trevo Santa Rosa).

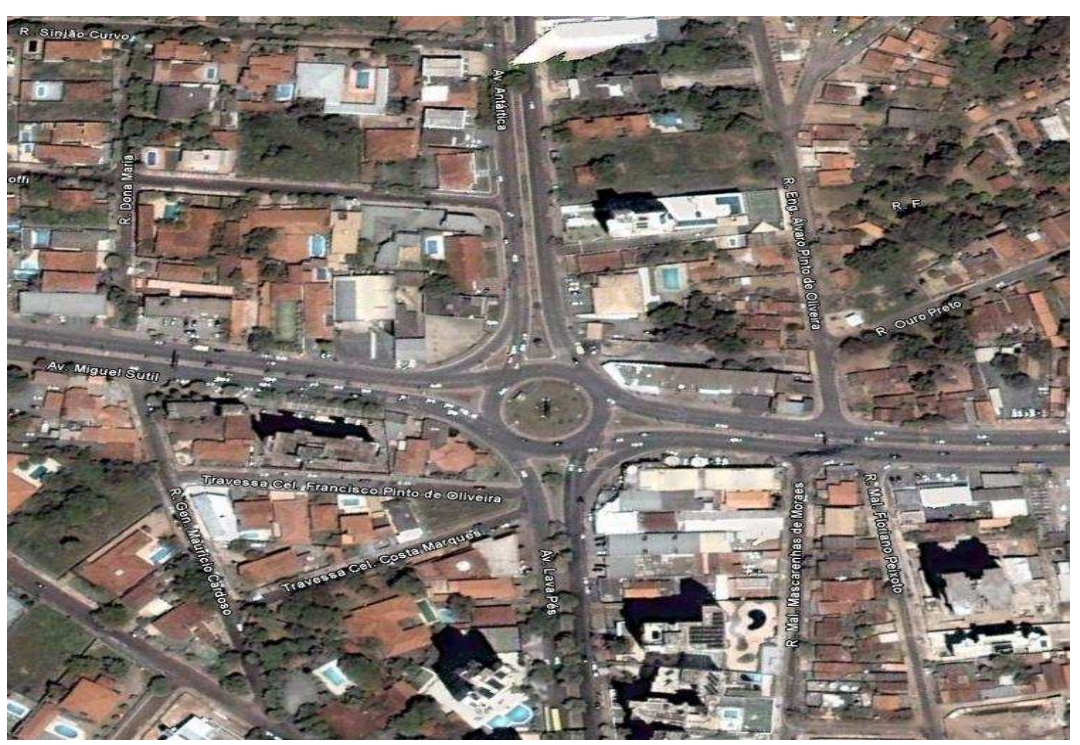

Figura 29 - Construção de viaduto no trevo do Bairro Santa Rosa Fonte: Plano Setorial de Mobilidade Urbana de Cuiabá (SMTU)

5) Construção de viaduto no trevo da ponte do Coxipó rotatória da Fernando Corrêa X Beira Rio. 


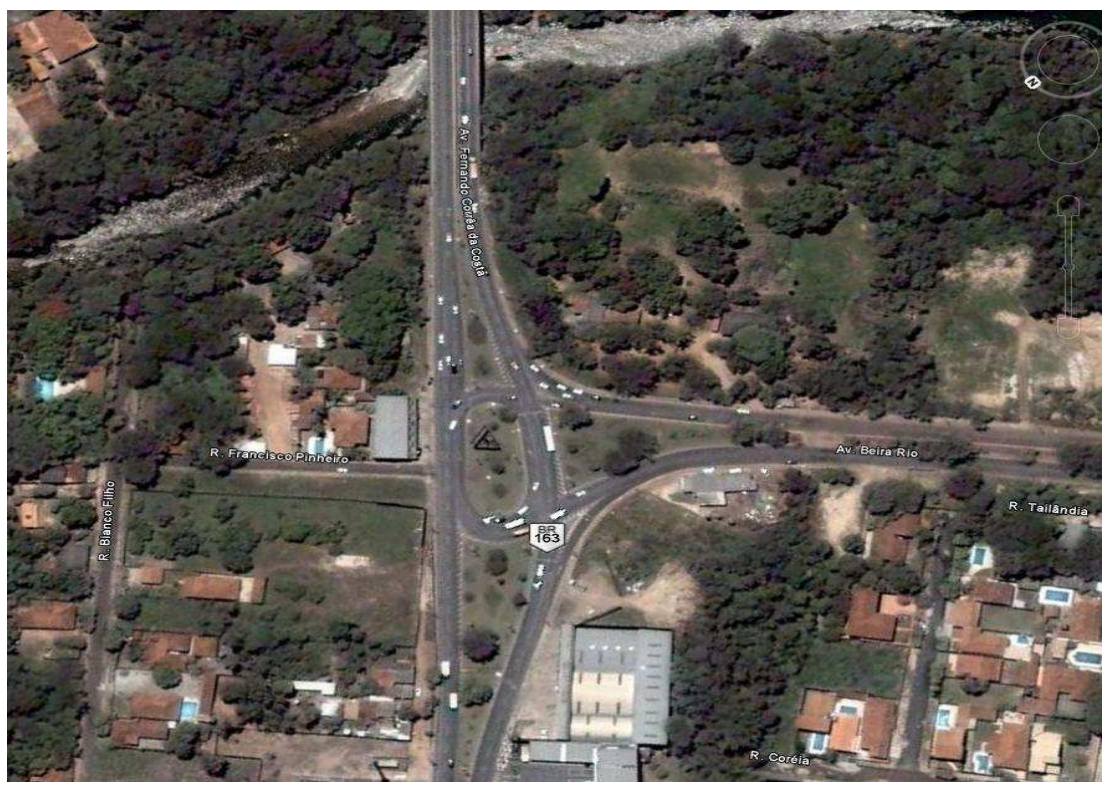

Figura 30 - Construção de viaduto no trevo da ponte do rio Coxipó Fonte: Plano Setorial de Mobilidade Urbana de Cuiabá (SMTU)

6) Ampliação da av. Fernando. Corrêa da Costa, (construção da $3^{\circ}$, terceira faixa) entre o $9^{\circ}$ BEC e a Av. Palmiro Paes de Barros (rodovia de Sto. Antonio).

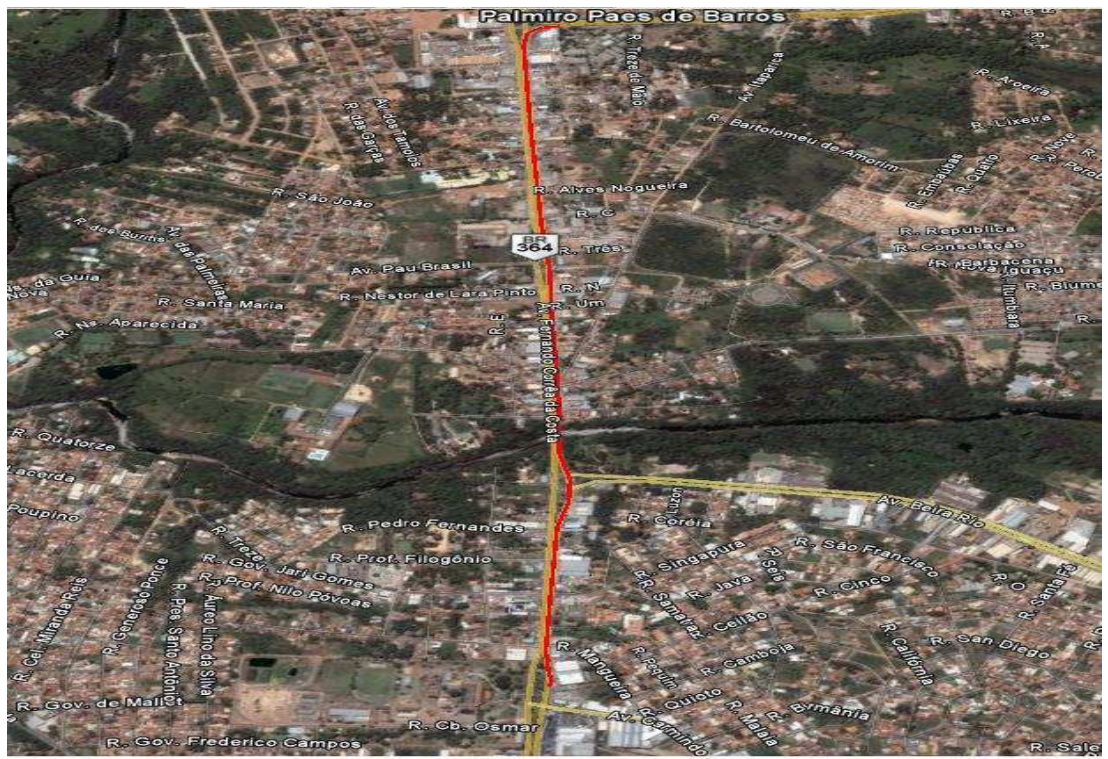

Figura 31 - Construção da $3^{\text {a }}$ pista da Av. Fernando Correa Fonte: Plano Setorial de Mobilidade Urbana de Cuiabá (SMTU)

\section{EMENDAS}

7) Duplicação da Av. Archimedes Pereira Lima (antiga Estrada do Moinho), entre o Trevo do Tijucal ao bairro Boa Esperança. 


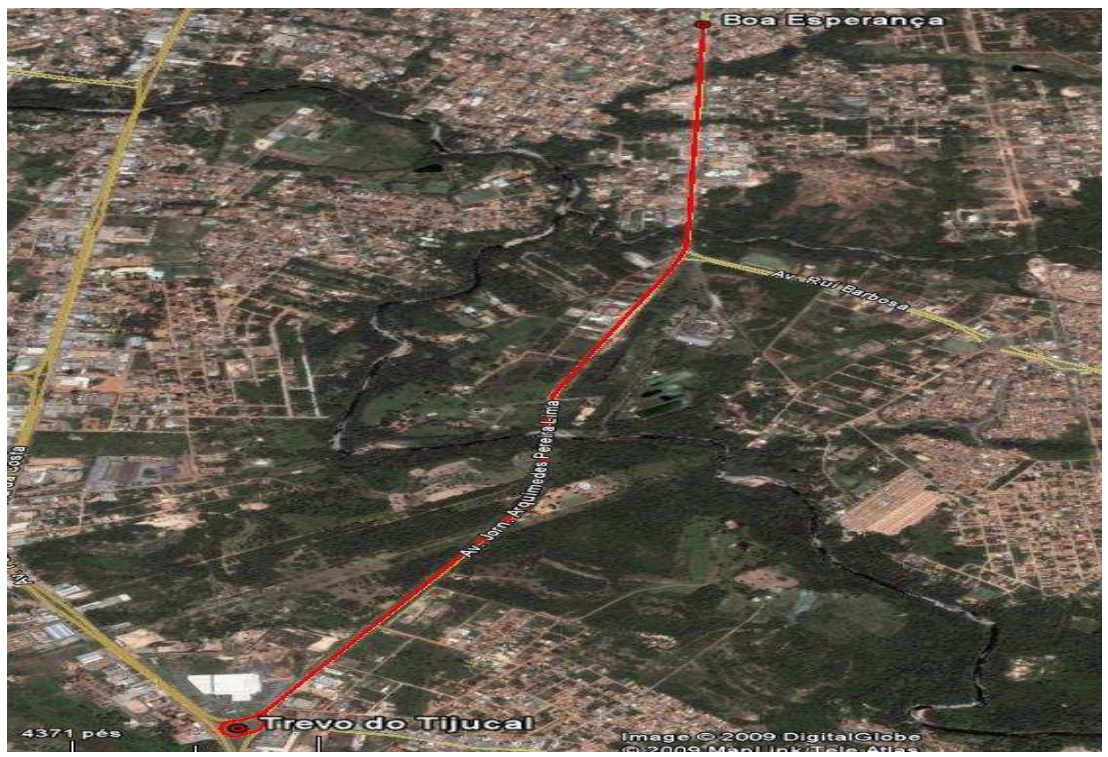

Figura 32 - Duplicação Av Archimedes P. Lima

Fonte: Plano Setorial de Mobilidade Urbana de Cuiabá (SMTU)

8) Construção de 1.300 metros da Av. Parque Gumitá, iniciando nas proximidades da associação dos delegados, trecho entre a Av. do CPA e a Av. Brasil, Av. principal do CPA II, e mais 6.000 metros de coletor tronco.

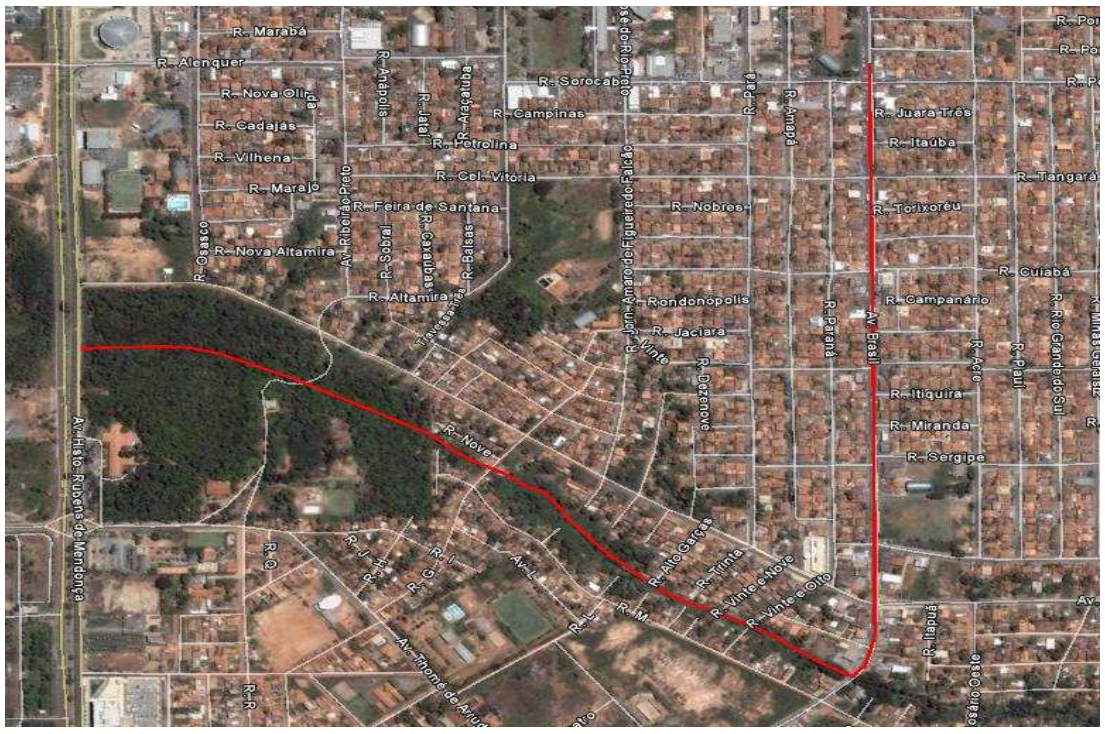

Figura 33 - Av. Parque Gumitá

Fonte: Plano Setorial de Mobilidade Urbana de Cuiabá (SMTU)

9) Duplicação da Av. Dante de Oliveira, trecho compreendido entre a Av. das Torres e a Av. Juliano da Costa Marques (lateral da Policlínica do Planalto).

10) Ligação entre a MT 010 (Helder Cândia, estrada da Guia) ao Ribeirão do Lipa (Vale dos Lírios) Rua Joaquim Moreno. 


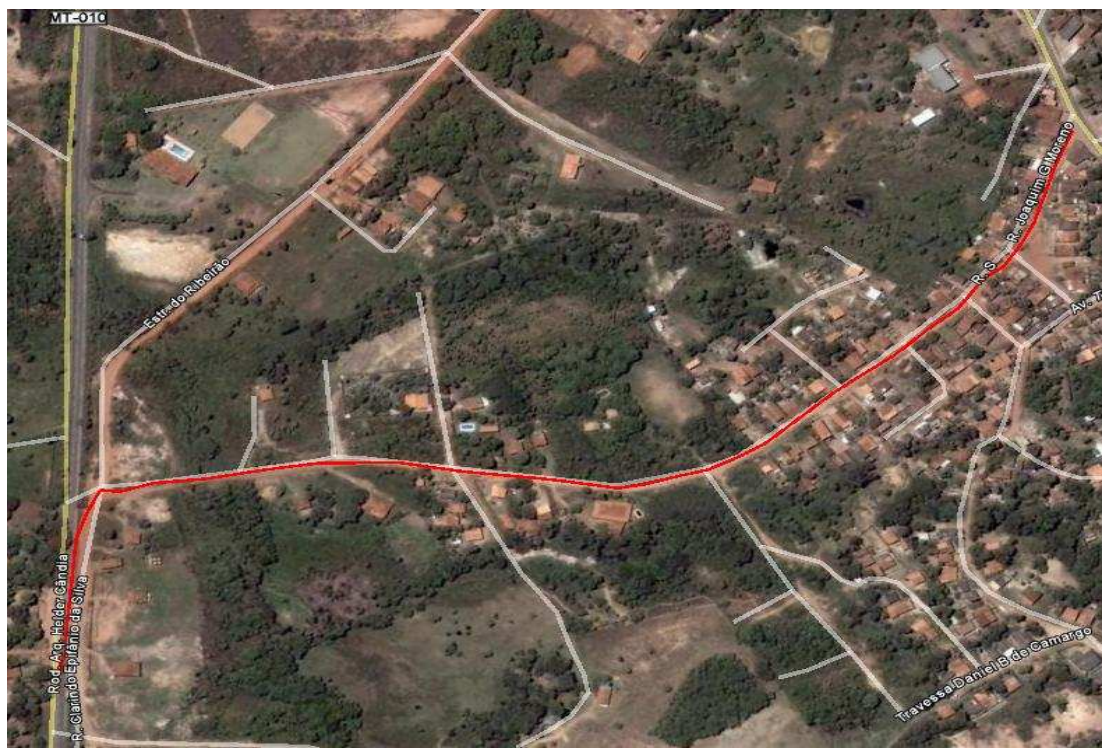

Figura 34 - Ligação entre a MT 010 ao Ribeirão do Lipa

Fonte: Plano Setorial de Mobilidade Urbana de Cuiabá (SMTU)

\section{MINISTÉRIO DAS CIDADES}

11) Duplicação da Av. Juliano da Costa Marques, trecho entre o trevo nos fundos do Pantanal Shopping e a Av. Dante de Oliveira (antiga trabalhadores).

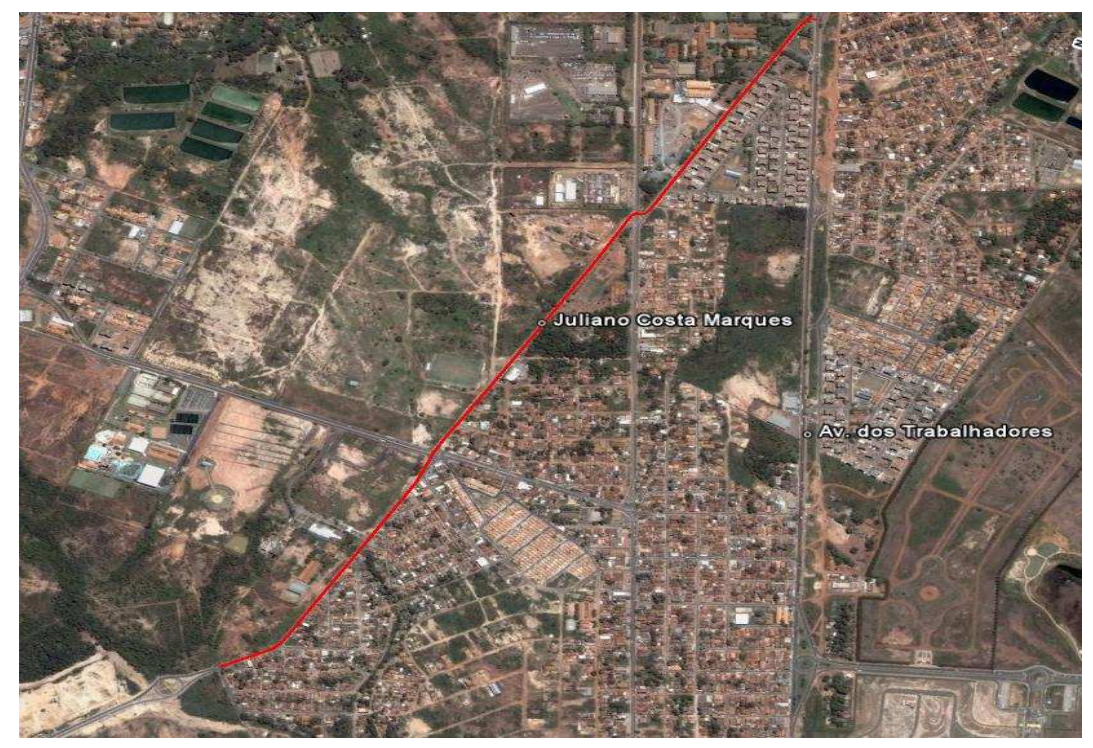

Figura 35 - Ligação Fundos do Pantanal Shopping e a Av. Dante de Oliveira Fonte: Plano Setorial de Mobilidade Urbana de Cuiabá (SMTU)

12) Construção de trincheiras no complexo da Av. Miguel Sutil,nas rotatórias com as avenidas Dante Martins de Oliveira, e Gonçalo Antunes de Barros. Tratamento do acesso a Rua Bela Vista. 


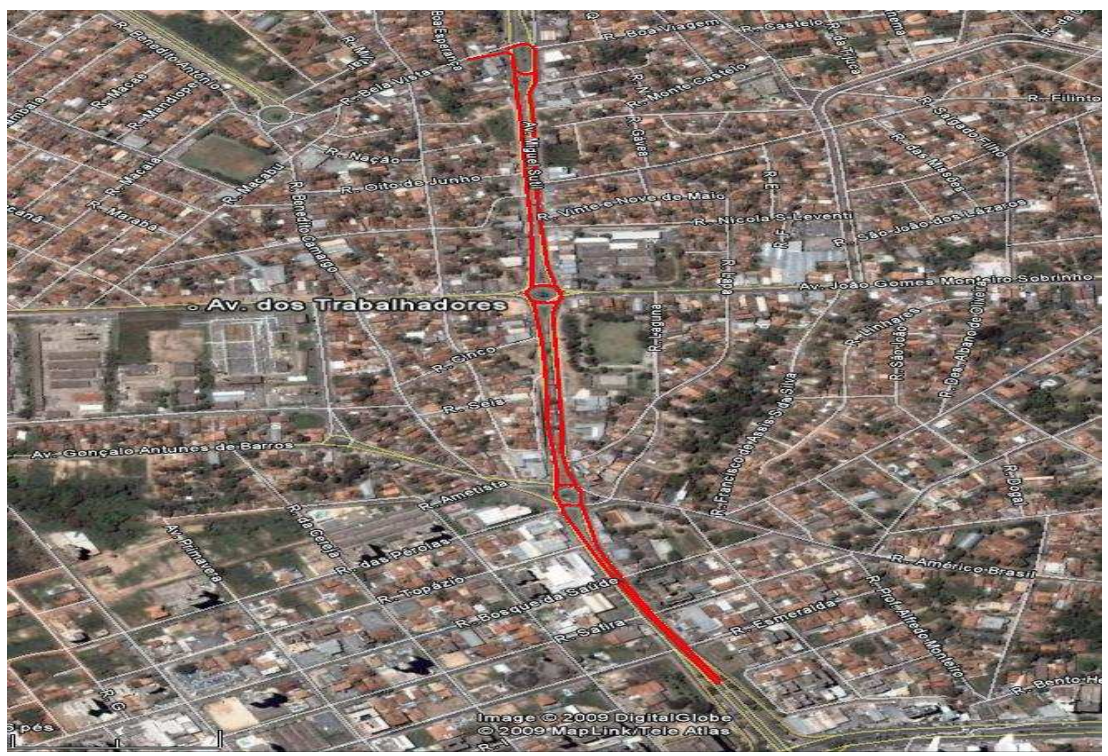

Figura 36 - Construção de trincheiras no complexo da Av. Miguel Sutil Fonte: Plano Setorial de Mobilidade Urbana de Cuiabá (SMTU)

13) Conclusão da estrada do Coxipó, ligação entre a Av. Dante de Oliveira (Antiga trabalhadores- Planalto) e a Av. das Palmeiras (Belvedere).

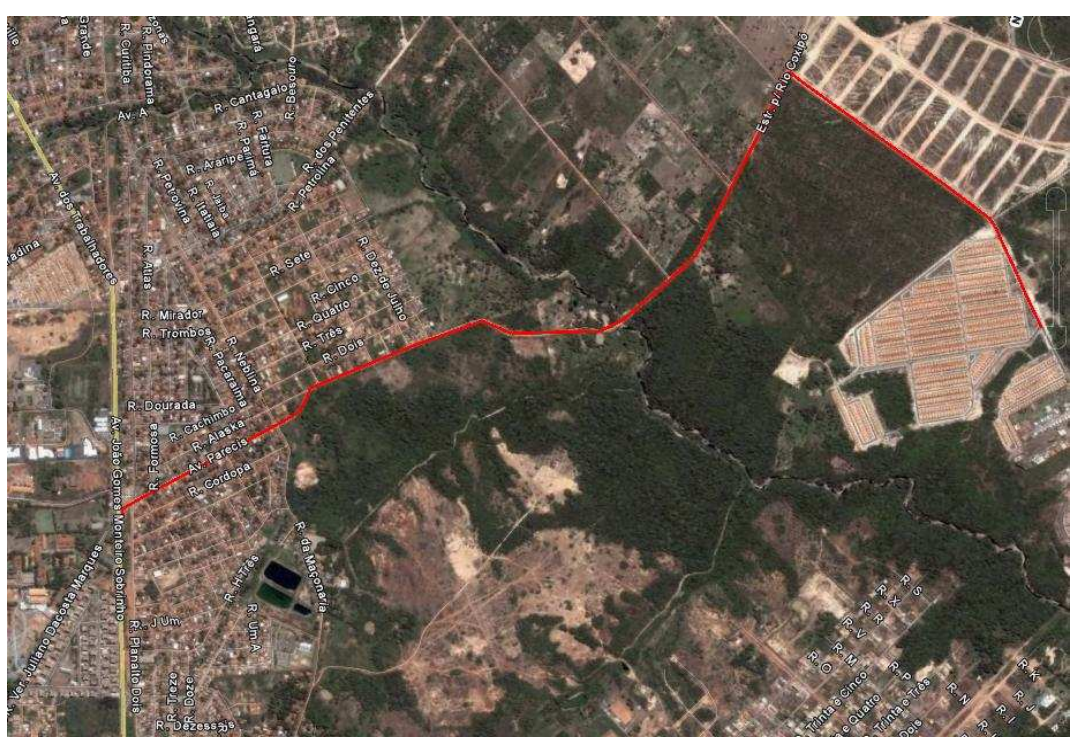

Figura 37 - Conclusão da estrada do Coxipó

Fonte: Plano Setorial de Mobilidade Urbana de Cuiabá (SMTU)

14) Prolongamento da Av. Hélio Ponce de Arruda (INPE), compreendido entre a rodovia Emanuel Pinheiro e a Av. do CPA na altura do trevo do IBAMA e (interligando com a Av. Parque Gumitá). 
15) Binário das avenidas Dante de Oliveira (antiga trabalhadores ) e Gonçalo Antunes de Barros (gráfica atalaia), trecho compreendido entre as Avenidas Miguel Sutil e das Torres.

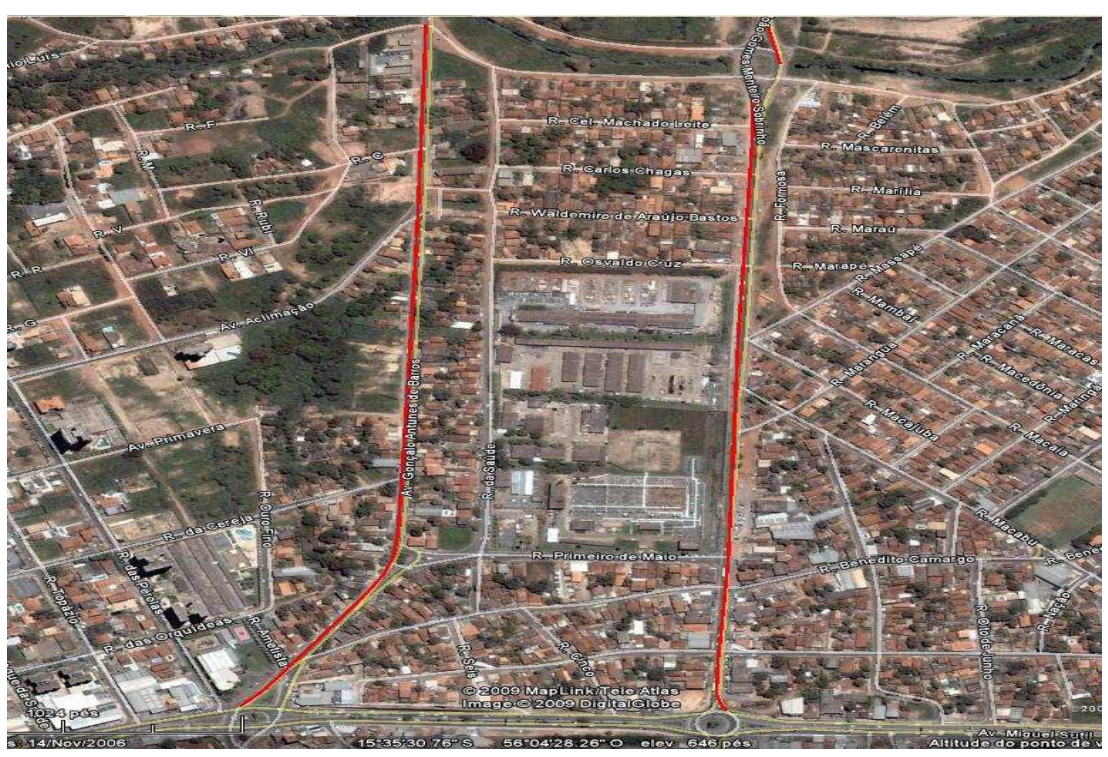

Figura 38 - Binário das avenidas Trabalhadores e Gonçalo Antunes Fonte: Plano Setorial de Mobilidade Urbana de Cuiabá (SMTU)

16) Passagem inferior na Av. Fernando Corrêa da Costa (lateral ao edifício vitória regia, inicio da Fernando Correa, Córrego do Gambá), interligando os bairros Jd. Guanabara e Poção.

17) Construção da Av. Beira Rio Norte, trecho entre a Av. Miguel Sutil, iniciando na cabeceira da ponte nova, percorrendo os fundos dos bairros Coophamil, Novo Terceiro e Cidade Verde, ligando se a Rodovia Ciríaco Cândia-Mário Andreazza.

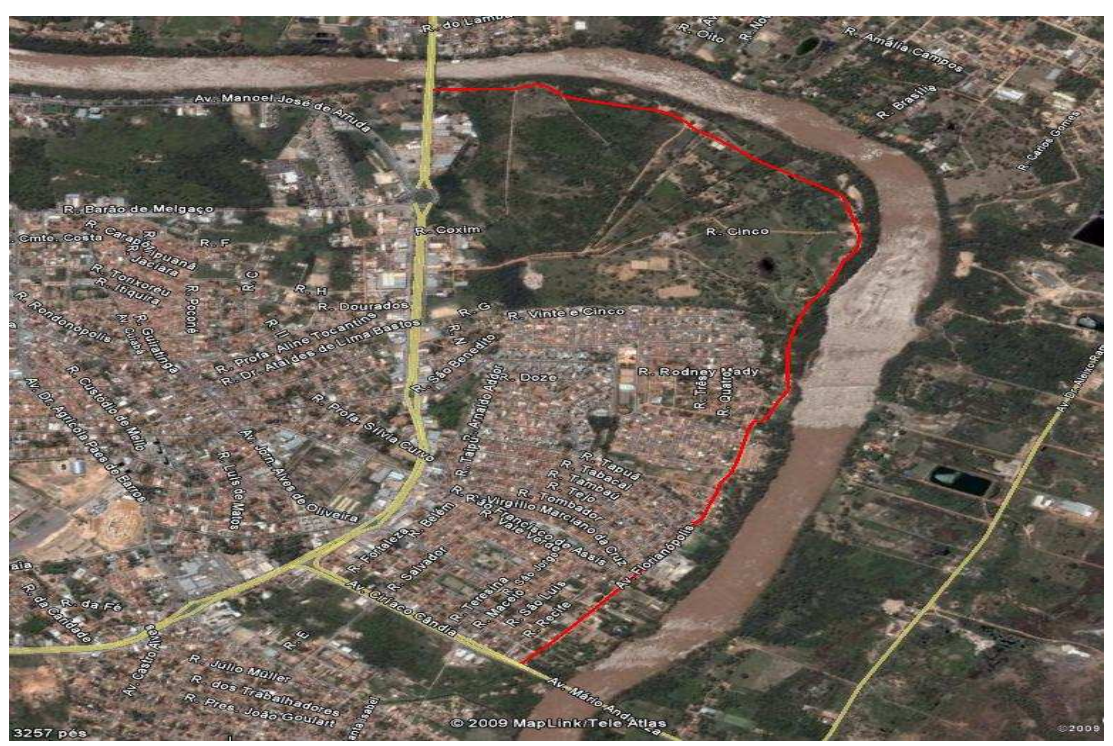


Figura 39 - Construção da Av. Beira Rio Norte

Fonte: Plano Setorial de Mobilidade Urbana de Cuiabá (SMTU)

18) Construção da Av. Oeste, trecho entre a BR 364 (Estância 21) e a Rodovia Palmiro Paes de Barros (Cemitério do Parque Cuiabá), acompanhando o "linhão".

19) Revitalização e implantação de sistema binário da Av. Dr. Meireles (Tijucal),adequações na rua dez e rua palmeiras brancas, trecho entre o Trevo do Tijucal e entrada do bairro São João Del Rei.

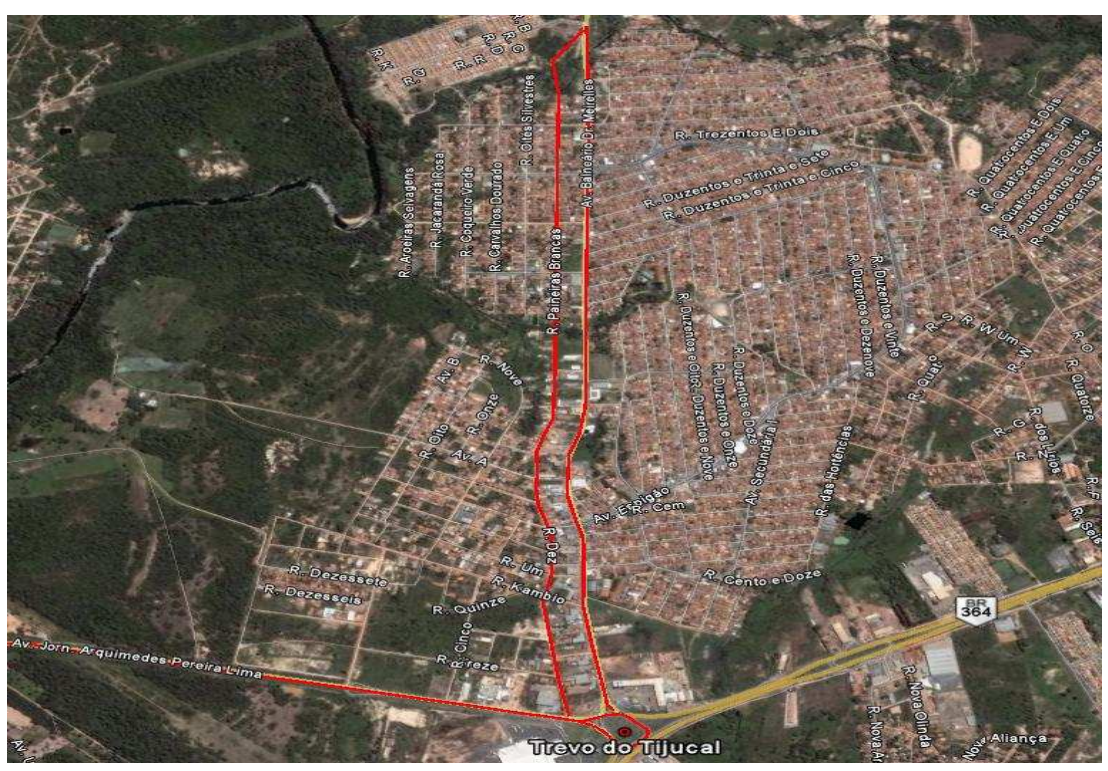

Figura 40 - Binário do B. Tijucal

Fonte: Plano Setorial de Mobilidade Urbana de Cuiabá (SMTU)

20) Pavimentação do bairro Pedra 90.

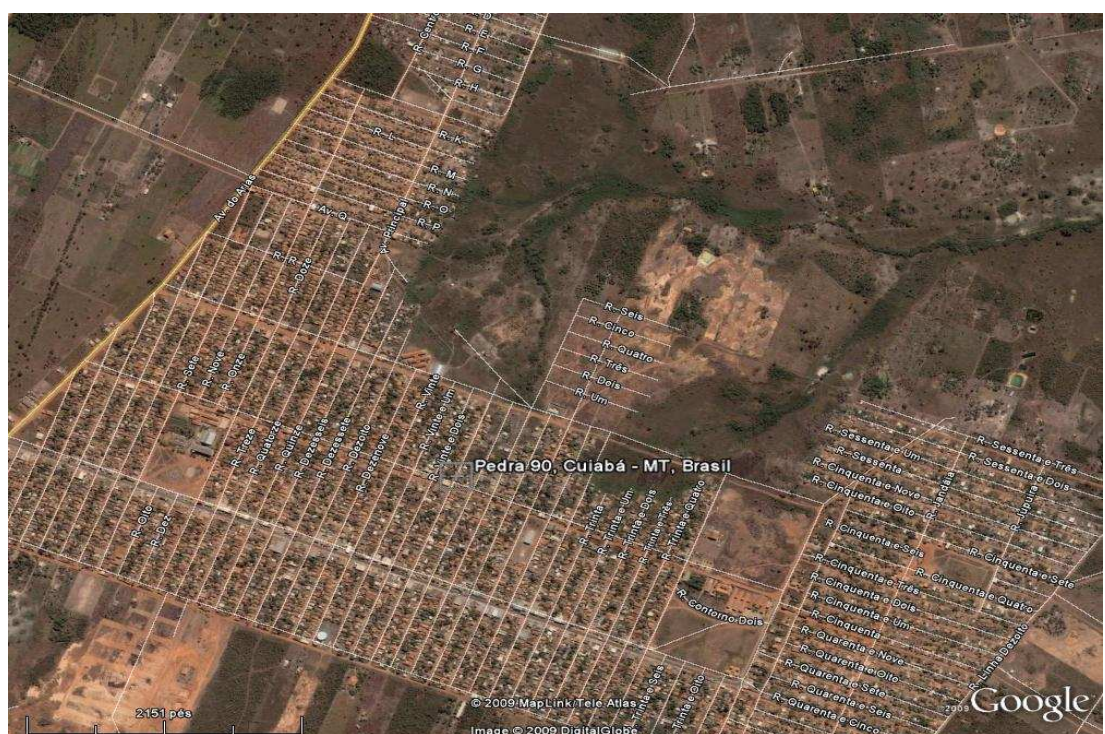

Figura 41 - Pavimentação B. Pedra 90

Fonte: Plano Setorial de Mobilidade Urbana de Cuiabá (SMTU) 


\section{OUTROS}

21) Cruzamento Rua Santa Terezinha x Tenente Lira,construção de rotatória, em frente a escola Luzes do Saber.

22) Cruzamento Av. General Melo x Trav. Celso Luiz Moraes de Almeida, construção de rotatória, entrada de acesso a governança.

23) Cruzamento da travessa Celso Luiz M. De Almeida (Av. córrego do gambá, governança) com Av. Fernando Correa da Costa, construção de viaduto, na lateral do edifício Vitória Régia.

24) Cruzamento com Av. Prof. João Gomes M. Sobrinho, construção de rotatória (em frente ao Ginásio da Lixeira).

25) Ligação (continuação) da Av. Beira Rio, iniciando próximo a empresa Matel, lado direito sentido Centro Coxipó até a Rodovia Palmiro Paes de Barros, estrada de Sto. Antônio de Leverger, acessando o trevo da Cohab São Gonçalo.

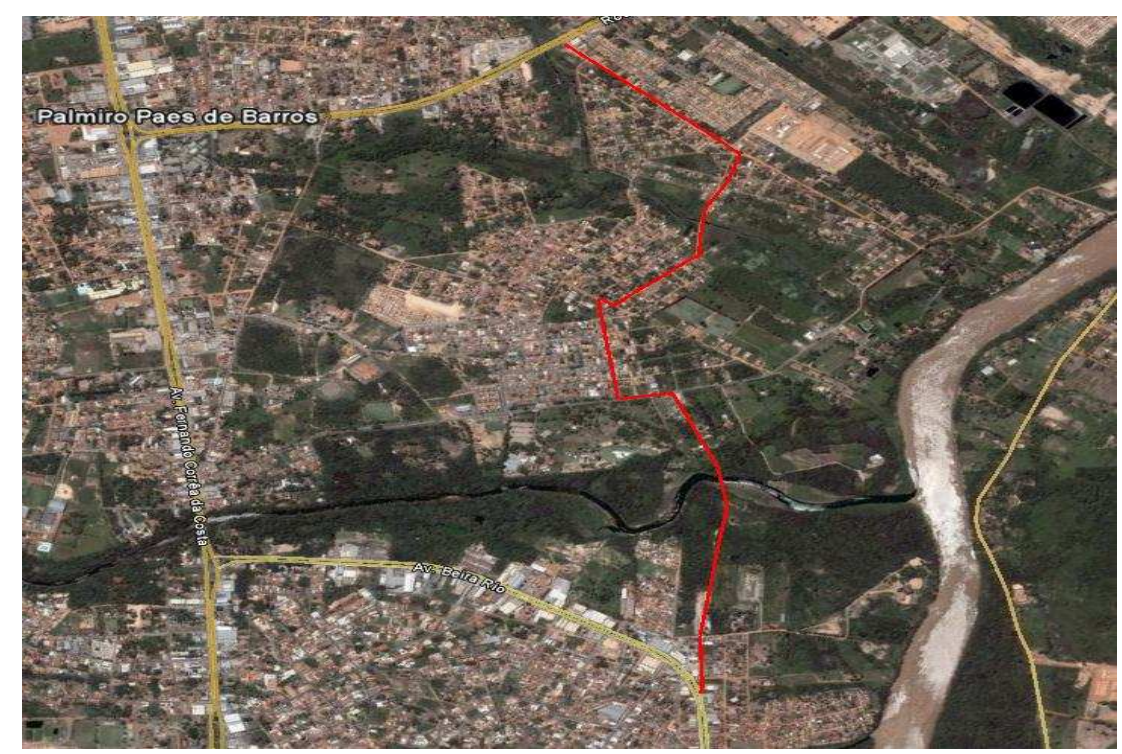

Figura 42 - Av. Beira Rio até a Av. Palmiro Paes de Barros Fonte: Plano Setorial de Mobilidade Urbana de Cuiabá (SMTU e IPDU)

26) Cruzamento da Av. Beira-Rio e a Av. Gal. Mello construção de rotatória.

27) Construção de Ponte sobre o rio Coxipó - na ligação (Continuação) da Av. Beira-Rio, até a rua Antônio Dorileo ( São Gonçalo Beira Rio). 


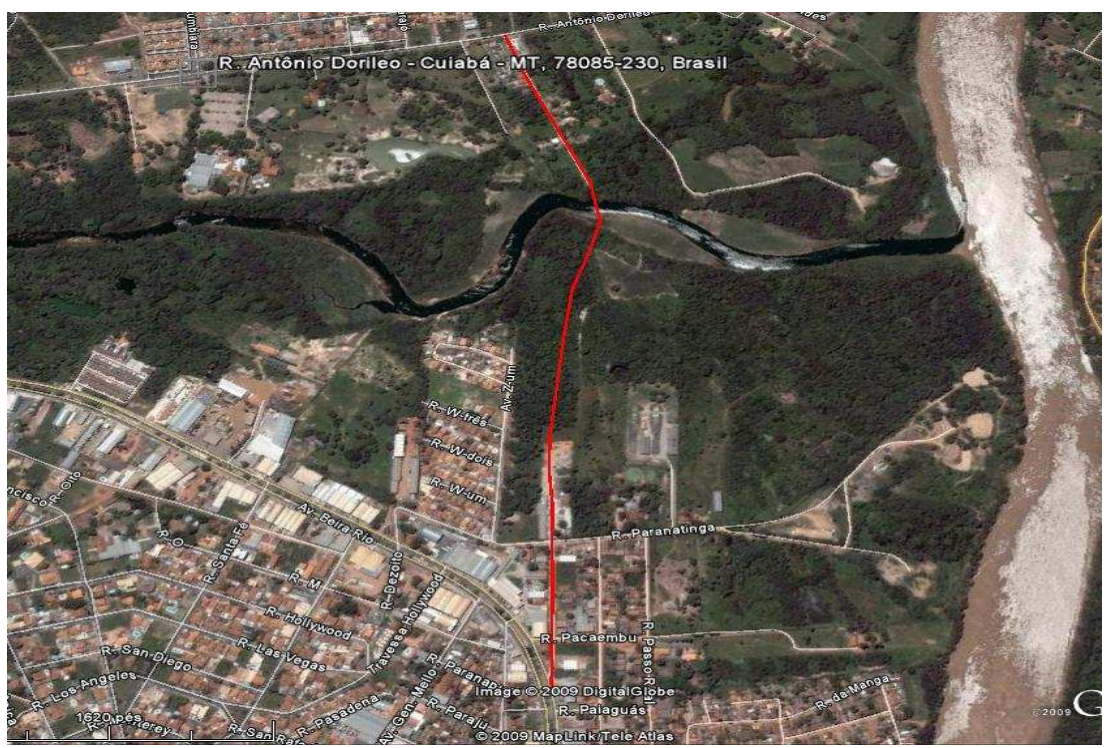

Figura 43 - Construção de Ponte sobre o rio Coxipó

Fonte: Plano Setorial de Mobilidade Urbana de Cuiabá (SMTU)

28) Cruzamento da (continuação) Av. beira Rio com a rua Antônio Dorileo, (São Gonçalo Beira Rio).

29) Cruzamento da Av. M. Sutil e Av. Carmindo de Campos const. de rotatória.

30) Duplicação do trecho entre a Av. Gal. Mello até a beira rio, e Av. Gov. José Fragelli até a Av. Carmindo de Campos.

31) Cruzamento Carmindo de Campos com Av. Gov. José Fragelli const. de rotatória.

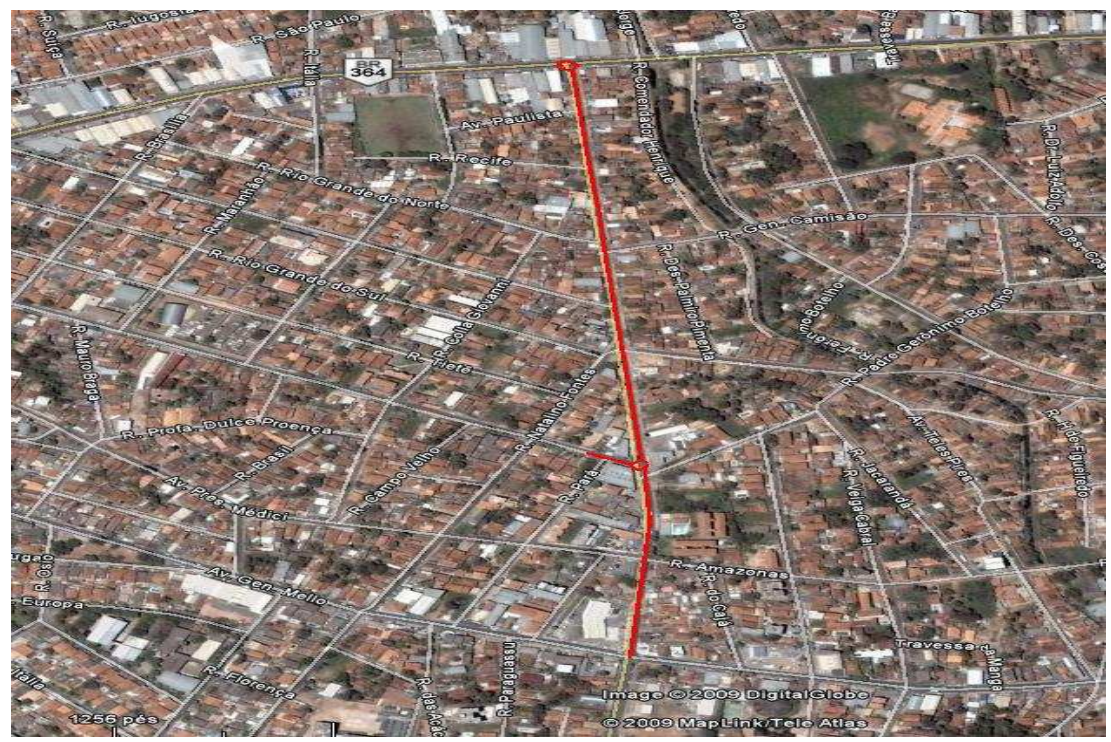

Figura 44 - Rotatória do Cruzamento da Av. Miguel Sutil com Av. C. de Campos Fonte: Plano Setorial de Mobilidade Urbana de Cuiabá (SMTU) 
32) Continuação da Av. Gal. Ramiro de Noronha até a Rua Miguel Seror, no bairro Sta. Rosa, construção de rotatória no cruzando da Miguel Sutil, paralelo a Soma veículos.

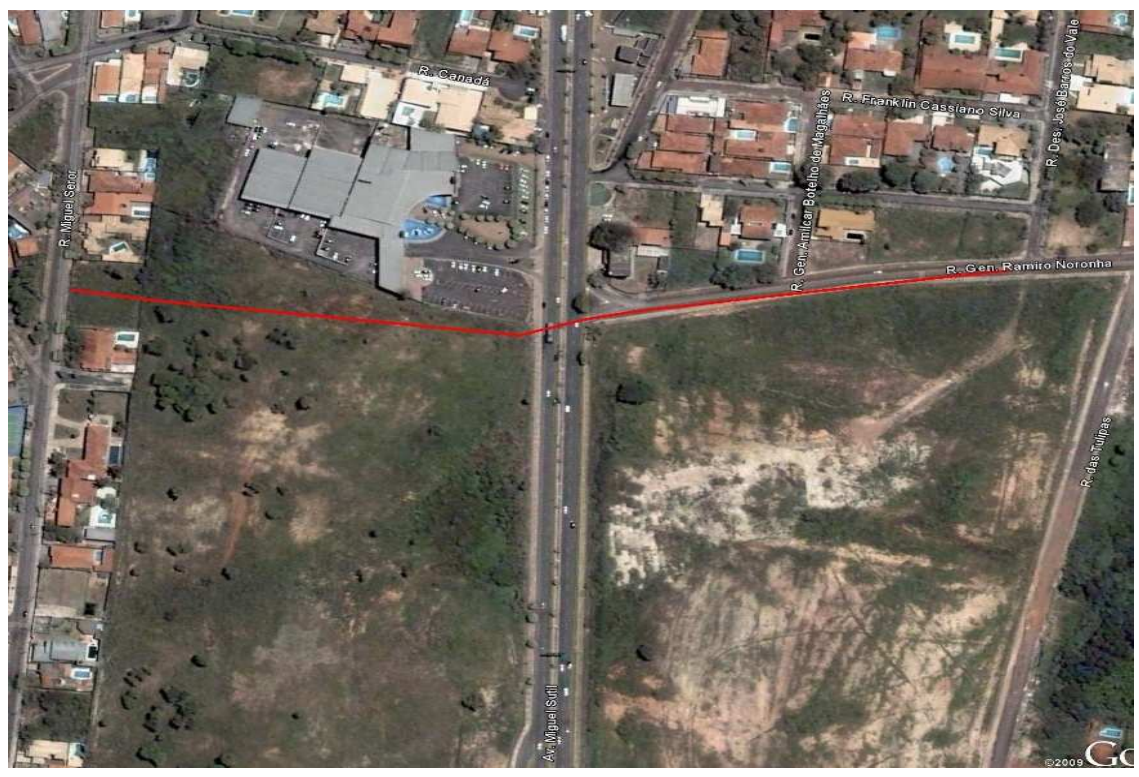

Figura 45 - Rotatória e Prolongamento da R. Ramiro de Noronha até a R. M. Seror. Fonte: Plano Setorial de Mobilidade Urbana de Cuiabá (SMTU)

33) Criação da Av. Parque Gumitá, iniciando na Av. Hist. R. de Mendonça (Av. CPA), próximo a associação dos delegados (ANDEPOL), lado direito, sentido centro bairro, cruzando pelas avenidas Vic. E. Vuolo e Dante M. de Oliveira (Trabalhadores), até a Av. Arquimedes P. Lima (estrada do moinho).

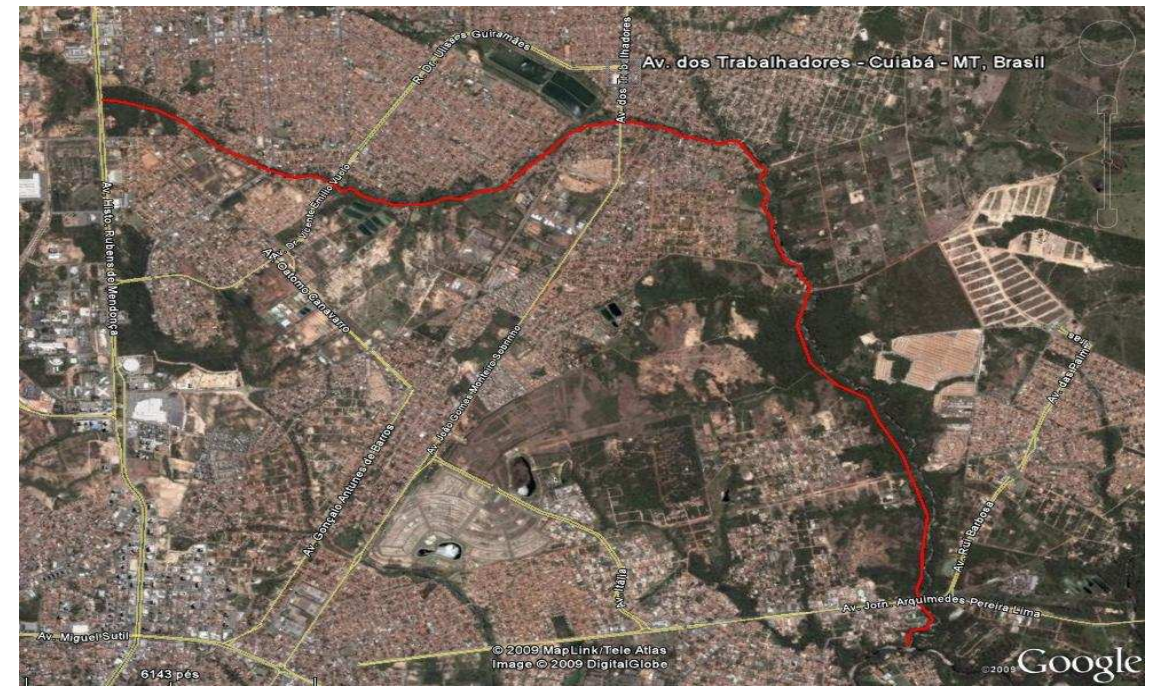

Figura 46 - Av. Parque Gumitá

Fonte: Plano Setorial de Mobilidade Urbana de Cuiabá (SMTU) 
34) Construção do Viaduto sobre Av. Fernando Corrêa (Shopping 3 Américas), no Cruzamento da Av. Brasília com a Av. Tancredo Neves.

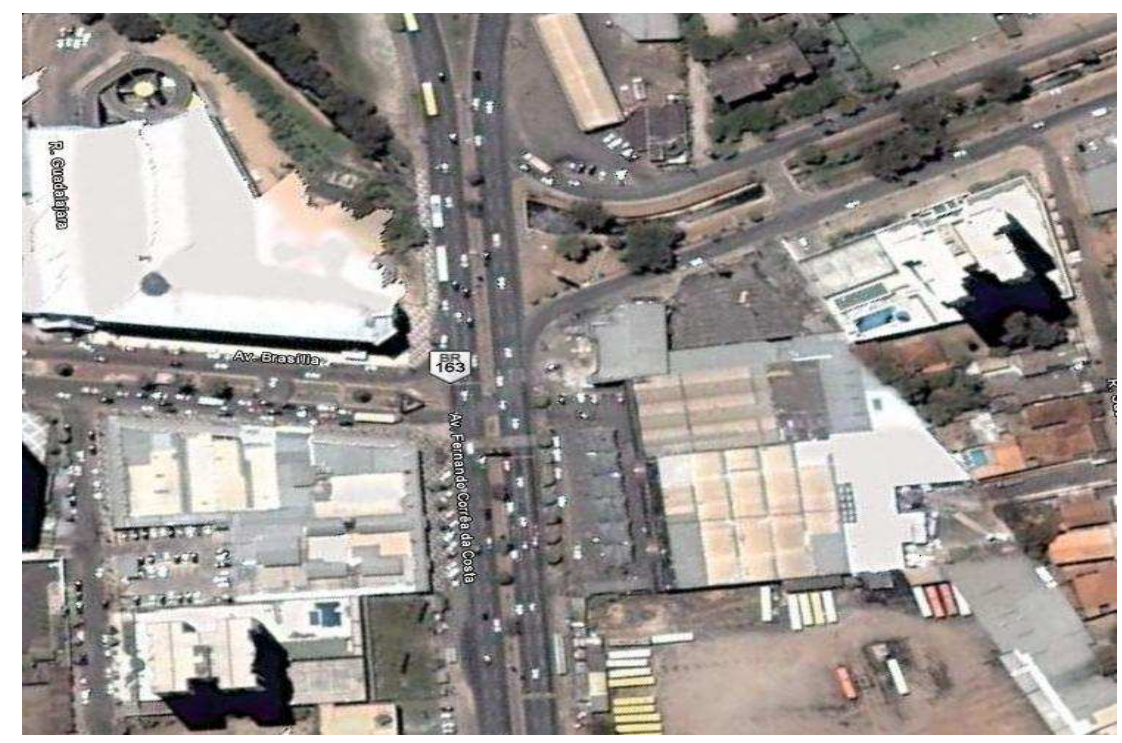

Figura 47 - Viaduto sobre a Av. Fernando Corrêa (Shopping 3 Américas) Fonte: Plano Setorial de Mobilidade Urbana de Cuiabá (SMTU)

35) Ligação com Av. do CPA, na altura da associação dos delegados de policia.

36) Duplicação da Avenida Dante de Oliveira, trecho compreendido entre o final da Av. Juliano Costa Marquês (policlínica do planalto) e a ligação para o bairro Altos da Serra (acompanhando o linhão).

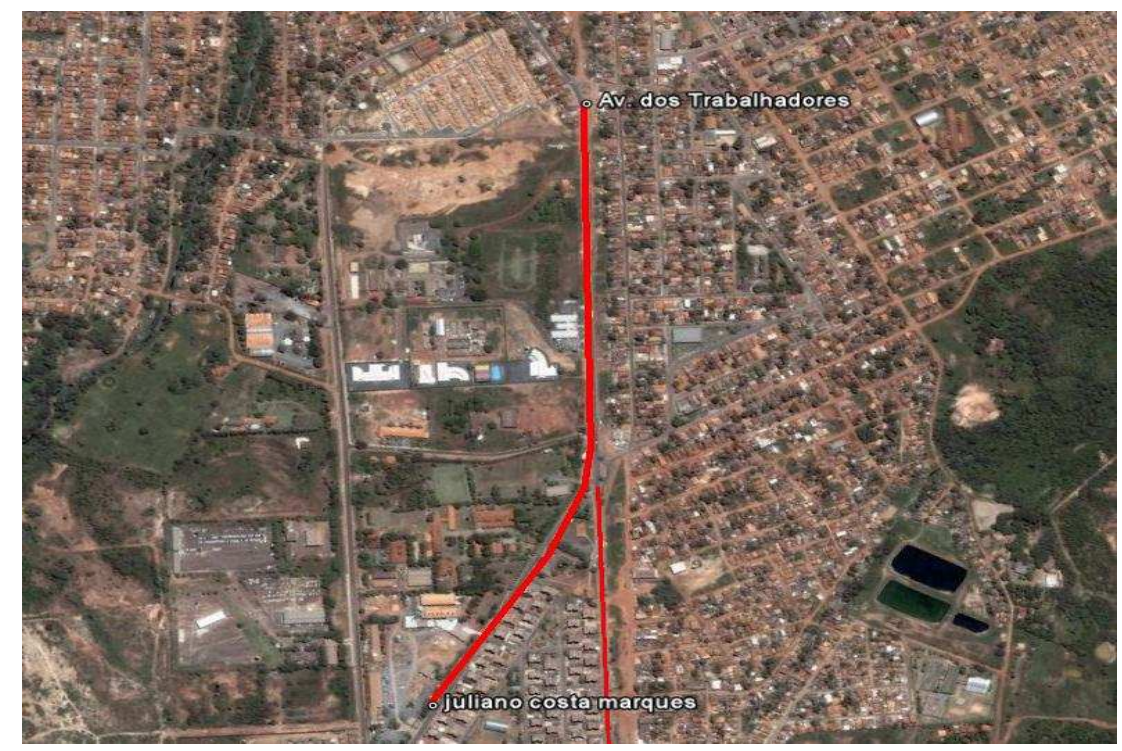

Figura 48 - Duplicação Av. Dante de Oliveira Fonte: Plano Setorial de Mobilidade Urbana de Cuiabá (SMTU) 
37) Ligação da Av. Érico Preza(Av. Itália), pelo bairro Carumbé, à Av. Juliano Costa Marques, próximo ao trevo nos fundos do Shopping Pantanal.

38) Ligação com a Av. Aclimação.

39) Cruzamento com a Rua Ênio Carlos de Souza Vieira) VIADUTO, rua de acesso pela Av. do CPA ao canal 8.

40) Ligação da Av. Fernando Corrêa da Costa (trevo da EMEB Maria Dimpina) até a Av. Archimedes Pereira Lima (Trevo da Brahma), passando pelo bairro Chácara dos Pinheiros, subindo o Córrego do Moinho até chegar a Av. Parque Gumitá.

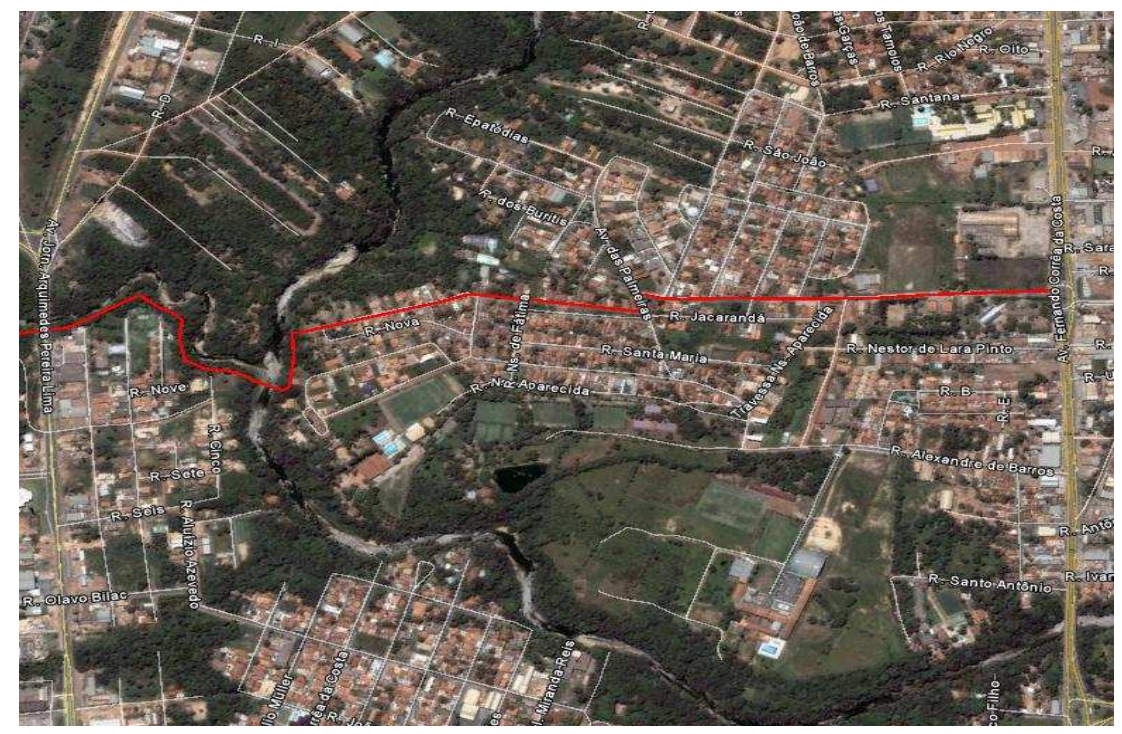

Figura 49 - Ligação da Av. Fernando Corrêa da Costa até a Av. Archimedes Lima Fonte: Plano Setorial de Mobilidade Urbana de Cuiabá (SMTU)

41) Criação de binário entre a Av. Carmindo de Campos e a Rua das Mangueiras, ligando a Carmindo até a Av. das Torres.

42) Binário compreendendo as ruas (Saionara e Lua Morena) e a Rua 60 (9 BEC, Baretta VIP), ligando a Avenida Fernando Corrêa da Costa a Avenida das Torres.

43) Ligação Av. Mato Grosso com Av. Miguel Sutil (Via Av. São Sebastião / Afonso Pena) IPDU/SMTU.

44) Adequação da rotatória da Av. das Flores com Miguel Sutil, Círculo Militar. Otimizando ligação da Av. 08 de Abril com Senador Metelo / adequação da Ponte Nova à Av. 08 de abril, via Av. Beira Rio, antes da Rotatória da Miguel Sutil.

45) Centro Histórico - Rebaixamento da fiação e substituição do calçamento da área tombada e entorno. 
46) Duplicação da BR 364, entre, o Elevado do Distrito Industrial ao Rodoanel e interligação em pista dupla entre a BR 364 a Avenida das Torres.

47) Prolongamento da Avenida das Torres até o Rodoanel.

48) Duplicação da MT 010, Helder Cândia (estrada da Guia), trecho compreendido entre a rotatória da MT 251, Emanuel Pinheiro( estrada da Chapada), até o Rodoanel.

49) Ligação entre os bairros Despraiado e Jd. Ubirajara, com passagem de nível na MT 010 (estrada da Guia), próximo a rotatória com a estrada da Chapada.

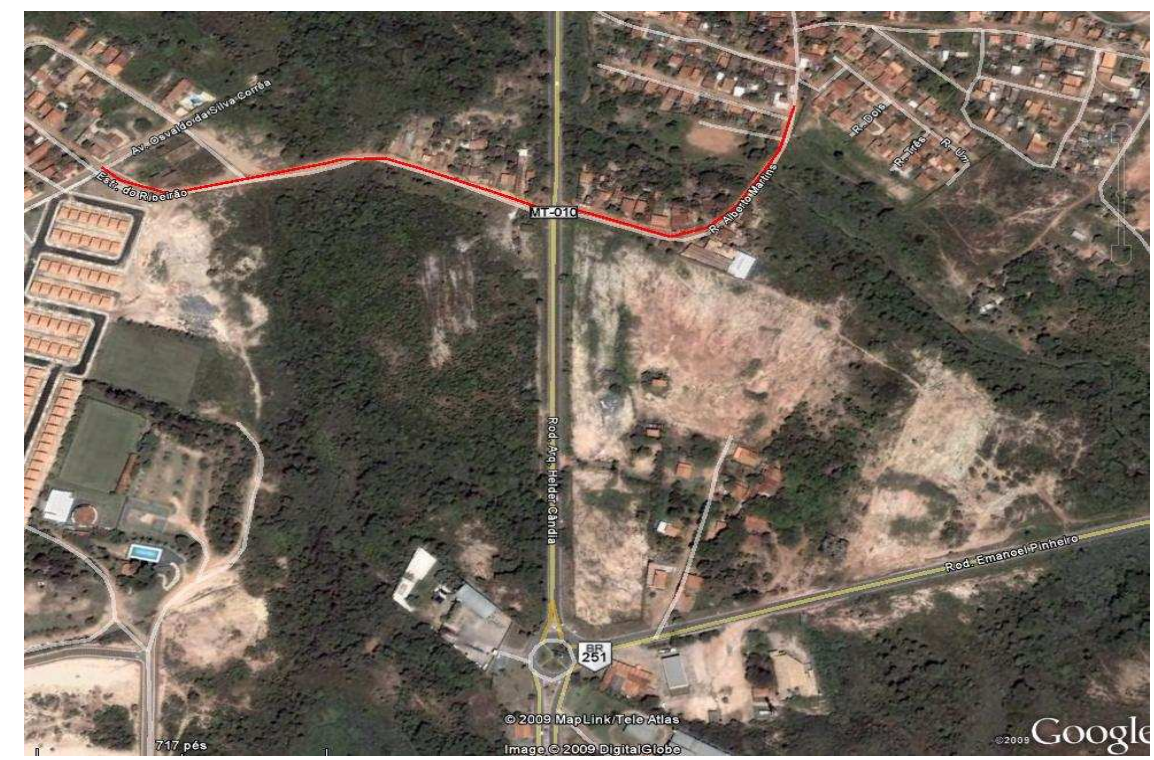

Figura 50 - Ligação entre os bairros Despraiado e Jd. Ubirajara Fonte: Plano Setorial de Mobilidade Urbana de Cuiabá (SMTU)

50) Ligação em binário entre as Avenidas Miguel Sutil próximo ao ICEC, República do Líbano, bairro Despraiado.

51) Implantação de binário na Ligação da Av.Historiador R. de Mendonça a Rod. 251, Emanuel Pinheiro, pela Av. Coronel Torquato (principal do Novo Paraíso), e a sua paralela a Av. B, com sua complementação e pavimentação. Trecho entre a lateral do Comando Geral e a Fundação Bradesco. 


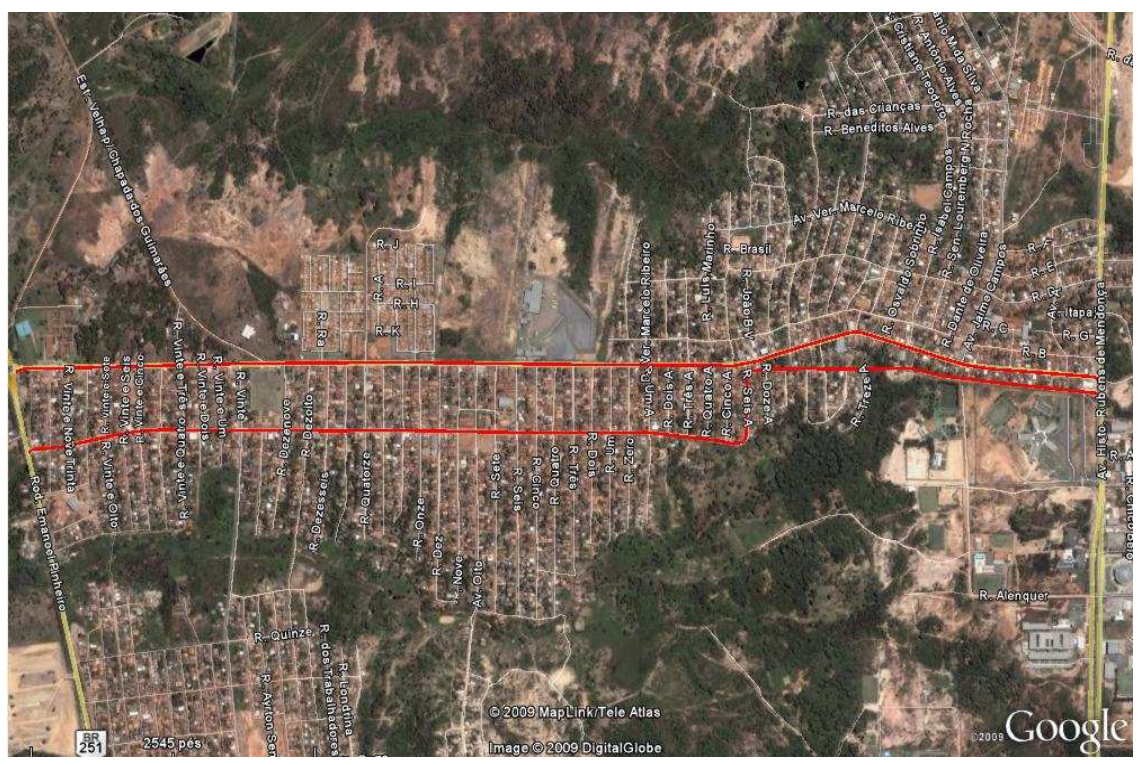

Figura 51 - Binário na Ligação da Av. R. de Mendonça a Rod. 251 Fonte: Plano Setorial de Mobilidade Urbana de Cuiabá (SMTU)

52) Duplicação da Av. Antártica no trecho compreendido entre a ponte, (final do bairro Sta. Rosa) até o Rodoanel.

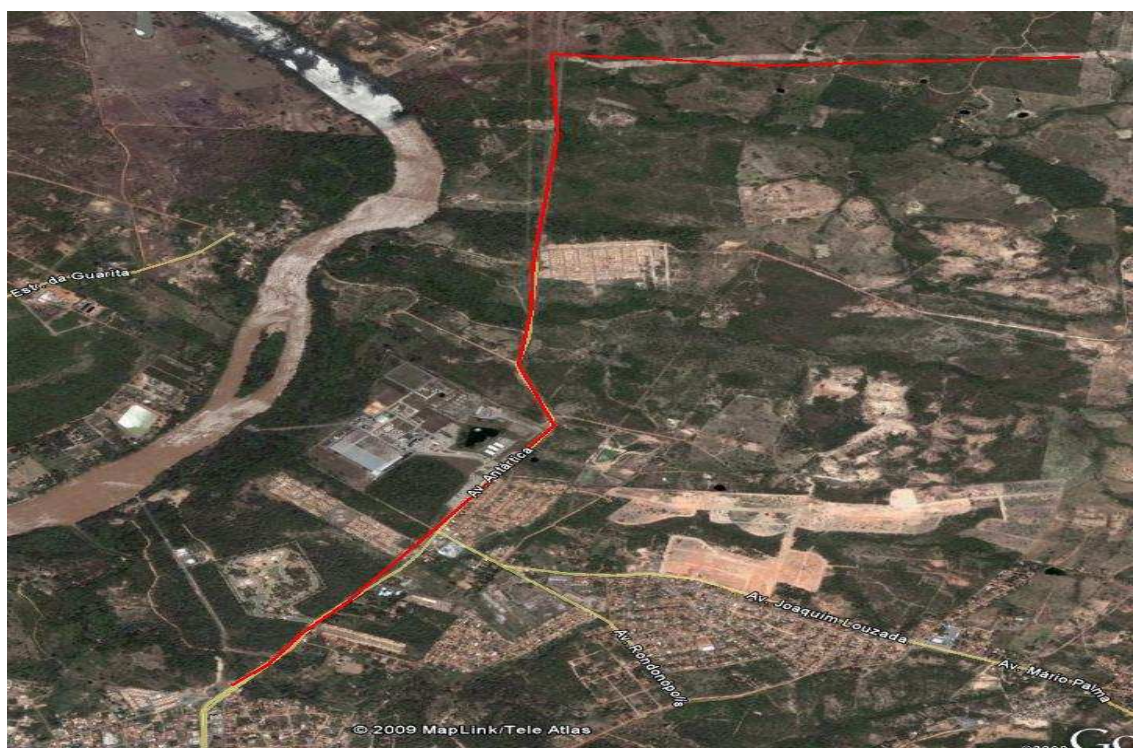

Figura 52 - Duplicação da Av. Antártica até o Rodoanel Fonte: Plano Setorial de Mobilidade Urbana de Cuiabá (SMTU)

53) Duplicação da Avenida Rubens de Mendonça, trecho compreendido entre a Rua Osasco (ginásio Verdinho) até o Rodoanel.

54) Prolongamento da Avenida Brasil (principal do CPA II), até associação beneficente Vantuil de Freitas no bairro $1^{\circ}$ de março. 


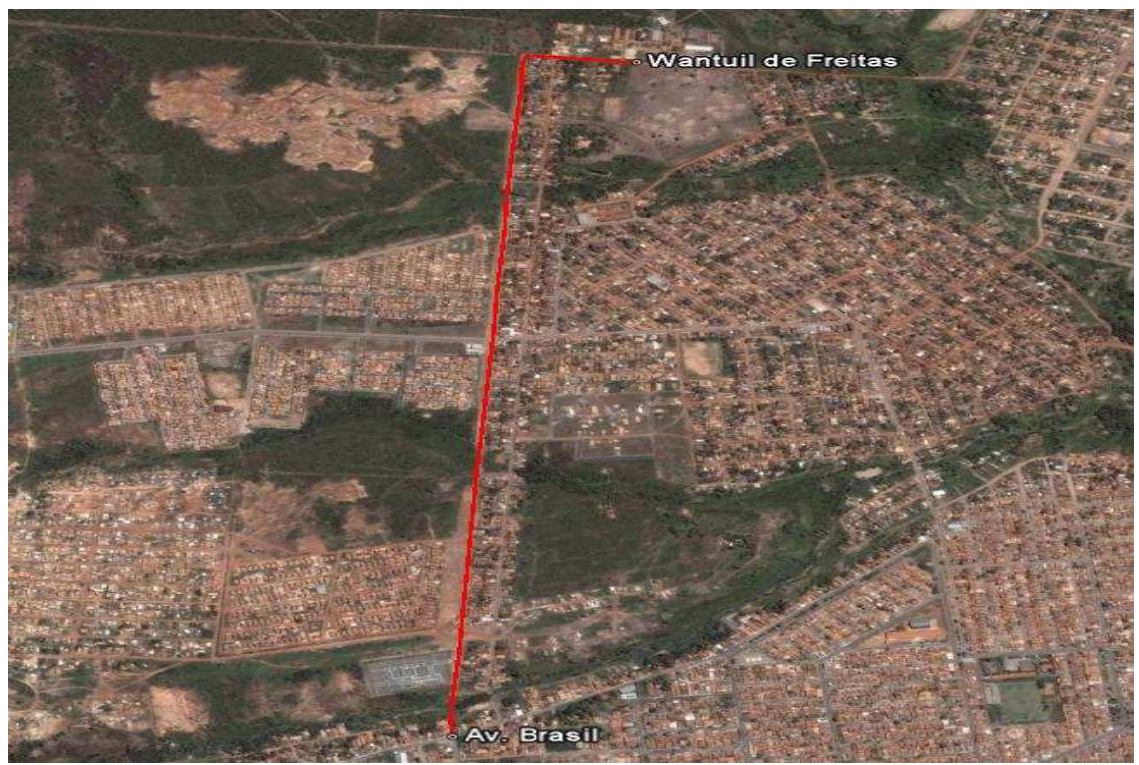

Figura 53 - Prolongamento da Avenida Brasil até bairro $1^{\circ}$ de Março Fonte: Plano Setorial de Mobilidade Urbana de Cuiabá (SMTU)

55) Tratamento em rotatória do cruzamento entre a Av. General Melo e Av. Carmindo de Campos (Posto Tropical).

56) Tratamento de conflito no cruzamento da Rua General Melo com a Avenida Tancredo Neves.

57) Conclusão da Rua Itaparica, iniciando no final da ponte do coxipó sentido centro bairro, bifurcação, (com pavimentação a partir da sua metade, até a Rodovia Palmiro Paes de Barros, próximo ao trevo do bairro Nossa Senhora Aparecida).

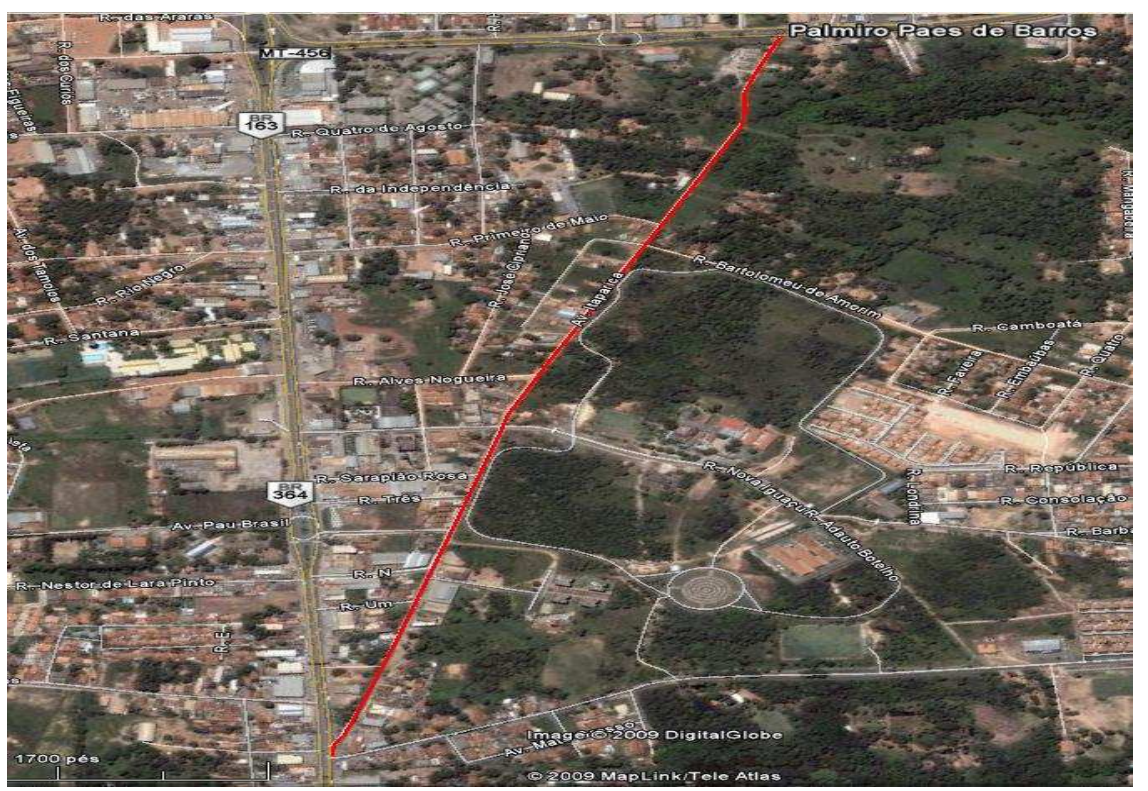

Figura 54 - Conclusão da Rua Itaparica

Fonte: Plano Setorial de Mobilidade Urbana de Cuiabá (SMTU) 
59) Complementação do projeto Avenida Parque Gumitá.

59) Tratamento de conflitos ao longo da Avenida 08 de Abril,entre a rua Brig. Eduardo Gomes próximo a praça do bairro Popular, passando pelos bairros Goiabeiras, Jardim Cuiabá, J. Independência, J. Primavera, Porto, terminado na Rua 13 de Junho.

60)Tratamento de conflito na Avenida Miguel Sutil (construção de viaduto), no cruzamento com a Rua Afonso Pena, entrada do bairro Despraiado.

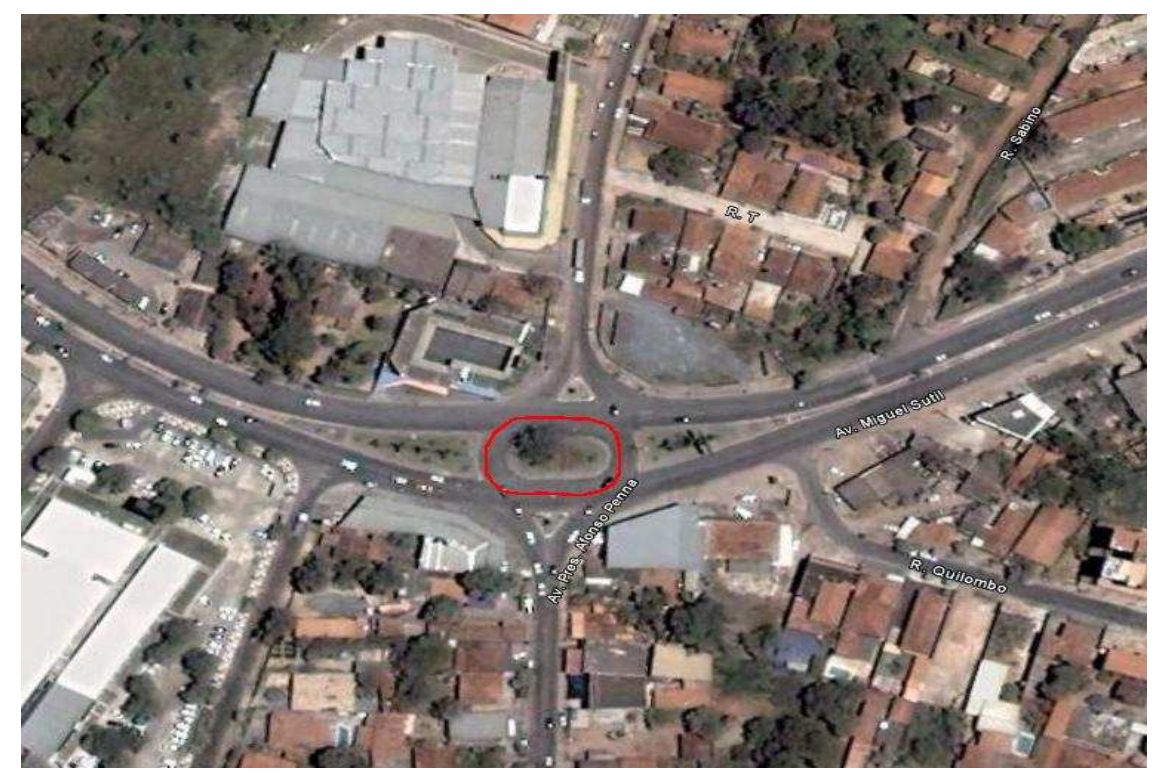

Figura 55 - Av. Miguel Sutil com R. Afonso Pena (construção de viaduto) Fonte: Plano Setorial de Mobilidade Urbana de Cuiabá (SMTU)

61) Pavimentação das ruas Armando Candia, lateral do modelo Miguel Sutil, e Tereza Lobo, fazendo a ligação entre as Avenidas Miguel Sutil e República do Líbano próximo Jornal Folha do Estado (bairro Consil). 


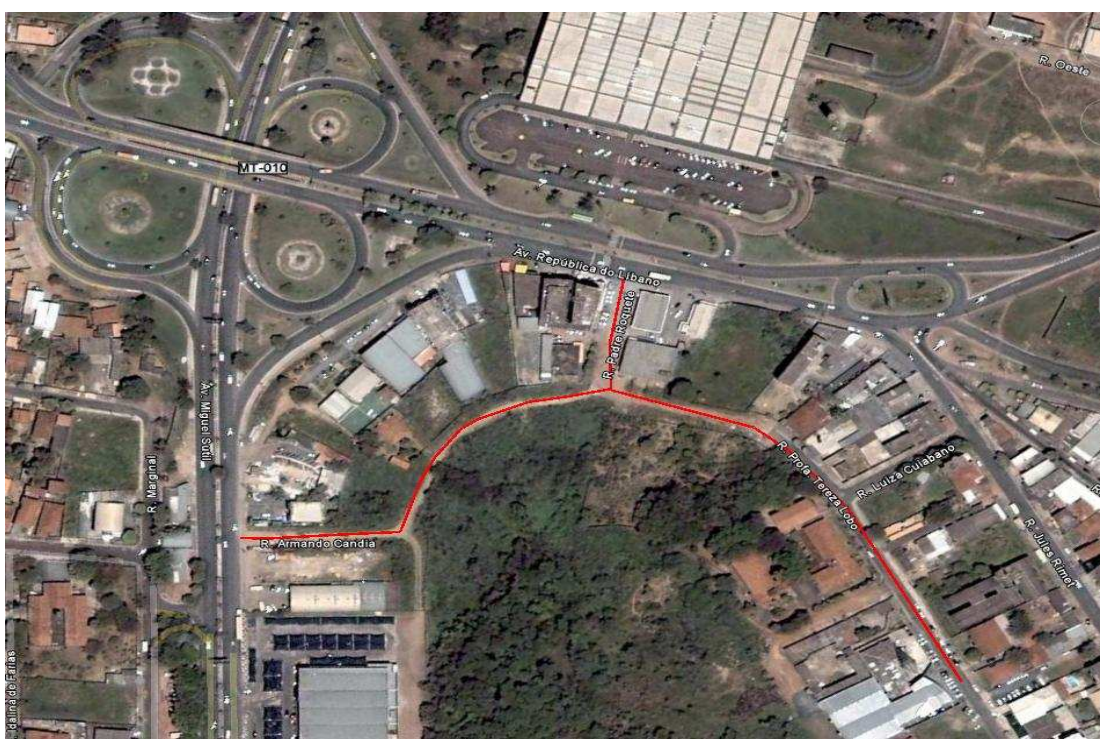

Figura 56 - Pavimentação das ruas Armando Candia, e Tereza Lobo Fonte: Plano Setorial de Mobilidade Urbana de Cuiabá (SMTU)

62) Ligação entre os bairros Alto da Boa Vista e Senhor dos Passos, iniciando próximo ao ICEC, rua Afonso Pena,indo até aos fundos da rodoviária.

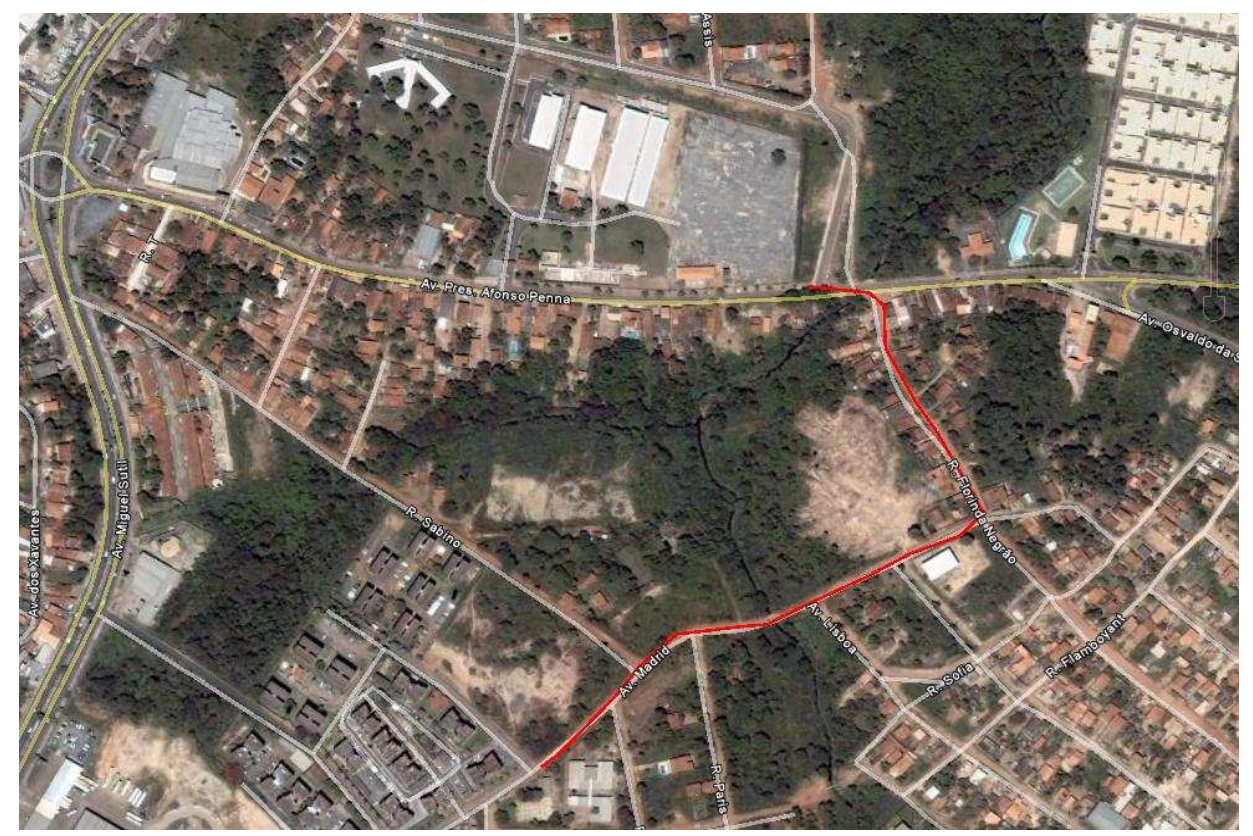

Figura 57 - Ligação entre os bairros Alto da Boa Vista e Senhor dos Passos Fonte: Plano Setorial de Mobilidade Urbana de Cuiabá (SMTU)

63) Interligação do complexo turístico do Coxipó do Ouro,via ponte de ferro e rodovia Emanuel Pinheiro Itens:64,65,66, subseqüentes.

64) Ligação do bairro Novo Paraíso ao Coxipó do Ouro, via Usina de Com postagem. 
65) Ligação da MT 251 (Rodovia Emanuel Pinheiro) ao entroncamento do Coxipó do Ouro.

66) Ligação em pavimentação do Coxipó do Ouro via Ponte de Ferro.

67) Pavimentação da Estrada Velha da Guia, iniciando no Sucuri e terminando na cabeceira da ponte da atual estrada da Guia MT 010, próximo a rotatória com a Emanuel Pinheiro.

68) Pavimentação da estrada do Ribeirão Ligando a Av. Afonso Pena(Despraiado), final da mesma, a MT 010 (estrada da Guia).

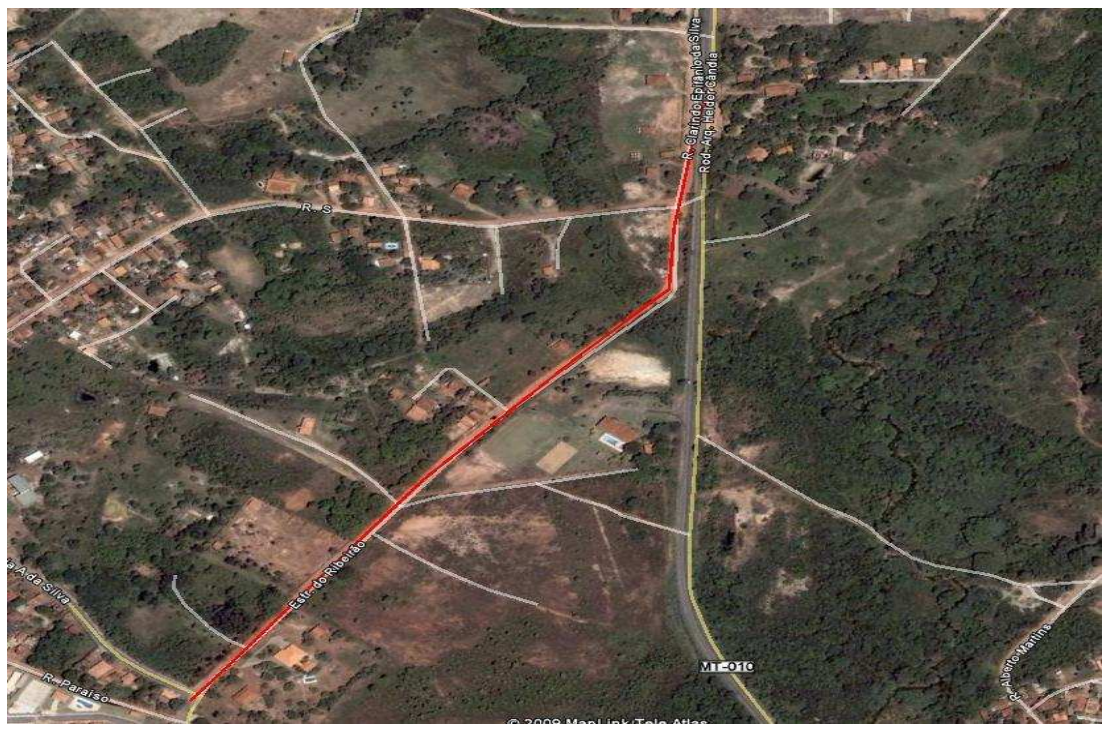

Figura 58 - Pavimentação da estrada do Ribeirão Ligando a Av. Afonso Pena Fonte: Plano Setorial de Mobilidade Urbana de Cuiabá (SMTU)

69) Complementação da Avenida Mário Palma, ligação entre os bairros Jardim Mariana e Novo Colorado. 


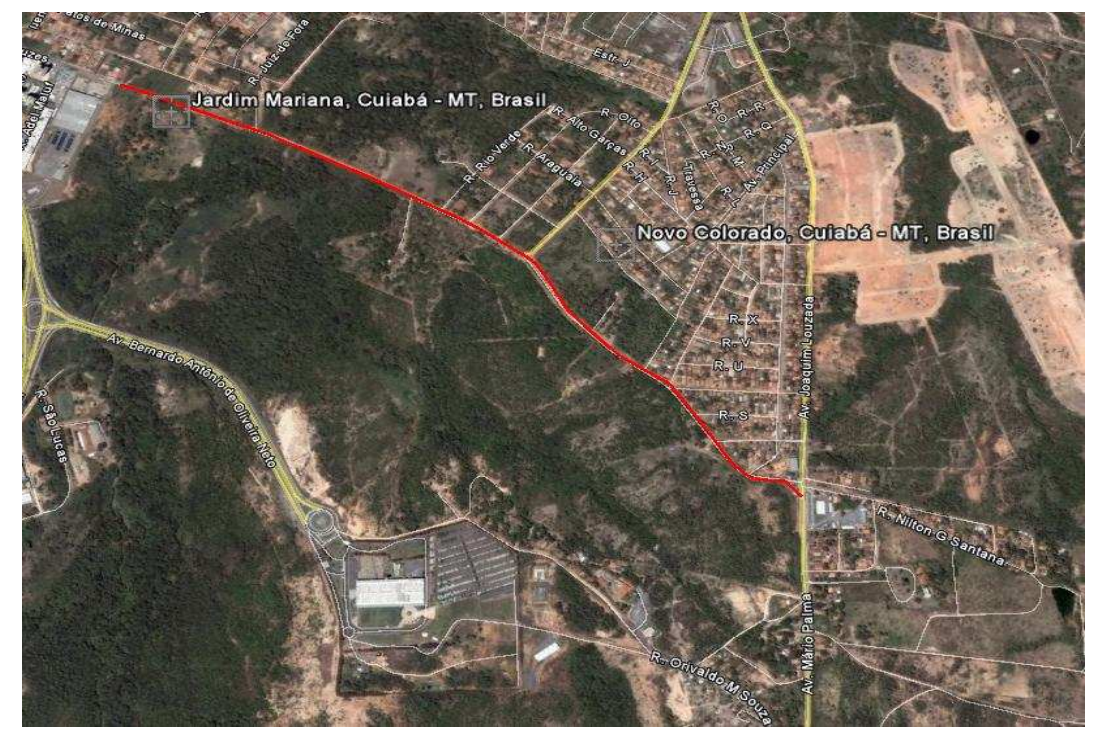

Figura 59 - Complementação da Avenida Mário Palma

Fonte: Plano Setorial de Mobilidade Urbana de Cuiabá (SMTU)

70) Ligação da Rodovia Palmiro Paes de Barros (estrada de Sto. Antonio) ao Jardim Mossoró ,pavimentação das Ruas “A”, e "B” e duas transversais.

71) Ligação do Jardim Imperial II a Avenida das Torres,pavimentação da linha de ônibus.

72) Ligação da Avenida Rubens de Mendonça a Avenida Brasil, passando entre o Serra Dourada e o Residencial Ana Maria.

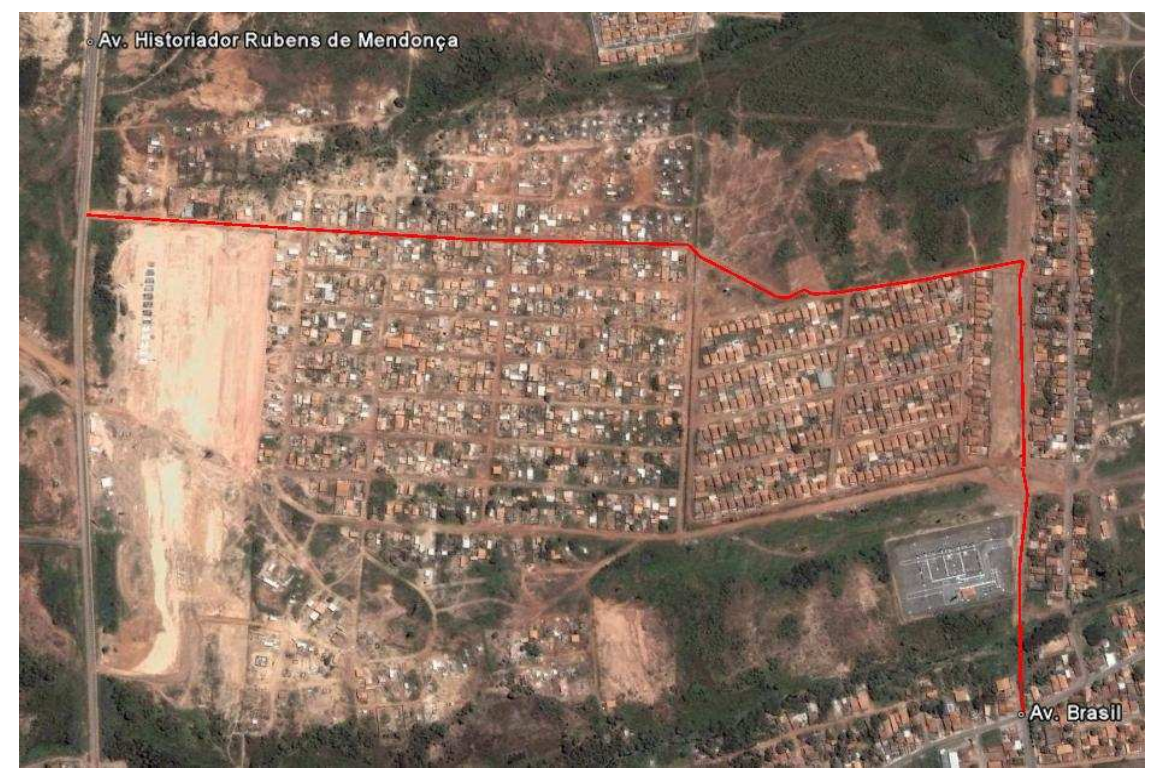

Figura 60 - Ligação da Avenida Rubens de Mendonça a Avenida Brasil Fonte: Plano Setorial de Mobilidade Urbana de Cuiabá (SMTU) 
O IPDU vem trabalhando em projetos para adequar algumas áreas, como a central, para acomodar os corredores e adaptar a cidade no que for preciso para receber as ações do Plano de Mobilidade. O Plano, em especial as intervenções físicas no sistema viário, estão de acordo com o que foi diagnosticado (onde as intervenções respondem a muitos dos problemas elencados) mas, lamentavelmente não foram previstas ações para as calçadas, nem para um sistema de ciclovias no município.

Poucas das ações propostas já são realidades. Entre as que já estão prontas encontra-se a maior parte da Avenida das Torres (porém sem iluminação e faltando a ponte sobre o Córrego do Moinho), a rotatória da Avenida Miguel Sutil que dá acesso para a Igreja Nossa Senhora de Guadalupe, e os terminais do CPA, e Coxipó.

Algumas questões ficam como pontos de interrogação: será que a retirada de parte da frota não causará maiores transtornos para a população, tendo em vista que esta já se encontra cansada de longas esperas, transbordos desconfortáveis e ônibus lotados? Será que os prazos das intervenções serão cumpridos, tendo em vista que não costumam ser, e as intervenções demoram a se concretizar? O que é prioridade? Como será avaliado? A população poderá acompanhar o processo de implantação e será chamada a participar e opinar?

Fica a expectativa de que o sistema quando implantado seja monitorado e que realmente o processo de planejamento do transporte e do transito (e do planejamento como um todo) não seja apenas um ponto, mas que seja contínuo.

Percebe-se que Cuiabá saiu na frente na elaboração do seu Plano de Mobilidade, tendo optado pelos corredores de ônibus. Várzea Grande ainda tem realizado ações emergenciais em pontos de conflito na cidade e não iniciou seu Plano de Mobilidade. Não se percebe no Plano de Cuiabá preocupação com a integração entre os municípios, porém os técnicos do setor de transporte e trânsito dizem que será pensado em comum, inclusive a nível metropolitano com a participação do Governo do Estado.

Não se conseguiu acesso às intervenções que estão sendo planejadas para a região central de Cuiabá, logo não se pode avaliar se estão contidas ações para a acessibilidade de portadores de necessidades especiais entre outras.

Por ser um setor que vem requerendo muita atenção devido a piora que as cidades experimentam no transito e no transporte com o aumento da frota de veículos, requer ações em curto e médio prazo, mas não é o que se tem visto, pois muitas das intervenções já eram apresentadas para a população - inclusive em campanhas políticas - a mais de dez anos e até hoje não se realizaram. Com um transporte público de má 
qualidade, a população busca o automóvel e as motocicletas, agravando o trafego intensamente.

Lamentavelmente nada tem sido feito para adequar as calçadas, e nem para proporcionar o transporte através de ciclovias. Prioriza-se o transporte motorizado e não o pedestre.

Ao contrário de Cuiabá, Várzea Grande possui a Superintendência de Transporte e Trânsito do município completamente desestruturada, sem técnicos, sem condições de planejar e gerenciar o setor. Sem adequação não haverá condições realizar as ações necessárias para implementar o Plano Diretor. 


\section{CAPÍTULO 08- SANEAMENTO AMBIENTAL E MEIO AMBIENTE}

O saneamento e o meio ambiente são pontos fracos tanto de Cuiabá como de Várzea Grande, sendo que a situação em Várzea Grande tende a ser pior pela falta de esgoto e pelas condições naturais da cidade, que como o próprio nome sugere (Várzea), possui em várias localidades o lençol freático alto, de forma que as fossas sépticas abertas podem se tornar cheias de água com facilidade e o lençol freático contaminado.

\section{1- SANEAMENTO AMBIENTAL EM VÁRZEA GRANDE}

O responsável em Várzea Grande pelo abastecimento de água e a coleta e tratamento de esgoto é o DAE, Departamento de Água e Esgoto do município, e segundo ele, $96 \%$ da população é abastecida com água potável.

Várzea Grande capta água do Rio Cuiabá (80\%) e de mananciais subterrâneos (20\%). São três locais de captação no Rio Cuiabá e 73 poços profundos em diversas áreas da cidade, mas principalmente na região Sul. Segundo o diagnóstico da VERTRAG, muitos destes poços não possuem tratamento completo e a água é injetada direto no sistema de distribuição, alguns possuem reservação.

Conforme diagnóstico da VERTRAG, a adução mais antiga, data de 1975, com extensão de $1.900 \mathrm{~m}$ até a ETA 1 , na Av. Ulises Pompeo de Campos. Devido ao aumento da demanda, foram acrescidas vazões entre os anos de 1999 e 2006 totalizando $1.476 \mathrm{~m}^{2} / \mathrm{h}$, está no limite de sua capacidade. A água captada é de péssima qualidade por estar a jusante do efluente de tratamento de esgoto, os cinco módulos não dão conta da purificação da água. A ETA 2, localizada na Estrada da Guarita, com extensão de $5.500 \mathrm{~m}$ também sofreu acréscimo no mesmo período que a anterior e sua vazão é de $1008 \mathrm{~m}^{2} / \mathrm{h}$, tem capacidade para ampliação mas precisa sofrer adequação (adequada lavagem de filtros). A terceira adutora ETA 3, localiza-se na localidade de Passagem da Conceição, com extensão de $150 \mathrm{~m}$, agrupa a captação e a ETA no mesmo local, e só atende esta comunidade, não está integrado aos demais sistemas e possui uma vazão de $10 \mathrm{~m}^{3} / \mathrm{h}$. O quarto sistema, o de poços, é bem versátil, pois permite o acréscimo de vazão quando solicitado, porém o tratamento é exclusivamente a base de cloro, problemas como o alto teor de óxido de ferro na água não é corrigido a contento, os custos de manutenção são altos. O déficit do fornecimento segundo o DAE é de $27.000 \mathrm{~m}^{2}$ por dia, o que pode (e com certeza é) ser bem maior pelas dificuldades com o sistema de poços, 
que precisa de tempo para manutenção e recuperação do aqüífero. A conclusão do ponto de vista técnico, e também do ponto de vista da comunidade é que o sistema é muito ruim, com constantes períodos de falta d'água nos bairros, de forma a piorar na periferia. Dos problemas com o abastecimento não escapa nem o Distrito Industrial da cidade.

A rede de tratamento de esgoto de Várzea Grande atende apenas de 10 ou $12 \%$ dos domicílios da cidade, totalizando uma rede de coleta de $40 \mathrm{~km}$, é, portanto muito reduzida. A meta para o ano de 2005 era de atender a $70 \%$ do município com rede e tratamento de esgoto, mas mesmo com o aumento de estações, continua atendendo as mesmas porcentagens (10 a 12\%). Isto acontece devido a falta de manutenção das ETEs, paralisando sua operação; atrasos no recebimento das análises atrasando as correções devidas; falta de controle das medições na chegada e no despejo de efluentes; e falta de equipamentos (bombas e geradores) para que as ETAs não parem de funcionar.

Os sistemas foram geralmente implantados para solucionar o problema nos conjuntos habitacionais, e no programa PROSEGE, e, portanto são pequenos sistemas isolados, caros, de difícil manutenção e expansão. Esta situação leva à contaminação dos rios e córregos, e o problema é agravado pelas características locais, na época da seca (inverno) o volume dos rios diminui muito e isto aumenta a concentração de poluentes.

O esgoto industrial é tratado geralmente pelas próprias indústrias (geralmente os frigoríficos tratam através de lagoas de estabilização) e a zona rural, assim como a grande parte da população, se utiliza de fossas sépticas e sumidouros.

Quanto a coleta de resíduos sólidos, toda a cidade e os distritos de Passagem da Conceição, Capão Grande e Bom Sucesso são atendidas com a coleta. No centro da cidade a coleta é de segunda a sábado, e no restante da cidade, três vezes por dia. $\mathrm{O}$ despejo é feito numa área municipal na BR - 070, nas proximidades do limite com Nossa Senhora do Livramento (desconfiava-se que a área ficava no município vizinho, mas com ajuda de GPS, constatou-se que pertencia realmente em Várzea Grande). A forma de disposição do lixo não é adequada, segundo a VERTRAG;

"Apesar das condições geológicas/geotécnicas do local de depósito ser aparentemente compatíveis com a disposição de resíduos, a forma de disposição não é a adequada. Os caminhões descarregam o lixo diretamente sobre o cascalho (concreções detrito-lateríticas), sendo 
posteriormente feita a cobertura com material retirado dos arredores da área de despejo (leito alterado), sob a forma de pequenos morrotes. É comum a permanência de catadores na área de disposição, que separam parte dos materiais recicláveis coletados”. (Volume II, pág. 259)

A disposição dos resíduos hospitalares é semelhante a do doméstico, mas é feita separadamente, em outro local, prática recente, tendo em vista que anteriormente tudo era feito conjuntamente. As embalagens de agrotóxicos são recolhidas pela Empresa Matogrossense de Pesquisa, Assistência e Extensão Rural S/A (EMPAER), procedendo como manda a legislação.

Os restos da construção civil são depositados aleatoriamente pela cidade, geralmente em áreas vazias do município, formando bolsões de lixo. Os pneus são recolhidos e separados no depósito. Posteriormente, uma empresa os recolhe para utilizar em fornos de calcinação de cimento. Não existe coleta seletiva na cidade e estuda-se a possibilidade da construção de um aterro em comum com Cuiabá.

O lixão desativado do município, nas proximidades da localidade de Pai André (sul da cidade) não recebeu tratamento adequado conforme legislação, e tem sido um ponto de contaminação ainda ativo.

Partindo deste diagnóstico para o setor, o Plano Diretor de Várzea Grande instituiu, no art. 26, as seguintes diretrizes e ações:

- Qualificar o sistema para otimizá-lo através da integração regional tendo em vista a redução da poluição hídrica de seu entorno.

- Elaborar o Plano Municipal de Saneamento.

- Atender a demanda de abastecimento de água do município (utilizando o Rio Cuiabá).

- Aumentar a eficiência do sistema de coleta e tratamento de esgoto.

- Elaborar projeto de instalação de fossas sépticas e sumidouros nas residências.

- Incentivar que as indústrias sejam responsáveis pelo seu próprio abastecimento de água e tratamento de seu esgoto.

- Elaborar Plano Diretor Municipal de Resíduos Sólidos.

- Implantar sistema de macrodrenagem urbana levando em consideração sua infraestrutura.

- Converter o atual lixão em aterro sanitário para lixo domestico e hospitalar. 
Observa-se que os problemas principais estão espelhados, porém as soluções ainda são apenas diretrizes vagas. Muitas das questões que podem, e devem, ser resolvidas a nível de aglomerado urbano (como o aterro sanitário comum aos municípios e um destino (via reciclagem) para os restos da construção civil, não aparecem sequer como diretrizes.

\section{2- AÇÕES PARA O SANEAMENTO AMBIENTAL EM VÁRZEA}

\section{GRANDE}

Quanto ao setor de saneamento ambiental, as ações tem por base o Plano Multisetorial Integrado - PMI - financiado pelo BNDES, que em Várzea Grande é chamado Bairro cidadão. Este programa iniciado por volta de 2002 possui foco voltado para os bairros mais carentes e subnormais, com ações de pavimentação, drenagem, rede de água e esgoto, além de regularização fundiária e de trabalho social nas comunidades. Este programa contempla com saneamento ambiental (rede de esgoto em especial) localidades carentes como o parque do lago, princesa do Sol, Boa Vista e Maringá I, II e III.. Também está em construção dois reservatórios na Av. 31 de Março, que contribuirá para melhorar o abastecimento de forma significativa da cidade. As linhas de crédito são o FINASA, o BNDES e OGU.

Quadro 14 - Localidades Projeto Bairro Cidadão

Cálculo da Área de Atuação PMI (Área de Atuação 4)

\begin{tabular}{|r|l|c|c|c|}
\hline Área & Local / Descrição & Atuação & Valor em m2 & $\begin{array}{c}\text { Valor } \\
\text { Cálculado } \\
\text { em (ha) }\end{array}$ \\
\hline & $\begin{array}{l}\text { Novo Horizonte - } \\
\text { Icaraí }\end{array}$ & Pavimentação e Drenagem & 1217439,5765 & 121,74 \\
\hline 2 & São Mateus & $"$ & 1963193,1751 & 196,32 \\
\hline 3 & Cidade de Deus & $n$ & 1256125,3781 & 125,61 \\
\hline 4 & São Simão & $n$ & 609084,5002 & 60,91 \\
\hline 5 & Lagoa do Jacaré & $n$ & 184982,0082 & 18,50 \\
\hline 6 & Jardim Vila Vitória & $n$ & 328581,9385 & 32,86 \\
\hline 7 & Maringá III & " & 297607,5628 & 29,76 \\
\hline
\end{tabular}




\begin{tabular}{|r|l|c|r|l|}
8 & Maringá II & $n$ & 272405,2834 & 27,24 \\
\hline 9 & Maringá I & $"$ & 477580,2245 & 47,76 \\
\hline 10 & Princesa do Sol & $"$ & 344582,3209 & 34,46 \\
\hline 11 & Parque do Lago & $n$ & 402878,9962 & 40,29 \\
\hline 12 & Boa Vista & $"$ & 95817,6646 & 9,58 \\
\hline
\end{tabular}

Fonte: Secretaria de Obras de Várzea Grande 2009

Total Parcial 745,03

\section{3- SANEAMENTO AMBIENTAL EM CUIABÁ}

Cuiabá possui um quadro um pouco melhor, embora a falta d'água seja reclamação constante. Em 1996 a responsabilidade pelo saneamento da cidade passou das mãos do Estado para a administração municipal, ficando a cargo da Secretaria Especial de Saneamento. No ano seguinte, foi criada a Agencia Municipal dos Serviços de Saneamento (AMSS), com o objetivo de regular e controlar a prestação dos serviços públicos de saneamento, sendo eles: o abastecimento d'água, esgotamento sanitário e coleta e disposição de resíduos sólidos de Cuiabá. Em 2001, a AMSS foi extinta e suas atribuições foram repassadas para a Secretaria Municipal de Meio Ambiente, no que tange a regulação e a normatização e a operação do sistema de informação, e os bens, direitos e obrigações para a Companhia de Saneamento da Capital - SANECAP (sociedade anônima de economia mista) que assumiu a parte referente ao abastecimento de água e esgotamento sanitário.

A SANECAP, segundo PERFIL SOCIOECONÔMICO DE CUIABÁ, VOL III, abastece $98 \%$ da população com água das ETAs São Sebastião I e II, Tijucal I e II, Parque Cuiabá, Ribeirão do Lipa, Coophema, e Porto. As ETAs produzem 2.472 1/s, somados aos 419 1/s dos 83 poços profundos que operam permanentemente ou em regime intermitente, totalizando 2.891 1/s. Em 2005, o número de ligações de água do município era de 130.335 .

Os distritos de Cuiabá, Nossa Senhora da Guia, Coxipó do Ouro e Coxipó da Ponte, são abastecidos com poços tubulares ou com poços da propriedade. A Zona Rural se abastece através de poços nas propriedades. 


\section{Segundo PERFIL SOCIOECONÔMICO DE CUIABÁ, VOL III:}

"O sistema de esgotamento sanitário existente em Cuiabá foi construído tendo por base projeto elaborado em 1952 pelo escritório Saturnino de Brito. Consistia em redes coletoras distribuídas por doze sub-bacias ou distritos, coletores -troncos ao longo do Córrego da Prainha, quatro estações elevatórias com seus respectivos emissários e uma estação de lodo ativado com aeração prolongada.

A capacidade prevista no projeto era da ordem de1601/s e a estação depuradora seria constituída de oito módulos de 201/s, dotado cada um de gradeamento, desarenador, tanque Imhoff e leitos de secagem. A descarga do efluente final da estação depuradora seria feita no Rio Cuiabá a aproximadamente $30 \mathrm{~m}$ da margem, por tubulação submersa". (pág. 402)

Deste projeto, que abrangia a construção de $18 \mathrm{~km}$ de rede coletora, só o primeiro módulo foi construído e, o pior, as ligações domiciliares não foram feitas, conseqüentemente, a estação não funcionou e acabou sucateada.

O sistema de esgotamento sanitário de Cuiabá funciona com três sistemas distintos:

- Sistema misto, que recolhe as águas pluviais e o esgoto em um único sistema;

- Sistema separador, com um sistema para as águas pluviais e outro para o esgoto sanitário;

- Sistema condominial, que cada um recolhe seu esgoto dentro de seu lote.

A principal estação de Tratamento é a ETE Don Aquino, do tipo lodo ativado com aeração prolongada e capacidade para tratar em torno de 600 1/s. Existem mais 13 ETEs de médio e grande porte, 20 de pequeno porte e 25 estações elevatórias. Segundo PERFIL SOCIOECONÔMICO DE CUIABÁ, VOL III, o tratamento processa-se em cinco lagoas de estabilização, duas estações de lodo ativado com aeração prolongada, três reatores anaeróbicos de fluxo ascendente (Rafas), dois decanto digestores Imhoff e vinte e um sistemas de fossas sépticas e filtros anaeróbicos.

A cidade conta com 47.699 ligações de esgoto, representando 38\% das ligações de água, mas apenas $29 \%$ do esgoto coletado são tratados, o que é muito crítico para meio ambiente e para a saúde da população.

Quanto a limpeza urbana, são coletados em Cuiabá, segundo a Prefeitura, 374 toneladas de resíduos sólidos domiciliares e comerciais, representando uma cobertura de $84 \%$ da cidade. A coleta é intermitente na maioria dos bairros. 
Seguindo as normas, os resíduos produzidos por estabelecimentos de saúde são recolhidos separadamente e depositados em valas sépticas. Estes resíduos representam $170 t$ por mês.

Desde 1996, Cuiabá opera uma usina de reciclagem, operada por cooperativa de catadores e 25\% dos resíduos que chegam à Central de Distribuição são destinados à reciclagem, que aproveitam cerca de 4 a 5\%. Infelizmente, a cidade não possui coleta seletiva.

A cidade conta com serviço de varrição de ruas (no centro, com maior periodicidade e principais bairros com freqüência menor), capinação nos terrenos da prefeitura, e manutenção de praças e canteiros.

Frente ao cenário apresentado, o Plano Diretor de Desenvolvimento Estratégico tem como principais metas (art. 14):

- Elaborar plano diretor para garantir o abastecimento de água e plano diretor para a coleta e tratamento de esgoto do município.

- Adensar as localidades já servidas com sistema de saneamento básico.

- Atender $100 \%$ da população com tratamento das águas residuais, em curto, médio e longo prazo, e atender $100 \%$ da população dos assentamentos regulares com água potável, priorizando as localidades mais adensadas.

- Realizar e concluir obras como a da Estação de Tratamento de Esgoto Dom Aquino; A implantação do coletor tronco e o tratamento de esgoto da região dos Bairros Jardim Florianópolis e Jardim Vitória, até o Ribeirão do Lipa (Parque das Águas) e a complementação do coletor tronco do Barbado desde o shopping Pantanal até a UFMT, em médio prazo;

- Revitalizar antigas estações de tratamento de esgoto.

- Estudar a viabilidade de abastecer Cuiabá com as águas da represa do Rio Manso.

- Disciplinar a perfuração de poços profundos.

- Garantir o abastecimento de água ininterruptamente na cidade.

- Implementar o plano de drenagem urbana.

- Disciplinar os prestadores de serviço de limpa-fossa e o lançamento em local apropriado, sem causar danos às estações de tratamento Enem ao corpo receptor. (obs: qual seria o local apropriado se as estações de tratamento não tratam nem o que o município recolhe?) 
- Articular com os diversos níveis de governo a elaboração de cadastro de galerias de água, esgoto e águas pluviais.

- Desvincular as redes de água e de esgoto.

- Elaborar projeto de recuperação do rio Cuiabá e afluentes.

- Implementar medidas de proteção nos mananciais do rio Cuiabá, Coxipó e Aguaçu, no sentido de assegurar a qualidade dos recursos hídricos destinados ao abastecimento de água no município.

- Condicionar a pavimentação de vias à execução de obras de drenagem.

O saneamento básico é um setor que necessitará de muita atenção, pois embora a prefeitura apresente $98 \%$ de domicílios atendidos por água potável, o serviço tem sido uma das principais reclamações da população, pois é intermitente o volume produzido para atender a todos, frequentemente a água é liberada sem pressão para alcançar os reservatórios das residências, a qualidade sofre oscilações e o abastecimento, intermitente, sendo comuns as localidades que na época da seca (inverno) ficam dias sem abastecimento. Quanto ao esgotamento sanitário, conclui-se que o quadro é bastante crítico e a cidade tem muito que investir em saneamento básico para a população, até mesmo quanto a limpeza urbana, vê-se que a periodicidade em certas localidades é insuficiente para manter a higiene, sem mencionar que em algumas ruas, no período das águas (verão), o caminhão de limpeza não consegue entrar. $\mathrm{O}$ saneamento ambiental necessitará de muito investimento e trabalho.

\section{4- AÇÕES PARA O SANEAMENTO AMBIENTAL EM CUIABÁ}

Quanto às ações que vem sendo desenvolvidas referentes ao saneamento ambiental, se destaca o projeto das centrais de depósito dos resíduos sólidos urbanos, especialmente tendo em vista a reciclagem. A prefeitura construiria em diversos lugares da cidade estrategicamente localizados, "ecopontos", que receberiam resíduos da construção civil e outros, como podas de árvores, eletrodomésticos e móveis que são descartados e o caminhão de lixo não recolhe. Até um metro cúbico de lixo, não se precisaria pagar, mais que isto, seria cobrado uma taxa. $\mathrm{O}$ lixo seria separado conforme sua natureza e os entulhos da construção civil, como restos de concreto, britas, pedras e tijolos seriam separados e encaminhados para uma usina de reciclagem onde seriam triturados e reutilizados na confecção de lastros de piso, calçadas, e outros 
concretos não estruturais. Para que o projeto funcione, seria necessário que Várzea Grande também fizesse parte, e instalasse os pontos para receber o entulho, procedendo da mesma forma que Cuiabá, inclusive fazendo a fiscalização para que os caçambeiros não atravessassem o Rio Cuiabá e depositassem os entulhos em qualquer lugar de Várzea Grande, mas isto ainda não aconteceu. A usina de reciclagem seria única para as duas cidades e seria operada por concessão. Porém até agora, apenas alguns pontos foram instalados em Cuiabá, enquanto Várzea Grande ainda está em conversação com a cidade vizinha. Cuiabá conta com uma usina de compostágem para o lixo urbano, e há uma preocupação com lixos hospitalares que possam conter peças radioativas, porém ainda sem solução declarada.

Quanto ao problema da falta de água, Cuiabá está tentando terminar a construção de ETA Tijucal, que vai melhorar o abastecimento da região do Coxipó. O PAC (Programa de Aceleração do Crescimento) tem financiado a implantação de redes de esgoto, e água, em inúmeras localidades (principalmente bairros periféricos e carentes como o Jardim Vitória, Florianópolis, União, entre outros).

\section{5- MEIO AMBIENTEEM VÁRZEA GRANDE}

Segundo o diagnóstico da VERTRAG, para Várzea Grande (e que pode ser verificado também para Cuiabá):

"As águas dos rios são degradadas também por conta do aumento da turbidez, proveniente de processos erosivos originados pelo manejo do solo inadequado e por processos de dragagem irregulares na planície e nos terraços aluvionares do Rio Cuiabá. Estas situações ocorrem em parte pela deficiência de fiscalização ambiental, porém são agravadas pela retirada das matas ciliares. Projetos de ampliação da rede de coleta e tratamento de esgoto doméstico, já previstos pela administração municipal, associados à distribuição de mudas de espécies nativas para recomposição da mata ciliar (por parte da Empresa Mato-grossense de Pesquisa, Assistência e Extensão rural S/A - EMPAER), são atitudes que tem como objetivo a minimização destes impactos". (VOL II, pág. 110 e 111).

O diagnóstico realizado para subsidiar o Plano Diretor várzea-grandense mostrou que as Áreas de Preservação Permanentes (APPs) junto aos rios estão sendo desrespeitadas tanto na Zona Urbana como na Rural. Isto acontece devido à falta de conhecimento sobre a importância das matas ciliares por parte da população e a 
deficiência da fiscalização por parte dos órgãos públicos. Projeto da EMPAER que objetiva a distribuição de mudas para o reflorestamento da mata ciliar, assim como o seu monitoramento, tem sido de grande importância para a recuperação destas áreas.

A ocupação de áreas sujeitas a alagamento e de áreas de preservação também é um problema a ser enfrentado pelo município. O desenvolvimento do distrito do Cristo Rei, que se situa entre o Rio Cuiabá e o Aeroporto Marechal Rondon, desperta o interesse pelas áreas junto ao Rio, que são desaconselhadas para ocupação tanto pela necessidade de se preservar a mata ciliar (e desta forma o próprio rio) e por serem suscetíveis às enchentes. Nas planícies aluvionáres mais próximas aos rios e córregos, há a elevação do nível do lençol freático, o que acaba inviabilizado a ocupação destas áreas. Mesmo sendo uma área sujeita a riscos ambientais (enchentes), o Distrito do Cristo Rei é a área mais adensada do município $\left(3.358 \mathrm{hab} / \mathrm{Km}^{2}\right)$. O problema se agrava com o aterramento e ocupação com resíduos de construção (entre outros) de lagoas que se formam naturalmente pela subida do lençol freático, e que ajudam a dar escoamento as águas. È o que ocorre com a Lagoa da FEB, e com a Lagoa do Jacaré, que além da precariedade das moradias sofrem com a falta de condições básica de infraestrutura. Bairros como o Planalto Beira Rio, Unipark, Santa Luzia, Vila Rica, Santa Clara, Maringá, Parque do Lago, Ipanema, Engordador, Parque São João, são vítimas constantes de enchentes, e que somadas a falta de esgotamento sanitário, drenagem, e pavimentação, causam constantes transtornos aos moradores na época das chuvas. Ainda assim, a região do Cristo Rei é alvo de grande interesse pela proximidade com Cuiabá. Após a construção da Usina do Rio Manso (importante afluente do Rio Cuiabá localizado a montante), as inundações provocadas pela subida do Rio estão sendo menores devido ao controle das águas liberadas pela barragem.

Cabe ainda mencionar as crateras abertas ao longo do Rio Cuiabá para exploração de argila que continuam sem recuperação, a dragagem do rio para obtenção de areia (e cascalho) para a construção civil que se não realizado conforme as leis ambientais podem causar prejuízo ao rio e à mata ciliar. No ano de 1997, 81 processos tramitavam junto ao Departamento Nacional de Produção Mineral (DNPM) para a extração mineral. A atividade mineral deve ser realizada perante a recuperação dos danos ambientais por elas causadas. Abaixo se apresenta quadro referente à atividade. Processos de atividade mineral em Várzea Grande. 
Quadro 15 - Extração Mineral em V. Grande

\begin{tabular}{|l|l|}
\hline Substância Mineral & Quantidade de Processo \\
\hline Areia & 40 \\
\hline Ouro (minério de ouro) & 22 \\
\hline Argila (argila refratária) & 12 \\
\hline Cascalho & 7 \\
\hline Total de processos & $\mathbf{8 1}$ \\
\hline
\end{tabular}

Fonte DNPM 2005

Apesar da Lei Orgânica do município autorizar em seu art. 204 a criação do Conselho Municipal de Defesa do Meio Ambiente, este não foi regulamentado, porém existe a necessidade de anuência prévia da Secretaria Municipal de Meio Ambiente para a implantação de certos empreendimentos que possam causar danos ambientais. Conforme a VERTRAG, pag. 110 da Síntese da Leitura Técnica e Comunitária.

"Existe a possibilidade de municipalização do licenciamento ambiental de empreendimentos de pequeno porte, na tentativa de diminuir o excesso de processos juntos ao órgão ambiental estadual. Trata-se de decisão muito importante, com expectativa de redução dos prazos de licenciamento ambiental e maior controle da secretaria municipal. Para efetiva execução da municipalização é fundamental a reestruturação da Secretaria Municipal de Meio Ambiente e Agricultura, tanto do ponto de vista de equipamentos quanto de corpo técnico, bem como a regulamentação e efetiva implantação do Conselho Municipal do Meio Ambiente, visando atender a nova demanda por serviços".

Existe ainda a questão da ocupação das APPs especialmente localizadas nas margens dos córregos, foi assim destacado pela Leitura Técnica - Volume II, elaborado pela VERTRAG.

"Durante as visitas técnicas em campo, observou-se que as APPs inseridas dentro do perímetro urbano, ou nas áreas urbanizadas localizadas em seu entorno, encontram-se em sua maioria, ocupadas de forma irregular por moradias, edificações de comércio, serviço e indústria e pelo próprio poder público.

As áreas onde se registra a ocupação mais intensa estão localizadas nas regiões centrais e mais adensadas do perímetro urbano, destacando-se: o Córrego General, Córrego Embaúval, Córrego Traíra e Córrego Água Limpa, Córrego do Aeroporto e Córrego Piçarrão.

O Córrego General e o Córrego Embaúval estão localizados na porção norte da área urbana, entre as avenidas Julio Campos e Mário Andreazza. Ao longo destes córregos localizam-se várias ocupações irregulares (ver subitem Áreas de ocupação irregular, ilegais e 
clandestinas), observando-se o total desrespeito à preservação das faixas de fundos de vale.

Em virtude da declividade acentuada, o Córrego Embaúval foi canalizado em alguns trechos para evitar alagamentos. O Córrego General, por outro lado, devido à pequena declividade de sua foz, espalha-se ao longo da margem oeste da Estrada da Guarita, provocando alagamentos freqüentes nas áreas ocupadas.

No Córrego da Água Limpa, que percorre os bairros de Engordador, Canto Verde, Ipase, Água Limpa e Centro, pode-se igualmente encontrar ocupações sobre APPs. De sua nascente na área central até a altura da Rua Nazareno no Bairro Ipase, o córrego foi retificado, observando-se poucas ocupações no fundo de vale. Desse ponto em diante, entre os bairros do Canto Verde e Engordador, densificam-se as ocupações. Outro trecho que se destaca é o Tanque do Fancho, localizado entre a sede da Prefeitura Municipal e o Loteamento Planalto Ipiranga, que abriga uma das nascentes do Córrego Água Limpa. Esta área de aproximadamente 1,5 ha vem perdendo espaço para as construções irregulares. Dentre estas ocupações destaca-se o estacionamento da Câmara Municipal, situado a menos de dez metros do leito do córrego, além de empreendimentos privados e moradias. Registram-se ainda as ocupações das áreas arrendadas na porção sul do terreno da Infraero, que segundo informações de técnicos municipais, cerca de $60 \%$ do córrego foi alterado.

Dois outros córregos que nascem no terreno do aeroporto apresentam situação irregular, um localizado próximo a Avenida da FEB, passando pelos loteamentos Santos Dumont e Manga, e outro que passa pela Lagoa do Jacaré, retornando ao aeroporto e desaguando no Rio Cuiabá entre os loteamentos Beira Rio e Jardim Ipanema. Estas áreas apresentam graves problemas de alagamento, freqüentes em épocas de chuva. Essa situação de risco agrava-se pela ausência de um sistema de drenagem urbana e pela falta de medidas de gestão pública frente às ocupações em áreas de preservação permanente". (pág. 187 a 189).

A partir destas constatações, alguns princípios e algumas diretrizes foram propostas e se transformaram em artigos do Plano Diretor Participativo de Várzea Grande.

Como princípio o município propõe a compatibilidade do uso do território com a garantia de qualidade de vida de seus cidadãos e a proteção do meio ambiente, sendo para tanto indispensável o fortalecimento da gestão municipal para a efetiva monitoração e o controle do meio ambiente (art. $7^{\circ}$, inc. IV e X). Cabe lembrar que o meio ambiente sustentável é considerado uma das funções sociais da cidade, e da propriedade (art. $9^{\circ}$ ) e que o art. 225 da Constituição Federal de 1988 estabelece como pressuposto para qualquer ação, a sustentabilidade ambiental. Desta forma, o art. 15 do PDP de Várzea Grande estabelece que: 
"É dever de todos zelar pela proteção ambiental em todo o território do Município, de acordo com as disposições da Legislação Municipal e com as normas adotadas pelo Estado e pela União”.

O Plano estabelece no art. 24 o difícil objetivo geral de realizar a conciliação das atividades com a ocupação ordenada e com a utilização dos recursos naturais, ficando estas, condicionadas à preservação da qualidade do ambiente, promovendo o desenvolvimento sustentável da região. Para tanto estabelece uma série de diretrizes no art. 25, sendo as mais significativas as seguintes:

- "impedir novas ocupações em áreas sujeitas a inundações, em especial nas planícies e baixos terraços aluvionares dos rios e nas lagoas do município" (inc. I);

- Identificar os limites das Áreas de Preservação Permanentes existentes e recuperar as matas ciliares (inc. II e III;

- Implantar ações para proteção das APPs (inc. IV);

- Elaborar mapa de aptidão dos solos do município, os pontos críticos sujeitos a inundações, e as APPs;

- Levantar as áreas degradadas, e promover ações para sua recuperação a partir da identificação das responsabilidades conforme a lei (inc.XV);

- Promover a cessação das atividades exploradoras de minérios das Zonas de Conservação e Proteção Ambiental e estabelecendo que recuperem a área degradada (inc. XIX);

- Fiscalização efetiva das dragas exploradoras de areia no Rio Cuiabá (inc. XVI);

- Incentivar a participação popular nas discussões que envolvam o ambiente (inc. XIV);

- Construção de parques municipais, da estrada parque ligando a ponte Sergio Mota até a localidade de Pai André, e a arborização da cidade.

Tendo em vista a situação crítica quanto ao meio ambiente, e a importância de se tratar o assunto de forma articulada com as demais cidades banhadas pelo Rio Cuiabá na região (Baixada Cuiabana), somada a falta de estrutura da prefeitura para lidar com a questão, pode-se concluir que não será fácil reverter os problemas ambientais no município. 
Não que faltem instrumentos urbanísticos para promover o controle ambiental no município, pois o Macrozoneamento já define as áreas de proteção tanto no meio rural como no urbano. Há também a previsão da geração de potencial construtivo da Área Urbana de Recuperação, Conservação e Preservação do Patrimônio Ambiental e Cultural (art. 67), para as áreas a serem adensadas, e o Zoneamento municipal estipulam índices menores para as áreas mais frágeis.

O Diagnóstico foi bastante preciso, e se apoiou em inúmeros mapas (Geológico e ocorrência de minerais; Geomorfologia; Potencialidades geoambientais; Ocupações irregulares; Coleta de lixo; Síntese ambiental (com diversas informações como localização de lixões, áreas contaminadas e áreas com contaminação do lençol freático e com cemitérios com problemas); Drenagem; Formação superficial; Hipsometria (altitudes); Limitações geoambientais; Zoneamento ecológico econômico e unidades de Conservação; Hidrogeologia; Recomendações geoambientais; Hidrografia; Síntese de infraestrutura e serviços; Solos; Plano da Zona da proteção do Aeródromo; Esgotamento sanitário e Síntese Ambiental Municipal). De forma geral, observa-se que o estabelecido para o planejamento territorial está de acordo com o diagnóstico, mas não existe a previsão de um plano municipal para o meio ambiente, nem de um conselho específico para tratar do assunto e nem de fundo municipal para o meio ambiente, o que torna ainda mais difícil a realização de ações voltadas para a solução dos problemas.

Cuiabá constatou os mesmos problemas verificados pela consultoria em Várzea Grande. Na leitura técnica e comunitária cuiabana, foram mencionados como problemas a serem enfrentados:

- A ocupação das áreas verdes e das beiras de rios e córregos do município por habitações.

- A degradação das Áreas de Proteção Ambiental, tanto na Zona Rural, quanto na Zona Urbana, referente à destruição de matas ciliares e, conseqüentemente, o assoreamento dos Rios e córregos da cidade.

- A poluição dos cursos d'água devido à falta de saneamento.

- Bairros situados em locais cuja cota está abaixo da cota de inundação do Rio Cuiabá (como o caso do Praieirinho).

- A degradação provocada pelas atividades econômicas, especialmente a mineradora (nos mesmos moldes do que ocorre em Várzea Grande);

- Falta de arborização nas ruas e praças de Cuiabá. 
- Grande número de terrenos mal conservados, e que recebem entulhos e lixos diversos oriundos da população mal servida de limpeza pública urbana.

- Falta de conhecimento ambiental por parte da população.

- Falta de estrutura da prefeitura para fazer o gerenciamento, a fiscalização e a monitoração do meio ambiente.

- A necessidade de se estabelecer o diálogo e parcerias com os demais municípios da Baixada Cuiabana, especialmente quanto aos assuntos relacionados ao Rio Cuiabá.

\section{6- AÇÕES PARA O MEIO AMBIENTE EM VÁRZEA GRANDE}

$\mathrm{Na}$ área ambiental, o subsecretário Celso de Souza Brandão diz que a Secretaria de Meio Ambiente vem se esforçando para cumprir o Plano Diretor, apesar da falta de estrutura do órgão. Segundo ele, faltam fiscais, sendo que contam com apenas dez para realizar toda a fiscalização do município, sem contar a falta de estrutura da Coordenadoria de Fiscalização. Portanto, existem dificuldades para coibir as ocupações das áreas sujeitas à inundações, das áreas de preservação e dos demais casos que exigem fiscais. A principal ação desenvolvida nesta área foi a desocupação de uma APP na Av. Júlio Campos, ação desenvolvida em parceria com o JUVAM (do Estado) e com os procuradores municipais.

Quanto à recuperação e ações para conservação das matas ciliares e áreas de preservação permanente, o subsecretário disse que estão em andamento, e que ainda não existe programa para arborização da cidade, mas que a cidade conta com um viveiro e que fornece as mudas de árvores para que as associações de bairro facão a recuperação de algumas áreas, como exemplo, está a arborização da Alameda Júlio Müller, e da localidade denominada de Carrapicho (região do São Gonçalo). São também arborizadas as áreas verdes (praças e equipamentos públicos em especial) que são objeto do programa chamado Várzea Grande Agora, que faz a arborização destes locais. A Agenda 21 de Várzea Grande tem como meta, além da fiscalização, a distribuição de mudas de árvores nativas da região para o reflorestamento das margens dos rios e córregos.

O mapeamento de aptidão do solo (art. 25, inc. IX do PDP), e outros mapeamentos tem apenas começado timidamente na Vila São João. Entre os anos de 
2005 e 2006 foi realizado em parceria com a Secretaria de Meio Ambiente de Cuiabá, um diagnóstico para detectar a situação das margens do rio Cuiabá, e resultou num termo de ajustamento de conduta para as dragas que retiram areia do leito do rio Cuiabá.

A EMPAER (Empresa Matogrossense de Pesquisa Agropecuária) tem oferecido assistência técnica para o manejo sustentável para as atividades agrícolas nas áreas rurais e realizado em conjunto com a Secretaria de Meio Ambiente o recadastramento das propriedades rurais (averiguação do tamanho, da produção entre outros itens) e o monitoramento dos assentamentos do município (Dorcelina Folador, Sadia I e III, Capão das Antas e Rio dos Peixes). Também o programa municipal denominado Agricultura Familiar, faz o preparo da terra por meios mecanizados (tratores) para que pequenos agricultores, em localidades mais carentes, possam plantar.

Em conjunto com o Corpo de Bombeiros, é realizado um trabalho de educação ambiental para prevenir queimadas. Este trabalho envolve ainda a Guarda Municipal e a Secretaria de Serviços Públicos. Existe também um trabalho nas escolas voltado para a reciclagem.

Outro trabalho desenvolvido visando a preservação ambiental do município foi o desenvolvido junto às cerâmicas. Cada cerâmica tinha uma área própria para a extração de argila, e as crateras abertas não eram recuperadas, nem utilizadas para nada. Criou-se então uma cooperativa para extração da argila de um local apenas e depois se realizar a recuperação da cratera, de maneira mais organizada e menos danosa para o meio ambiente.

Quanto às consultas prévias para os empreendimentos impactantes, a Secretaria de Meio Ambiente realiza uma parceria com a SEMA (Secretaria de Meio Ambiente do Estado de Mato Grosso) para a realização dos trabalhos.

Não se tem previsão de plano diretor setorial para o meio ambiente, sendo que os objetivos já estão contemplados na Agenda 21 e no Plano Diretor do município.

\section{7- MEIO AMBIENTE EM CUIABÁ}

Cuiabá estabeleceu como princípio a preservação e a recuperação do ambiente natural (art. $5^{\circ}$, inc. XI), como diretriz, no art. $9^{\circ}$, inc. XXIII, a promoção da proteção e recuperação do meio ambiente natural e construído.

As principais diretrizes instituídas, conforme o art. 12 do PDDE são: 
- A criação da Política Municipal de Meio Ambiente, e a integração entre as políticas ambientais do Município, Estado e da União (inc. I).

- Estimular a criação de comitês populares para divulgar e discutir as questões ambientais, e incentivar a participação da população na fiscalização (inc. IV e V).

- Proteger as áreas frágeis ambientalmente, impróprias para a ocupação e realizar a sua recuperação, (inc. VII, “a, b”).

- Elaborar programa de monitoramento das áreas verdes localizadas em condomínios e loteamentos (inc. VII, “e”).

- Estabelecer política de recuperação dos rios Cuiabá e Coxipó.

- Regulamentar o uso das águas superficiais e subterrâneas, assim como as atividades de lazer e turismo relacionadas a elas (inc.XIV e XV).

- Proibir os processos urbanísticos em áreas sujeitas a alagamento no município (XIX).

- Mapear e monitorar as áreas verdes municipais (inc. XX).

- Incentivar o plantio de arvores nos lotes através de redução do IPTU (inc. XXIV).

- Implementar a política de Educação Ambiental (art. XXXIV).

O diagnóstico referente ao ambiente tem sido realizado a partir das discussões nas conferências da cidade e da leitura técnica e comunitária, porém muitas das diretrizes (a maior parte) já eram conhecidas desde os estudos para a elaboração do Plano Diretor anterior, logo, pouca coisa pode ser feita nos últimos anos para realmente melhorar a situação, visto que as mesmas questões estão presentes, e até ampliadas, no atual Plano Diretor. As diretrizes e ações propostas, na maioria não apresentam datas para serem concretizadas, e até mesmo as que possuem tal previsão, como é o caso dos planos setoriais, que deveriam ser realizados em 360 dias a partir da promulgação do PDDE, e não tiveram seus prazos cumpridos, tendo em vista que ainda não foram realizados. Assim, os objetivos para o setor são de difícil concretização, tendo em vista a previsão do estabelecimento da política ambiental, e a falta de mapas precisos sobre as áreas críticas (e qual a problemática de cada uma), a necessidade de legislação mais adequada à realidade municipal, de estudos atualizados sobre a cidade e da dependência de reestruturação da Secretaria de Meio ambiente. Nem um cadastro atualizado e com bom grau de precisão sobre as áreas públicas a prefeitura possui, visto ser uma meta do 
PDDE, embora deva ser mencionado que já existam estudos em andamento, e que a organização e estruturação da Secretaria responsável pelo meio ambiente de Cuiabá encontra-se muito mais avançada em termos de estrutura administrativa que a de Várzea Grande.

\section{8- AÇÕES PARA O MEIO AMBIENTE EM CUIABÁ}

Apesar da existência de mapas referentes a Riscos de inundações, de Geomorfologia, de Declividade, de Expansão Urbana e de Restrição à Ocupação, de Localização preferencial do Comércio e da Indústria, e do zoneamento urbano estar de acordo com a infra-estrutura existente, existe a necessidade de estudos para maior precisão e atualização de muitos dados, pois devido à dinâmica urbana, e o fato dos mapas atuais terem como referência o diagnóstico realizado para o plano diretor anterior, não se conhece com segurança o que tem acontecido em todas as áreas a ser reestruturado, nas que deverão ser revitalizadas, nas que deverão ser preservadas (e qual o tamanho que estas deverão possuir), quais deverão ser objeto de recuperação.

O PDDE de Cuiabá possui a maioria das metas com baixo grau de autoaplicabilidade, e mesmo as que são auto-aplicáveis são de difícil execução tendo em vista que deveram ser transformados os hábitos da população, o que não acontece tão rapidamente, necessitando de bastante esforço, público e privado, para tanto.

O PDDE de Cuiabá estabelece a elaboração de um Plano Municipal para o Meio ambiente, no art. 12, inc. I, mas não prevê a instituição de um fundo para o setor, embora exista o COMDEMA - Conselho Municipal de Defesa do Meio Ambiente. O Plano tem como meta o incentivo da participação popular nas ações de fiscalização em outras discussões sobre o assunto, através de comitês populares.

A questão central referente ao meio ambiente é a ocupação das áreas impróprias para habitação seja elas regulares ou não, da mesma forma que se ocupam as áreas verdes e as áreas públicas, diminuindo os espaços para o lazer e para a construção de equipamentos públicos. O Plano Diretor estabelece no art. $9^{\circ}$, inc. XIX "a garantir a todos os habitantes do Município acesso a condições seguras de qualidade do ar, do solo, da água e de alimentos, de circulação e habitação em áreas livres de resíduos, de poluição visual e sonora, de uso dos espaços abertos e verdes". Sem uma política eficaz que permita aos mais necessitados terem acesso à terra urbanizada, e sem a devida fiscalização, é tarefa dificílima de ser cumprida. A favor do poder público, contudo, 
podemos citar a grande área demarcada como perímetro urbano com grandes porções vazias que possibilitam a realização de loteamentos para as classes menos favorecidas a preços razoáveis.

A preocupação com a qualidade das águas do Rio Cuiabá (que vem sofrendo com a degradação ambiental devido a falta de saneamento das cidades por onde passa, pela destruição das suas matas ciliares e pela ação direta da população, que atira lixo nas suas águas e margens), tem sido objeto de discussão entre as cidades do se vale, especialmente de Cuiabá e Várzea Grande, por serem responsáveis e representarem a área de maior impacto para o rio.

Quanto às ações desenvolvidas, a Secretaria de Meio Ambiente tem trabalhado em conjunto com o IPDU para estabelecer o Zoneamento Ambiental de Cuiabá, e apesar de existir o mapeamento das áreas verdes municipais, está sendo atualizada pela equipe da Secretaria, assim como existem estudos para identificar e criar as áreas de interesse de conservação e proteção ambiental, de forma especial, a APA da comunidade do Iguaçu, conforme estabelecido no Plano Diretor. Da mesma forma, se tem promovido o levantamento das áreas públicas degradadas e contaminadas, mas nenhuma foi ainda recuperada, embora o Plano Diretor estabeleça a recuperação de tais áreas deva se realizar em curto prazo.

O controle, monitoramento e fiscalização de cargas perigosas são realizados em conjunto com a SEMA (Secretaria Estadual de Meio Ambiente). Também o licenciamento ambiental tem sido realizado em conjunto com a SEMA. A cooperação com a UFMT (Universidade Federal de Mato Grosso) tem sido o caminho para a pesquisa para a substituição da frota de transporte coletivo por veículos que utilizem tecnologia menos poluente.

Quanto à educação ambiental, tem sido realizada através de parcerias com as escolas públicas e programas específicos.

Por fim percebe-se que a grave situação do saneamento ambiental tanto em Cuiabá como em Várzea Grande tem feito as prefeituras buscar metas consideradas ambiciosas e devido o sofrimento da população com a falta de água em cidades cujas temperaturas frequentemente beiram os $40^{\circ} \mathrm{C}$ faz com que estas ações sejam realmente cobradas. Ainda assim as obras do PAC que estão espalhadas principalmente pela periferia das cidades não desenvolvem a contento seguindo o cronograma e estão atrasadas por questões jurídicas e administrativas. Os planos diretores neste sentido elencam algumas metas, mas não citam as localidades mais necessitadas de saneamento 
como prioritárias. Algumas ações, neste setor, têm sido discutidas em conjunto, como uma solução para o aterro sanitário, os pontos de depósito de resíduos sólidos e principalmente a política para o Rio Cuiabá.

As ações voltadas para o meio ambiente existem nas duas cidades, mas não são muito ambiciosas e não se vê muitos resultados na cidade como, por exemplo, a arborização das calçadas e de praças, a coleta seletiva e a recuperação dos córregos das cidades. Se contrapondo a isso, o trabalho que se tem realizado para recuperar a mata ciliar nas margens dos Rios Cuiabá e Coxipó é visível e louvável, embora os Rios ainda sofram com a falta de tratamento do esgoto das cidades e com o lixo que neles é jogado.

Mais uma vez fica evidente que a estrutura municipal para gestão dos serviços públicos de saneamento ambiental e de meio ambiente é extremamente relevante para a melhoria da qualidade de vida e da saúde da população. 


\section{CAPÍTULO 09- ESTRUTURA ADMINISTRATIVA E CONTROLE SOCIAL}

Nenhum plano atinge seus objetivos se suas metas não se concretizarem. Para tanto, as prefeituras e a população deverão se mobilizar. A prefeitura, executando o controle urbanístico e as obras necessárias, gerenciando os recursos provenientes dos impostos. A população não pode ficar alheia ao processo e deverá se esforçar para estar buscando os canais de participação disponibilizados pelas prefeituras. Desta forma poderá haver o monitoramento da realização dos planos diretores. As prefeituras, como o canal mais próximo da população e linha de frente na efetivação das políticas públicas, deverá estar preparada para realizar um processo contínuo de planejamento, assim como estar proporcionando mecanismos para a população ter acesso e efetiva participação nos acontecimentos relativos à transformação da cidade. A estrutura administrativa será decisiva para que o sucesso dos planos.

O Estatuto das Cidades determinou que os municípios se preparassem para a abertura de canais para a participação da população. No art. 43 desta lei (lei federal 10.257 de 2001) está determinado que mesmo tendo caráter deliberativo, as audiências públicas implicarão na motivação do administrador público, que deverá ser norteado pelos debates e indagações que forem realizados.

Por outro lado, existe o problema das estruturas administrativas, que são arcaicas e pouco eficientes. Como já foi colocado, a prefeitura de Cuiabá está muito a frente da prefeitura de Várzea Grande em termos de organização administrativa e número de servidores, mesmo assim, muito se falou nos encontros para a leitura da cidade sobre a necessidade de ser aperfeiçoada a organização administrativa da capital, e principalmente tem se cobrado uma modernização da gestão urbana. Se em Cuiabá a questão é relevante, em Várzea Grande é decisiva para que a cidade possa ter a imagem de "cidade feia, sem atrativos, e sem identidade" revertida.

Nos dois planos diretores o problema se revela grave, tanto que a reestruturação dos órgãos é diretriz constante para vários setores, especialmente os que cuidam das questões físico-territoriais das cidades. Pede-se a reestruturação ou incrementação, e até criação, de órgãos que cuidam do transporte e trânsito, da habitação do meio ambiente, do saneamento, das obras, do planejamento e do desenvolvimento urbano. A questão da administração municipal, especialmente o planejamento urbano, foi tratada no plano diretor tanto de Cuiabá como de Várzea Grande. 


\section{1- ESTRUTURA ADMINISTRATIVA E CONTROLE SOCIAL EM VÁRZEA GRANDE}

A organização administrativa de Várzea Grande é instituída pela Lei 1602 de 1995, sendo apresentada a atribuição e os princípios de cada órgão.

A leitura técnica para a elaboração do atual Plano Diretor constatou algumas deficiências como a falta de esfera para discussão entre os secretários sobre o planejamento urbano, o que causa dificuldades na integração das ações e projetos, e a inexistência de esfera para a participação direta da população.

Quanto ao quadro de funcionários, foi apontado o excesso de cargos em comissão, a falta de plano de cargos e carreira para os efetivos, e a falta de capacitação técnica. Estes fatores travariam a modernização administrativa da prefeitura.

A Prefeitura Municipal de Várzea Grande possui a seguinte estrutura administrativa:

- DAE (Departamento de água e esgoto)

- FUSVAG (Fundação de Saúde de Várzea Grande)

- Guarda Municipal

- PREVIVAG (Previdência de Várzea grande)

- Secretaria de Administração

- Secretaria administrativa Regional do Cristo Rei

- Secretaria de Comunicação

- Secretaria de Administração e Cultura

- Secretaria de Fazenda

- Secretaria de Planejamento

- Procuradoria Geral

- Secretaria de Promoção Social

- Secretaria de desenvolvimento Econômico

- Secretaria de esportes e Lazer

- Secretaria de Governo

- Secretaria de Meio Ambiente e Agricultura

- Secretaria de Saúde

- Secretaria de Serviços Públicos

- Secretaria de Viação, Obras e Urbanismo

- Superintendência de Trânsito e Transportes Urbanos 
Organograma da Prefeitura de Várzea Grande (referente ao controle urbanístico)

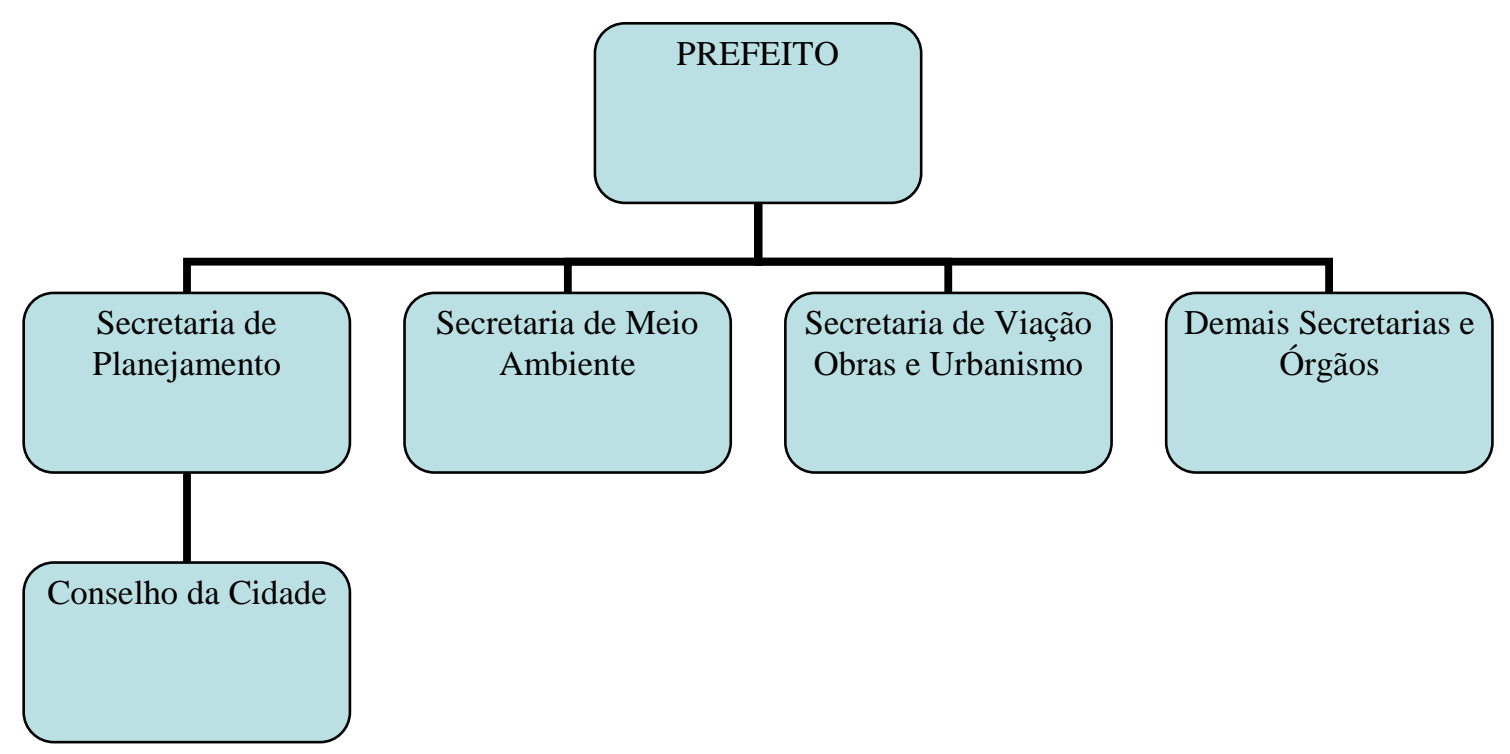

Figura 61 - Organograma da Prefeitura de Várzea Grande (2008)

Ao analisar as atribuições das Secretarias de Várzea Grande, observa-se que o controle urbanístico está atualmente dividido principalmente entre a Secretaria de Planejamento e a Secretaria de Viação Obras e Urbanismo. Em todas se desenvolve de forma secundária.

A Secretaria de Viação Obras e Urbanismo é responsável por fornecer os alvarás para construção, reforma e o Habite-se do imóvel, além de outras autorizações referentes às obras no município. Possui um corpo de fiscais para garantir que não seja construída nenhuma obra sem a devida permissão da Prefeitura e todo o setor de projetos urbanos e de edifícios públicos são realizados nesta secretaria, assim como as questões referentes à habitação.

A Secretaria de Obras (como é chamada) possui a seguinte estrutura:

- Coordenadoria de Obras

- Coordenadoria de Topografia

- Coordenadoria de Projetos (divisão de projetos, de aprovação de projetos e de fiscalização)

- Coordenadoria de Viação

- Dois assessores 
Apesar da estrutura, ela não é respeitada, principalmente na Coordenadoria de Projetos, pois o coordenador não possui autoridade junto à divisão de projetos, não sabe o que está se passando por lá, e até fisicamente o setor é separado, recebendo ordens diretamente do secretário. Há casos de desvio de função e muitas vezes não se conhece quem são os coordenadores e os chefes das divisões.

$\mathrm{Na}$ verdade, a secretaria de obras funciona como se fosse composta por diversas divisões ligadas diretamente ao Secretário, não obedecendo a uma rotina de procedimentos e nem a hierarquia funcional. Então temos a de Aprovação de Projetos, a de Fiscalização, a de Projetos, a de Orçamento de Obras, a de Viação (e de Terraplanagem), a de Topografia e alguns engenheiros que fiscalizam obras públicas que nem sabem a qual divisão pertencem. O cargo ocupado nem sempre corresponde à função real que a pessoa desempenha. Este modelo causa confusão e inúmeros problemas.

No site da prefeitura, a Secretaria apresenta como seus objetivos:

“(...) atender os anseios da comunidade, através da realização de obras públicas, tais como saneamento, urbanização, calçamento de ruas e estradas, proporcionando infra-estrutura adequada aos seus munícipes."

Desta forma, não há um setor específico para o planejamento da cidade, e muitas rotinas são inclusive realizadas várias vezes, e em várias Secretarias diferentes (como ocorreu com o mapa do perímetro urbano, elaborado na Secretaria de Meio Ambiente e na de Obras), e de projetos que são elaborados em um setor que ninguém sabia que existia na secretaria de saúde e ao mesmo tempo no Setor de Projetos, causando constrangimento aos técnicos.

A Secretaria de Meio Ambiente e Agricultura possui também um corpo de fiscais, que fiscalizam os problemas ambientais no município, e também aprovam projetos quando há a necessidade de estudo de impacto ambiental ou quando a natureza exige. Neste caso, a Secretaria de Obras envia o projeto a ser aprovado para a Secretaria de Meio Ambiente para sua análise e parecer.

A partir desta gestão, a Secretaria de Planejamento, que sempre fez o planejamento financeiro do município e mais recentemente, por força de Lei tem coordenado as reuniões do Orçamento Participativo, assumiu o encargo do Plano Diretor, ainda que sem nenhum conhecimento sobre o ambiente físico do município e sem a estrutura adequada. As atribuições da Secretaria, segundo site da prefeitura são: 
"Coordena a formulação, a execução e a avaliação das políticas públicas visando o desenvolvimento econômico, social e institucional do município, propõe e executa políticas relativas ao orçamento e à tecnologia da informação, bem como disponibiliza para a sociedade, informações sócio-econômicas e indicadores conjunturais da economia da cidade."

Atualmente, após aprovação do Plano Diretor, a secretaria conta com um técnico para tratar dos assuntos relativos ao planejamento urbano, e comandará as reuniões no recém criado Conselho da Cidade. Este conselho não terá poderes deliberativos, sendo somente um órgão consultivo, contará com técnicos das secretarias e com a participação da sociedade organizada.

A Lei vigente (Lei 1.602/95) segundo a leitura técnica realizada pela VERTRAG separou o planejamento urbano, responsável pela ordenação do uso e da ocupação do solo e do sistema viário e a gestão territorial, responsável pelo urbanismo, pela polícia administrativa e a fiscalização do uso do solo, em dois órgãos: a Secretaria de Planejamento e a Secretaria de Viação, Obras e Urbanismo. Todos os técnicos da Secretaria de Planejamento que cuidam dos aspectos urbanos não são funcionários efetivos, de forma que poderão deixar o quadro a qualquer momento. A Secretaria de Obras e a de Meio Ambiente contam com número muito reduzido de fiscais. Desta forma foi inclusive apontado pela população nas leituras comunitárias que as principais causas de desrespeito a legislação urbanística e a existência de ocupações irregulares está na ausência de planejamento urbano e de fiscalização do território.

Técnicos da prefeitura também apontam a dificuldade de se aplicar a legislação municipal por ser confusa e distante da realidade do município.

Assim o planejamento urbano tem sido deixado em segundo plano em Várzea Grande, mesmo com mais de um ano da aprovação do Plano Diretor, ainda não conta com uma estrutura adequada e nem com funcionários suficientes, representa uma atividade secundária nas secretarias, tratado como algo de menor importância frente aos gravíssimos problemas que a cidade apresenta no seu cotidiano. O fato de se planejar em uma secretaria e se executar o planejamento físico territorial em outra, no caso de Várzea Grande, é bastante problemático porque as ações entre as secretarias envolvidas no processo são desconectadas, ou executadas de maneira diversa do esperado. Veja que o planejamento físico territorial e o Plano Diretor, nem aparecem como objetivo ou missão da Secretaria de Planejamento. 
Várzea Grande coloca no art. 114 a definição de seu sistema de planejamento nos seguintes termos:

"Entende-se por Sistema Municipal de Planejamento e Gestão Socioespacial o conjunto de órgãos, normas, recursos humanos e técnicos que objetivam a coordenação articulada das ações dos setores público e privado e da sociedade em geral, bem como a integração entre os diversos programas setoriais e a dinamização e modernização da ação governamental".

"Parágrafo único. O Sistema Municipal de Planejamento e Gestão Socioespacial, conduzido pelo setor público, deverá garantir a necessária transparência e a participação dos cidadãos e de entidades representativas".

O sistema, conforme o art. 115 será composto pelo Órgão responsável pelo planejamento e pela gestão socioespacial do município, a ser criado, pelas Secretarias Municipais de Várzea Grande, sem definir quais, e pelo Sistema de Informações Municipais. O órgão responsável pela gestão socioespacial, que tanto foi solicitada a criação durante a leitura técnica, terá várias responsabilidades enumeradas nos incisos do art. 116:

I. "Comandar o processo de implantação, regulamentação e monitoramento e atualização permanente do Plano Diretor Municipal, detalhando planos, programas e projetos relacionados ao ordenamento e ocupação do solo;

II. Planejar e implementar a política municipal de promoção da habitação social e regularização fundiária e traçar as diretrizes para a execução de seus programas;

III. Implementar e atualizar o Sistema de Informações Municipais e outras informações necessárias à gestão e ao planejamento municipal;

IV. Promover o levantamento de dados estatísticos e a realização de estudos, pesquisas e diagnósticos de natureza territorial, necessários ao processo de planejamento;

V. Promover a articulação entre as Secretarias Municipais e o Conselho da Cidade de Várzea Grande;

VI. Discutir e concretizar, com órgãos federais, estaduais e municipais, parcerias, consórcios e/ou financiamentos para a implantação do Plano Diretor;

VII. Informar e orientar questões atinentes à legislação urbanística, rural e ambiental municipal;

VIII. Monitorar a implementação das políticas de desenvolvimento estabelecidas nesta Lei.

IX. Aprovação de projetos construtivos e de parcelamento do solo urbano;

X. Manter cadastro de informações e arquivo de plantas de edificações e parcelamentos do solo aprovados, alimentando e atualizando permanentemente o sistema de informações municipais;

XI. Expedir parecer em relação aos processos de licenciamento para localização e funcionamento de atividades econômicas no município; 
XII. Fiscalização do uso e da ocupação do solo no território municipal;

XIII. Fiscalização de Obras e Posturas Municipais;

XIV. Elaboração de projetos para execução de Obras pela Prefeitura;

XV. Coordenação da aplicação dos instrumentos da Outorga Onerosa do direito de construir e da transferência de potencial construtivo".

Desta forma nota-se que será um órgão fundamental que concentrará várias atividades referentes à porção física da cidade, devendo ser fundamental a sua estruturação para que a cidade se organize conforme o Plano, visto que caberá a ele a monitoração das políticas de desenvolvimento urbano contidas na Lei.

No Plano Diretor (art. $7^{\circ}$ ) foram previstos como princípios gerais a garantia da gestão democrática com a participação da população no processo de planejamento e desenvolvimento do Município. Em vários artigos isto fica expresso como se observa:

- Art. $7^{\circ}$, inc. II, contem a previsão da garantia da gestão democrática com a participação da população no processo de planejamento e desenvolvimento do Município;

- $\mathrm{O}$ art. 12 versa que as políticas públicas municipais se darão de forma democrática e participativa, com a participação direta dos cidadãos individualmente ou representados por organizações.

- Para as Operações Urbanas Consorciadas deve existir a participação dos proprietários, moradores e usuários permanentes e investidores para a autorização e implementação das intervenções (art. 72).

- Para a instituição de ZEIS, e instituição do conteúdo mínimo dos planos urbanísticos, deve contar com a participação da população (art. 92).

"O processo de elaboração do Plano Urbanístico deverá ser participativo, de acordo com o estabelecido no Título VI desta Lei." (art. $\left.92, \S 2^{\circ}\right)$.

- $\mathrm{O}$ art. 95 exemplifica as instâncias participativas para se promover a democratização e descentralização da gestão municipal, sendo eles:

I. Órgãos colegiados de política urbana;

II. Debates, audiências e consultas públicas;

III.Conferências;

IV. Conselhos;

V. Gestão orçamentária participativa; 
VI. Estudo de impacto de vizinhança;

VII. Projetos e programas específicos;

VIII. Iniciativa popular de projeto de lei.

- O art. 96 diz que "Além dos instrumentos previstos nesta lei, a Prefeitura Municipal de Várzea Grande poderá estimular a criação de outros espaços de participação popular".

- Consta no art.97 que a participação da população na gestão municipal será assegurada pelo poder público através da convocação obrigatória das entidades representativas e especialmente da população atingida pelos atos e decisões do poder público.

- No art. 101, o Plano estabelece que "O poder público promoverá a realização periódica de sessões públicas de debates sobre temas relevantes de interesse público" e o art. 102 versa que a "realização dos debates poderá ser solicitada à prefeitura pelos Conselhos Municipais e por outras instituições representativas de classe e demais entidades de representação da sociedade".

- A participação na gestão do município se dará também através dos conselhos municipais, que terão caráter consultivo, propositivo e fiscalizatório, dentro de suas atribuições, nos limites de sua competência, conforme estabelecido em lei (art. 108).

- $\mathrm{O}$ art. 110 institui o Conselho da Cidade com a função de realizar o controle das ações referentes ao desenvolvimento urbano.

O Conselho da cidade concede ao Conselho da Cidade a competência para acompanhar a implantação do Plano Diretor, analisando e opinando sobre questões relativas à sua aplicação, acompanhando o seu processo de atualização permanente, através da proposição de alterações podendo emitir parecer sobre propostas para sua alteração.

Neste sentido, um paço significativo para propiciar a participação popular, e democratizar o planejamento urbano foi, como manda o Plano Diretor, a criação do Conselho da Cidade de Várzea Grande, chamado Concidade - VG, instituído pela Lei $n^{\circ}$ 33211/2008. Seus participantes são paritários, vindos de órgãos da prefeitura (representantes da secretaria de obras, Planejamento, Meio Ambiente, Fazenda...) e de entidades organizadas do município. Seus mandatos são de dois anos, podendo ser renovado por mais um período de até dois anos. 
A finalidade do Concidade - VG é acompanhar a implementação do Plano Diretor, estudar, formular e fazer proposições para seus planos setoriais com participação social. Qualquer membro poderá apresentar assuntos para serem discutidos. Um dos primeiros trabalhos da Secretaria de Planejamento para nortear a gestão nos próximos quatro a nos foi elaborar um documento denominado "Plano Diretor em Ação”. Esse documento baseado nas sugestões das leituras técnica e comunitária (base do Plano Diretor) especifica como era (ou como é); como deverá ser; o artigo do Plano Diretor que subsidia a mudança, o que deve estar contido no PPA, na LDO e na LOA, e as fases de implantação (ou o que e quando fazer para a realização das ações). Segundo a secretária de Planejamento de Várzea Grande, Senhora Ester, saber dos demais secretários o que é prioridade na sua área, somada com as reuniões comunitárias para a elaboração do PPA - Plano Plurianual - participativo, tornou-se uma medida de suma importância para a realização do planejamento municipal. Desta forma se priorizou as ações mais imediatas para serem tendidas com o orçamento municipal nos quatro anos próximos estabelecendo o co-relacionamento entre o Plano Diretor municipal e o PPA, a LDO e LOA.

Como se pode notar, tanto Cuiabá como Várzea Grande estabeleceram, nos seus Planos Diretores inúmeras formas de participação popular, sendo que os conselhos foram objeto de especial cuidado.

\section{2- $\quad$ ESTRUTURA ADMINISTRATIVA E CONTROLE SOCIAL DE CUIABÁ}

As cidades pertencentes ao aglomerado Urbano Cuiabá - Várzea Grande possuem estruturas administrativas bastante diferentes para tratar a questão do planejamento urbano.

A Prefeitura de Cuiabá está administrativamente estruturada da seguinte forma:

- Secretaria de Finanças.

- Secretaria de Planejamento.

- Secretaria de Comunicação

- Secretaria de Cultura

- Secretaria de Saúde

- Secretaria de Esportes e Cidadania 
- Secretaria de Assistência Social

- Secretaria de Governo

- Secretaria de Infra-estrutura

- Secretaria de Educação

- Secretaria de Meio Ambiente

- Secretaria de Trabalho e Turismo

- Secretaria de Transito e Transporte

- Procuradoria Geral

- IPDU (Instituto de Pesquisa e Desenvolvimento Urbano)

- SANECAP (Companhia de Saneamento da Capital)

- Agencia Municipal de Habitação Popular

- Auditoria

- Cuiabá PREV

- Ouvidoria Geral

- Procon Municipal

- Conselhos Municipais (inclusive o da Cidade)

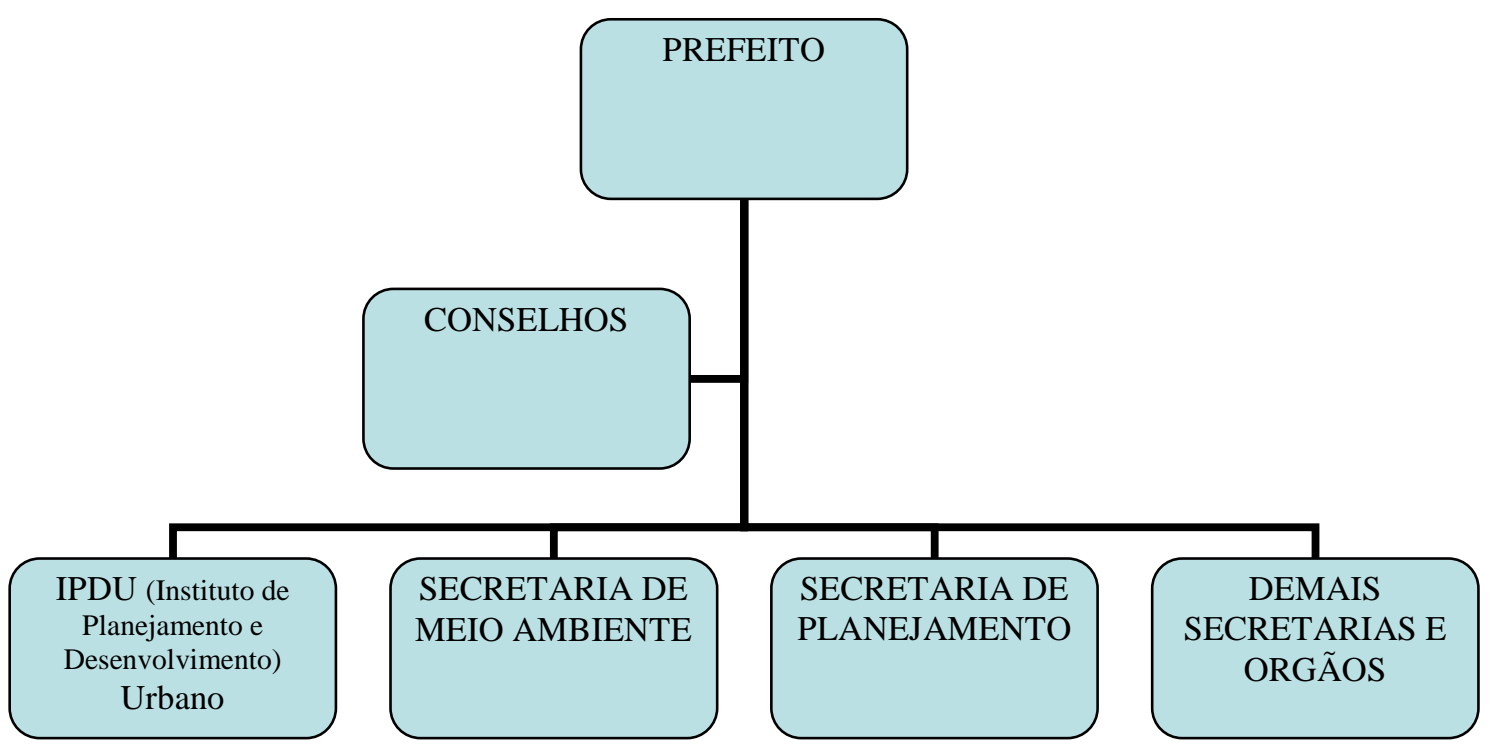

Figura 62- Organograma da prefeitura de Cuiabá (2008)

É sabido que o processo de planejamento urbano envolve todas as secretarias e órgãos da administração municipal, por se tratar de atividade multidisciplinar, onde diversos pontos de vistas se complementam para se formar um todo. Assim, nenhuma 
administração pública deve abrir mão de promover o diálogo entre os diversos organismos que a compõe, de maneira que todos colaboram para a formação da cidade e para o bem estar do cidadão. No entanto, alguns órgãos municipais se envolvem com maior intimidade com o processo de planejamento urbano (especialmente se tratando da questão física do município). Na prefeitura de Cuiabá, podemos citar como protagonista do processo de planejamento urbano o IPDU, embora outros órgãos também tenham um papel importante, como é o caso da Secretaria Municipal do Meio ambiente, da Secretaria de Planejamento, da Secretaria de Transporte e Trânsito, da Secretaria de Infra-estrutura, da Agencia Municipal de Habitação e em menor escala as Secretarias de Cultura, a de Turismo a de Assistência Social e os demais. Os conselhos, especialmente o da Cidade, também possuem um papel importantíssimo, pois representam a ponte entre a prefeitura e a população da cidade. Em Cuiabá, os conselhos não possuem poder deliberativo, apenas consultivo, mas todas as questões importantes relacionadas à cidade, são discutidas no Conselho da Cidade.

O IPDU (Instituto de Pesquisa e Desenvolvimento Urbano) é o órgão de planejamento do Sistema Municipal de Desenvolvimento Urbano de Cuiabá (SMDU) e é responsável, conforme seu site por:

"I - Coordenar o processo participativo de elaboração das propostas setoriais para a consolidação do Plano Diretor de Desenvolvimento Urbano - PDDU”;

II - Propor planos, programas, projetos e estudos vinculados aos objetivos estabelecidos no Plano Diretor;

III - Organizar e Gerenciar o Sistema de Informações para o Planejamento;

IV - Assessorar e prestar apoio técnico e administrativo ao Conselho Municipal de Desenvolvimento Urbano;

V - Elaborar o Relatório Anual de Atividades do Sistema;

VI - Realizar e promover pesquisas e estudos básicos necessários a fundamentação do Plano Diretor e seus desdobramentos;

VII - Gerenciar a execução de programas especiais;

VIII - Promover a capacitação de recursos humanos da rede sistêmica de planejamento;

IX - Prestar apoio técnico de planejamento aos órgãos executores do SMDU, visando nivelamento de conceitos e de linguagem metodológica tendo por fim o aperfeiçoamento de caráter integrado da ação de desenvolvimento; 
"XI - assegurar no Município o Planejamento como um processo contínuo e permanente."

O IPDU está organizado da seguinte maneira: Presidência, Diretoria Executiva, Assessoria Jurídica, Assessoria de Comunicação, Assessoria Especial, Diretoria de Pesquisa e Informação, Diretoria de Plano Diretor, Diretoria de Projetos Especiais, Gerências Técnicas e Administração sistêmica (Coordenadoria Administrativa e Financeira)

A criação do IPDU foi um paço importantíssimo para consolidar o planejamento urbano em Cuiabá, e a independência que possui em relação aos demais órgãos da prefeitura - já que não esta vinculado a nenhum - faz com que possa subsidiar a todos, especialmente com as informações (mapas, estatísticas, notícias etc.). No entanto, a grande quantidade de cargos de confiança, fragiliza a continuidade das ações e da capacitação, tendo em vista que core-se o risco de ver grande parte de seu pessoal deixando o órgão a cada quatro anos.

A Secretária Municipal de Meio Ambiente foi confiada toda a parte de aplicação das Leis urbanísticas e ambientais, podendo exercer o poder de polícia para seu efetivo cumprimento. É nesta secretaria que são feitas as aprovações de projetos de construções e ampliações, são analisados os EIVs - Estudo de Impacto Ambiental - e são concedidos os alvarás de funcionamento. Assim, é regulado e fiscalizado o uso e a ocupação do solo urbano. A sua missão, segundo site da prefeitura é:

"Promover o gerenciamento urbanístico e ambiental, mediante a construção de políticas públicas e da aplicação efetiva da legislação, visando a ocupação sustentável do solo urbano e rural para a melhoria de qualidade de vida dos munícipes."

Cabe a esta secretaria coibir a ocupação irregular das áreas de preservação ambiental, os usos inadequados, as construções em desacordo e outras irregularidades que possam vir a prejudicar o ambiente da cidade.

A Agencia Municipal de Habitação Popular cabe todos os assuntos relacionados à oferta de moradias para as classes mais carentes e o enfrentamento dos inúmeros problemas fundiários do município.

A Secretaria de Planejamento trata do orçamento municipal, se relacionando de forma igualitária com todas as demais secretarias e órgãos municipais. 
Observa-se que o orçamento municipal; as leis urbanísticas e os Projetos Urbanos; e a controle urbanístico, são feitos em secretarias diferentes, respectivamente a Secretaria de Planejamento, o IPDU, e a Secretaria de Meio Ambiente. O maior conflito ocorre na separação entre fazer a atualização da lei e cumpri-la, pois estando em secretarias diferentes, nem sempre isso acontece sem conflitos e divergências. Porém, nota-se que as secretarias e o IPDU possuem uma boa organização, contam com pessoal capacitado e, embora o número de servidores ainda não seja o ideal, conseguem desenvolver as atividades pertinentes a cada um com eficácia. Cabe ainda ressaltar que a Prefeitura de Cuiabá promoveu a revisão do Plano Diretor Municipal, conforme o Estatuto da Cidade e o Ministério da Cidade apregoam e no tempo estipulado ${ }^{8}$, sem a ajuda de consultoria, contando apenas com seus técnicos.

O Plano Diretor tratou da questão administrativa conforme exposto abaixo.

O PDDE de Cuiabá diz no art. 53 que:

"O Gerenciamento Municipal será operacionalizado através de definições estabelecidas pelo Sistema Municipal de Planejamento e Desenvolvimento Estratégico, reunindo preferencialmente as seguintes áreas de atribuição: controle do Patrimônio Imobiliário, Licenciamentos e Fiscalização Centralizada nas áreas de obras, edificações, meio ambiente, posturas municipais e situações correlatas".

Para o planejamento urbano, o art. $7^{\circ}$ diz o seguinte:

"O processo de planejamento municipal dar-se-á de forma integrada, contínua e permanente, em conformidade com as diretrizes estabelecidas nesta lei, sob coordenação, acompanhamento e avaliação da Fundação Instituto de Planejamento e Desenvolvimento Urbano de Cuiabá - IPDU”.

Para tanto deverá atualizar e disseminar as informações de interesse do Município; - orientar o Plano de Ação da Administração e das Leis do Plano Plurianual, de Diretrizes Orçamentárias e do Orçamento Anual, realizar o ordenamento em conformidade com a função social da cidade e promover a participação democrática da população na gestão pública municipal. A forma regionalizada foi assumida pelo PDDE para melhor organização da administração pública a fim de atingir seus objetivos.

\footnotetext{
${ }^{8}$ As prefeituras tinham até outubro de 2006 para revisarem seus planos diretores, muitas deixaram para a última hora e não conseguiram efetuar a revisão no prazo, como foi o caso de Várzea Grande, que embora com consultoria financiada por convênio com o Governo Federal, atrasou vários meses.
} 
O sistema de Planejamento Urbano está definido no art. 41 da seguinte forma:

"O Sistema Municipal de Planejamento e Desenvolvimento Estratégico - SMPDE é a concepção político-institucional nascida da sólida união de propósitos e esforços entre a comunidade organizada e o Governo, visando ao crescente aperfeiçoamento do processo de concepção e implantação da Política Municipal de Desenvolvimento Urbano e Rural. O SMPDE tem por finalidade articular, compatibilizar, integrar e promover a atuação harmônica dos órgãos e entidades, agentes diretos ou indiretos do Desenvolvimento Estratégico de Cuiabá".

Este sistema será composto por órgãos da prefeitura e pelo conselho municipal e pela sociedade organizada, especial - conforme o plano diretor, os seguintes:

- Conselho Municipal de Desenvolvimento Estratégico - CMDE

- Secretaria Municipal de Meio Ambiente e Desenvolvimento Urbano;

- Fundação Instituto de Planejamento e Desenvolvimento Urbano - IPDU;

- Órgãos das Administrações Públicas Federal, Estadual e Municipal, direta e indireta, responsáveis total ou parcialmente pela execução de Programas Setoriais de interesse direto dos Desenvolvimentos Urbano e Rural de Cuiabá;

- Entidades civis representativas de setores organizados da sociedade, relacionados aos objetivos do Sistema.

O sistema envolve uma série de atividades cíclicas além da produção dos seguintes instrumentos:

I-“" lei de Diretrizes Orçamentárias (LDO);

II- diretrizes Programáticas Setoriais;

III- propostas Setoriais;

IV- lei do Orçamento Anual (LOA);

V- plano Plurianual (PPA);

VI- projetos Executivos;

VII- convênios, Acordos e Contratos;

VIII- relatórios de Acompanhamentos e de Avaliação;

IX- relatório Anual de Atividades". (incisos do art. 43 do DDE)

Está previsto até a confecção de um Manual de Procedimentos visando a normatização e a padronização metodológica, além dos prazos e rotinas para a produção participativa dos instrumentos acima citados. (parágrafo único do art. 53).

O Plano de Cuiabá estabeleceu como princípios orientadores do Sistema Municipal de Planejamento a democracia do acesso à informação, a eficiência e eficácia na utilização dos recursos financeiros, técnicos e humanos, integração das políticas, 
planos e programas setoriais, a viabilidade técnica e econômica das proposições, avaliadas a partir do interesse social da solução e dos benefícios públicos, e o respeito e adequação às realidades local e regional conforme os planos e programas estaduais e federais existentes.

O sistema de planejamento deverá ser mantido atualizado e para isso contará com um sistema de informação. Conforme o art. 48 do PDDE, o sistema de informação deverá atender aos princípios da simplificação, moralidade, economicidade, eficácia, clareza, precisão e segurança. Deverá evitar o retrabalho e ter indicadores de qualidade para os serviços públicos. A ampla divulgação deverá ser garantida por meio de publicação anual disponibilizada na página eletrônica da Prefeitura para todos os munícipes, e por todos os meios possíveis e adequados. $\mathrm{O}$ art. 50 garante a todos o direito às informações relativas a elaboração, revisão e implementação do Plano Diretor, sendo requeridas por simples petição.

A população participa da gestão urbana através dos conselhos, das audiências e consultas públicas. O plano só estabelece a obrigatoriedade de conferências para ouvir a população afetada no caso de empreendimentos sujeitos a elaboração do Estudo de Impacto de Vizinhança - EIV que neste caso são obrigatórias para a aprovação destes. O Plano não estabelece, contudo, definição quanto à periodicidade destas consultas apenas diz que é um dos princípios do PDDE a participação popular nos processos de decisão, planejamento e gestão. (art. $5^{\circ}$, inc. XIV).

$\mathrm{O}$ art. 44 institui o Conselho Municipal de Desenvolvimento Estratégico de Cuiabá - CMDE é um órgão colegiado de natureza deliberativa, consultiva e recursal, tendo por finalidade, além de formular, acompanhar e avaliar a execução da Política Municipal de Desenvolvimento Estratégico:

"I- estabelecer os objetivos, as diretrizes, os instrumentos e as de Cuiabá;

Prioridades da política municipal de desenvolvimento estratégico

II- promover a integração das ações públicas e privadas e a harmonização de seus objetivos;

III- promover a articulação constante entre Município, Estado, União e a sociedade civil organizada visando a compatibilização das políticas e dos programas de apoio ao desenvolvimento urbano e rural;

IV- apreciar e encaminhar ao Chefe do Executivo Municipal o Plano Diretor de Desenvolvimento Estratégico, as Diretrizes Programáticas e Orçamentárias, o Orçamento Anual, o Plano Plurianual de Investimentos;

V- elaborar seu Regimento Interno; 
VI- emitir parecer, em última instância sobre Recursos interpostos em relação à aplicação da Legislação Urbanística Municipal”. (art. 44)

A composição do Conselho será a seguinte:

“a) 6 (seis) Conselheiros do Poder Executivo Municipal;

b) 6 (seis) Conselheiros de Entidades da Sociedade Civil Organizada;

c) 6 (seis) Conselheiros de Órgãos Federais e Estaduais;

d) 6 (seis) Conselheiros de Fiscalização Profissional;

e) 6 (seis) Conselheiros do Setor Empresarial;" (incisos do art. 45).

Seus conselheiros terão mandato de dois anos, podendo haver uma recondução, não terão remuneração, e devendo, as representações das entidades, serem renovadas $1 / 3$ a cada dois anos. (parágrafos do art. 44).

Conforme o art. $88, \S 2^{\circ}$ e $3^{\circ}$ :

$\S 2$ "O acompanhamento e controle social do Plano Diretor de Desenvolvimento Estratégico de Cuiabá será realizado por Conselhos Regionais e Distritais a serem criados por Lei Ordinária de iniciativa do Poder Executivo, dentro de 60 dias a contar da publicação desta Lei Complementar.

$\S 3^{\mathbf{0}}$ Em cada região administrativa e distrital haverá um Conselho de acompanhamento e controle, integrado por 9 (nove) conselheiros, representando as diversas entidades da sociedade civil organizada.

As questões urbanas e relativas aos aspectos físicos da cidade serão discutidas e acompanhadas pelo CMDE (Conselho Municipal de Desenvolvimento Estratégico).

Quanto aos conselhos, deverão ser reestruturados, redimensionados quanto à atuação, e serem fortalecidos conforme o art. 30, inc. XI, de forma a incrementar a participação destes nas políticas públicas. O Plano prevê a realização da integração entre os órgãos, entidades e conselhos, visando à atuação coordenada no cumprimento das estratégicas fixadas este Plano e na execução de programas e projetos suplementados. (art. $5^{\circ}$, inc. XVI).

Para os diversos conselhos, o Plano cita diversas metas para os conselhos municipais, como as seguintes:

- O fortalecimento do controle, da área da saúde municipal através do Conselho Municipal de Saúde, Conselhos Gestores e demais formas de organização social; (art. 20, inc. V) 
- A promoção do Conselho Municipal de Educação proporcionando condições para a manutenção e seu funcionamento "(art. 22, inc.XIV);

- Proporcionar o fortalecimento, a implementação, e a estruturação tendo em vista o bom funcionamento dos Conselhos de Direitos e dos Conselhos Tutelares. (art. 25, inc. IV);

- Fortalecer o Conselho Municipal dos Direitos da Mulher. (art. 28, inc. IV);

- Garantir a criação e funcionamento dos Conselhos Municipais Regionais de Defesa e Cidadania assim como da Guarda Municipal (art. 29, inc. II);

- Implantar o Fundo Municipal de Defesa e Cidadania, com vistas a captação de recursos destinados ao financiamento das Políticas de Defesa e Cidadania (art. 29, inc. III).

Finalizando, percebe-se que a prefeitura de Várzea Grande esta instituindo um órgão para tratar de habitação e de questões urbanas, mas não se obteve informações sobre sua estrutura, e nem atribuições. De qualquer forma, será um grande avanço se reunir as atribuições voltadas ao planejamento físico territorial da cidade e da habitação.

Cuiabá, que já possui uma estrutura consistente e bem estruturada não propões mudanças administrativas, apenas a estruturação e reestruturação dos seus órgãos.

Os conselhos ganharam força com os Planos Diretores atuais, sendo que em Cuiabá já era comum a apreciação de diversos temas, questões e projetos pelos conselhos. Em Várzea Grande as reuniões (semanais) do Concidade tem sido bastante prestigiadas e até polêmicas, devido aos diversos interesses antagônicos que começam a despertar dependendo do assunto tratado. A cidade ganha em democracia, apesar de que as atas das reuniões dos conselhos deveriam ser veiculadas pela internet, possibilitando a qualquer munícipe acompanhar o que acontece nas reuniões.

Verificou-se que a administração municipal faz toda a diferença na prestação dos serviços e no desenvolvimento urbano. Cuiabá que possui uma estrutura administrativa moderna consegue gerenciar melhor a cidade, controlar o uso e ocupação do solo, formular planos, projetos e proporcionar melhorias para a população, em nível mais elevado que Várzea Grande, que possui dificuldades na organização institucional da prefeitura.

As questões referentes à administração pública se revelam decisivas para a implementação do Plano Diretor, sem técnicos capacitados, motivados e com condições de trabalho não será possível a transformação urbana esperada pela população. 


\section{3- DIRETRIZES PARA O AGLOMERADO URBANO E REGIÃO}

Com a finalidade de promover o desenvolvimento integrado dos municípios de Cuiabá e Várzea Grande, além de formular planos, programas e projetos de interesse comum, de aprovar, e emitir pareceres e ainda propor metas e prioridades, a concretização das propostas acabam por se deparar com a limitação imposta pela ausência de competência legal para a contratação de obras, o que acaba inviabilizando vários projetos.

Tanto Cuiabá como Várzea Grande reconhecem a necessidade de planejarem e de executarem algumas ações em conjunto, em áreas cuja integração é fundamental. Assim, a questão do aglomerado urbano se fez presente nos planos diretores das duas cidades.

Como princípio geral do Plano Diretor Participativo de Várzea Grande, no art. $8^{\circ}$, inc. I, consta a intenção de estar participando de uma gestão comum, visando:

\footnotetext{
"aumentar a eficácia da ação governamental, promovendo a integração e cooperação com outros municípios, com os governos Estadual e Federal e com a iniciativa privada no processo de planejamento e gestão das questões de interesse comum".
}

Cuiabá também expressa no art. $3^{\circ}$ de seu Plano que esta lei visa também “(...) proporcionar o desenvolvimento integrado, harmonioso, o bem-estar social e a sustentabilidade de Cuiabá e da Região do seu entorno, (...)" e ainda, que o seu Plano deverá ser compatível com o planejamento da Região Polarizada de Cuiabá, e que se integre no contexto regional, estadual e nacional (art. $6^{\circ}$, inc. I).

Várzea Grande coloca no art. 18, inc. V, como diretriz para o desenvolvimento institucional do município, a necessidade de mover esforços para dotar o Aglomerado Urbano de competência para a execução de ações e projetos de interesse intermunicipal.

O sistema viário e o transporte são pontos cruciais para o desenvolvimento da região e para a qualidade de vida de seus habitantes. Várzea Grande coloca no seu Plano, a preocupação com o incremento da malha de forma articulada para proporcionar fluidez ao transito local e orientar a circulação dos diferentes tipos de tráfego de veículos entre as cidades do Aglomerado Urbano, articulando-os às pontes que cruzam o rio Cuiabá, propiciando a construção de anéis viários, a continuidade do sistema viário entre as duas cidades e (art. $7^{\circ}$, inc. III; art. 27, inc. III de VG). Cuiabá deseja, conforme 
art. 10. inc. XIV de seu PDDE, "promover estudos técnicos de ligação viária estratégica entre Cuiabá e Várzea Grande”.

Cuiabá também coloca a intenção de "melhorar e ampliar a integração do transporte público coletivo em Cuiabá e buscar a consolidação da integração do transporte público coletivo em Cuiabá e buscar a consolidação da integração do aglomerado urbano. (art. 11, inc.XV do PDDE de Cuiabá).

A questão do Rio Cuiabá, como elemento de grande potencial e de integração entre os municípios faz com que o planejamento e gestão integrada, via Aglomerado Urbano seja desejada, de forma que Várzea Grande colocou no art. 28, inc. I, a necessidade de se propor um desenho territorial que considere a Capital, e Cuiabá quer a integração na questão do gerenciamento dos resíduos sólidos do Aglomerado (art. 13, inc. V do PDDE de Cuiabá).

A dimensão que as questões comuns têm alcançado, e a urgência das providências fizeram com que o Estado de Mato Grosso criasse recentemente a Região Metropolitana do Vale do Rio Cuiabá, com quatro cidades integrantes: Cuiabá, Várzea Grande, Santo Antônio de Leverger e Nossa Senhora do Livramento. Também foi criada uma área de entorno que, apesar de não ter a intensa interação com a Região Metropolitana, também sofre forte influencia comercial, cultural e social. Compõe a área de entorno os municípios de Chapada dos Guimarães, Nova Brasilândia, Planalto da Serra, Acorizal, Jangada, Nobres, Rosário Oeste, Barão de Melgaço e Poconé. A estrutura de gestão da Região Metropolitana (agência metropolitana, conselho de desenvolvimento e fundo metropolitano agência metropolitana, conselho de desenvolvimento e fundo metropolitano) ainda está sendo desenvolvida. Desta forma, o Aglomerado Urbano (com sua estrutura) continua em funcionamento, inclusive encontra-se aprovado um convênio com o Ministério das Cidades para a elaboração do Plano Diretor Integrado do Aglomerado Urbano Cuiabá - Várzea Grande, e também há o consórcio visando o fortalecimento das cadeias produtivas locais, abrangendo os municípios da Região Metropolitana do Vale do Rio Cuiabá e os demais integrantes da região de entorno. Estas ações melhorarão as condições econômicas, ambientais, urbanísticas e sociais da região de entorno do Vale do Rio Cuiabá.

As cidades de Cuiabá e Várzea Grande citam a busca pelo planejamento urbano de forma integrada, mas não é isso que se tem verificado na prática, tendo em vista que nenhum projeto saiu do papel ou do campo das discussões. 


\section{CAPÍTULO 10 - CONCLUSÃO DO TRABALHO}

\section{1- CONCLUSÃO}

Os inúmeros problemas urbanos, não foram causados pela falta de planos, mas pela falta de planejamento, porque planos sempre existiram, porém a realidade política e social as quais as cidades brasileiras se inserem exigem mais que planos e projetos, exigem ações concretas, assim as formas de conduzir as cidades não se mostraram eficazes, mas sim deslocadas da realidade vivida no país. Planejamento é mais que planos, é formado por diagnóstico, planos, projetos, políticas, ações, avaliações e revisões num ciclo contínuo que deve fechar.

O Estado, utilizado pelas elites capitalistas, historicamente utilizou o dinheiro público, para proporcionar a estrutura adequada para que uma parcela da população tivesse acesso a uma cidade bonita, bem cuidada e equipada com tudo o que se precisa para viver bem. Através das obras realizadas pelo poder público (seja local, regional ou nacional), muitos empresários lucraram com a valorização do solo e com a infraestrutura que os beneficiavam gratuitamente. Contudo, a situação tornou-se insustentável e a parcela excluída da população passou a cobrar a parte dos benefícios que lhes cabe. A luta pela reforma urbana teve como fruto o Estatuto da Cidade, lei que tem sido a esperança de mudanças concretas nos rumos que as cidades brasileiras tomaram. Não é, contudo, tarefa fácil.

O planejamento urbano no Brasil foi tratado então de forma secundária pelos gestores governamentais que sempre, ao longo da história, preferiram executar projetos e planos numa visão de curto prazo, para solucionar problemas já agravados de imediato e, quando se pensava um planejamento de forma mais geral, que abrangesse toda a cidade (ou mesmo uma região), em curto, médio e longo prazo, quer na esfera nacional, quer na local, as ações neste sentido tendiam a ser desconsiderada, porque não atenderiam a contento os interesses da classe dominante.

O Estatuto da Cidade proporcionou um novo entendimento do Planejamento Urbano, de forma que é um instrumento passível de conseguir, a partir de uma árdua tarefa, a realização dos objetivos propostos. Constitui um desafio aos planejadores urbanos porque a Lei ainda permite impedimentos de ordem jurídica, cultural, histórica e política, além da dificuldade de articulação entre os diversos atores (tanto dos sociais como dos entes da federação). 
O Estatuto da Cidade é uma lei que contém instrumentos que podem ser muito úteis para auxiliar na transformação da triste realidade urbana que assola as cidades brasileiras, em especial as médias e as grandes, porém é fundamental que sejam observados os seus princípios, utilizados adequadamente os seus instrumentos e principalmente que se tornem ações concretas, não apenas discurso bem formulado. Desta forma esta Lei é um instrumento para o desenvolvimento e definição da ocupação dos municípios, além de prever a participação popular na gestão não só territorial, mas geral.

Para que seus objetivos sejam realmente alcançados, deverá ser modificada a maneira de se fazer planejamento urbano no Brasil, pois não se tem a tradição de ouvir a população e construir pactos a partir da apreciação das diversas alternativas, do embate entre os diversos interesses, o que representará uma imensa evolução. A população deverá ser preparada para seu novo papel no processo de planejamento e gestão das cidades, assim como os técnicos das diversas áreas envolvidas no processo urbano, os políticos e os diferentes grupos e representações populares. A obrigatoriedade da participação popular em todo o processo (desde o diagnóstico dos problemas, às formas de solução, até a fiscalização da implantação das ações, passando pela fiscalização dos recursos) é um grande avanço, embora seja uma construção lenta e nem um pouco fácil e tranqüila, mas poderá trazer inúmeros benefícios pára a população em geral.

O Plano Diretor foi eleito tanto pela Constituição de 1988, como pelo Estatuto da Cidade como protagonista das reformas, pois a ele toda a Legislação municipal deve se submeter. É a partir dele que se formatará a cidade, segundo a vontade democrática da população. Podemos constatar que: "A questão da participação popular, contudo acabou tendo um papel secundário em vista dos demais instrumentos de controle e desenvolvimento urbano, principalmente porque o Estatuto deu pouca ênfase aos conselhos de desenvolvimento urbano". SOUZA (2002), esta questão, ao lado da questão metropolitana, poderia ter sido mais bem tratada pelo Estatuto da Cidade, ou outra legislação de cunho federal.

O plano diretor participativo segundo o Estatuto da Cidade, não deverá ser como os das décadas anteriores, documentos cujas propostas eram impossíveis de se realizar, feitos por uma elite de técnicos em gabinetes, ou encomendados para cumprir uma formalidade legal ou ainda, para promover uma ideologia da classe dominante. Estes planos ou eram um amontoado de informações ou documentos vazios, sem aplicabilidade, que acabavam engavetados e desconhecidos da população. O plano 
diretor deverá ser uma lei amplamente conhecida, construída pela comunidade, e posteriormente por ela fiscalizada, na sua elaboração e revisão deve ser levada em consideração a realidade do município e as ações contempladas terem o poder de concretização.

Para tanto, não se poderá prescindir de se gerar e se manter um banco de dados atualizados para o município, pois o conhecimento amplo da cidade é uma determinante para que se possa proporcionar para todos uma visão geral e um conhecimento mais profundo do município. Também deve se investir num sistema tributário justo e atualizado, sem o qual não se terá a justiça social. Por fim, o preparo da população para que, a partir do conhecimento da realidade de sua cidade, possa participar de forma mais atuante é um ponto a ser amplamente trabalhado, quanto a isso é necessário que a prefeitura coloque todas as informações geradas a disposição de todos, pois o espaço urbano é constantemente alterado, sendo produto da atuação de diversos atores com diferentes desejos e pontos de vista. As informações devem ser socializadas, utilizandose inclusive dos sistemas mais modernos e eficazes para a divulgação, como a internet.

A questão da distribuição de receitas entre os entes da federação é outro problema sério a ser enfrentado. As prefeituras, a despeito de ser o poder mais próximo do povo e de ter tantas obrigações, fica com a menor parte dos tributos, 5\% da receita total arrecadada pelo Estado brasileiro.

Outro ponto a ser considerado é o desenvolvimento regional, pois o Estatuto cumpre perfeitamente seu papel enquanto instrumento para o desenvolvimento local, mas, em época de "globalização" não se pode desconsiderar questões regionais e nada foi previsto para as relações intermunicipais, de forma que ficou uma lacuna ao se desconsiderar por completo as questões regionais e (principalmente) metropolitanas. Sabe-se que $40 \%$ da população segundo CÂMARA DOS DEPUTADOS (2004) vivem em regiões metropolitanas ou aglomerados urbanos, e não se pode fechar os olhos para os problemas que decorem destas aglomerações, deixando tudo para ser resolvido a partir do diálogo e da boa vontade dos políticos, pois apear da negociação ser um bom meio, é moroso e não tem se mostrado de todo eficiente.

Apesar de existirem entraves, são muitos os progressos alcançados como a possibilidade de um controle espacial adequado á dinâmica das atividades, as novas possibilidades de ocupação e zoneamento, a preocupação com o meio ambiente, a possibilidade de diálogos entre os diversos grupos, o controle mais rigoroso das ações do poder público municipal pela população, a participação do povo no processo de 
planejamento e na gestão do município, entre outros, restando contar com o poder do Ministério Público, agindo como fiscal da Lei, não permita que o Estatuto da Cidade seja transformado em letra morta em municípios cujas administrações são arcaicas, conservadoras e autoritárias, frustrando o desejo da população que tanto batalhou pela mudança, ressaltando-se que poucas leis em nosso país foram construídas contanto esforço da população em geral e, portanto, possui tanta legitimidade.

Os planos diretores (e seus vários nomes e tipologias), apesar de corretos e cheios de boas intenções, só saíram do papel em raríssimos casos, e de forma geral, tem representado uma forma ideológica de conter às classes excluídas dos benefícios da urbanização e da cidade. Este novo modelo de plano diretor apresentado pelo Estatuto da Cidade não deverá ser o único instrumento de planejamento urbano a ser utilizado pelos municípios, e ainda assim, dependerá para surtir efeitos de várias outras questões como o a maneira como serão utilizados os instrumentos urbanísticos conforme as peculiaridades do município; do nível de participação (e cobrança) da população (incluindo a publicidade que se dará ao plano); da estrutura administrativa; do modo como o prefeito administrará a cidade, e da seriedade em se fiscalizar as ações.

No Brasil, assistiu-se na década de 1970 e 1980 o silêncio do Governo Federal quanto às questões relativas ao planejamento urbano (especialmente aquela que lhe cabe que são as questões que extrapolam o poder local). Com o advento da Constituição Federal de 1988, e posteriormente a promulgação do Estatuto da Cidade, ficou evidente que ao município é conferido grande poder de decidir seu destino, tendo em vista ser o nível adequado para se tratar de vários problemas que assolam a população urbana. $O$ Estatuto da cidade modificou a forma de se fazer planejamento urbano e também plano diretor.

O Estatuto da Cidade, e o plano diretor participativo, são esperanças concretas de mudanças, seus princípios e objetivos, se corretamente utilizados, poderão fortalecer os debates públicos, e as classes desfavorecidas, uma vez organizadas, terão maior força para reivindicar a justa distribuição das melhorias. Os técnicos, devem assumir também um novo papel, ao intermediar estes conflitos, apresentar caminhos, projetos, viabilidades e possibilidades de implementação das ações, sem se esquecer que as decisões finais estão no campo da política. Alias, será justamente na maneira como os governantes municipais enxergarão os apelos populares e suas carências, associado à forma com que seus problemas serão solucionados é morará o grande desafio, visto que 
apenas a legislação avançada, moderna, e bem intencionadas não conseguirão transformar em fatos concretos a letra da lei.

O Estatuto representa um grande avanço (e principalmente, uma grande esperança), mais ainda temos uma lacuna de grande importância para ser preenchida: $O$ planejamento urbano nas Regiões Metropolitanas e Aglomerados Urbanos. Como tem se apresentado atualmente, serão localidades cada vez mais difíceis para se viver, pois seus problemas comuns se apresentam de difícil solução devido a autonomia política de cada município, às disputas políticas entre eles, a falta de continuidade administrativa e, a falta de comprometimento dos gestores envolvidos. Vê-se que os pactos são frágeis, as ações demoram para serem construídas e implementadas. É preciso uma ordem mínima comum, estabelecida em legislação federal.

No Estado de Mato Grosso foi instituído o Aglomerado Urbano Cuiabá / Várzea Grande, porém, a falta de regras de ordem federal tem contribuído para fragilizar o planejamento urbano na localidade, tendo em vista a falta de interesse das prefeituras em estabelecer compromissos comuns, e não raramente, algumas áreas da gestão municipal buscam escapar até do diálogo.

São muitos os motivos que contribuem para a dificuldade de se planejar Regiões Metropolitanas e Aglomerados Urbanos (como acima foi citado), e no caso do Aglomerado Urbano Cuiabá / Várzea Grande, verifica-se empecilhos de toda a ordem como os que já foram escrito por CHILETTO (2005), como "a falta de estrutura (física, financeira e humana) da Secretaria Executiva, a falta de entrosamento entre as diversas Câmaras Setoriais, o despreparo de muitos camerários que são indicados apenas para cumprir um protocolo, os prefeitos que alegam proveitosa ignorância para não cumprir acordos, o desconhecimento das potencialidades do AGLURB, tanto por órgãos dos governos estaduais e municipais, como pela população e pela mídia”, enfim, vê-se claramente que não há um comprometimento político, e desta forma as ações que são propostas pelas Câmaras Setoriais não são levadas a diante, e consequentemente não se concretizam. A falta de resultados palpáveis leva desanimo aos técnicos, e desta forma, o esvaziamento de certas Câmeras.

Desta forma conclui-se que o Aglomerado Urbano foi uma instância que proporcionou o diálogo, mostrou-se apropriada para a instituição de algumas políticas comuns e elaboração de planos e projetos, mas mostro-se instância frágil para a execução das ações, devido a falta de recursos próprios e a ausência de poder para intervir fisicamente nos municípios. 
A história de Cuiabá e de Várzea Grande, pode explicar a formação de sua sociedade, com diferenças sociais muito grandes. Os ricos historicamente sempre foram muito ricos, e os pobres, dependentes destes para sobreviver, como acontece em outras localidades do país. Por aqui as leis sempre foram aplicadas segundo a interpretação e o interesse das classes dominantes (como no resto do Brasil). O dito "progresso" ainda é coisa recente em Cuiabá e Várzea Grande, e não faz muito tempo que os antigos políticos com práticas para lá de autoritárias deixaram o poder para que outras lideranças pudessem arejar um pouco a política local. Isto se deve muito às correntes migratório que tem desafiado antigas formas de se fazer política, e trazido novas idéias, mas não tem sido fácil modificar antigos hábitos que estão no cerne da cultura brasileira, e por isso são mais difíceis de serem mudadas.

Apesar de vizinhas, as cidades de Cuiabá e Várzea Grande são bem diferentes quando o assunto é estrutura administrativa. Cuiabá desde a década de 1980 já havia percebido que necessitava de uma estrutura adequada para tratar o planejamento urbano, e ainda que a política urbana e os problemas da cidade deveriam ser discutidos por todos, de forma contínua. Muitas melhorias na cidade têm se percebido desde então, e é inegável que a qualidade de vida tem melhorado sensivelmente. Claro que ainda há muito que se conquistar, porque existem problemas vividos por todas as cidades brasileiras que se vê também por aqui, mas verifica-se que o povo mais necessitado tem tido, ao menos, o direito de opinar e participar das questões relativas ao urbano, quer seja nas reuniões do plano diretor, do orçamento participativo ou nas conferências da cidade.

Já Várzea Grande, onde o continuísmo político reitera a formula antiga de se fazer política, a estrutura administrativa é ultrapassada e ineficiente. A necessidade de modernização é reconhecida inclusive no discurso dos políticos de todas as legendas, mas na prática, as mudanças tem sido lentas. Tudo isso se reflete no tecido urbano e nas condições de vida da população. Várzea Grande é carente de tudo, da água potável até áreas de lazer (não possui nenhum parque). A população, cansada de reclamar, acaba por buscar soluções por si mesmas (cavam poços, ou quem pode, manda fazer um poço artesiano, e o rio Cuiabá torna-se o único lazer das classes menos favorecidas). Contudo, a população tem pressionado (através das urnas) para que mudanças sejam providenciadas, e com as oportunidades promovidas pelo plano diretor participativo e também com o orçamento participativo, a tendência é que as mudanças sejam inevitáveis. 
Os desafios são imensos. As mudanças não acontecerão tão rapidamente, farão sim parte de um processo. Há de se reconhecer que o Brasil é desigual, e enquanto existem cidades cuja população possui uma cultura de participação e crítica em relação aos seus assuntos, outras ainda não possuem o hábito da participação e do debate, e, portanto, ainda não se organizaram para tanto. Sem a vigilância constante da sociedade organizada, os planos diretores certamente não terão eficácia, e continuarão a ser peças adormecidas em gavetas de repartições, por melhor e bem intencionadas que sejam as propostas da lei.

Tem se visto, ainda, que nas localidades onde a população é chamada para os debates sobre as questões urbanas, tem se obtido uma resposta positiva, o que demonstra a boa vontade da população em estar participando, e a necessidade de se propiciar condições para tanto. Nos municípios estudados ainda são modestas as instâncias as quais a população tem acesso à participação no processo de construção e principalmente na execução e fiscalização dos resultados das ações, mas a tendência é melhorar.

Os munícipes precisarão estar preparados para seu papel, o que requer medidas eficazes para levar conhecimento às diversas camadas sociais, e às diversas localidades. Também os técnicos e os políticos deverão estar preparados para enfrentar estes novos desafios de como lidar com a população numa relação de conflitos de interesses, disputas e divergências, como é o caso de Regiões Metropolitanas.

Como ainda não há uma política de planejamento conjunto para as regiões metropolitanas e aglomerados urbanos (e mesmo para as redes de cidades), os planos diretores podem ser conflitantes nestes locais, ficando a população a mercê de acordos, negociações e conversas intermináveis que demoram a surtir efeitos práticos, dependendo da boa convivência entre os vizinhos (e que nem sempre existe), ficou então esta lacuna no Estatuto da Cidade, que necessita ser solucionado pelo diálogo, por acordos, e boa vontade de todos os envolvidos.

O planejamento urbano continua sendo indispensável para o controle urbano do município, basta olhar como outros países se utilizam dele para construírem cidades melhores, e evitar que apenas parte de seus moradores sejam beneficiados. O plano diretor é uma etapa do planejamento, poderíamos dizer que é o ponto de partida para as demais ações, mas como ponto de partida, não pode ser desprezado, ainda que tenha que sofrer ajustes e ser aprimorado ao longo dos anos, mas é a base das demais ações, construída comunitariamente. O planejamento urbano deve ser contínuo, não apenas um 
momento de elaboração de plano, mas deve ser pensado, planejado, executado, monitorado, avaliado e reestruturado de maneira cíclica.

Cuiabá e Várzea Grande já possuíam planos diretores quando a Lei 10.257/01 Estatuto da Cidade - trouxe a obrigação da revisão, por conta dos "novos" instrumentos urbanísticos apresentados e, principalmente, devido aos seus princípios, especialmente a obrigatoriedade da participação popular no planejamento e na gestão urbana.

Contudo, a forma de implementação dos dois planos, diferenciou-se bastante. Observa-se que enquanto o poder público de Várzea Grande engavetou o seu plano diretor de 1994 e até mesmo, ignorou suas leis urbanísticas, Cuiabá buscou colocá-lo em prática, elaborando leis complementares e avançando em algumas questões, como por exemplo, o abairramento, que contou inclusive com a participação popular nas reuniões, isto fez muita diferença em termos de qualidade de vida da população (em especial a mais carente).

O diálogo entre as duas cidades vizinhas, já existia por conta de ações isoladas como as que fiscalizam a extração de areia e cascalho do Rio Cuiabá, e das freqüentes reuniões do Aglomerado Urbano que levantava e discutia problemas, potencialidades e soluções em diversas áreas. Porém, quando o Núcleo de Apoio aos Planos Diretores do Estado de Mato Grosso passou a preparar os municípios do Estado para a elaboração de seus Planos Diretores, pode-se verificar a desigualdade em termos de informação, experiência administrativa que se encontravam Cuiabá e Várzea Grande.

Apesar das circunstâncias, Várzea Grande contava com um Plano de Trabalho já aprovado junto ao Ministério das Cidades via Caixa Econômica Federal, que possibilitou a contratação de consultoria, e que fez toda a diferença para o município, e foi fundamental para o sucesso da elaboração do Plano Diretor Participativo de Várzea Grande, inclusive levantando as informações que o município possuía porem estava pulverizada em vários órgãos e por vezes dependendo até mesmo do relato pessoal dos funcionários. Quanto mais se possui informações sobre a cidade, melhor e mais específicos serão os planos e programas. Um banco de informações constantemente alimentado faz a diferença para que sejam realizadas as escolhas mais apropriadas no momento de estabelecer as prioridades das ações. Neste ponto, Várzea Grande se encontra fragilizada, pois poucas são as secretarias que alimentam e divulgam bancos de dados, colocando suas informações a disposição não apenas das demais secretarias mas da população de forma geral. Cuiabá já faz este trabalho (alimentar bancos de dados, 
organizá-los e divulgá-los, tanto pela internet, como em formato de livro) e isto é determinante para o planejamento da cidade.

Melhor preparada, Cuiabá encarou o desafio com o seu próprio corpo técnico, e apesar da forma diferenciada de promover a participação popular (com menos reuniões e com o corpo técnico em conjunto com a população, realizando quase que ao mesmo tempo a leitura técnica e a comunitária) não falhou na sua tarefa.

De forma geral, o Plano Diretor Estratégico de Cuiabá de 2006 mostrou-se bastante parecido com o anterior, de 1994. Já o Plano Diretor Participativo de Várzea Grande de 2007, diferenciou-se bastante do antecessor.

Quanto ao conteúdo, os dois planos se mostram corretos, enaltecem os direitos dos cidadãos a uma cidade mais justa na divisão dos ônus e dos benefícios, a democracia nos momentos de decisão, o controle pela população dos atos públicos, o diálogo com os demais vizinhos da região e a parceria nas políticas que visem o benefício geral do Aglomerado Urbano, entre outros princípios e discursos coerentes e justos. Na prática, porém, sabe-se que as coisas não são fáceis, e muitas das ações e das políticas propostas não se auto-aplicam, necessitando de várias leis, e contrariando inclusive o Estatuto da Cidade que apregoa a simplificação da legislação. Isto para que o munícipe não se confunda entre normas e mais normas que acabam sendo aplicadas com pesos, medidas e interpretações diversas, dependendo muitas vezes de interesses particulares dos envolvidos no processo. As transformações pretendidas dependem de estudos, leis, recursos financeiros, reestruturação administrativa e vontade política para reverter problemas que se originaram na forma de ocupação do território (espalhada e desarticulada) e descaso com o controle urbanístico, especialmente a fiscalização do cumprimento às normas já existentes, assim as prefeituras tem buscado a hierarquização das ações, mas ainda não ficaram claro quais as prioridades e nem a forma de monitoramento e de avaliação. No caso de Cuiabá, o plano diz que as ações serão a curto, médio e longo prazo, mas poucas diretrizes no plano realmente estabelecem o que será executado em cada período. Várzea Grande fez este estudo na leitura comunitária, mas acabou não levando mito adiante, pois a população pedia tudo para curto prazo, e o pior é que realmente eram ações que não podiam esperar. Como se pode dizer que será levado água regularmente para uma localidade populosa em médio ou longo prazo? Ou que o transporte coletivo só melhorará em longo prazo? Ou que o córrego que em tempos de cheia invadem as residências só será limpo em médio prazo? Na prática, as 
pessoas querem o asfalto, o transporte, a água, a limpeza urbana e o saneamento no mais curto prazo possível.

Pode-se concluir que a estrutura administrativa faz a diferença para que os resultados positivos sejam conquistados em tempo menor, neste ponto, Várzea Grande tem muito para avançar, e Cuiabá, deverá ajustar o que necessita ser melhorado devendo as duas cidades entrarem em sintonia com os princípios que regem o serviço público, e estarem abertas para projetos que envolvam as duas cidades, e também Santo Antônio de Leverger e Nossa Senhora do Livramento, integrantes da Região Metropolitana.

Observa-se que tanto o plano diretor de Cuiabá quanto o de Várzea Grande foram construídos, seguindo a maioria dos princípios e orientações do Estatuto da Cidade, especialmente quanto a participação da população, colocaram em seus textos os instrumentos para controle urbanístico, buscaram o diálogo e a cooperação entre as duas cidades que faziam parte do aglomerado (atualmente da Região Metropolitana), tanto na elaboração como se buscou deixar claro a intenção de contribuir nas políticas e ações em nível metropolitano. Contudo, muitas questões fundamentais foram tratadas de forma superficial, tanto por Cuiabá como por Várzea Grande, como no caso da regulamentação dos instrumentos urbanísticos, onde ambas as cidades apenas os colocam nos seus planos, e deixam - salvo raras exceções - quase tudo para ser resolvido em "leis específicas" que deverão conter as particularidades para tornar efetiva e eficaz a utilização dos instrumentos e desta forma realizar o controle urbanístico das respectivas cidades.

Desta forma os planos de Cuiabá e Várzea Grande - e especialmente os instrumentos urbanísticos - não são auto-aplicáveis, e tanto um como o outro plano necessitam de uma série de outros planos setoriais, como os de habitação, para conhecer melhor e desenvolver ações de acordo para cada setor. Cuiabá já realizou seu plano de Transporte e Trânsito, Várzea Grande não, o Plano de Cuiabá não prevê as ligações com Várzea Grande, o que ficará para outro momento. As duas cidades preparam seus planos de habitação.

Um problema sério tanto para Cuiabá como para Várzea Grande são os vazios urbanos, e os planos trataram do problema sendo que Cuiabá estabeleceu um período (dez anos) para que o perímetro pudesse ser aumentado, Várzea Grande definiu seu perímetro abraçando os loteamentos já existentes e com ocupação mínima, no entanto, já se tem notícias que será revisto por conta de alguns loteamentos que ficaram fora do 
perímetro. Então não se pode saber se outros interesses particulares de grupos influentes serão capazes de alterar a Lei do Plano Diretor dos Municípios.

O estabelecimento de ZEIS, de grandes áreas para serem adensadas e a criação do Órgão para habitação e regularização fundiária, em Várzea Grande facilitará a realização das ações neste setor (especialmente o Plano de Habitação). Em Cuiabá, onde já existe a Agencia de Habitação, será necessário incrementar as ações já existentes e executar o Plano de Habitação, inclusive com a disponibilidade de melhores estruturas para a Agência e com a regulamentação dos instrumentos urbanísticos e a revisão da legislação (como vem ocorrendo).

Cuiabá já está administrativamente relativamente bem estruturada, Várzea Grande, como manda o Plano Diretor, vem se estruturando e se reorganizando administrativamente, a utilização de mapas e sistemas georeferenciados tanto para o controle urbanístico, como para a cobrança de impostos trará maior segurança para os processos, justiça no valor apurado e facilidade. Cuiabá também está refazendo sua planta genérica de valores se utilizando da mesma tecnologia. Nas duas cidades, a LOA o PPA e demais meios de planejamento financeiro são elaborados de forma participativa, mas a fiscalização destas ações (voltadas para o planejamento financeiro), como elas estão sendo executadas, ainda é um ponto de interrogação, apenas a publicação de forma pouco atrativa, complicada para o cidadão comum e sem a divulgação adequada torna se insuficiente para se dizer que existe participação da população na gestão municipal, tendo em vista que falta o controle durante o processo.

Para o acompanhamento do Plano Diretor de Várzea Grande, foi instituído o Conselho da Cidade e foi um paço muito importante para o debate em torno das questões físicas da cidade, não está como foi observado, livre de intenções políticas, mas não deixa de ser um canal democrático para o debate, e tem cumprido bem o seu papel, com reuniões semanais e discussões profundas sobre as questões apresentadas. $\mathrm{O}$ Conselho para os mesmos assuntos em Cuiabá já estava instituído anteriormente ao Plano Diretor ser aprovado, mas a pergunta que fica sem resposta, para ambas as cidades, é como o povo será informado do que se tem debatido nestes espaços. A população não têm tido acesso de forma fácil à pauta, aos debates e em às atas das reuniões. Isto em tempos de internet é fácil de ser resolvido, basta um canal e divulgação, para que as pessoas interessadas possam saber o que está acontecendo.

Quanto aos assuntos discutidos a nível metropolitano, é necessário que os assuntos e ações propostas sejam realmente executados de forma conjunta e não apenas 
se tenha um discurso de ações integradas e na prática, cada um faz os planos e as obras do seu lado do rio e depois se vê como é que se irão juntar os projetos. Com a possibilidade dos consórcios e dos convênios, é fácil a colaboração mútua para melhores resultados. De forma geral os Planos não apresentaram divergências o que facilita a integração do planejamento. É clara a intenção (ainda que contida) de se buscar soluções em conjunto para os problemas comuns.

Outros temas relacionados ao assunto deste trabalho e de grande importância para a região poderão ser investigados. Sugere-se estudos referentes a formação e implantação da Região Metropolitana do Vale do Rio Cuiabá; a questão da habitação de interesse social em Cuiabá e Várzea Grande (especialmente a implantação dos Planos de Habitação); acessibilidade e mobilidade urbana em Cuiabá e Várzea Grande (ou na Região Metropolitana recém formada); de forma mais profunda poderão ser realizados estudos sobre a administração pública das cidades em questão e os planos, as ações e mudanças urbana pós Planos Diretores.

Respondendo as questões formuladas, concluímos que nos Planos Diretores elaborados pelos Municípios adotaram os princípios e os instrumentos do Estatuto de Cuiabá e Várzea Grande foram elaborados seguindo os Princípios e objetivos do Estatuto da Cidade, de forma harmônica, tendo em vista que nenhuma diretriz dos planos se contrapõe e sendo municípios conurbados nos planos aparece a intenção de diálogo e de planejar o que for preciso em comum.

Os Planos Diretores foram elaborados levando em conta a realidade das cidades, tendo em vista o volume de pesquisas realizadas, especialmente no município de Várzea Grande, as diversas reuniões com a comunidade e a equipe técnica das cidades.

Podemos observar que os Planos estão sendo implementados, sendo que o estágio atual corresponde à elaboração de planos setoriais, leis e projetos, pois verificou-se que os planos não são autoaplicáveis devido a estas necessidades.

Finalizando, a elaboração dos Planos Diretores de forma participativa foram experiências positivas para Cuiabá e Várzea Grande, pois, permitiu além do diálogo entre as cidades, estreitando os laços e a abertura de canais para o planejamento integrado. As cidades têm buscado seguir o que os Planos determinam, e atendendo ao Estatuto da Cidade, pode-se notar que a participação popular tem sido positiva para a modernização e democratização da gestão urbana. É evidente que só o Plano Diretor não será suficiente para melhorar os problemas, longe disso, mas se trata de mais um instrumento para o planejamento urbano que não podemos abrir mão, e aliado aos 
demais instrumentos de planejamento, ao conhecimento da cidade (informações constantemente atualizadas), a uma administração moderna, eficiente e bem preparada, e a vontade política, e acima de tudo, compreender que o planejamento é uma atividade contínua e dinâmica, se poderá melhorar a vida dos cidadãos de Cuiabá e Várzea Grande.

\section{2- BIBLIOGRAFIA}

ANPUR. - Ética, Planejamento e Construção Democrática do Espaço. Anais - Vol. 1. IX encontro nacional da ANPRU. Rio de Janeiro, 2001.

ANPUR - STEINBERGER, MARÍLIA. O Significado da Região Centro-Oeste na Espacialidade do Desenvolvimento Brasileiro: Uma análise geopolítica. Em GONÇALVES, MARIA FLORA, BRANDÃO, CARLOS ANTÔNIO. GALVÃO, ANTÔNIO CARLOS, organizadores. Regiões e Cidades, Cidades nas Regiões. O desafio Urbano-Regional. São Paulo, Editora Unesp, 2003.

ARANTES, O.- Uma estratégia fatal. A cultura nas novas gestões urbanas. In ARANTES, O. VAINER, C. MARICATO, E.- A cidade do pensamento único. Desmanchando consensos. $2^{\text {a }}$ edição. Petrópolis. Editora Vozes. 2002.

ARRIGHI, GIOVANI - O longo século XX, UNESP Editora, 1996.

BASTOS, CELSO RIBEIRO - Curso de Direito constitucional. $17^{\text {a }}$ ed. São Paulo, Ed. Saraiva, 1996.

BASSUL, J.R.- Estatuto da Cidade - Quem ganhou? Quem perdeu? Brasília - DF: Senado Federal, 2005.

BORGES, ANA CAROLINA DA SILVA; KRAMER, TIAGO; PEREIRA, SUELI CASTRO - Representações sobre o ambiente natural e a relação sociedade e natureza no pantanal. Estudo apresentado no IV Simpósio sobre Recursos Naturais e Sócio-econômicos do Pantanal. Corumbá - MS. 2004. 
BORJAS, JORDI. CASTELLS, MANUEL. - Local y Global; la gestión de la ciudads em la era de la información. Madri, habitat/Taurus, 1997.

BRASIL. - Constituição Federal de1988

BRASIL. Lei 10.257, de 10 de julho de 2001. Estatuto da Cidade.

BRASIL. Ministério das Cidades - Plano Diretor Participativo: Guia para elaboração pelos Municípios e cidadãos. $2^{\mathrm{a}}$ edição / Coordenação Geral de Raquel Rolnik e Otilie Macedo Pinheiro - Brasília: Ministério das Cidades, Confea, 2005. IBGE. Em www.ibge.org.br . Visitado em 22-08-2006

CAMPOS FILHO, CANDIDO MALTA - Cidades Brasileiras: Seu Controle ou o Caos. O que os Cidadãos devem fazer para a Humanização das cidades no Brasil. São Paulo: Studio Nobel, 1992.

CAMPOS FILHO, CÂNDIDO MALTA - Reinvente seu bairro, São Paulo, Editora 34, 2003.

CARNOY, MARTIN - Estado e Teoria Política, Ed. Papirus, 1989.

CASTELLS, MANUEL - A era da informação econômica, sociedade e cultura, São Paulo, Ed. Paz e Terra, 1999, $3^{\circ}$ vol.

CASTELlS, MANUEL - A intervenção Administrativa nos Grandes Centros Urbanos, in Espaços \& Debates no 6, p. 64.

CASTELLS, MANUEL. - La Ciudad informacional. Madri. Aliança editorial. 1995.

CASTELLS, MANUEL - A questão Urbana, Ed. Paz e Terra, Rio de Janeiro, 1983.

CASTRO, M. I.- Natureza e Sociedade em Mato Grosso (1850-1930). Tese de Doutorado pela UBCDS, Brasília, 2001. 
CHILETTO, R. C. O.- Avaliação do Estatuto da Cidade como Promotor do Reordenamento Territorial no Aglomerado Urbano Cuiabá/Várzea grande-MT. Dissertação de mestrado apresentada à Universidade Federal de Mato Grosso, 2005.

CHOAY, FRANÇOISE - O urbanismo - Utopia e Realidade, Uma Antologia, Editora Perspectiva, São Paulo, 1979.

CHAUÍ, MARILENA - O que é ideologia, São Paulo, Ed. Brasiliense.

COMPANS, ROSE. - Os Limites da ação Pública Local. In ANPUR. Ética, Planejamento e Construção Democrática do Espaço. Anais - Vol. 1. IX encontro nacional da ANPRU. Rio de Janeiro, 2001.

CUIABÁ, PREFEITURA MUNICIPAL. - Instituto de Pesquisa e Desenvolvimento Urbano. Perfil Socioeconômico de Cuiabá, Vol. II. Cuiabá. Central de Textos, 2004.

CUIABÁ - Lei Complementar nº 004/97, que instituiu o Código Sanitário de Defesa do Meio Ambiente e Recursos Naturais;

CUIABÁ - Lei de Uso e Ocupação do Solo e Parcelamento do Solo Urbano;

CUIABÁ - Lei 2.021, de 1982, que disciplina o parcelamento do solo urbano

CUIABÁ - Lei 3.870 de 05 de julho de 1999 (hierarquização viária);

CUIABÁ - Lei 103 de 05 de dezembro de 2003;

CUIABÁ - Lei 044, de 23 de dezembro de 1997

CUIABÁ - Lei Complementar nº 003 de 24 de dezembro de 1992

CUIABÁ - Lei Complementar nº 007 de 27 de agosto de 1993

CUIABÁ - Lei Complementar nº 004 de 24 de dezembro de 1992 
CUIABÁ - Lei Complementar nº 102 de 03 de dezembro de 1993

CUIABÁ - Lei Complementar $n^{\circ}$ 108/03, que estabelece critérios técnicos para elaboração e implementação dos projetos de habitação popular de interesse social, entre outras Leis que fazem parte do arcabouço jurídico da prefeitura.

CUIABÀ - Lei Complementar nº 150/2007

DAVIDOVICH, F. - Metrópole e contemporaneidade, algumas pontuações. In: Lemos, A. I. G.; Carlos A. (orgs.) Dilemas Urbanos: Nova abordagem sobre a cidade. São Paulo: Contexto, 2003.

DEÁK, C. e SCHIFFER, S. - O processo de urbanização no Brasil. São Paulo: EDUSP/FUPAM, 1999.

DEÁK, CSABA - Globalização ou Crise Global ? In: SCHIFFER, SUELI (org.) Globalização e Estrutura Urbana. São Paulo, Ed. HUCITEC, 2004.

DIAS, M. L.- Notas sobre o direito urbanístico: “A cidade sustentável”. Revista Jus Navigandi, Teresina -PI, a.5, $\mathrm{n}^{\mathrm{o}}$ 47, nov. 2000. In www1.jus.com.br. acesso em22/06/2004.

FRANCO, AUGUSTO DE. - Desenvolvimento Local integrado e Sustentável: dez consensos in HADDAD, FERNANDO (org.). Desorganizando o consenso: nove entrevistas com intelectuais à esquerda. São Paulo/Petrópolis. Editora fundação Perseu Abramo/Vozes. 1998.

IBGE. - Em www.ibge.org.br . Visitado em 22-08-2006

FERNANDES, E. Um Novo estatuto para as Cidades Brasileiras. In OSÒRIO, L. M. (Org). Estatuto da Cidade e Reforma Urbana: novas perspectives para as cidades brasileiras. Porto Alegre: Sergio Antônio Fabris, 2002. 
FOLHA DO ESTADO - Comércio de Cuiabá ganha nova cara. Pág. 17. Cuiabá, 0807-2007.

FRENTE NACIONAL DE PREFEITOS - O Desafio da Gestão das Regiões Metropolitanas em Países Federativos, -, Brasília, 2005.

GRAZIA, G. - Reforma Urbana e Estatuto da Cidade. In: RIBEIRO, L. C. Q; CARDOSO, A.L. (Org). Reforma Urbana e Gestão Democrática: Promessas e Desafios do Estatuto da Cidade. Rio de Janeiro: Revan, 2003.

GOTTIDIENER, MARK - A Produção Social do Espaço Urbano, EDUSP, São Paulo, 1993.

HALL, PETER - Cidades do Amanhã, São Paulo, Perspectiva, 1995.

HARVEY, DAVID - Condição pós-moderna, uma Pesquisa sobre as origens da mudança Cultural, Ed. Loyola, 1993.

HARVEY, DAVID - O Trabalho, o Capital e o Conflito de Classes em Torno do Ambiente Construído nas Sociedades Capitalistas Avançadas, in Espaço \& Debates $n^{\circ} 6$, junho - setembro de 1982, p.6.

HARVEY, DAVID - A Justiça Social e a Cidade, Ed. Hucitec, 1980.

HARVEY, DAVID - Do gerenciamento ao empresariamento: a transformação da administração urbana no capitalismo tardio, São Paulo, Espaço \& Debates, Ano XVI, 1996, no 39. p. 48 - 64.

LEFEBVRE, HENRI - O direito à cidade. São Paulo. Editora Morales, 1991.

LEME, MARIA CRISTINA DA SILVA (cood.) - Urbanismo no Brasil 1895 - 1965, São Paulo, Ed. Nobel, FAU / USP / FUPAM 1999. 
LIPIETZ, A. - Le national et le regional: quelle autonomie face à la crise capitaliste mondiale? In BENKO, G. (ed.) - La Dynamique Spatiale de L'Économie Conemporaine. Éditions de L’Espace Européen. Colombes. 1990.

LODDER, CELSIUS A. - O processo de Crescimento Urbano no Brasil. Rio de janeiro, Revista de Planejamento Econômico, 1977. in TOLEDO, ANA HELENA P. de. CAVALCANTI, MARLY (orgs.) - Planejamento Urbano em Debate. São Paulo, ed. Cortez \& Moraes, 1978.

MALUF, SAHID - Teoria geral do Estado, São Paulo, Ed. Saraiva, $21^{\text {a }}$ edição, 1991.

MARICATO, ERMÍNIA -. Brasil, cidades. Alternativa para a crise urbana. $2^{\text {a }}$ edição. Petrópolis. Editora Vozes, 2002.

MARICATO, ERMINIA. - As idéias fora do lugar e o lugar fora das idéias. in ARANTES, O. VAINER, C. MARICATO, E. - A cidade do pensamento único. Desmanchando consensos. $2^{\mathrm{a}}$ edição. Petrópolis. Editora Vozes. 2002.

MARICATO, ERMÍNIA. 1994. - Reforma Urbana: Limites e Possibilidades. Uma trajetória incompleta. In RIBEIRO, LUIZ CÉZAR Q. \& SANTOS JR, ORLANDO A. dos. (orgs.). Globalização Fragmentação e Reforma Urbana. Rio de Janeiro, Civilização Brasileira. 1994.

MATO GROSSO, SEPLAN - Anuário Estatístico de Mato Grosso - 2004. Vol. 26. / Secretaria de Estado de Planejamento e Coordenação Geral. - Cuiabá: SEPLAN-MT: Central de Texto, 2005.

MATO GROSSO - Lei Complementar nº 359 de 27 de maio de 2009.

MEIRELES, HELY LOPES - Direito Municipal Brasileiro, $6^{\text {a }}$ edição, São Paulo, Malheiros Editores, 1993.

MORI, KLARA KAISER, - A ideologia na construção do espaço brasileiro. Em DEÁK, CSABA, SCHIFFER, SUELI, (orgs). O processo de urbanização no Brasil, São Paulo. Editora da Universidade de São Paulo, 2004. 
Motta, AleXANDRE RiBEIRO. PORTO, PAUlo C. DE SÁ.- Porto Alegre Análise das Políticas Urbanas Recentes. In ANPUR. Ética, Planejamento e Construção Democrática do Espaço. Anais - Vol. 1. IX encontro nacional da ANPRU. Rio de Janeiro, 2001.

NAMUR, MARLY - Estado e Empresariado em Curitiba. A formação da Cidade Industrial. 1973-1980. Tese de Doutorado em Estruturas ambientais Urbanas da FAUUSP, 1992.

NEVES, JOSÉ LUIS - Pesquisa Qualitativa - características, usos e possibilidades,Caderno de Pesquisas em Administração, São Paulo, V.1, №3,2 ${ }^{\circ}$ sem./1996. Capturado no site www.ead.fea.usp.br em 11-08-2006.

OLIVEIRA, ISABEL CRISTINA EIRAS DE - Estatuto da Cidade; para compreender... Rio de Janeiro: IBAM/DUMA, 2001.

PEREIRA, BRESSER - Desenvolvimento e Crise no Brasil, Ed. 34, 2003.

POÉTE, MARCEL - A cidade como organismo vivo. Em CHOAY, FRANÇOISE. O urbanismo: Utopias e Realidades, uma Antologia. São Paulo, Ed. Perspectiva, $4^{\text {a }}$ edição. 1997.

PRADO JR. CAIO. - História Econômica do Brasil. São Paulo, ed. Brasiliense, 1986.

PREFEITURA MUNICIPAL DE CUIABÀ. www.cuiaba.mt.gov.br visitado em 2-052007.

PORTELA, G. L. - Abordagens teórico-metodológicas. Projeto de Pesquisa no ensino de Letras para o Curso de Formação de Professores da UEFS. Capturado no site www.uefs.br, em 11-08-2006.

PREFEITURA MUNICIPAL DE VÁRZEA GRANDE.- $\underline{\text { www.cuiaba.mt.gov.br }}$ visitado em 20-08-2006. 
PREFEITURA MUNICIPAL DE VÁRZEA GRANDE.- www.varzeagrande.mt.gov.br Visitado em 22-08-2006.

Rede de Avaliação e Capacitação para a implementação dos Planos Diretores Participativos - Pré proposta de roteiro para Avaliação dos Planos Diretores. No site www.cidades.gov.br. Visitado em 18/12/2008.

REIS FILHO, NESTOR GOULART - Urbanização e Teoria. Tese para provimento de Cátedra. São Paulo: FAU / USP, 1967.

Reordenamento Territorial no Aglomerado Urbano Cuiabá/Várzea Grande-MT. Dissertação de mestrado apresentada à Universidade Federal de Mato Grosso, 2005.

RIBEIRO, ANA CLARA T. DIAS, LEILA CHRISTINA.- Escalas de poder e novas formas de gestão urbana e regional. In ANPUR. Ética, Planejamento e Construção Democrática do Espaço. Anais - Vol. 1. IX encontro nacional da ANPRU. Rio de Janeiro, 2001.

RIBEIRO, HELENA, VARGAS, HELIANA COMIN, (ORGS) - Novos Instrumentos de Gestão Ambiental Urbana, São Paulo: Editora da Universidade de São Paulo, 2001.

RODRIGUES, A. M. - Gestão da Região metropolitana e da Metrópole: possibilidades e limites de gestão compartilhada. In: Seminário Internacional Geografia - Demografias da Metrópole - A Metrópole do Século XXI. São Paulo: 2004. In CHILETTO, R. C. O.- Avaliação do Estatuto da Cidade como Promotor do

ROLNIK, R. - A cidade e a Lei: legislação, política urbana e território na cidade de São Paulo. São Paulo. Studio Nobel Fapesp, 1997.

ROLNIK, R.; SOMEKH, N. - Governar as Metrópoles: dilemas da recentralização. In : RIBEIRO, L. C. de Q. - Entre a Coesão e a fragmentação, a Cooperação e o Conflito, $1^{\text {a }}$ ed. São Paulo: Fundação Perseu Abramo/FASE/Observatório das Metrópoles, 2004. In: CHILETTO, R. C. O.- Avaliação do Estatuto da Cidade como 
Promotor do Reordenamento Territorial no Aglomerado Urbano Cuiabá/Várzea grande-MT. Dissertação de mestrado apresentada à Universidade Federal de Mato Grosso, 2005.

ROMANCINI, SONIA REGINA - Cuiabá: Paisagens e espaços da memória. Cuiabá. Cathedral Publicações, 2005.

ROSA, C. A. A - Vila Real do Bom Jesus de Cuiabá. Tese de Doutorado pela FFLCH/USP, São Paulo, 1996.

SANTOS, M. - A natureza do espaço. Técnica, razão e emoção. São Paulo: Hucitec, 1996.

SANTOS, M. - A revolução das Cidades. Em www.midianews.com.br em 12/10/2008

SANTOS, M. - O Espaço Dividido. 2a ed., São Paulo: Ed. Edusp, 2004.

SANTOS, M. - O Espetáculo das Cidades. Em www.midianews.com.br em $12 / 10 / 2008$

SANTOS, M. - Técnica, Espaço, Tempo: Globalização e Meio Técnico Científico Informacional. $4^{\text {a }}$ ed. São Paulo: Hucitec, 1998.

SASSEN, S. - Globalização da Economia e as Cidades. In: SCHIFFER, SUELI (org.) - Globalização e Estrutura Urbana. São Paulo, Ed. HUCITEC, 2004.

SCHIFFER, SUELI (org.) - Globalização e Estrutura Urbana. São Paulo, Ed. HUCITEC, 2004.

SCHIMIT, BENÍCIO VIEIRO - O Estado e a Política no Brasil, Editora da Universidade e L\&M Editores, Porto Alegre, 1983.

SEGUNDO, R. - O Planejamento Urbano Frente ao Estatuto da Cidade. Em www. estatutodacidade.com.br. em 23/09/2008. 
SERRA, GERALDO - O Espaço e a Forma Urbana, São Paulo, Ed. Nobel, 1987.

SERRA, GERALDO - Urbanismo e centralismo Autoritário. Tese de Livre Docência FAU - USP, 1987.

SILVA, JOSÉ AFONSO DA, - Curso de Direito Constitucional Positivo, 20 a edição, São Paulo, Malheiros Editores, 2001.

SILVA, J. B da - Estatuto da Cidade versus Estatuto da Cidade - eis a questão. In: Carlos, A. F. A.; Lemos, A. I. G. (Org.). Dilemas urbanos: novas abordagens sobre a cidade. São Paulo, Contexto, 2003.

SPOSITO, M. E. B. - Capitalismo e Urbanização. 10ª ed. São Paulo: Contexto, 1994.

SIQUEIRA, E.M - A ocupação pioneira da região do rio Cuiabá abaixo. Cuiabá MT. Instituto Histórico e geográfico de Mato Grosso. 1997. (publicações avulsas, ${ }^{\circ}$ $01)$.

SOJA, EDWARDW - Geografias Pós-modernas. Rio de Janeiro, Zahar Editora, 1993.

SOUZA, ARTEMEA PEREIRA DE - A questão urbana e ambiental do Distrito Industrial de Cuiabá. Monografia de conclusão do curso de Geografia da Universidade Federal de Mato Grosso - UFMT. Cuiabá, 2000.

SOUZA, MARIA ADELAIDE A. DE - O II PND e a política urbana brasileira: Uma contradição evidente. Em DEÁK, CSABA, SCHIFFER, SUELI, (orgs). O processo de urbanização no Brasil, São Paulo. Editora da Universidade de São Paulo, 2004

SOUZA, M. L. - O desafio Metropolitano: Um Estudo sobre a Problemática Sócioespacial das Metrópoles Brasileiras. $2^{\mathrm{a}}$ ed. Rio de Janeiro: Bertrand Brasil, 2002. 
TOLEDO, ANA HELENA P. de. CAVALCANTI, MARLY (orgs.). - Planejamento Urbano em Debate. São Paulo, ed. Cortez \& Moraes, 1978.

TOLOSA, HAMILTON C. - Política Urbana e Redistribuição de Renda. Rio de Janeiro. Revista de Planejamento Econômico em 07/04/1977. in TOLEDO, ANA HELENA P. de. CAVAlCANTI, MARLY (orgs.). - Planejamento Urbano em Debate. São Paulo, ed. Cortez \& Moraes, 1978.

TOPALOV, CHRISTIAN - La Urbanización Capitalista, México Edicol, 1970.

VAINER, CARLOS BERNARDO. - As Escalas do Poder e o Poder das Escalas: O Que Pode o Poder Local? in ANPUR. Ética, Planejamento e Construção Democrática do Espaço. Anais - Vol. 1. IX encontro nacional da ANPRU. Rio de Janeiro, 2001.

VARGAS, HELIANA COMIN - Comércio: Localização estratégica ou estratégia na Localização. São Paulo, Editora SENAC, 2001.

VARZEA GRANDE - Lei nº 3.112/2007

VARZEA GRANDE - Lei nº 1.266/1992

VARZEA GRANDE - Regimento interno do Conselho da Cidade de Várzea Grande, Várzea Grande 2009.

VERTRAG - Plano Diretor Participativo de Várzea Grande: 2007 - 2017, volume 1. Fase1: Plano de Trabalho e Metodologia; Fase: 2: Leitura Comunitária da cidade e do território. Várzea Grande, 2007

VERTRAG - Plano Diretor Participativo de Várzea Grande: 2007 - 2017, volume 2. Fase3:Avaliação Temática Integrada; Fase: 4:Síntese das Leituras Técnica e Comunitária. Várzea Grande, 2007 
VERTRAG - Plano Diretor Participativo de Várzea Grande: 2007 - 2017, volume

3. Fase 5: Proposições e Eixos Temáticos. Várzea Grande, 2007

VILAÇA, FLAVIO - Espaço Intra Urbano no Brasil. São Paulo, Studio Nobel: FAPESP: Lincoln Institute, 1998.

VILLAÇA, FLAVIO - Uma contribuição para a história do planejamento urbano no Brasil. In DEÀK, CSABA, SCHIFFER. SUELI R. (orgs.) - O processo de urbanização no Brasil. São Paulo, Edusp, 1999.

XAVIER, HELIA NACIF - Desafios da Nova Política Urbana, Rio de Janeiro. Ed. IBAM, 2005. 
